UNIVERSIDADE DE SÃO PAULO

FACULDADE DE FILOSOFIA, LETRAS E CIÊNCIAS HUMANAS

NÚCLEO DE ESTUDOS DAS DIVERSIDADES, INTOLERÂNCIAS E CONFLITOS PROGRAMA DE PÓS-GRADUAÇÃO HUMANIDADES, DIREITOS E OUTRAS LEGITIMIDADES.

Cássia Milena Nunes Oliveira

\title{
Diálogos socioambientais na RESEX Taquari e RDS Itapanhapima - Cananeia/SP
}

São Paulo 
UNIVERSIDADE DE SÃO PAULO

FACULDADE DE FILOSOFIA, LETRAS E CIÊNCIAS HUMANAS

NÚCLEO DE ESTUDOS DAS DIVERSIDADES, INTOLERÂNCIAS E CONFLITOS

PROGRAMA DE PÓS-GRADUAÇÃO HUMANIDADES, DIREITOS E OUTRAS LEGITIMIDADES.

\section{Diálogos socioambientais na RESEX Taquari e RDS Itapanhapima - Cananeia/SP}

Cássia Milena Nunes Oliveira

Tese de doutorado apresentada ao Programa de Pós-Graduação Humanidades, Direitos e Outras Legitimidades para obtenção do título de Doutor em Humanidades sob orientação da Prof. Dr. Zilda Márcia Grícoli Iokoi.

De acordo 
Autorizo a reprodução e divulgação total ou parcial deste trabalho, por qualquer meio convencional ou eletrônico, para fins de estudo e pesquisa, desde que citada a fonte. Catalogação da Publicação.

Catalogação na Publicação

Serviço de Biblioteca e Documentação

Faculdade de Filosofia, Letras e Ciências Humanas da Universidade de São Paulo

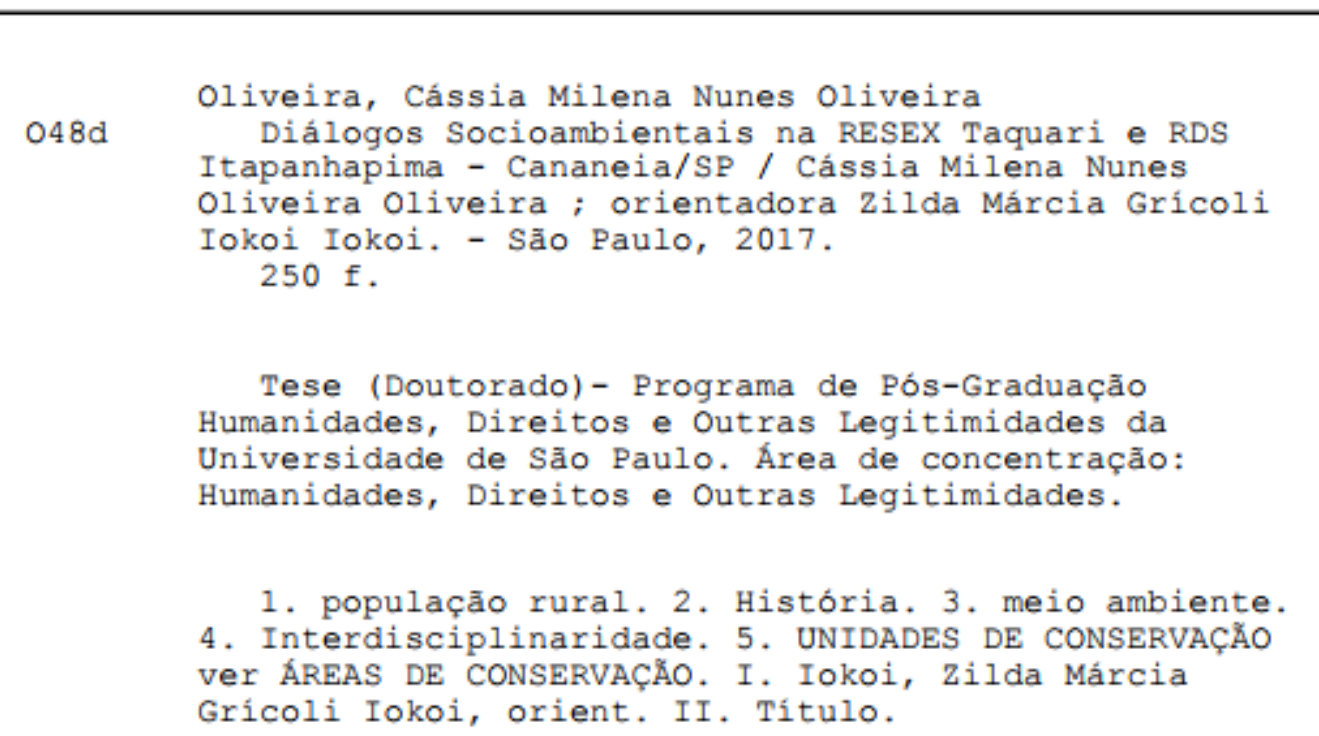


Nome: Cássia Milena Nunes Oliveira

Título: Diálogos socioambientais na RESEX Taquari e Itapanhapima-Cananeia-SP

Tese apresentada à Faculdade de Filosofia, Letras e Ciências Humanas da Universidade de São Paulo para obtenção do título de Doutor em Humanidades

Aprovado em:

Banca Examinadora:

Prof. Dr.

Instituição:

Julgamento: Assinatura:

Prof. Dr. Instituição:

Julgamento: Assinatura:

Prof. Dr. Instituição:

Julgamento: Assinatura:

Prof. Dr. Instituição:

Julgamento: Assinatura: 
A todos aqueles que das mais variadas formas lutam por reforma agrária no mundo. 


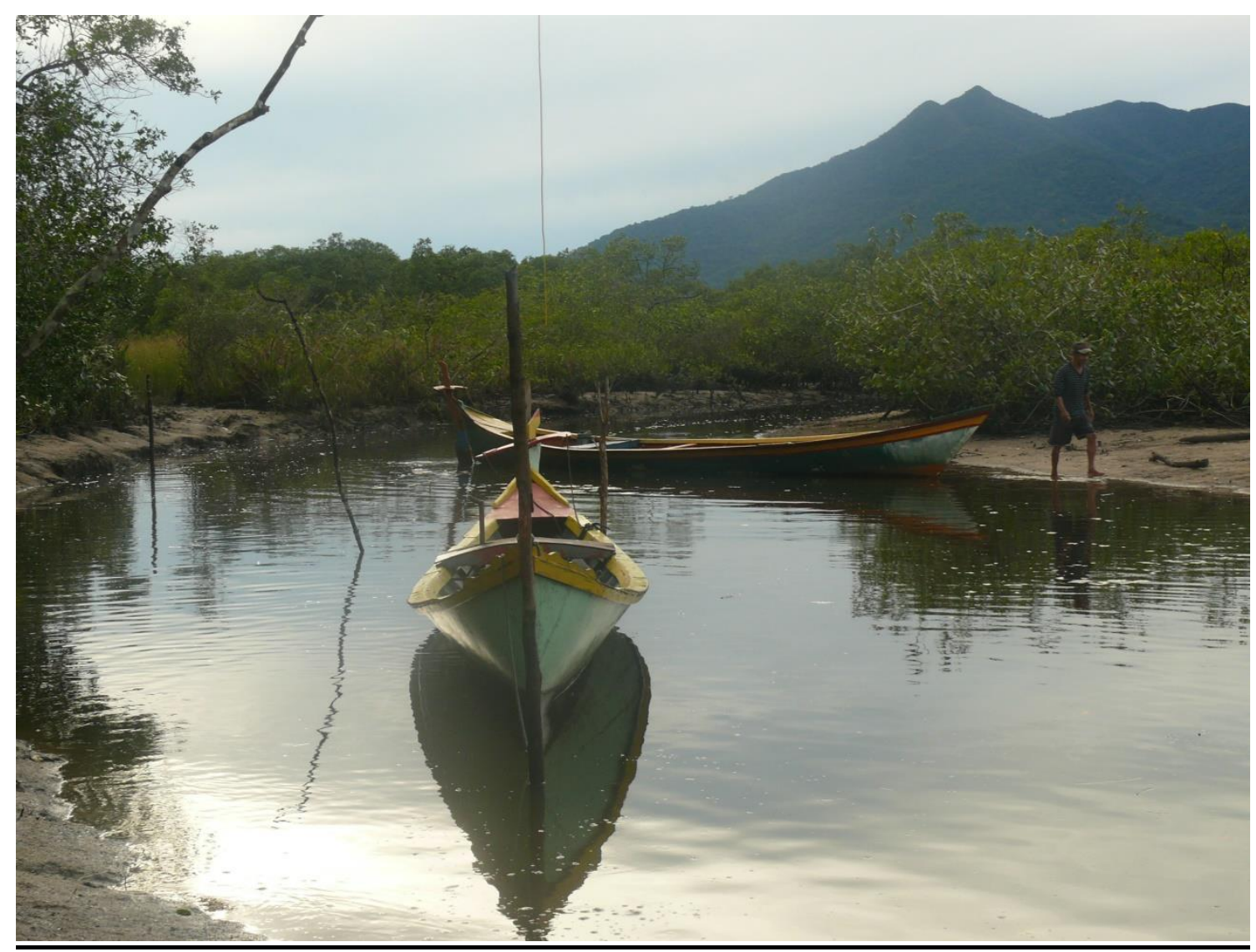

Porto da comunidade do Retiro/RDS Itapanhapima. 


\section{Agradecimentos}

Todo trabalho de pesquisa é uma caminhada que nos dispusemos a realizar. Essa caminhada traz aprendizados, alegrias, decepções, mudanças de rota, presentes e perdas. De todo o vivido, reafirma-se uma certeza: a necessidade de agradecer. Sem dúvida esse trabalho não teria se realizado sem a grande rede de apoio com a qual sempre pude contar. Sobretudo nos momentos de maior dificuldade, foi ela que me fez forte. Diante disso, fico imensamente feliz em poder agradecer à minha família, pessoas incríveis que sempre me acolhem, apoiam, respeitam e assim me ajudam a ser quem sou: minhas irmãs Alessandra e Mayra, meu pai Nelson e sobretudo minha mãe Therezinha, que não mede esforços para contribuir com nossas escolhas, ainda que elas nem sempre se demonstrem corretas.

À minha orientadora Prof. Dra. Zilda Márcia Grícoli Iokoi, pela rica convivência, apoio e aprendizado.

À Coordenação de Aperfeiçoamento de Pessoal de Nível Superior que financiou o projeto de pesquisa.

Aos meus companheiros e companheiras de vida: Fabio, meu amor e parceiro cotidiano; Rogê Carnaval, camarada de vida; Paulo Salvetti, pelo amor e revisão do texto; Jonas Santana, que tantas vezes me acolheu em Cananeia e um dos presentes dessa jornada; Lia Kayano, que sempre acreditou em meus projetos de vida e minha capacidade de realizá-los.

Aos amigos, amigas, professores e funcionários do Núcleo de Estudos das Diversidades, Intolerâncias e Conflitos, em especial aos docentes Luís Guilherme Galeão da Silva e Maria das Graças Souza, pelas contribuições e apoio.

Aos amigos de Piedade, rancho tranquilo que me dá sempre a certeza de que tenho para onde voltar.

Aos amigos e amigas de São Paulo que me ensinaram a gostar dessa cidade.

Aos amigos e amigas de Cananeia, cidade bela e gentil que me encantou por sua gente e história. Em especial à amiga Beth Conti e aos funcionários da Fundação Florestal.

Aos mestres Álvaro Ramos e Edélcio Tenório, meus sempre professores de História.

Ao samba. 
Aos colaboradores de pesquisa que me permitiram conhecer suas histórias, entrar em suas casas, seus locais de trabalho, seus espaços de luta política. E principalmente, por reafirmarem minha convicção de que resistir pelo que acreditamos é digno e necessário. Ao Padre João 30, a quem não conheci pessoalmente, mas cuja história de vida me encantou. Obrigado por dedicar sua vida à luta por aqueles que o poder e a ganância tentaram apagar da História. 


\section{Resumo}

A Reserva de Desenvolvimento Sustentável (RDS) Itapanhapima e a Reserva Extrativista (RESEX) Taquari foram criadas na cidade de Cananeia, área litorânea do Vale do Ribeira no estado de São Paulo, como parte das Unidades de Conservação (UC’s's) de uso sustentável que compõem o Mosaico de Unidades de Conservação do Jacupiranga (MOJAC), criado em 2008. Essas novas categorias de unidade de conservação de uso sustentável foram formuladas no âmbito dos debates que envolveram o Sistema Nacional de Unidades de Conservação (SNUC), a partir de uma visão socioambiental, ou seja, que busca aliar conservação da biodiversidade e da sociodiversidade. Dessa forma, a proposta do MOJAC tem como objetivo aliar proteção ambiental ao desenvolvimento sustentável, e permitir a permanência digna das populações reconhecidas como tradicionais em seus territórios de direito.

A partir disso, este trabalho de pesquisa analisa o processo de implementação dessas novas categorias de unidades de conservação ambiental na área rural da cidade de Cananeia e os novos conflitos decorrentes dessa forma de intervenção governamental em áreas historicamente ocupadas. Tal análise foi feita sob a perspectiva das populações locais que, a partir desse contexto, passam a ser reconhecidas jurídica e politicamente como tradicionais. Para tanto foi elaborado um corpus documental por meio do registro das histórias de vida dos beneficiários destas unidades de conservação, segundo os procedimentos técnicos e analíticos da história oral.

Palavra-chave: populações - tradicionais - conflito - ambiental - interdisciplinaridade história oral. 


\section{Abstract}

The Itapanhapima Sustainable Development Reserve (RDS) and the Taquari Extractive Reserve (RESEX) were created in the city of Cananeia, a coastal area of the Ribeira Valley in the state of São Paulo, as part of the Sustainable Conservation Units (UC's) from a sustainable use which composes the Jacupiranga Conservation Units Mosaic (MOJAC) created in 2008. These new categories of conservation units for sustainable use were formulated in the context of the debates that involved the National System of Units Conservation (SNUC) from a socio-environmental perspective, that is, it seeks to combine biodiversity and socio diversity preservation. Therefore, the proposal of MOJAC aims to ally environmental protection to sustainable development and allow a worthy and dignified permanence for the populations recognized as traditional in their territories by rights.

From this, this research work analyzes the implementation process of these new environmental units conservation categories in the rural area of the city of Cananeia and the new resulting conflicts from this form of governmental intervention in historically occupied areas. This analysis was done from the perspective of local populations that, from this context, are now legally and politically recognized as traditional. For this, a documentary corpus was elaborated through the recording of life histories of the beneficiaries of these conservation units, according to the technical and analytical procedures of oral history.

Key words: populations - traditional - conflict - environmental - interdisciplinary - oral history. 


\section{SUMÁRIO}

$\begin{array}{ll}\text { Introdução - O percurso do projeto } & 11\end{array}$

Capítulo 1 - A História Oral e o encontro com o vivido 21

1.1 Procedimentos em História Oral 23

Capítulo 2 - Cananeia: Território e resistência. 36

2.1 As comunidades, um padre e a luta por direitos 57

Capítulo 3 - O socioambientalismo: Uma resposta institucional aos $\quad 70$ conflitos?

3.1 Populações Tradicionais: Reconhecimento jurídico-político e Unidades

89 de Conservação

3.2 Reserva Extrativista Taquari

3.3 Reserva de Desenvolvimento Sustentável Itapanhapima 161

3.4 Unidades de Conservação Sustentáveis: Construção autoritária e conflitos.

Capítulo 4 - Unidades de Conservação e a reinvenção do cotidiano.

4.1 O caminho das ostras 213

4.2 A RESEX Taquari e a agricultura: Antigos caminhos para novos 234 caminhos.

$\begin{array}{ll}\text { Considerações finais } & 238\end{array}$

$\begin{array}{ll}\text { Bibliografia } & 241\end{array}$

$\begin{array}{ll}\text { Sites consultados } & 248\end{array}$ 


\section{Introdução - O Percurso do projeto}

Este trabalho de pesquisa intitulado Diálogos socioambientais na RESEX Taquari e RDS Itapanhapima-Cananeia/SP foi acolhido como um dos projetos importantes realizados no programa interdisciplinar "Humanidades, Direitos e outras Legitimidades", sob orientação da Prof. Dr. Zilda Márcia Grícoli Iokoi.

A ideia do projeto se desenvolveu a partir do contato com a cidade de Cananeia, litoral sul do Estado de São Paulo. A aproximação com o cotidiano e as histórias dos moradores locais permitiu uma maior percepção dos conflitos que envolveram o processo de criação das unidades de conservação e as populações locais, cujo meio de vida se entrelaça fortemente ao território que ocupam. Essas histórias eram sempre permeadas pelo autoritarismo do Estado que, durante o processo de criação da unidade de conservação do Parque Estadual da Ilha do Cardoso em 1962, expulsou diversas famílias que ocupavam intensamente seu lado norte, região relativamente próxima ao núcleo urbano situado na ilha Cananeia ${ }^{1}$. Esse primeiro contato com a problemática que envolve o conflito entre populações locais e a imposição de uma legislação ambiental de cunho preservacionista $^{2}$, estimulou a busca por uma melhor compreensão sobre a questão, por meio do histórico da criação das unidades de conservação no Brasil, em especial no Vale do Ribeira - SP. A bibliografia pertinente ao tema demonstrou que a legislação em torno da demarcação e regulação de territórios passíveis de conservação ambiental havia se transformado, e que atualmente existiam categorias de unidades de conservação elaboradas de forma a reconhecer a presença de populações locais, como as das Reservas Extrativistas e as das Reservas de Desenvolvimento Sustentável. Além disso, os moradores, que antes eram simplesmente expulsos de seus territórios, agora poderiam ser reconhecidos jurídica e politicamente como "populações tradicionais", detentores do direito de permanência e manejo controlado dos recursos naturais. Esse novo contexto legislativo caracteriza-se, portanto, pela emergência do socioambientalismo, ou seja, por uma perspectiva de conservação ambiental que busca promover a integração entre a proteção da biodiversidade e da sociodiversidade, envolvendo o amplo leque de

\footnotetext{
${ }^{1}$ A cidade de Cananeia possui uma vasta área continental banhada pelo estuário marítimo lagunar. Esse estuário separa a área continental da ilha de Cananeia, onde se encontra o núcleo urbano do munícipio.

${ }^{2}$ Sobre a questão da ideologia preservacionista e sua influência sobre o processo de formação das unidades de conservação no Brasil ver: DIEGUES, Antônio Carlos Sant'Ana, O Mito Moderno da Natureza Intocada. 6ed. ampliada. São Paulo: Hucitec, 2008.
} 
populações tradicionais brasileiras ${ }^{3}$. A partir disso, elaborei uma proposta de pesquisa com o intuito de analisar o processo de implementação das unidades de conservação sustentáveis na cidade de Cananeia, sob a perspectiva dos moradores das áreas demarcadas, utilizando como metodologia de trabalho o registro de histórias de vida segundo pressupostos da História Oral. Dessa forma, a pesquisa se realizou em duas Unidades de Conservação (UC's) de uso sustentável que foram sobrepostas a territórios historicamente ocupados por populações locais e, a partir disso, reconhecidas juridicamente como tradicionais ${ }^{4}$, mais especificamente como caiçaras ${ }^{5}$. Trata-se da Reserva Extrativista Taquari (RESEX Taquari), que tem como beneficiários ${ }^{6}$ os moradores da área de reserva sobreposta ao bairro Cantagalo-continente e inclui também aqueles que ficaram no entorno da unidade de conservação, como os do bairro Taquari e os da Colônia Santa Maria, e a Reserva de Desenvolvimento Sustentável Itapanhapima, que foi sobreposta aos bairros Retiro e Bom Bicho, sendo os beneficiários apenas os detentores de áreas para trabalho ou moradia no interior da reserva. Ambas se localizam na área rural e continental pertencente ao munícipio de Cananeia, sul do Estado de São Paulo, áreas que compõem a parte litorânea do Vale do Ribeira, região situada entre os estados de São Paulo e Paraná, e compreendem uma rica biodiversidade natural, aliada a baixos índices de desenvolvimento humano. ${ }^{7}$

Essas reservas sustentáveis puderam ser criadas no contexto nacional de surgimento de políticas voltadas para a proteção da diversidade socioambiental, expressas pelo reconhecimento jurídico e político dos direitos das chamadas populações tradicionais aplicados à legislação ambiental, como o Sistema Nacional de Unidades de Conservação $(\text { SNUC, 2000) })^{8}$ e a Política Nacional de Desenvolvimento Sustentável dos Povos e Comunidades Tradicionais (PNPCT, 2007) ${ }^{9}$. No contexto local, essas unidades constituem parte do Mosaico de Unidades de Conservação do Jacupiranga (MOJAC,

\footnotetext{
${ }^{3}$ SANTILLI, Juliana. Socioambientalismo e novos direitos. Proteção jurídica à diversidade biológica e cultural. São Paulo: Peirópolis, 2005.

${ }^{4}$.SANTILLI, op.citp. 123.

${ }^{5}$ MARCÍlIO, Maria Luiza. Caiçara, Terra e população. 2ed. São Paulo: EDUSP, 2006.

${ }^{6}$ Categoria genérica que envolve três situações que foram reconhecidas como detentoras do direito de manejo controlado da área: Os moradores das unidades de conservação de uso sustentável no caso da RDS Itapanhapima e RESEX Taquari, as populações do entorno da RESEX Taquari e os pescadores artesanais de Cananeia que também possuem o direito de utilizar a área para pesca.

${ }^{7}$ TAYRA, Flavio. Subdesenvolvimento e Sustentabilidade: o caso do Vale do Ribeira (SP). http://www.registro.unesp.br/sites/museu/basededados/arquivos/00000307.pdf Acesso em janeiro/2017. ${ }^{8}$ http://www.planalto.gov.br/ccivil_03/leis/L9985.htm Acesso em fevereiro/2017. 9http://www.planalto.gov.br/ccivil_03/_ato2007-2010/2007/decreto/d6040.htm. Acesso em setembro/2016.
} 
2008) ${ }^{10}$. Segundo o SNUC, o Mosaico deve implementar uma estratégia de gestão integrada de diversas categorias de unidades de conservação quando próximas, justapostas ou sobrepostas territorialmente.

\begin{abstract}
Quando existir um conjunto de unidades de conservação de categorias diferentes ou não, próximas, justapostas ou sobrepostas, e outras áreas protegidas públicas ou privadas, constituindo um mosaico, a gestão do conjunto deverá ser feita de forma integrada e participativa, considerando-se os seus distintos objetivos de conservação, de forma a compatibilizar a presença da biodiversidade, a valorização da sociodiversidade e o desenvolvimento sustentável no contexto regional. ${ }^{11}$
\end{abstract}

A especificidade que envolve a criação do Mosaico do Jacupiranga no Vale do Ribeira foi o fato de que ele não se instituiu como uma nova forma de gestão integrada entre diferentes categorias de proteção já existentes, como previsto na lei, e sim como uma estratégia política que tinha como foco amenizar conflitos territoriais decorrentes da demarcação do Parque Estadual do Jacupiranga (PEJ) em $1969^{12}$. Segundo a legislação ambiental brasileira vigente no período, o PEJ foi criado como uma unidade de conservação de proteção integral, ou seja, não permite presença humana e manejo de recursos naturais, sobreposta a uma área intensamente povoada com cerca de 8.000 moradores distribuídos em mais de 30 bairros rurais ${ }^{13}$. Na cidade de Cananeia, o PEJ se sobrepôs a áreas inteiras ou parciais dos bairros do Mandira ${ }^{14}$, Rio das Minas, Porto do Varadouro, Ariri e Colônia de Santa Maria. Assim como ocorreu em todo o Vale do Ribeira, a aplicação da legislação ambiental de cunho restritivo para a ocupação humana contribuiu de forma determinante para a desorganização do modo de vida local e costumeiro ao proibir o direito de uso e exploração dos recursos naturais como as atividades agrícolas, extrativistas e de pesca. Como reação, sobretudo a partir dos anos de 1980 e 1990, populações de muitas áreas afetadas pelo PEJ no Vale do Ribeira mobilizaram-se em associações de bairros, sindicatos rurais e, apoiadas por diversos grupos como a Comissão Pastoral da Terra (CPT), organizada a partir da Diocese de Registro, passaram a exigir do governo do Estado de São Paulo a exclusão dos territórios ocupados da área do Parque Estadual do Jacupiranga. Tal exigência só se concretizou

\footnotetext{
${ }^{10}$ http://www.al.sp.gov.br/norma/?id=76411 Acesso em fevereiro/2017

${ }_{11}$ Capítulo IV, artigo 26. http://www.planalto.gov.br/ccivil_03/leis/L9985.htm Acesso em janeiro/2017.

${ }^{12}$ BIM, Ocimar José Batista. Mosaico do Jacupiranga - Vale do Ribeira. Conservação, conflitos e soluções socioambientais. Dissertação (mestrado). São Paulo: Faculdade de Filosofia, Letras e Ciências Humanas da Universidade de São Paulo, 2012.

${ }^{13}$ Idem, p. 83

${ }^{14}$ Comunidade quilombola atualmente reconhecida como Reserva Extrativista Federal do Mandira.
} 
após o processo de criação do Mosaico de Unidades de Conservação do Jacupiranga (MOJAC), que reclassificou as antigas áreas de proteção integral com a implementação de novas categorias de unidades de conservação, dentre elas as de uso sustentável. Além da cidade de Cananeia, o MOJAC abrange ainda os municípios de Barra do Turvo, Cajati, Eldorado, Jacupiranga e Iporanga, todos também no Vale do Ribeira - SP e possui catorze unidades de conservação (UC's). Dentre essas UC's, três são de uso integral, cujo objetivo principal é "preservar a natureza, sendo admitido apenas o uso indireto dos seus recursos naturais" ${ }^{\prime 15}$, e onze unidades de uso sustentável, ou seja, capazes de “compatibilizar a conservação da natureza com o uso sustentável de parcela dos seus recursos naturais" $"$.

Nesse sentido, a reclassificação e reorganização territorial proposta pela criação do Mosaico representa a tentativa de criar uma legislação socioambiental que busque integrar conservação do meio ambiente e da diversidade sociocultural, por meio de uma gestão integrada entre sociedade e Estado, visando assegurar:

(...) um contínuo ecológico de remanescentes florestais da Mata Atlântica, protegendo a fauna, a flora, os recursos hídricos e patrimônios espeleológico, histórico e cultural, bem como fornecer apoio às comunidades tradicionais residentes nas Unidades de Uso Sustentável, que concentram populações quilombolas, caiçaras, ribeirinhas e caboclas. ${ }^{17}$

A investigação teórica interdisciplinar foi pautada principalmente pela geografia, história, antropologia, biologia, direito e sociologia ambiental, ecologia humana, publicações de organizações não-governamentais e a núcleos interdisciplinares como o NUPAUB - Núcleo de Apoio à Pesquisa sobre Populações Humanas em Áreas Úmidas Brasileiras e do PROCAM - Programa de Pós-Graduação em Ciência Ambiental da Universidade de São Paulo, o NEPAM- Núcleo de Estudos e Pesquisas Ambientais da Universidade de Campinas e do Projeto Nova Cartografia Social na Amazônia (PNCSA) - criado em 2005 pela Universidade do Estado do Amazonas. A necessidade de tão vasta rede de conhecimentos evidencia a complexidade do tema e a disputa teórica que o envolve: são muitas as áreas disciplinares que apresentam a noção de conservação ambiental dada a relação homem-natureza que o especifica. A base teórica originou uma

\footnotetext{
${ }^{15}$ Capítulo III, artigo 7. http://www.planalto.gov.br/ccivil 03/leis/L9985.htm. Acesso em janeiro/2017.

${ }^{16}$ Idem

${ }^{17} \mathrm{http} / / / \mathrm{www} . a m b i e n t e . s p . g o v . b r / 2017 / 02 / 20 /$ mosaico-do-jacupiranga-mojac-completa-nove-anos/

Acesso em março/2017
} 
primeira premissa: no aspecto legislativo, o Mosaico de Unidades de Conservação do Jacupiranga e as unidades de conservação de uso sustentável, que parcialmente o compõe, representam um marco na luta pelo direito de permanência de populações rurais no Vale do Ribeira. Isso porque ao reconhecer os direitos das chamadas "populações tradicionais", criou-se um aparato jurídico com o intuito de amenizar os conflitos entre a necessidade de conservação ambiental e os direitos territoriais das populações locais ${ }^{18}$. Após essa primeira aproximação teórica, iniciaram-se os contatos com os beneficiários, o que foi possível no espaço institucionalizado a partir de 2010 pela Fundação Florestal ${ }^{19}$ para a realização da gestão compartilhada do território: a Assembleia do Conselho Deliberativo, que reúne os representantes das duas unidades de conservação, a Fundação Florestal, a polícia ambiental, o poder público municipal de Cananeia e de membros da sociedade civil como a organização não-governamental Rede Cananeia, bastante atuante juntos às comunidades caiçaras da cidade. Já no primeiro contato, ocorrido no início de 2013, foi possível perceber o clima de enfrentamento e tensão entre beneficiários e representantes públicos que envolviam as reuniões de gestão. Por meio da leitura das atas e de informações obtidas junto ao gestor Osmar Pontes, foi possível constatar que existia uma grande insatisfação por parte dos beneficiários em relação às normas exigidas. Segundo essas críticas, essas normas, mesmo modificadas, continuavam a inviabilizar o uso dos territórios tradicionais e as possibilidades de sobrevivência na área.

Para compreender tal postura dos moradores em relação às unidades de conservação de uso sustentável, realizamos o conjunto de procedimentos pertinentes à História Oral como forma de ouvir, conhecer e reconhecer o universo do outro. O processo de construção e análise da base documental, pautada pelas experiências de vida narradas, tornou-se o caminho epistemológico capaz de articular saberes e promover um diálogo teórico entre aspectos do campo jurídico regulatório e do campo político da emancipação social de luta por reconhecimento e pelo direito de existir ${ }^{20}$. Sob essa perspectiva, as entrevistas "seriam alternativas valiosas para grupos e situações não promotora de documentos convencionais ou silenciadas por sanções como censura, interdição ou outro procedimento de silenciamento". ${ }^{21}$ Mais especificamente, buscamos

\footnotetext{
${ }^{18}$ SANTILLI, op. Cit. 125

19 Órgão estadual responsável pela gestão das unidades de conservação no Estado de São Paulo.

${ }^{20}$ SANTOS, Boaventura de Sousa MENESES, Maria Paula. (Orgs.) Epistemologias do Sul. São Paulo: Editora Cortez, 2010.p.32

${ }^{21}$ MEIHY, José Carlos Sebe Bom, HOLANDA, Fabíola. História Oral como fazer, como pensar. São Paulo: Contexto, 2007. p.76.
} 
discutir as transformações da política institucional ambiental brasileira aplicadas aos territórios historicamente ocupados por populações locais e o impacto dessas transformações sobre os beneficiários das unidades de conservação RESEX Taquari e RDS Itapanhapima. As histórias de vida registradas nos permitiram a identificação de uma memória coletiva ${ }^{22}$ construída por vivências comuns. Essa memória, num primeiro momento, é marcada pela violência do Estado que, ao instituir as áreas de conservação ambiental, criminalizou as antigas práticas de sobrevivência econômica, sobretudo em relação à agricultura e ao extrativismo. Em um segundo momento, as narrativas apresentam também a identificação das críticas em relação às novas categorias de unidade de conservação sustentáveis nas quais foram incluídos como beneficiários. Dentre essas críticas, destacam-se as que dizem respeito à manutenção da forma autoritária como a legislação ambiental, mesmo a de cunho socioambiental, foi aplicada à região. Dessa forma, identificaram a reserva sustentável como uma continuidade, uma extensão das primeiras políticas ambientais, visto que a legislação manteve uma série de cobranças e restrições que já existiam, sem que houvesse uma contrapartida compatível por parte do Estado às populações locais.

A memória coletiva identificada indicou que duas ideias comuns se apresentavam como limites:

1- As restrições impostas pelas unidades de conservação foram responsáveis por promover, no passado, a desorganização do modo de vida tradicional, visto que impediram a continuidade e reprodução dos hábitos e costumes locais.

2- O reconhecimento jurídico e político das populações tradicionais e a criação das unidades de conservação sustentáveis promoveram avanços em relação aos direitos de permanência no território. Entretanto, tal legislação baseada na ideia de respeitar uma gestão compartilhada do território de forma a viabilizar o desenvolvimento sustentável, não pôde, naquele momento, garantir condições efetivas para que esse desenvolvimento ocorresse.

Desenvolvemos, nesta tese, um caminho de análise orientado pela preocupação em demonstrar a perspectiva dos colaboradores em relação às questões apresentadas pela memória coletiva. Para tanto, recorremos ao método proposto por Henri Lefebvre para

\footnotetext{
${ }^{22}$ HALBWACHS, Maurice. A Memória Coletiva. São Paulo: Centauro, 2006.
} 
análise da realidade rural: descritivo, analítico-regressivo e histórico-genético ${ }^{23}$. Partimos, portanto, da observação respaldada pela bibliografia interdisciplinar, que contempla o desenvolvimento da legislação ambiental brasileira, sobretudo no que diz respeito ao surgimento das unidades de conservação e o reconhecimento jurídico e político das populações tradicionais. Após a construção do corpus documental por meio da História Oral, foi possível a análise das experiências narradas pelos sujeitos com o intuito de identificar a historicidade e a permanência dos conflitos que marcam esses territórios tradicionais. E, num terceiro movimento, reencontramos o presente com o intuito de apontar caminhos para a formulação de propostas que contemplem as especificidades de cada território. Por meio de uma outra história contada por aqueles que são tradicionalmente silenciados pelas instituições, pretendo contribuir com a crítica aos modelos formulados e impostos pelo Estado Brasileiro que impedem o desenvolvimento de novos processos produtivos capazes de aliar conservação ambiental e o desenvolvimento social das populações locais, de forma a garantir sua permanência no território. Compreendi, portanto, que sem o conhecimento da realidade local, dificilmente pode-se gestar novas possibilidades que de fato levem em conta as demandas das populações locais e do ecossistema, o que deveria ser o objetivo das políticas públicas de orientação socioambiental. Esta tese se divide, portanto, em quatro capítulos:

O primeira apresenta a trajetória de pesquisa e a abordagem teórica e metodológica que permeou o trabalho, com especial ênfase ao papel da história oral para a construção de outras histórias e novos olhares sobre o tempo presente, mais especificamente pela linha teórica praticada pelo Núcleo de Estudos em História Oral, que foi criada por José Carlos Sebe Bom Meihy.

O segundo capítulo tem como objetivo demonstrar alguns dos obstáculos centrais à permanência dos moradores em suas posses. Por meio das entrevistas realizadas com os colaboradores $^{24}$ deste trabalho, foi possível uma maior compreensão sobre o histórico de conflitos e resistências que se impõem como uma das características marcantes da região e da memória coletiva produzida naquela realidade e circunstâncias. Dentre os principais conflitos, destacam-se:

\footnotetext{
${ }^{23}$ LEFEBVRE, Henri. Perspectivas da sociologia rural. In: MARTINS, José de Souza (org.), Introdução Crítica à Sociologia Rural. 2ed. São Paulo: Hucitec, 1986, p.173.

24 "O entrevistador e o entrevistado, na situação de entrevista, devem se reconhecer como colaboradores. Porque a participação é espontânea, as duas partes devem manter uma possibilidade confortável para o estabelecimento da entrevista.” MEIHY, p. 20/21.
} 
- A violência agrária decorrente, sobretudo, da ação de grileiros ${ }^{25}$;

- A repressão decorrente da legislação ambiental implementada, sobretudo entre os anos de 1970 e 1980, e que afetou a manutenção das tradicionais estruturas produtivas agrícolas, extrativistas e de pesca.

O propósito analítico de retomar a historicidade da luta pela permanência nos territórios é compreender o contexto histórico local em que se deu a origem dos conflitos entre a legislação ambiental e as populações rurais de Cananeia. Essa segunda parte do trabalho é apresentada por meio da narrativa de Maria Aparecida Rangel, mais conhecida como Cida Rangel, auxiliar do padre de origem holandesa Jan Van Der Heijden, popularmente conhecido como Padre João 30. O trabalho de memória realizado por Cida Rangel retrata sua militância e a de Padre João junto às populações rurais e urbanas da cidade. Contribuindo de diversas formas para a organização das comunidades locais, sua experiência de vida permite uma maior compreensão do histórico de transformações econômicas e sociais que contextualiza historicamente o processo de organização da resistência dos moradores locais, contra a invasão de suas terras por grileiros e as restrições impostas pela demarcação de unidades de conservação de cunho preservacionista e a legislação ambiental. Sua narrativa permite, portanto, uma maior aproximação em relação às dificuldades vividas pelos nossos colaboradores e às estratégias de permanência por eles construídas para superar tais adversidades sociais e políticas.

O terceiro capítulo se preocupa com a caracterização das áreas propostas para o estudo. Partindo da noção de territorialidade, identificada por Little como um esforço coletivo de um grupo social para ocupar, usar, controlar e se identificar com uma parcela específica de seu ambiente biofísico ${ }^{26}$, procuramos demonstrar os principais problemas de gestão identificados pelos moradores que, segundo eles, impedem a reprodução de aspectos tradicionais ligados à sua territorialidade. Intentamos com isso contribuir para a elaboração de uma crítica ao modelo socioambiental aplicado aos territórios tradicionais,

\footnotetext{
${ }^{25} \mathrm{http}: / /$ www.incra.gov.br/oqueegrilagem Acesso em dezembro/2015.

É a ocupação irregular de terras, a partir de fraude e falsificação de títulos de propriedade. O termo tem origem no antigo artifício de se colocar documentos novos em uma caixa com grilos, fazendo com que os papéis ficassem amarelados (em função dos dejetos dos insetos) e roídos, conferindo-lhes, assim, aspecto mais antigo, semelhante a um documento original. A grilagem é um dos mais poderosos instrumentos de domínio e concentração fundiária no meio rural brasileiro.

${ }^{26}$ LITTLE, Paul. Territórios sociais e povos tradicionais no Brasil: por uma antropologia da territorialidade. Série Antropologia nº 322, p.32. Brasília: UnB, 2002.
} 
enfatizando a ideia de que a homogeneidade das leis que norteiam a gestão dos territórios não foi capaz de abarcar as demandas específicas locais. Assim, existe um descompasso entre a legislação atual de cunho socioambiental aplicada às populações tradicionais e sua realidade efetiva. Diante disso, formulamos algumas questões norteadoras para a pesquisa:

- Como se deu o processo de reconhecimento jurídico como população tradicional e a implementação das unidades de conservação sustentáveis sob a perspectiva dos beneficiários? Eles se identificam como de fato "beneficiários" do projeto implementado pelo Estado em seus territórios?

- Essa nova legislação busca estabelecer a ideia de gestão compartilhada do território como forma de diálogo entre instituição e populações tradicionais. Como esses beneficiários, agora reconhecidos como sujeitos políticos, percebem a nova realidade institucional na qual foram inseridos?

- Quais avanços e críticas são elaborados pelos sujeitos históricos em relação ao modelo de gestão?

Dessa forma, pretendemos analisar aspectos da visão construída pelos colaboradores sobre a reserva sustentável, os problemas comuns e os anseios particulares que envolvem os beneficiários das unidades de conservação. Para tanto, apresentamos as histórias de vida de alguns dos colaboradores desse trabalho.

\section{Beneficiários da RESEX Taquari:}

Noêmia Garcia da Silva - Antiga moradora do bairro Taquari. Possui casa na cidade, onde permanecia a maior parte do tempo no momento em que realizamos a entrevista.

Carlos França e Ivone França - Moradores do bairro Colônia Santa Maria que faz divisa com o Parque Lagamar onde se realizou a entrevista. Não possuem casa na cidade. 


\section{Beneficiários da RDS Itapanhapima:}

Gentil Pereira Davi e Isabel Pontes - Não possuem casa na cidade. Eram moradores do bairro Retiro, mas mudaram-se para uma área mais afastada para trabalhar como caseiros de uma fazenda. Essa fazenda foi desapropriada pela criação da unidade de conservação e eles permaneceram no local. Entrevista realizada na unidade de conservação.

Armando Pereira Davi e Dirce Pontes - Moradores do bairro Retiro. Possuem casa na cidade em processo de construção, mas passam a maior parte do tempo no sítio localizado na unidade de Conservação. Entrevista realizada na unidade de conservação.

No quarto capítulo pretendo demonstrar, apesar dos entraves políticos e jurídicos, quais iniciativas têm sido criadas pelos moradores a fim de recriar as formas de uso e exploração de suas áreas frente ao novo contexto legislativo. Dessa forma, buscamos apresentar propostas e demandas vistas pelos beneficiários como possibilidades para o estabelecimento de um sistema produtivo que gere renda para as famílias e viabilize a manutenção dos territórios tradicionais. Para responder a essas questões, escolhemos as narrativas de:

Adelmo Pontes Davi - Possui casa na cidade que constitui sua principal moradia. Após a criação das unidades de conservação em questão, foi contratado de forma terceirizada pela Fundação Florestal como guarda-parque do Parque Estadual Ilha do Cardoso. Entrevista realizada na cidade de Cananeia.

Bertolina Penache (Dona Tuca) - Moradora do bairro Colônia Santa Maria onde se realizou a entrevista. Não possui casa na cidade. Entrevista realizada em sua casa no sítio. 


\section{1- A História Oral e o encontro com o vivido.}

Esta pesquisa, desde o primeiro momento, surgiu da oralidade. Foi sentada à beira do Lagamar, em Cananeia, que ouvi a história do senhor Romeu Mario Rodrigues. Antigo morador da Ilha do Cardoso, ele e sua família foram expulsos de seus territórios com a criação do Parque Estadual da Ilha do Cardoso (1962). Ameaçados e perseguidos por agentes do Estado, migraram para a cidade de Cananeia, onde reinventaram seu cotidiano, ou seja, seu modo de vida, sua identidade e sua cultura. Já adulto e casado, prestou concurso público e se tornou guarda do mesmo parque que anos atrás os expulsara: "Eu tive que prestar concurso para voltar para minha casa". Essa e muitas outras histórias ouvidas na cidade de Cananeia, na Ilha do Cardoso e em outras comunidades como o Quilombo do Mandira, propiciaram um primeiro contato com os conflitos existentes entre a noção de conservação expressa pela legislação ambiental e os direitos das populações tradicionais.

Ainda que o amadurecimento da ideia inicial sobre o tema tenha alterado o local e o aspecto legislativo que seria investigado - no caso, a legislação socioambiental aplicada às unidades de conservação de uso sustentável -, não se alterou o propósito de ouvir e compreender as histórias daqueles que vivenciaram tais transformações, o que seria possível pelo caminho procedimental e reflexivo proposto pela história oral.

$\mathrm{Na}$ atualidade, o termo história oral se encontra amplamente difundido e reconhecido pelos círculos acadêmicos tradicionais ${ }^{27}$. No entanto, apesar de sua grande difusão, segundo Thompson, o uso da expressão é tão novo quanto o próprio gravador ${ }^{28}$, dado que, apesar do recurso à oralidade como fonte ser uma prática antiga dos historiadores, seu uso vinculado a um conjunto organizado de procedimentos, utilizandose de meios eletrônicos, remete-se à iniciativa de Allan Nevins que, em 1948, na Universidade de Columbia, instituiu-a como uma prática moderna de documentação histórica $^{29}$. Difundida sobretudo após a Segunda Guerra Mundial, a História Oral reflete o surgimento de questionamentos em relação às tradicionais fontes históricas, o que, aliado à difusão de meios modernos de registros como o gravador, propiciou a ampliação

\footnotetext{
27 JOUTARD, Philippe. Desafios à História Oral do século XXI. In: FERREIRA, Marieta de Moraes (org.). História Oral: desafios para o século XXI. Rio de Janeiro: Editora Fiocruz/Casa de Oswaldo Cruz/CPDOC - Fundação Getúlio Vargas: 2000. p.31.

${ }^{28}$ THOMPSON, Paul. A Voz do Passado: história oral. Rio de Janeiro: Paz e Terra, 1992.

${ }^{29}$ Idem, p.89.
} 
da prática de produzir narrativas a partir do exercício da memória. Mesmo que, inicialmente, essa primeira experiência e muitas outras que se seguiram estivessem vinculadas ao registro de personalidades notórias, ela inaugura a perspectiva de que experiências de vida pudessem ser utilizadas como fonte, como matéria-prima para a história. Cabendo aos historiadores a possibilidade de escolher quem e sobre o que perguntar, essa nova dimensão da História permitiu o surgimento de muitos trabalhos preocupados em trazer à tona sujeitos antes silenciados pela hegemonia dos grandes e relevantes personagens históricos.

No Brasil, um dos marcos para a introdução da História Oral se dá a partir dos anos de 1970, momento em que se destaca a iniciativa do Programa de História Oral do CPDOC da Fundação Getúlio Vargas ${ }^{30}$. Mas é sobretudo durante os anos de 1990 que ela passa a ser parte de programas de pós-graduação em História e promover maiores debates e intercâmbios entre pesquisadores, tanto internamente, quanto em outros países, o que contribuiu de forma significativa para o seu amadurecimento e seu reconhecimento como importante área do conhecimento ${ }^{31}$. Dentre as iniciativas desse período, podemos citar o surgimento da Associação Brasileira de História Oral e do Núcleo de Estudos em História Oral na Universidade de São Paulo. Segundo Meihy, um dos aspectos para compreender tal expansão se deve, dentre outros fatores, ao contexto político brasileiro vivido no período: o fim do regime militar. Isso porque o advento da democracia permitiu a emergência de diversos sujeitos até então silenciados. Ampliaram-se os debates em torno da oralidade e os espaços destinados à arte de contar e narrar o vivido, fato expresso pelo surgimento de iniciativas vinculadas a museus, arquivos ou grupos locais, mas principalmente à academia. No tocante a esta última, um importante fator destacado para a compreensão da "adesão brasileira às práticas da história oral é a insatisfação reinante nos círculos acadêmicos que não mais se comprazem com os resultados anteriores "32, fazendo com que a perspectiva aberta pelo registro da memória se tornasse uma forma de trazer à tona conhecimentos até então pouco acessíveis. Inicialmente associada à prática de entrevistas, foi frequentemente resumida como um meio técnico para a obtenção de dados de informantes, sendo muitos os seus "usos" por partes de diversas disciplinas. Dessa forma, o termo "história oral tornou-se um importante

\footnotetext{
${ }^{30}$ MEIHY, José Carlos Sebe Bom (org.). (Re) Introduzindo História Oral no Brasil. São Paulo: Xamã, 1996.

${ }^{31}$ FERREIRA, Marieta de Moraes, AMADO, Janaína. Usos e Abusos da História Oral. 8ed. Rio de Janeiro: Editora FGV, 2006.

${ }^{32}$ MEIHY, 1996, op.cit. p.08.
} 
denominador comum para todos que se aventuravam na seara que envolve entrevistas, gravações, arquivamentos, diálogos multidisciplinares" 33 . Entretanto, ao longo dos anos, a ampliação do uso de entrevistas em meios acadêmicos e não acadêmicos como recurso para o registro de histórias locais, grupos minoritários ou socialmente invisíveis, e como instrumento para a compreensão de fenômenos do tempo presente, somada à criação de espaços institucionais como associações e núcleos de pesquisa, permitiram a ampliação dos debates teóricos de forma que fossem estipulados procedimentos e usos específicos relacionados à prática da história oral. Diante do exposto, tornam-se necessários alguns apontamentos sobre o tema, sobretudo no Brasil, de forma a esclarecer a linha teórica que norteou a realização deste trabalho, ou seja, a desenvolvida no Núcleo de Estudos em História Oral, criado na Universidade de São Paulo em 1991 por José Carlos Sebe Bom Meihy.

\subsection{Procedimentos em História Oral}

A história oral se constitui como um conjunto de procedimentos que viabilizam a produção de narrativas por meios eletrônicos e que podem se destinar a diversas funções, de acordo com seus diferentes usos, objetivos e propostas teóricas. De acordo com Meihy e Holanda ${ }^{34}$, a realização do trabalho de pesquisa em História Oral implica o estabelecimento de seis momentos principais: Elaboração do projeto; gravação; estabelecimento do documento escrito e sua seriação; sua eventual análise; arquivamento e devolução social.

A elaboração do projeto constitui condição essencial para que se realize a história oral, visto que determina a forma como se darão os demais procedimentos. Assim, é importante que a proposta elaborada responda de forma pertinente a três questões fundamentais: De quem? Como? Por quê?

\section{De quem?}

As justificativas e objetivos elaborados pelo projeto de pesquisa apontam quais serão os possíveis entrevistados, ou seja, a comunidade de destino, o grupo convidado a

\footnotetext{
${ }^{33}$ Idem, p. 07.

${ }^{34}$ MEIHY, José Carlos Sebe Bom, HOLANDA, Fabíola. História Oral como fazer, como pensar. São Paulo: Contexto, 2007. p.30.
} 
participar do trabalho de investigação. Portanto, sua empatia com os objetivos da pesquisa é fundamental para sua continuidade.

No estudo proposto por esta tese, a comunidade de destino é composta por beneficiários das unidades de conservação de uso sustentável da cidade de Cananeia, mais especificamente, os beneficiários da Reserva de Desenvolvimento Sustentável Itapanhapima e os beneficiários da Reserva Extrativista Taquari. A escolha dos colaboradores com os quais realizei entrevistas, de forma a registrar suas histórias de vida deu-se pelo fato de que uma das principais características das unidades de conservação de uso sustentável é o estabelecimento de um modelo de gestão compartilhada que insere os beneficiários como sujeitos políticos detentores do poder de contribuir com as decisões que serão aplicadas pelo órgão gestor, no caso, a Fundação Florestal do Estado de São Paulo $^{35}$. Diante disso, as duas unidades compartilham o Conselho Gestor Deliberativo e seus beneficiários vivenciaram juntos o complexo processo de construção política desse espaço deliberativo. Geograficamente e culturalmente próximas, ambas foram inseridas no Mosaico de Unidades de Conservação do Jacupiranga a partir de um processo técnico realizado pelo Grupo de Trabalho (GT-PEJ), incumbido de elaborar a proposta de lei que seria encaminhada para a Assembleia Legislativa do Estado de São Paulo (ALESP). Ainda que visando assegurar os direitos de permanência e uso do território pelas populações em questão, foi possível constatar, por meio das narrativas que o caminho e os motivos pelas quais essas duas áreas foram inseridas nessa categoria socioambiental apresentam especificidades que se refletem nos atuais conflitos entre a legislação, aplicada na forma de gestão, e as críticas ao modelo apresentadas pelas populações locais ${ }^{36}$.

Em decorrência desses apontamentos iniciais, optamos por iniciar as entrevistas com pessoas que já participavam das reuniões do Conselho Gestor Deliberativo das unidades de conservação. Observando as atas documentadas e disponíveis na Fundação Florestal, percebemos uma grande variação de participantes desde as primeiras reuniões, ocorridas em 2010, até o momento presente. Segundo informações obtidas junto ao gestor Osmar Pontes, que permaneceu no cargo até o início de 2016, os beneficiários se demonstram descrentes quanto à efetividade das reuniões em relação à resolução dos seus

\footnotetext{
${ }^{35}$ Disponível em http://fflorestal.sp.gov.br/institucional/missao/ Acesso em março/2016.

${ }^{36} \mathrm{O}$ processo de criação do Mosaico de Unidades de Conservação será abordado com detalhes na terceira parte que compõe essa tese. Sobre o tema ver: BIM, Ocimar José Batista. Mosaico do Jacupiranga - Vale do Ribeira. Conservação, conflitos e soluções socioambientais. Dissertação (mestrado). São Paulo: Faculdade de Filosofia, Letras e Ciências Humanas da Universidade de São Paulo, 2012.
} 
problemas ligados à regulação do território, além de alegarem dificuldade em comparecer à Fundação Florestal, localizada na cidade de Cananeia, em decorrência de condições climáticas ou imposições de trabalho. Como estratégia de mobilização, o gestor tentou realizar reuniões alternando as áreas em que ocorriam. Como resultado, ampliava-se a participação dos moradores da região onde elas ocorriam e diminuía vertiginosamente a participação dos moradores de outras áreas. Essa irregular e parca participação mostrouse como um dos grandes desafios para a construção da gestão participativa e mais uma das dificuldades de aproximação com os possíveis colaboradores para a pesquisa. Essa primeira fase do trabalho de campo, permitiu-me compreender a diversidade de situações que envolvem as populações afetadas pelas unidades de conservação, posto que muitas realidades foram agregadas à categoria de beneficiários. $\mathrm{O}$ uso do termo beneficiário remete-se portanto apenas a uma questão legislativa que não traduz a complexidade cultural e política dos territórios. Em meio a essa diversidade, estabelecemos a identificação de três situações em relação ao uso da área, as quais deram origem a subdivisões da comunidade de destino que orientaram a escolha dos colaboradores:

- Beneficiários que moram e trabalham apenas na área rural, vindo à cidade pontualmente para vender ou comprar mercadorias, ir ao médico, bancos, etc.;

- Beneficiários que trabalham com pesca ou extrativismo na área de conservação onde possuem uma casa, ou uma estrutura mais simples para abrigo chamado de "rancho" (moradia de pesca), mas que também possuem casa na área urbana, onde a família mora e para onde voltam diariamente ou depois de alguns dias;

- Beneficiários que moram na área de conservação ou no seu entorno e possuem casa na cidade apenas como um local de apoio quando necessitam da estrutura não oferecida pela área rural, ou para a venda de suas mercadorias.

É importante ressaltar em relação ao projeto de pesquisa que ele se constitui como um planejamento inicial. Dessa forma, ao longo do seu desenvolvimento, ocorreram fatos que, embora não previstos, foram determinantes para o processo de elaboração do corpus documental. Dentre eles, destacamos que mesmo dentre as pessoas que mais ativamente participavam do Conselho Gestor (ou que foram indicadas por elas como possíveis colaboradores), ao longo do processo muitas desistiram de realizar as entrevistas pelos mais variados motivos. Além disso, das narrativas dos colaboradores emergiu a figura do 
Padre João 30 que se demonstrou importante para a compreensão do contexto em que se deu o processo de resistência dos moradores em seus territórios mas que, infelizmente, já havia falecido. Diante da recorrência do tema nas histórias de vida, optamos por incluir sua trajetória de luta junto às populações rurais de Cananeia, o que foi possível por meio de uma entrevista temática realizada com a senhora Maria Aparecida Rangel, muito conhecida na cidade por sua militância junto ao padre João durante todo o período em que ele atuou em Cananeia.

\section{Como?}

Parte da elaboração do projeto, é também fundamental definir o "lugar $d a$ história oral como forma de conhecimento" "37. A necessidade de tal definição decorre do aprofundamento do debate teórico promovido pela ampliação do seu uso. Dessa forma, tais debates remetem ao estatuto da história oral. Segundo Meihy e Holanda:

Uma primeira decorrência da busca de autonomia ou da melhor definição de história oral diz respeito ao seu estatuto. Convém logo questionar qual o lugar da história oral no conjunto do conhecimento do mundo moderno, dentro e fora do meio universitário. Usualmente, para qualificar a história oral são apontadas cinco possibilidades. A saber, a história oral como: 1- ferramenta 2- técnica 3- metodologia 4-forma de saber 5- disciplina. ${ }^{38}$

As diferentes propostas procedimentais podem oferecer resultados satisfatórios desde que fundamentadas de acordo com os objetivos que visam alcançar. Ainda segundo Meihy e Holanda, o cuidado com a definição teórica decorre do alcance atingido pela história oral dentro e fora das universidades e em diferentes contextos sociais, gerando uma disputa pelo direito de praticar a história oral ${ }^{39}$. Nesse sentido, os diferentes lugares conferidos a ela não devem ser desmerecidos, mas responder aos projetos que a justificam, reiterando seu caráter democrático. Dentre as muitas possibilidades teóricas se faz necessário, como ponto de partida, apresentar sob qual perspectiva esse trabalho se desenvolveu. Antes, porém, consideramos importante destacar algumas questões relevantes à visão que defende a história oral como metodologia.

\footnotetext{
${ }^{37}$ MEIHY, José Carlos Sebe Bom, RIBEIRO, Suzana L. Salgado. Guia Prático de História Oral: para empresas, universidades, famílias. São Paulo: Contexto, 2011, p.36.

${ }^{38}$ Para um aprofundamento sobre as especificidades das diferentes qualificações da história oral ver: MEIHY, José Carlos Sebe Bom, HOLANDA Fabíola. História Oral - como fazer, como pensar. São Paulo: Contexto, 2007. p.65.

${ }^{39}$ Idem, p.66
} 
Para Ferreira e Amado, a história oral como metodologia estabelece e ordena procedimentos de trabalho, sendo o campo em que a prática procedimental encontra seu suporte teórico. Dessa forma, “a história oral é capaz de apenas suscitar, jamais de solucionar questões, formula as perguntas, porém não pode oferecer respostas ${ }^{40}$ ". Segundo as mesmas autoras, essas respostas devem ser buscadas na teoria da história, atrelando a história oral a essa área do conhecimento disciplinar. Ainda que admita contribuições provenientes de outras disciplinas, essas devem prestar-se a oferecer suporte teórico a fim de resolver os dilemas propostos pelo trabalho historiográfico.

Aprofundando a discussão em torno da história oral como metodologia, Lozano faz apontamentos acerca do caminho de construção da história oral. Parte da ideia de que muitos estudos sobre a oralidade foram ensaiados pela antropologia, relacionando-a à tradição oral, sobretudo em sociedades rurais. Entretanto, segundo o mesmo autor, a questão da oralidade transcendeu o campo da antropologia transformando-se em "objeto de estudo de outras disciplinas, como é o caso atualmente, da corrente historiográfica denominada história oral". Ainda segundo Lozano, a história oral como método compartilha com a historiografia tradicional diversas fases e etapas do exame histórico: primeiramente, a construção de uma problemática inserida em um projeto de pesquisa. Em um segundo momento, desenvolve os procedimentos pertinentes "à constituição das fontes orais que se propôs a produzir" e por fim, "passa à análise e à interpretação das evidências e ao exame detalhado das fontes recompiladas ou acessíveis" ${ }^{41}$. No entanto, assinala pensar a história oral como um espaço de contato e influência interdisciplinar cujo principal papel é oferecer interpretações qualitativas de processos históricos-sociais. Trata-se de uma abertura temática e metodológica que "procura destacar e centrar sua análise na visão e versão que dimanam do interior e do mais profundo da experiência dos atores sociais" ${ }^{42}$. Dessa forma, a análise de fontes orais propicia uma imersão nas experiências do outro. Como percepção da realidade vivida, as narrativas se remetem à interdisciplinaridade na medida em que sua análise e contextualização exigem conhecimentos de temas que muitas vezes pertencem ao campo teórico de outras disciplinas. Aprofundando a discussão sobre interdisciplinaridade em trabalho publicado

\footnotetext{
${ }^{40}$ FERREIRA, Marieta de Moraes, AMADO, Janaína. Usos e Abusos da História Oral. 8ed. Rio de Janeiro: Editora FGV, 2006. p.16/17.

${ }^{41}$ LOZANO, Jorge Eduardo Aceves. Prática e estilos de pesquisa na história oral contemporânea. In: FERREIRA, Marieta de Moraes, AMADO, Janaína. Usos e Abusos da História Oral. 8ed. Rio de Janeiro: Editora FGV, 2006. p.21.

${ }^{42}$ Idem, p. 16.
} 
posteriormente, o autor assume a ideia de que a história oral pode ser concebida como uma disciplina. Segundo Lozano:

A la historia oral se le puede concebir como una "corrente disciplinar" cuyo campo de influencia y acción no se restringe a un solo país o a un continente, ya que en la actualidad es una práctica de investigación internacional que há construído sus proprias redes y campos de interrelación. Sin embargo, no se identifica con una disciplina en concreto; es decir, la historia, ya que participan una diversidade de estilos y procedencias profissionales; la interdisciplinar es uno de sus elementos característicos. ${ }^{43}$

Acreditamos, portanto, que a história oral pode superar sua condição de metodologia historiográfica e, por meio de análises pautadas pela interdisciplinaridade, direcionar seus esforços e contribuir com processos de transformação social e de formulação de políticas públicas, aproximando-se da visão daqueles que reivindicam seu caráter disciplinar. Segundo Meihy e Holanda:

O tema da transformação social, nessa alternativa, torna-se vital, supera os limites impostos pelos demais procedimentos, que se restringem em seus espaços conceituais. Pensar a história oral como mecanismo de mudanças sociais é mais do que vê-la como mero recurso formal de conhecimento. Ainda que muitos desprezem essa dimensão, aos que lutam pela história oral como disciplina, ela carrega promoção das transformações em políticas públicas. ${ }^{44}$

\section{Por quê?}

Essa terceira questão se entrelaça à opção metodológica que situa a história oral como disciplina. Ainda que esta definição constitua uma tendência radical, é coerente com a problemática desenvolvida por esta pesquisa. Isso porque nosso objetivo analítico é permitir que a perspectiva dos nossos colaboradores, apresentada pelas narrativas, possam trazer novos elementos à discussão pertinente aos conflitos decorrentes da implementação da legislação socioambiental em territórios tradicionalmente ocupados. Dessa forma, reiteramos o caráter social da história oral ao apresentar subsídios críticos à formulação de propostas de políticas públicas voltadas para essa população. Acreditamos também tratar-se de um caminho teórico coerente com a proposta do programa interdisciplinar no qual esta pesquisa se desenvolveu, intitulado "Humanidades,

\footnotetext{
${ }^{43}$ LOZANO, Jorge Eduardo Aceve. La Historia Oral contemporânea uma mirada plural. In: Historia Oral: ensayos y aportes de investigación. México: Ciesas, 2000. p.10.

${ }^{44}$ MEIHY, José Carlos Sebe Bom, HOLANDA, Fabíola. História Oral - como fazer, como pensar. São Paulo: Contexto, 2007. p 76.
} 
Direitos e Outras Legitimidades", e promovido pelo Diversitas - Núcleo de Estudos das Diversidades, Intolerâncias e Conflitos, criado a partir da iniciativa de:

“(..) docentes pesquisadores de diversas áreas do saber - sociologia, comunicações, história, antropologia, psicologia, geografia, direito, meio ambiente - que se ocupam da investigação de questões pertinentes à diversidade cultural. $\mathrm{O}$ esforço conjunto decorre de insatisfações de limitações e resultados sempre parciais das abordagens disciplinares no entendimento de fenômenos como a violência, as desigualdades, as tradições e ausência de direitos de parcelas significativas da população, assim como da sociabilidade, da preservação ambiental e do patrimônio em espaços urbanos e rurais, hoje fortemente ameaçados". ${ }^{45}$

Compreendemos, portanto, que o trabalho interdisciplinar, assim como a história oral, não se resume a uma relação entre a história e o uso utilitário das demais disciplinas de forma a encontrar soluções teóricas. Segundo nossa perspectiva, os procedimentos apresentados pela história oral como disciplina permitem um diálogo entre campos disciplinares como a história, a geografia, antropologia, ecologia e sociologia que, em conjunto com os saberes locais apresentados nas narrativas, propiciaram a realização de projetos voltados para ações afirmativas. Segundo Meihy e Holanda:

O que se propõe com a modificação do estatuto da história oral é que ela se torne um lócus permanente, equilibrado e bem constituído para a formulação de propostas que se assentam no presente como resposta de um passado que não levou em conta a inclusão social de grupos e pour cause os fundamentos da democracia. ${ }^{46}$

Dessa forma, ainda que tal proposta pareça nova e audaciosa, concordamos com Meihy e Holanda ao afirmar que se trata de uma perspectiva teórica que se remete aos fundamentos da história oral, que desde seu início teve como principal preocupação e fecundidade "o compromisso social marcado pela voz dos excluídos, revelação de aspectos desconhecidos, ocultos e desviados, não expresso nos documentos oficiais e escritos, e sobretudo, a denúncia do sofrimento extremo de grupos maltratados por situações variadas. "

Esclarecida a proposta teórica do projeto de pesquisa, passemos às demais etapas e procedimentos em história oral que nortearam a realização desta pesquisa.

\footnotetext{
${ }^{45}$ http://diversitas.fflch.usp.br/pos/tema Acesso em outubro/2016.

${ }^{46}$ MEIHY, José Carlos Sebe Bom, HOLANDA, Fabíola. História Oral - como fazer como pensar. P.78/79.
} 


\section{As entrevistas}

A construção de fontes a partir de registros orais sempre apresenta para o pesquisador o desafio do encontro com as vivências e experiências do outro por meio do trabalho de campo. Mais do que um desafio de alteridade, tal processo de compartilhamento de experiências por meio das narrativas produzidas exige a realização de um conjunto de procedimentos que incluem, além da elaboração de um projeto, o planejamento de sua execução. Consideramos que parte desse planejamento remete à criação de estratégias que viabilizem não apenas o encontro com os sujeitos históricos, mas a realização de um trabalho que apenas pode ser feito em colaboração, ou seja, a partir do consentimento entre entrevistador e entrevistado. Assim, consideramos fundamental destacar a importância do conceito de colaboração desenvolvido por José Carlos Sebe Bom Meihy ${ }^{47}$. A ideia de colaboração parte do fato de que a relação de produção documental é necessariamente dialógica, ou seja, uma via dupla em que entrevistador e entrevistado colaboram mutuamente para a construção do documento. Trata-se de uma tentativa de realizar a produção compartilhada de conhecimento a partir de experiências diferentes envolvidas no mesmo processo: o pesquisador com sua experiência acadêmica e o colaborador que possui o privilégio do vivido. Ambos passarão pelo processo de elaboração da narrativa histórica a partir da memória do entrevistado, permitindo uma experiência única e conjunta de revisitar o passado a partir do contexto presente. E por isso, ainda que o eixo das entrevistas se situe em momentos já vividos, portanto passados, a experiência de lembrar se dá no tempo presente. Desse modo, o contexto e o acúmulo de experiências moldam a reelaboração constante do fato vivido. Segundo Ecléa Bosi:

Na maior parte das vezes, lembrar não é reviver, mas refazer, reconstruir, repensar, com imagens e ideias de hoje, as experiências do passado. A memória não é sonho, é trabalho. Se assim é, deve-se duvidar da sobrevivência do passado, "tal como foi", e que se daria no inconsciente de cada sujeito. A lembrança é uma imagem construída pelos materiais que estão, agora, à nossa disposição, no conjunto de representações que povoam nossa consciência atual. ${ }^{48}$

\footnotetext{
${ }^{47}$ MEIHY, José Carlos Sebe Bom, HOLANDA, Fabíola. História Oral - como fazer, como pensar. p.161.

${ }^{48}$ BOSI, Ecléa. Memória e Sociedade: lembranças de velhos. p.55.
} 
Considerado pela autora como um trabalho, a memória, enquanto ato de lembrar, é influenciada pelo fato de que nos transformamos o tempo todo graças ao que experimentamos, e a nossa consciência de mundo, valores e percepções se alteram sob esse princípio. As representações que criamos do passado partem, portanto, da forma como reelaboramos a compreensão do que foi vivido. Por isso, a experiência da entrevista é única e insubstituível: a cada elaboração, criam-se novos caminhos não lineares e novas reelaborações sobre a mesma questão. Ou ainda, enfatiza-se um determinado aspecto que, num outro momento, pode não ser tão significativo.

Com o intuito de me aproximar dos beneficiários e tornar possível o registro do trabalho de memória elaborado pelos colaboradores, apresentei-me ao senhor Osmar Pontes, gestor das unidades de conservação e funcionário do Instituto Florestal. Além de obter uma autorização formal do Conselho Técnico Científico (COTEC) da Fundação Florestal, o projeto foi apresentado e aprovado durante uma reunião do Conselho Gestor Deliberativo. Neste espaço de encontro, foi possível explicar como seria o processo de pesquisa e aproximar-me dos futuros colaboradores para a realização das entrevistas e construção da base documental do trabalho por meio das histórias de vida. O trabalho de campo foi realizado principalmente entre 2013-2016, período em que frequentei grande parte das reuniões institucionais, nas quais realizava os contatos para a gravação das entrevistas. As reuniões de gestão tornaram-se minha principal forma de acesso aos beneficiários, dadas as dificuldades de localizá-los em outros lugares: grande mobilidade e alternância entre o meio rural e urbano; a não existência de um cadastro completo dos beneficiários por parte da Fundação Florestal; condições de acesso às áreas onde estão as unidades de conservação. No caso da RESEX Taquari, o acesso se dá pela estrada Itapitangui-Ariri. Essa estrada não asfaltada atravessa toda a área continental de Cananeia e tem seu ponto final no bairro Ariri, ponto extremo que faz fronteira com o Estado do Paraná. São aproximadamente $60 \mathrm{~km}$ de estrada úmida e cortada por diversos rios da região, que frequentemente elevam seu nível nas cheias e impedem a passagem. Atualmente, a manutenção da estrada tem sido mais eficiente, mas, mesmo assim, não é recomendável trafegar por ela em dias chuvosos ${ }^{49}$.

\footnotetext{
${ }^{49} \mathrm{O}$ alto índice pluviométrico de Cananeia é uma das características marcantes da cidade. Dessa forma, era comum esperar por dias até que a estrada se mostrasse segura e o trabalho de campo fosse possível.
} 
No tocante à RDS Itapanhapima, o acesso por terra se dava por uma trilha ou "caminho de tradição" "50, que ligava essa estrada Itapitangui - Ariri às áreas dos moradores, e que hoje não existe mais. O único acesso é, portanto, via barco pelos canais do complexo estuarino lagunar Cananeia - Iguape. Os sítios dos beneficiários são isolados e identificar seus locais de entrada requer conhecimento sobre o território ${ }^{51}$. Tais fatores dificultaram o trabalho, mas também foram importantes para compreender os problemas do cotidiano dos beneficiários. Outro aspecto importante é que no caso das entrevistas realizadas nas áreas rurais, nos sítios dos beneficiários, o trabalho apresentou peculiaridades procedimentais que evidenciam características das comunidades de destino às quais nos referimos. Normalmente as entrevistas em história oral são realizadas de forma individual, apresentando o sujeito, o narrador, também como indivíduo. Ocorre que essa noção de privacidade e individualismo não constitui um aspecto relevante ao modo de vida dos beneficiários colaboradores. Não era possível - e nem interessante, dado que essa característica local apresenta questões importantes à reflexão - forçar um momento de total individualidade e privacidade entre entrevistador e entrevistado. Diante desse contexto cultural, muitas entrevistas foram realizadas com a participação do casal ou mesmo de outros membros da família presentes no momento. Como já afirmado, em história oral o conjunto de procedimentos elaborados no projeto inicial prevê a possibilidade de adaptar-se ao que é oferecido pelo contexto da pesquisa. Também atenta ao fato de que todos esses elementos se apresentam subjetivamente nas narrativas e são significativos para análise do conjunto de histórias de vida, que serão transformadas em fontes documentais. Dessa forma, busquei respeitar a forma, o lugar e as condições que a família, ou os colaboradores, escolheram para realizar os registros. Diante dessa postura, cada entrevista tornou-se um ritual singular em relação aos demais, no qual mais ou menos esforço, ou mesmo insistência, foram necessários. Grande parte das entrevistas levaram meses de negociação, sendo que algumas não aconteceram por motivos muito variados, de ordem pessoal, climáticos, ligados ao trabalho dos colaboradores, ou decorrente da desconfiança por parte de alguns beneficiários que associam o trabalho de pesquisa à ação do Estado e por isso temem falar. Outros se mostraram dispostos e

\footnotetext{
50 Segundo Maria Aparecida Rangel, colaboradora desse trabalho, caminho de tradição é uma via de circulação coletiva mantida pelas populações rurais. O fato do caminho de tradição que liga a estrada do Ariri e os bairros do Retiro e Itapanhapima estar fechado decorre da vertiginosa diminuição da população local e o abandono do uso e manutenção coletiva do caminho.

${ }^{51}$ Em decorrência do isolamento dos sítios, contratar um barqueiro também foi um processo difícil visto que ele deveria conhecer os locais específicos e que não constituem pontos turísticos. A solução encontrada foi a contratação de barcos dos beneficiários, o que, no entanto, dependia da disponibilidade deles.
} 
prontamente se dispuseram a falar sobre os problemas que afetavam as áreas, enfatizando o fato de que sempre foram pouco ou nada ouvidos no processo de criação e gestão das unidades de conservação. Dessa forma, o processo de formulação e registro da experiência foi um momento de revisitar as histórias de família, o modo de vida em comunidade, as dificuldades de permanência no território e a organização da resistência pelos moradores, a criação dos filhos, os primeiros acontecimentos ligados à implementação das unidades de conservação e o quanto esse processo alterou a antiga forma de vida, principalmente no tocante à agricultura. Além disso, as narrativas apresentam também reflexões sobre o atual momento de construção da gestão e sobre os principais limites impostos pela proposta de criação de um território institucionalmente tutelado, mas que seja capaz de propiciar um desenvolvimento que proteja o meio ambiente ao mesmo tempo em que permita uma vida digna para os moradores reconhecidos como detentores de direitos territoriais e culturais. São histórias em que passado e presente dialogam, permitindo ao leitor aproximar-se da trajetória de luta e resistência daqueles que interagiram por gerações com o patrimônio ambiental e cultural da região.

No tocante aos aspectos técnicos e procedimentais que envolvem o processo de registro e passagem da fonte oral para a fonte escrita, é importante ressaltar que o documento escrito final não se constitui na íntegra de entrevista oral. Para além da entrevista, o processo em questão envolve principalmente três momentos: a transcrição, a textualização e a transcriação. A primeira refere-se ao trabalho bruto, a íntegra das narrativas transformadas em códigos escritos. A textualização retira os estímulos, ou seja, as perguntas, realizadas pelo pesquisador, além de alguns vícios de linguagens e repetições não relevantes à compreensão do narrado. Já a transcriação constitui o procedimento mais ativo do pesquisador, na medida em que permite a realocação e adequação de formas de concordância gramatical que facilitem a compreensão. A linguagem oral é diferente da escrita, pois possui entonações, sentimentos, risos, suspiros e tantas outras expressões de forma que não seria possível reproduzi-la literalmente. Ao assumir sua forma escrita, a adequação é feita de maneira a aproximar os universos, buscando uma maior compreensão. Seria como se, poeticamente, passássemos a fazer parte da história de vida narrada. O pesquisador passa a ser também o autor que tem a tarefa de transformar a fonte em algo organizado, de forma que se mantenha o sentido e seja agradável ao leitor. A validação da entrevista se dá no momento em que são apresentadas as versões aos colaboradores e esses se reconhecem na fonte escrita. Nesse 
momento do trabalho, feito com algumas mãos, o colaborador revisita sua própria história e autoriza - ou não - sua utilização como fonte documental. Isso porque as entrevistas serão apresentadas no trabalho de forma integral, sem que sejam feitos apenas recortes que justifiquem uma ou outra afirmação pressuposta. A ideia é que o documento seja disponibilizado de forma a possibilitar o surgimento de novas análises e compreensões, para além das que este trabalho pretende apresentar.

\section{Análise}

Os grupos que compõem esse estudo possuem em comum a experiência de pertencer a um processo de transformação de seus territórios em áreas de conservação e do reconhecimento que lhes concedeu o caráter político de populações tradicionais. São aspectos que estão presentes na forma como os colaboradores atuam e elaboram seu atual momento de vida, tendo em vista que tal fato faz parte do cotidiano de todos. Dessa forma, suas histórias de vida, ainda que individuais, possuem aspectos que dizem respeito à coletividade. São esses fatores que nos permitem, vislumbrando o conjunto de narrativas, perceber evidências que remetem à existência de um vivido coletivo. A partir de narrativas individuais podemos, portanto, perceber a existência de evidências capazes de compor uma memória coletiva ${ }^{52}$. A importância dessa memória construída a partir da atividade mnemônica, e identificada por meio do trabalho de análise, deve-se à possibilidade de nos aproximarmos da maneira como o outro percebe a experiência coletiva. O trabalho de análise consiste, portanto em:

- Identificar e analisar os conflitos e as críticas ao modelo de gestão implementados nas unidades de conservação sustentáveis, sob a perspectiva dos beneficiários;

- A partir dessas críticas, propor encaminhamentos elaborados a partir das demandas apontadas pelos beneficiários, respaldados pela bibliografia interdisciplinar pertinente ao tema.

\footnotetext{
${ }^{52}$ HALBCHAWS, Maurice. A memória coletiva. p.72.
} 


\section{Arquivo e devolução}

A publicação e a devolução do trabalho envolvem questões ligadas à ética própria aos procedimentos em História Oral. Compartilhar a produção final com a sociedade por meio da divulgação é um dos aspectos pertinentes a essa ética, mas devolver o trabalho à própria comunidade é de extrema importância. No tocante a esta tese, realizaremos como propósito devolutivo:

- A entrega de cópias da tese para os colaboradores;

- A entrega de um conjunto de fotografias com as imagens que não foram incluídas no trabalho final;

- A entrega de um vídeo criado a partir de trechos editados de conversas e entrevistas realizadas com os colaboradores;

- A entrega de cópia da tese para a Fundação Florestal com o intuito de compor o acervo de pesquisa da instituição e de colaborar com o trabalho de gestão desenvolvido nas unidades de conservação. 


\section{Cananeia: Território e resistência.}

Neste capítulo apresento a história do Padre João 30, referência no processo de organização popular contra a expulsão territorial para as pessoas que colaboraram com esta pesquisa. Quando estimulados a falar sobre os problemas fundiários pelos quais passaram, a figura do padre João é lembrada como alguém que aliava conhecimento jurídico ao trabalho comunitário, orientando os moradores sobre direitos territoriais ao mesmo tempo em que pessoalmente enfrentava grileiros e o poder público da cidade. $\mathrm{O}$ Padre João 30, como ficou popularmente conhecido entre os moradores da cidade, nasceu na Holanda e seu nome era na verdade Jan Van Der Heijden. O nome João 30 era um apelido assumido pelo padre e que simplificava seu nome de forma a facilitar a comunicação com a população local. Chegou em Cananeia na década de 1970 e aí permaneceu até bem próximo de sua morte em 2008. Durante praticamente toda sua permanência no local, contou com a colaboração de Maria Aparecida Rangel, moradora do bairro Carijo na cidade de Cananeia, leiga e atuante da comunidade católica da cidade naquele período. Foi ela quem, após a morte do padre João, tentou manter a casa que ele havia construído, e onde havia morado na cidade, como uma espécie de memorial em que guardava toda a vasta documentação produzida pelo padre. Nesse extenso arquivo, ele relata com detalhes grande parte das histórias dos conflitos locais entre populações tradicionais, grileiros e poder público nas áreas que hoje representam parte das Unidades de Conservação presentes no município. São relatórios enviados ao primeiro bispo da Diocese de Registro Dom José Aparecido Dias, militante do Conselho Indigenista Missionário (CIMI) e da Pastoral da Terra (CPT), e a organizações não-governamentais, como a S.O.S Mata Atlântica e a Trocáire ${ }^{53}$, que colaboravam com seu trabalho. Outros documentos são textos reflexivos que tinham como objetivo registrar denúncias e sua visão sobre política, meio ambiente, direito de povos tradicionais e uma série de outros temas relativos aos diversos conflitos presentes na cidade de Cananeia, sobretudo na área rural. Além disso, produziu uma grande quantidade de imagens sobre os muitos momentos de trabalhos realizados junto às comunidades, aliando conscientização política

\footnotetext{
${ }^{53}$ Trocaire é uma palavra irlandesa que quer dizer misericórdia e foi o nome que a organização Internacional católica Caritas assumiu na Irlanda. http://www.caritas.org/es/donde-estamos/europa/irlanda/. Trata-se de uma agência fundada em 1973 com o objetivo de fomentar o desenvolvimento da Igreja Católica no ultramar. "La organización recibió un doble mandato: aliviar la pobreza y la injusticia en el extranjero, y educar a la gente en el país (,) sobre las causas estructurales de la pobreza”.
} 
aos ritos religiosos e à doutrina cristã. Infelizmente, após a morte do Padre João, a casa foi retirada das mãos de Maria Aparecida Rangel, segundo ela mesma, por um processo de recuperação de posse efetuado pela própria Igreja local. Toda essa vasta documentação foi transferida para sua própria (e pequena) casa e ela permanece como guardiã da memória do padre apesar das parcas condições de espaço físico e recursos financeiros que possui. Em decorrência, sobretudo, dessa exiguidade de espaço e dificuldade de organização, foi pouco o tempo que dispus ao acesso a essa documentação tão rica e quase inexplorada.

\section{Maria Aparecida Rangel, auxiliar do padre João 30 e moradora do bairro Carijo em Cananeia.}

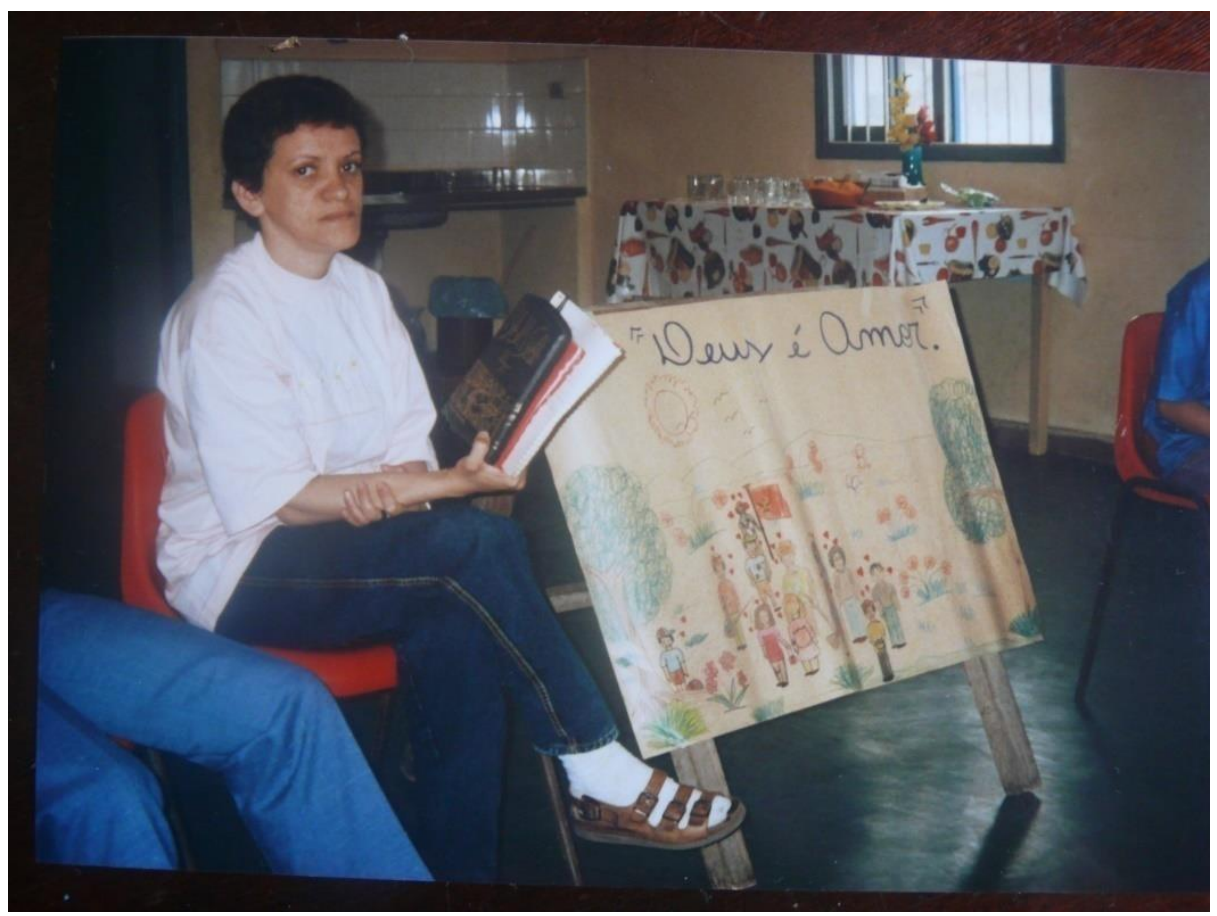

Foto: Acervo pessoal de Maria Aparecida Rangel

Conheci Maria Aparecida Rangel nas histórias de vida dos primeiros colaboradores dessa pesquisa, em especial Dirce e Armando Davi. Lembrada com muito carinho, foi por eles destacada como alguém que, auxiliando o trabalho do Padre João 30, fez parte da luta das populações locais organizadas para resistir às mais diversas formas de violência decorrentes do avanço da grilagem e dos conflitos entre o modo de vida local 
e a legislação ambiental. Moradora da cidade, ainda hoje é extremamente atuante na comunidade local, em especial na Colônia de Pescadores Z9 Apolinário Araújo que representa os pescadores tradicionais de Cananeia. Entrevista realizada em novembro de 2014.

\section{A menina dos olhos do padre João sempre foi a população caiçara, o meio ambiente, a pesca, a questão da terra e de toda sua problemática (...)}

Quando o Padre João chegou a Cananeia eu já era do grupo de jovens e tinha 14, 15 anos. Nessa época, nós estávamos na oitava série ou coisa assim. A gente estava bem entrosada com catecismo e outras atividades da Igreja. Quando veio essa história da saída do pessoal das áreas que viraram parques, em setenta e dois, o Padre João já veio para cá. No início para fazer visita à Igreja Católica. Tinha um padre que estava morando aqui e que ficava na casa paroquial para fazer missas, batismo e casamento, $e$ depois ia embora, mas foi por pouco tempo. Quando o Padre João viu isso, ele veio para cá de vez. Ele falou assim: vamos fazer uma pesquisa em Cananeia. Não tem porta nenhuma que a gente não vá bater. Ah, mas aquele é crente. Então pode bater. O Padre João era assim: chegava em todo lugar e batia nas portas com o grupo de jovens que ele tinha aqui. E então ele fez uma pesquisa começando pela Ariri ${ }^{54}$. Casa por casa. Qual a religião que você tem, com todo o respeito? Eu sou um Padre e gostaria de vir para cá. Então ele perguntava para os que se diziam católicos, se eles tinham interesse em ter alguém, ter a visita do padre. Ele fez essa pesquisa com todo mundo. Foi indo em cada lugar. E já foi vendo com quem ele poderia ter contato numa próxima vez, com qual família. Então, já tinham famílias que ficavam de fazer esse trabalho em cada lugar. Eles ficavam o tempo inteiro conectados para se falar. E assim foi feito uma pesquisa muito grande em Cananeia toda, em setenta e dois.

Descobriu-se então essa história da Ilha do Cardoso ${ }^{55}$. E então, o que vamos fazer? O pessoal só falava disso, e ele anotava tudo. E como ele anotava tudo, fazia uma ficha de cada um. Essas coisas de família, antepassados e tudo isso. Foi isso que fez com que o histórico dele salvasse os moradores quando o governo veio falar que podia tirar

\footnotetext{
${ }^{54}$ Bairro de Cananeia continental que faz fronteira com o Paraná.

55 O PEIC - Parque Estadual da Ilha do Cardoso - criado em 1962, constitui uma das primeiras unidades de conservação criadas na região e gerou um intenso conflito entre moradores locais e estado, em decorrência de um violento processo de expulsão dessas populações. http://www.ambiente.sp.gov.br/ilhado-cardoso/
} 
todo mundo de uma vez. Foi esse papel que, na verdade, se juntou com um documento de cada pessoa. Nessa época foi a primeira vez que aconteceu. Em setenta e três, mais alguns resolveram sair. E alguns resolveram ficar. Então o Padre João falou: não, então vou lutar com vocês. O Padre João foi programando com o advogado Antônio Teleginski ${ }^{56}$, que era advogado do estado de São Paulo. Ele também já morreu, logo depois do Padre João. O Padre João já morreu faz oito anos, e ele vai fazer de quatro para cinco anos. Só que ele trabalhou o tempo inteiro com o Padre João. Quando o governo mandava o advogado do estado para vir, o Padre João já conversava com o advogado e falava: não, não é assim, é assim, assim e assim. E mesmo ele sendo do estado, ele trabalhava contra o estado, entendeu? Ele era do estado, do meio ambiente, mas ele trabalhava como advogado do Padre João em defesa das populações. E então ele lutou o tempo inteiro. E tinham mais alguns advogados do estado de São Paulo, que eram famosos pelo seu conhecimento e que trabalharam só para a gente e que também eram amigos do Padre João de muito tempo e também vieram para ajudar o Padre João nessa história da Ilha do Cardoso. Eles foram fazendo muitas documentações e conseguiram barrar algumas coisas no começo. Mas quando chegou em oitenta e um, eles fizeram novamente uma investida de tirar o povo.

Em setenta e quatro, o Padre João já veio e já ficou. E eu, em oitenta, já estava trabalhando na contabilidade. Trabalhei até em oitenta e três. Era um escritório de contabilidade próximo da Igreja. Então, o Padre João passava e conversava comigo. Quando em oitenta e um veio essa investida, o Padre João falou: ah, essa luta agora tem que ser maior. Tem que fazer um mutirão muito grande e trazer toda a população da Ilha do Cardoso para Cananeia. A gente tem que fazer um documento para eles assinarem, uma declaração que eles são moradores do local, com todos os dados. Mas trazer todo mundo. Pai, filho, mãe... E era muita gente. Foi o maior mutirão. Foi a primeira vez que vi um grande mutirão da luta, da grande luta por aquilo que já era chão dos nossos antepassados, e a gente queria manter. Foi uma grande luta mesmo. E o Padre João falou: nós vamos fazer. Então convocou todos os barcos dos pescadores: vocês todos, eu pago todo o combustível, e vocês vão buscar e trazer as pessoas. E os de lá, vocês também

\footnotetext{
${ }^{56}$ Antônio Teleginski foi um advogado especialista em direito fundiário e conhecido por sua militância na área ambiental. Trabalhou junto à SUDELPA, Superintendência para o Desenvolvimento do Litoral Paulista, órgão criado pelo governo do estado que dentre suas atuações, foi responsável por promover iniciativas ligadas à regularização fundiária no Vale do Ribeira. http://www.bioclimatico.com.br/pdf/entrevistas/SOS_HV013 \%20AntonioTeleginski.pdf
} 
convocam, que aqui a gente paga toda a comida e tudo. Mas tem que trazer todo o pessoal, não dá para trazer um só. E no meu escritório tivemos que fazer um combinado para que eu pudesse participar desse momento. Eu acho lindo, e a minha família não sabe disso. Eu nunca contei coisas assim. E eu não fiz isso para mostrar que sou melhor que os outros. Tanto que a minha família não sabe até hoje. Mas, eu achei um grande momento. Eu tive grandes momentos com o Padre João, mas o mais importante foi esse. O Padre João foi e falou com o meu chefe; olha, eu quero que você deixe a Cida trabalhar comigo, porque o povo já conhece ela. Assim, eles que venham aqui, e que ela atenda só eles. Não é para ela fazer o serviço da contabilidade, é para ela fazer a declaração de cada um, tudo certinho. E aí já vão assinando e deixando com ela, que ela sabe como é que tem que fazer. Depois vamos juntar tudo isso no processo, e juntar as documentações. E barrar o governo. E durante semanas fui recebendo todo mundo. Todo mundo que vinha aqui. E nós fizemos isso. E o meu chefe, apesar de não ser católico, ele era um grande amigo. Ele fez com que eu pudesse fazer isso. Nós juntamos tudo isso no processo, cada um de nós foi organizando isso em grupo. As pessoas vinham para assinar a declaração. Lá na área deles não tinha nada para fazer isso, e tinha que bater um monte de coisa. Era uma declaração de posse de quem morava lá. Já tinha feito uma cópia dessa declaração com o Doutor Antônio, e todos tinham que preencher com os dados no documento. Então tinha que trazer documentação. E quem não sabia assinar colocava o dedão. Como cada um tinha que fazer, demorava muito tempo. E por isso a vinda deles para cá. Não tinha como a gente ir até lá fazer um por um, porque era muito longa a viagem. Então era mais fácil trazê-los do que a gente ir. A gente fez tudo isso, juntou no processo e ficou muito grande. A partir daí, conseguimos que uma parte do povo não fosse mais expulsa da Ilha do Cardoso, por toda a documentação. Ele juntou documento de 1850, documentos das terras da Igreja, e passou a garantir a vida de quem quis ficar e viver no local. A gente sabe que onde tem um morador no local, ele não é um intruso, ele está sendo fiscalizador também. Ele ama aquela água, ele ama o peixe. Ele não pesca só por pescar, ele ama a espécie. E essa espécie, por exemplo, é ela quem dá vida para o que cada pescador conhece. O pescador conhece para o que ela pode servir, não só para comer. Sabe que ela tem um porquê de existir nas próprias outras espécies.

E é bonito ouvir os pescadores contando isso. Então os moradores vieram da Ilha do Cardoso todo, do Cambriú, Pontal ${ }^{57}$... Eu tenho ficha ali, de todos. Umas trezentas

\footnotetext{
${ }^{57}$ Comunidade caiçara da Ilha do Cardoso.
} 
pessoas na época. Porque os que ficaram eram famílias grandes. Por exemplo, o senhor Ezequiel $^{58}$, ele teve doze filhos. Na época ele já morava no Maruja ${ }^{59}$. O processo todo é imenso. A gente tem o levantamento da época, do que eles conseguiam dizer. Porque o povo caiçara era muito simples, eles não gostavam muito de falar. Eram muito quietos. E ainda é muito quieto, é muito difícil para você tirar alguma coisa de caiçara. É uma pessoa com quem você não consegue fazer isso. Até porque, ele foi marcado duramente na vida. Foi aquela velha história desde o começo: você só serve para fazer esse serviço, e não como um cidadão. A partir dessa história de lutar para ficar no local foi um salve aqui na cidade. O Padre João falou: está vendo a importância de você ser um morador caiçara, de um lugar específico como Cananeia? Por isso que no dicionário do Aurélio caiçara é um morador típico da cidade de Cananeia do estado de São Paulo. Existem para a lavoura caiçara definições pejorativas, mas no Aurélio caiçara é um morador típico de Cananeia do estado de São Paulo. Ele trazia essas informações para o povo. $O$ Padre João começou a trazer essas coisas importantes da palavra indígena. Porque lá atrás, eles falavam que índio não valia nada. E então começamos a valorizar. O Padre João falou: vamos começar a trazer novas ideias de valores para nossa vida, não de negatividade. São valores. Isso aqui é valor. Esse pedacinho de papel é um valor muito importante. Não se joga fora.

Essas coisas todas começaram a nascer. E nasceram então as comunidades. Mas também nessa época de setenta e quatro, quando o Padre João chegou, começou a vir um "progresso" para Cananeia. Entre aspas, o progresso. Em setenta e quatro, começaram a vir para Cananeia todos os grandes projetos para um determinado lugar. Por exemplo, veio para Cananeia ao mesmo tempo, a construção do entreposto da Ceagesp ${ }^{60}$. Também naquela época construíram uma mega obra, nós falávamos. Era a Quarentenária ${ }^{61}$, a construção dela era um elefante branco. Eu conheço, eu vi lá. E se você vir, é uma coisa de primeiro mundo. Lá, eles têm lagoa de tratamento próprio, esgoto próprio. E, quando você fala em Quarentenária, é um local que é uma ilha, onde

\footnotetext{
${ }^{58}$ Senhor Ezequiel é uma liderança da Comunidade do Marujá na Ilha do Cardoso e muito conhecido em toda a cidade, sobretudo em relação à militância pelos direitos da comunidade frente ao Parque Estadual da Ilha do Cardoso. Faleceu recentemente, no início de 2017. http://www.museudapessoa.net/pt/conteudo/pessoa/ezequiel-de-oliveira-24375 ${ }^{59}$ Comunidade caiçara da Ilha do Cardoso.

${ }^{60}$ Companhia de Entrepostos e Armazéns Gerais do Estado de São Paulo ${ }^{61} \mathrm{Um}$ dos principais objetivos da Estação Quarentenária de Cananéia é: possibilitar a quarentena de animais em um ambiente oficialmente controlado, em complemento às medidas de defesa sanitária animal aplicáveis aos processos de importação, de exportação e do trânsito nacional; http://ww3.panaftosa.org.br/Comp/MAPA/5321322.pdf
} 
tudo que tem lá é muito bom. A água é muito boa, a qualidade do peixe, a biodiversidade, a fauna e a flora... tudo bom. E por que construiu a Quarentenária? Existiam duas no Brasil. Agora só tem essa aqui. A gente viu a construção todinha começar. ... A Quarentenária, eu falo da questão do meio ambiente. Eu falo: gente, como é que pode deixar uma quarentenária entrar em Cananeia? Um local limpo, um local que tem uma ilha... O nome quarentena é quando você está doente.

Então, se você está doente, às vezes você tem que ficar seis meses, um ano para melhorar. Quer dizer: só que esse doente atravessa a cidade inteira para chegar aqui no Carijo $^{62}$. Inclusive, ele passa na frente da escola onde estão as crianças, e passa pela minha rua aqui. Não tem outro lado por onde passar. Então todos esses doentes que passam pela quarentena, eles passam por aqui sempre. E eles deixam as fezes, a urina. Nenhum bicho é tapado para entrar da cidade para cá. Não tem um controle na entrada, aqui. O que eu falo é da parte da vigilância sanitária, não existe esse controle para estar podando certos tipos de entrada. Até hoje tenho isso como uma incógnita para mim.

Não pode entrar ninguém mais lá. Só entram esses grupos que fazem estudo. Entram os bichos. E quando o bicho está lá, não entra ninguém. E fica assim. E a área que eles têm, não é só uma construção, é uma construção de primeiro mundo. A construção de área e a mata que eles assumiram para a quarentenária é imensa. A ponto que, no ano passado, eles expulsaram pescadores que estão próximos. Desapropriaram as casas naquela região. E isso não podia. E não era por ser casa de moradia, era por derrubar aquela cobertura do pescador que ficava ali dormindo três, quatro dias, para ficar fazendo essa pesca. Quando a quarentenária entrou para derrubar essas casas, o Padre João pegou esse documento de mil oitocentos e tantos, e falou: não, tem os nossos antepassados, está escrito aqui e não vai tirar de jeito nenhum. Mas até então, só tinham essas casas dos pescadores. O dinheiro é uma coisa que machuca muito e acabou pegando essas áreas. E então tiveram que sair.

Nessa época construíram também o Colégio Iolanda, onde passei a estudar. Eu terminei os meus estudos lá, em setenta e seis. Então veio a Ceagesp, escola, quarentenária e tudo ao mesmo tempo.... Foi também feita a abertura da estrada do Ariri $^{63}$. Foi nessa época, tudo nessa época. Então por isso essa época foi chamada de

\footnotetext{
62 Bairro da área urbana de Cananeia.

${ }^{63}$ Bairro rural de Cananéia continental que fica no extremo do território e faz divisa com o Paraná.
} 
progresso de Cananeia. Ah! Tem também a construção do hotel Glória ${ }^{64}$. E que não foi acabado. Tudo com o dinheiro do governo. Então, para que fazer certas coisas em Cananeia? Para algumas coisas funcionaram, mas para outras, não. Porque o terminal do Ceagesp só acabou sendo usado para o industrial e não para o artesanal. E até hoje é só para o industrial. Não foi feito nada para o pescador artesanal. Então foi feito tudo para quem já tem dinheiro, e menos para quem não tem. A escola, sim. A escola foi uma grande coisa. A estrada do Ariri, ela foi aberta, mas nunca mais foi feito mais nada. $O$ hotel Glória virou só hotel para rico. Não tinha outra função.

Empresa de pesca mesmo, não tinha nenhuma. Então depois, a partir daí, começaram a vir os catarinenses para cá, porque a pesca deles já era industrial e de grande porte. Começaram a ver que em Cananeia tinha peixe demais, muito peixe. Começaram a vir pouco a pouco, e começaram a inchar a população de Cananeia. Porque eles vinham com um barco e depois vinha a família e comprava casa. E virava um grande pescador, porque eles traziam um barco de lá, e não aquele barquinho nosso, local. Ali no Morro São João ${ }^{65}$ teve uma empresa no argolão $^{66}$ da Olaria $^{67}$ que trabalhava com isso. E depois disso, aqueles espaços foram comprados para trabalhar com peixe, para fazer a compra do peixe por empresas grandes. Quando começaram a chegar esses catarinas, eles começaram a entrar e fazer essas coisas. E não tinha onde o povo daqui trabalhar, só tinha o argolão que tinha alguma coisa. Quem construiu um espaço depois foi por forças próprias.

Por exemplo, quem construiu um espaço de pesca no centro da cidade foi o Helinho... a Miami. A Golfinho ${ }^{68}$ era outra empresa que já acabou faz tempo. Essa Golfinho era lá no Argolão e também trabalhava com peixe. Mas ela não avançou. Quem cresceu foi o Helinho. É Ismael Coelho, o nome dele. Ele construiu a Miami Comércio e Exportação de Pescados, uma indústria de pesca, não só local, para vender no Brasil, mas também para exportação. Ele construiu um terminal, um ponto de pesca tipo um Ceagesp só dele, para parar só os barcos dele. Efez uma fábrica de gelo também, porque

\footnotetext{
${ }^{64}$ Um hotel de luxo construído pelo governo estadual nos anos 1970, com suítes e piscinas de frente para o mar e está abandonado em Cananeia. http://sao-paulo.estadao.com.br/noticias/geral,tj-ve-corrupcao-emhotel-apos-16-anos-imp-,1030912

${ }^{65}$ Bairro de Cananeia próximo à área de concentração de peixarias e embarcações.

${ }^{66}$ Próximo ao entreposto de pesca e do Morro São João em Cananeia existe o "Argolão", local de valor histórico para Cananéia por preservar os argolões de ferro onde as naus eram amarradas durante a colonização. In: CHIQUINHO, Cléber Rocha. Saberes Caiçaras - A cultura Caiçara na História de Cananéia. p.47.

${ }^{67}$ A Olaria existia atrás do Moro São João e confeccionava panelas, potes, cuscuzeiras, etc. In: idem, p.47

${ }^{68}$ Empresa de pesca industrial que existiu em Cananeia.
} 
sabe que precisa disso. E o que aconteceu? Ele acabou virando um grande comerciante sábio. Porque o Ceagesp parou por um grande tempo com a máquina de gelo, e o pessoal já ia buscar gelo no próprio Helinho. E ali, ele dá emprego para quantas pessoas hoje? Eu não sei exatamente mas acho que é acima de 500 pessoas. Outra opção em que o pessoal hoje trabalha é no serviço público, que aumentou nessa época mas ainda são poucas vagas. Em setenta e cinco, setenta e seis foram terminando essas obras todas. E a partir daí morreu essa história do progresso. Depois desse progresso era: agora a gente vai avançar. Mas não avançou muito para situação dos pobres, né? Avançou para cão gordo.

E para mim ficaram alguns elefantes brancos, na verdade, como o hotel Glória, Quarentenária, etc. Então quem quis entrar na área de pesca industrial e aprender, começou a ser funcionário de Helinho. Eles têm tantos barcos que direto estão fora, no mar aberto, com funcionários dele. Ele tem muitos funcionários. A juventude está toda entrando na pesca, trabalhando para ele lá fora direto. Tem outros, mas ele é um grande investidor nessa área. A partir daí começam a achar que Cananeia se desenvolve, mas ela sofre. Eu não sei dizer um nome, uma definição para isso. Até que no começo, funcionaram bem essas benfeitorias. Mas para ter um progresso, elas tinham que ter uma norma para funcionar, tinha que ter uma ajuda do governo para fazer, ter funcionários e se voltar também para a pesca artesanal.

Quando nos tempos passados, como eu contei, em que a gente entrou nas áreas para trabalhar com as comunidades, pudemos perceber que muitas são comunidades pesqueiras. Mas quem era pescador artesanal geralmente não tinha barco próprio, trabalhava em barco de alguém que não era pescador ou de funcionário público. A colônia de pescadores ${ }^{69}$ sempre esteve na mão de funcionário público, por exemplo. Ela nunca esteve em mão de pescador. Nunca. E a partir disso, o Padre João também começou um movimento com os pescadores.

O Padre João falava o que tinha que falar na lata, na cara assim. O que ele achava que estava incorreto, ele falava. Ele falava nas suas missas, também. Tinha grupos que iam assistir o Padre João em missa, para ver se pegavam ele depois. Teve uma vez que um grupo político armou para pegar o Padre João para bater, para matar e acabar com ele na Igreja, logo após a missa. Entraram e fecharam o Padre João dentro da sacristia, um grupo de homens e tal. Eu não preciso citar nomes porque todo mundo

\footnotetext{
${ }^{69}$ Colônia de pesca Z9 Apolinário de Araújo, entidade que, dentre outras funções, representa os pescadores de Cananéia junto aos órgãos da categoria.
} 
sabe. Mas é porque o Padre João sempre falou das questões políticas, do município e dos trabalhos que uma prefeitura deveria fazer. Ou, que não estava chegando nas comunidades isso e aquilo. E quando vocêfala isso, o político fala: caramba, por que ele está falando isso? Ele é contra mim? Não, ele está falando de uma gestão que não está trabalhando. Por exemplo, cada gestão tem um departamento, e esse departamento, conforme quem você põe lá, você está acabado.

Às vezes o prefeito pode até não ser tão péssimo, tão ruim. Até porque, não está na mão dele a ordem de fazer tudo. Mas está na mão dos departamentos. E se no departamento tem uma boa pessoa e que está preparada, a cidade anda. Se ele tiver uma pessoa com alguma forma de tirar vantagem, aí é um problema. Então sempre teve isso em Cananeia. E sempre teve ligação de prefeito com polícia, com Fórum e essas coisas todas. E sempre tentando alguma coisa para tirar o nome deles, para que eles pudessem continuar punindo a população, tirando da população alguma coisa. E eles estavam sempre se safando e saindo. E o Padre João sempre foi um homem que falou as coisas, sempre dizendo o que não estava bom. Mas o que estava bom, o que estava funcionando, o Padre João também falava. Isso chegou aos Conselhos Municipais, e a gente achou de grande importância. Porque agora a população entrava de modo forte no meio das instituições.

No caso da pesca, teve gente que quase morreu por causa disso. Teve um grande pelego daqui, por exemplo, que só perto da morte cumprimentou o Padre João. Ele antes pegava todos os pescadores. Os pescadores trabalhavam para ele, e ele dava tudo. $\mathrm{Na}$ hora de pegar o valor do dinheiro, já estava com débito com ele. E se o cara trouxe pouco, ele somava tudo e via o valor e falava: tem muito pouco para você. Toma aqui. E o pescador sofria demais, demais! Porque eram diversos pescadores que trabalhavam pra ele, o resto trabalhava apenas com canoa. Você não via esses barcos que você vê hoje. Nesse tempo a gente não via um barco próprio. Por quê? Quanto custa para ter um barco próprio? Daquele tamanho ali, é muito caro. Quando a luta foi para a colônia sair da mão de quem não era pescador, o Padre João foi para o fórum. Foi brigar pela colônia. Porque os grupos que estavam lá não representavam os pescadores.

Quando falo em Padre João, não era só ele, era uma equipe de pescadores artesanais que já estavam preparados para fazer esse trâmite todo de ir atrás, de buscar, de falar, de organizar, de ir em cada comunidade e fazer pesquisa sobre quem é pescador e desde quando ele pesca. Foram pesquisas que o Padre João fez. Até que se organizou o dia de uma eleição, porque que numa das eleições anteriores eles não estavam 
totalmente organizados e perderam para outro. Mas a briga era por aquilo: quem está lá, não é o nosso representante. Porque até na Colônia de Pescadores as coisas da pesca eles sófaziam para quem eles queriam. E aquelas pessoas que queriam, muitas vezes não eram pescadores, eram mais profissionais de outras áreas que estavam querendo fazer algo para ter uma boa vida. Os grupos dos mais necessitados não tinham esse acesso, eles estavam sempre trabalhando para esse grupo com dinheiro.

Então lá por oitenta foi feito um grande trabalho, e foi aí que a colônia ganhou a eleição de fato. Foi o José Carlos Cubas, o primeiro pescador presidente com a equipe. E realmente, um homem com uma situação de conhecimento de água e mar, de espaços e de ponto de pesca, é um homem que tinha tudo. Esses homens são homens com muita sabedoria. E ele, a partir de oitenta, nunca mais saiu da mão dos pescadores artesanais, jamais saiu. Hoje eles correm o risco de não cuidar do que foi conquistado... Esse ano foi um ano muito difícil, porque tinha um grupo de pescadores artesanais que estava querendo mudar, que não estava gostando muito do grupo atual. Fizeram uma briga, e isso foi parar no nível da justiça também. Mas mesmo assim, houve uma organização em que o pescador começou a ter o seu lugar e o seu próprio representante.

O Padre João começou a fazer projetos para melhorar a colônia, na Holanda. Inclusive, ele fez um projeto para construir aquela peixaria no Ceagesp. E, também, um projeto de um caminhão frigorífico para peixe. O objetivo era fazer com que a colônia não vendesse peixe só aqui e vendesse em outro lugar. Sem atravessador. A partir daí o pescador ia entregar tudo na própria peixaria. E os caras querem matar quem? Não querem matar o pescador, querem matar o Padre João. Quando ele começou a organizar dessa forma, veio uma pessoa para ser motorista, para ser funcionário da Colônia de Pescadores. Ele também aumentou a Colônia para ter um espaço onde ficaria um carro guardado na garagem.

Numa parte da Colônia o Padre João fez um espaço para cestas básicas para os pescadores comprarem direto lá com um preço muito abaixo do mercado. Essas coisas são tão grandiosas para um local como Cananeia... Fazer uma coisa dessas é criar uma noção de empreendimento tão grande, de você saber que você é capaz de fazer. E não é o Padre João que punha a mão, ele organizava tudo lá na casa paroquial. Mas quem fazia eram eles, os pescadores. Ele dizia: Quem vai fazer são vocês. Ou seja, ele ensinou uma obra muito grande para esse pessoal.

Em setenta e cinco nasceu a diocese de Registro, então deixamos de fazer parte da diocese de Santos. A partir daí, todo trabalho passa a ser através de um bispo local, 
que era o Dom Aparecido José Dias ${ }^{70}$. Ele era um bispo que já era presidente do CIMI, Conselho Indigenista Missionário. E por ser um bispo do CIMI, era um bispo muito ligado nas questões da terra, nas questões locais. Ele falava: eu quero um grupo de padres que trabalhem nessa área. O CIMI estadual descia direto aqui. E sabiam que aqui tinham muitos lavradores e que o pessoal que trabalhava nessas áreas tinha problemas de terra muito graves. Quando passa a ter uma Diocese com a chegada do bispo Dom Aparecido José Dias, ele passa a organizar, com os padres, religiosos e seminaristas, como iria ser o trabalho aqui no Vale do Ribeira. Como atender as paróquias. Ele dizia: para onde vocês vão, irão encontrar exatamente situações que nós já conhecemos e é a mesma para muitos, que são as questões de terra. E um grande problema ligado a isso é a questão ambiental.

Nessa época a questão da terra e do meio ambiente era toda uma problemática. Algumas eram áreas já decretadas pelo governo com alguma forma de restrição. Ou eram Parque, ou outra área de proteção ambiental do governo. Então as populações, sejam elas populações tradicionais caiçaras, sejam ribeirinhas, comunidades quilombolas, sejam elas indígenas, elas estão próximas da água. Próximas aos rios, mares. Então todas estão próximas daquilo que o governo limita, onde você não pode habitar aquele espaço. Mas esses espaços todos já são milenares, de vida, de vivência. Então pensamos: como é que vai ser feito, como vamos trabalhar para organizar, para que todo o nosso povo que mora nessa localidade possa se organizar para se defender, para mostrar o que tem e o que não tem, mas está na memória? Também se preparar para falar assim: nós somos impedidos de mexer, de plantar roça, vivemos em um espaço muito pequeno. Mas só que hoje a cada tempo ou a cada semana, aparece um tal doutor por aí mostrando que aquilo passa a ser terra dele.

O bispo pediu para que o Padre João fosse orientado pelo Padre Teodoro ${ }^{71}$ que trabalhava em lugares que eram bravos nessa história de terra. Registro, Sete Barras, Juquiá, Barra do Turvo, Eldorado, Cananeia... Eram locais em que os grileiros vinham e matavam muita gente. O bispo tinha um desenho do mapa do Vale do Ribeira na sala dele, na entrada, onde ele tinha as cruzes de todos os mortos. Os agentes pastorais, que eram todos ligados na luta, quando alguém morria, punham uma cruz lá: morreu por

\footnotetext{
${ }^{70}$ Ficha do DOPS, Departamento de Ordem Política e Social, de Santos, do bispo de Registro Dom Aparecido José Dias.

http://www.arquivoestado.sp.gov.br/uploads/acervo/textual/deops/prontuarios/BR_SP APESP_DEOPS SAN_P003676 01.pdf Acesso em maio/2016.

${ }^{71}$ Theodorus Petrus Bruin, pároco de Miracatu -SP, também no Vale do Ribeira.
} 
essa causa. Então tinha tantas cruzes que a gente via e falava: nossa! Então o Padre João teve que começar um grupo muito rápido na questão da terra, se ajuntar com o pessoal de cada lugar e juntar vários advogados. Principalmente o Doutor Antônio Telegisnki nessa luta. E formaram um estudo muito grande. Não sei se é estudo topográfico, mas é um estudo de documento das terras para verificar se era verdadeiro aquilo que os grileiros estavam mostrando.

A partir desses muitos estudos, foi mostrado que tinha muita coisa em cartório que não era conforme o que estava lá, sabe? Que não era verdadeiro. Lá existiam posses milenares. E como é que pode ter, de repente, um cartório que faz um documento de alguém como morador, como dono dessa terra? E era esse o problema. Essa área do Itapanhapima ${ }^{72}$ para lá, era muito grande. E, de repente, estava um dono lá. O Padre João foi para São Paulo para conversar com um que falava que era dono dessa área, para falar e explicar a situação, dizer que lá sempre foi área de morador tradicional. E explicou que esses donos só deveriam doar a parte dele e pronto. Explicava que o dono tinha que fazer isso, ou a briga ia ser muito grande. O nome da empresa que comprou é Sulcar $^{73}$.

A gente lembra quando o pessoal contava que ia lá e via essa placa. Até tem foto dessa placa da empresa. Tem, mas não vou achar fácil no meio de tanta coisa. Mas sei que tem foto da nossa ida lá. Nós tivemos que reunir toda a documentação dos moradores e tinha que ser de cada um dos lugares, de cada processo, como, por exemplo, do Retiro ${ }^{74}$, ou quando a gente tinha que ir lá em Santa Maria, no Taquari ${ }^{75}$. Era muita coisa... O pessoal falava assim: mas demora muito, pode demorar anos. E ele tinha que explicar para o povo que o processo podia demorar anos, mas que o caminho era esse. O caminho é: nós não arredamos o pé, somos lavradores, mantemos as nossas roças. São pequenas roças de tamanho, mas vocês têm que se manter firmes.

Então era uma coisa que você tinha que trabalhar na documentação e ao mesmo tempo trabalhar a cabeça das pessoas. Porque eles achavam que levavam o papel ali no cartório e pronto, e eu sou o dono. E não é assim. É um processo que pode durar muitos anos. E da forma como os moradores vinham contar, percebemos que era uma junção de problemas: era o Lisboa grileiro do lado de cá, era a Sulcar do lado de lá, que pegou

\footnotetext{
${ }^{72}$ Hoje parte da área que se transformou na RESEX- Itapanhapima.

${ }^{73}$ No processo consta como Agro-Industrial Sulcar Ltda, com sede à Avenida Paulista, 1439, 9 andar.

${ }^{74}$ Área de moradores que faz parte da RESEX Itapanhapima.

${ }^{75}$ RESEX Taquari.
} 
uma boa parte. Lá bem perto do Ariri, o Alfredo Sens... O famoso Alfredo Sens. É famoso e esse é um dos que faziam ameaça de morte ao Padre João. Nessa época do Padre João, o Doutor Antônio veio inclusive no local, visitar a região. Nós íamos com muita gente, porque sabíamos e tinha notícia que sempre tinha alguém no meio do mato para matar Padre João. Ea gente sabendo disso... Sempre tinha alguém que sabia e avisava. O Padre João tinha uma programação do mês inteiro. E para saber onde o Padre João estava, não precisava ir lá para conversar com ele, bastava ler nas comunidades e na Igreja onde ele estaria no dia tal e tal.

Então, qualquer inimigo não precisava falar com ele, olhava isso, anotava e passava lá. Isso foi quando começamos a fazer a documentação, o levante e a conversar com as pessoas. A gente foi nos locais onde tinham os grileiros e a gente via eles com espingarda na mão para assustar a gente. E o Padre João falava que precisava entrar. É uma história, uma coisa incrível. Teve uma vez que a gente até teve que tirar o Padre João escondido daqui, levar para Registro. Porque estava muito pesada a questão de quererem matá-lo. Mas ele tinha sua programação e falava: nós não vamos deixar de ir. Ele falava: Cida, você vai. Você e uma outra moça. E eu pensava assim: meu Deus do céu! E se o cara está esperando o Padre João? E o caminho para o bairro Santa Maria eram caminhos difíceis. Quando ele falava que éramos nós que iríamos, eu nunca falava nada para minha mãe. Esse pessoal aqui de casa, nunca sabia nada de mim. Não sabem até hoje.

Mas eu falei: está bom, Padre João, eu vou. E eu pensava: em que ponto de mato será que eles estão, né? E se eles quiserem matar a gente? Se eles têm tanto ódio do Padre João, quem estiver no lugar do Padre João, é um inimigo deles. E se matassem a gente estariam mexendo com ele. Era um risco. Eu passei muito risco com o Padre João. Quando ele estava na cidade e nós saíamos, sempre tinham seis ou sete pessoas ao lado dele. E ele era grande (risos). Era uma coisa interessante. Na época, a gente já combinava: Quem vai com o Padre João? Porque tinha outras lutas de outros companheiros que também precisavam do apoio. Então nós éramos um grupo de apoio geral. Não era um grupo em que um falava sim e o outro não. Então o Padre João saia conosco do lado. E para matar o Padre João, iam matar a gente também. Poderia acontecer e, quando íamos para outras regiões, eu ficava com medo. Ariri, principalmente, era terra de jagunço. Lá era um lugar muito perigoso. Eles já se matavam entre os jagunços. Tinha o jagunço maior que queria matar o Padre João, ele era famoso esse cara. Não me lembro o nome dele. Era um baiano. Teve um que matou 
ele... E tinham jagunços do Ariri que tiravam sarro do padre. Andavam direto com facões, resolveres e espingardas no meio do povo assim. Os caras eram perigosíssimos. Tem processos, mas vai ser muito difícil eu achar o processo de cada um.

Nessa época, uma parte das áreas não era parque ainda. Essa área do Retiro em Itapanhapima, que foi vendida para a empresa Sulcar, não era considerada parque. A ilha do Cardoso sim, mas essa área não. Então os grileiros todos, eles começaram a invadir pelas estradas. A estrada do Ariri é o ponto em que eles têm acesso para entrar nos demais bairros, pelos fundos das áreas. Por isso que no caso do Retiro, Itapanhapima, Bom Bicho ${ }^{76}$, esse grupo todo ali, de repente começou a ver alguma coisa no fundo dos seus terrenos, porque a casa deles está num lugar, mas tem que andar quilômetros para chegar aonde é o limite da terra. De repente chega lá, eles já encontram algo que diz que alguém entrou por trás, e começaram a encontrar outras coisas que foram usadas para demarcar dentro da área dele. Então teve que ser feito um processo em conjunto.

Fomos começar a ver como fazer um processo de recuperação da posse da terra. Tem que ser um só, para facilitar a junção, não só do povo, como também de toda documentação e da facilidade de você lembrar isso, aquilo e aquilo e montar o grande quebra cabeça. Como eles entraram por trás na área, começaram a trazer coisas escondidas. Começaram a falar na região que era o Ademício ${ }^{77}$ quem comandava isso tudo. Talvez não era ele quem invadia, mas era ele quem comandava. E cada vez mais eles invadiam e foram colocando mais coisas na área e a gente foi subindo. Até então a gente não ia até o limite do terreno, porque é longe, não tem porque você ir para lá, e nem os moradores precisavam ir diariamente. Mas quando a gente foi de grupo, de conjunto, isso foi assustador para a família da mulher de Ademício. Eles eram moradores de onde a gente passava com a caminhada, e eles tinham comunicação com Ademício direto. Os pais dela estavam lá na casa quando a gente passava ou voltava. Então quem passou ou não, eles podiam todos contar para o Ademício. A gente fez essas organizações assim, de tentar essa luta constante, até chegar esse dia do processo. Foi chamado ele com a mulher como réu, e os outros quatro moradores que representam os outros lugares, e nós, como testemunhas, fomos ouvidos. Veio só um representante da "Sulcar" para falar, mas a "Sulcar" mesmo como grupo, não apareceu.

\footnotetext{
${ }^{76}$ São as três áreas que compõem a RDS Itapanhapima.

${ }^{77}$ Segundo os relatos, Ademício Bernardo da Silva é o nome de quem se casou com a filha de um dos moradores do Retiro e conseguiu uma procuração que o permitiu vender toda a área da comunidade.
} 
A gente fez a declaração do padre João que sabia de todos os históricos. Eu, como trabalhava na casa paroquial, no atendimento de todas as questões do povo, de todos os locais de Cananeia, sabia do histórico de cada um, que dia que ele veio, que horário ele veio avisar. $O$ advogado me perguntava assim: o que a senhora acha quando foi dito aqui, que as pessoas entraram por trás, pelos fundos da área? Eu respondi: olha doutor, na minha visão eu acho que quem entra pelos fundos é sempre ladrão. Porque quem entra pelo escuro, fundos, escondido, só pode ser ladrão. Não é família, não é do bem, é alguém trapaceiro, que quer roubar, que quer colocar medo. E o Ademício do lado me ouvindo, ele me detestava. Até hoje ele nunca gostou de mim, ainda mais quando eu declarei que ele era um ladrão que pulava pelos fundos. Eu fiz essa declaração e depois veio o Zé Carlos $^{78}$, também, e contou os fatos todos. O processo deles foi para frente porque era muito absurdo ter um cara que fez uma firma para ele mesmo, pegou um projeto e ele mesmo construiu uma casa em cima de uma fazenda que não é deles ${ }^{79}$.

Na verdade o Dr. Antônio se cercava com documentações, lógico, ele era conhecedor do meio ambiente do estado de São Paulo. Então com o que ele conhecia dessas áreas todas, não precisava de muita coisa para falar. Quando deram o veredito final, eles perderam, e nós fizemos uma grande festa. Quando a gente relembra aqueles cortes de arame... foi muito bonito. Nós fomos naquela caminhada, cortando todos os arames farpados. Eu falei: vamos levar um pedaço de arame farpado para a celebração da missa. Pegamos flores no caminho, encaixamos flores lindas, de libertação, de que não tinha mais nada para ter medo, cortamos tudo. Tivemos coragem e fomos lá, e se eles colocassem lá de novo, nós iríamos cortar de novo. A gente rezou muito por isso também, com a intenção de trazer o histórico pesado da vida do povo para colocar na mão de Deus e falar assim: esse povo sofre essa situação. E a gente falava: é assim que temos que nos comportar como cristãos, como seguidores, como aqueles que sentem a presença de Deus na vida e que tem essa fé que Deus também está conosco, está com os pobres. Alguém pode dizer: vai dizer que o pobre vai ser sempre feliz da vida na Bíblia? Não, não está escrito isso na Bíblia, mas está escrito, deles é o reino dos céus. Então quando fala isso, Deus diz que deles é o reino dos céus, então essas pessoas vão ter garantia de vida, possibilidades e chances para ir para frente.

\footnotetext{
78 José Carlos Godoy, um dos moradores da RDS Itapanhapima.

${ }^{79}$ Segundo recibos que foram anexados ao processo, Ademício é qualificado como empreiteiro de obras e dono de uma empresa de material de construção que vendia produtos para a Sulcar. Portanto ele mesmo retirava as mercadorias e coordenava os trabalhadores da empresa contratados para construir a sede da "Fazenda Retiro" nome dado à área grilada.
} 
Então a gente tem sempre uma forma de trazer essa discussão para uma celebração, ou para um momento de reza nas casas, um momento de falar com Deus. A gente sempre trabalha e fala sobre alguma coisa em que a gente já conseguiu dar um passo adiante. Mostrava que um passo já demos, já passamos essa fase, estamos na fase final, ou ainda no meio. Mas tudo isso já ensinava o povo a se manter fiel. Por exemplo, teve outros processos aqui em Cananéia de terra de lavradores também, onde a gente tem o caminho de servidão, sabe? É um caminho antigo, onde todos passam por ele para seguir para outros caminhos. Chama-se caminho de servidão. Caminho único, isso todos os lugares têm. Se você precisar entrar nesse trecho, alguém te dá chance de passar no caminho de servidão porque é um caminho livre, aqui ninguém pode fechar. Todos os antigos, todas as pessoas que são de qualquer área de sítio, vão dizer. Os mais antigos, porque hoje as crianças não conhecem isso, o que é um caminho de servidão, porque hoje não tem mais. Como o caminho que existia entre o Taquari e o Itapanhapima. É o caminho onde todo mundo anda diariamente, é um caminho que vai e volta. Você até poderia formar um novo caminho, mas nós temos esse caminho de servidão.

De repente vem alguém que compra um lote lá, porque o morador vende um pedaço dele, e o que o cara faz? Ele vai lá e começa a construir em cima do caminho de servidão e isso é contra qualquer norma dos povos. Teve pessoas que fizeram e veio um aviso imediatamente para o padre João: olha, padre João, fulano aqui que é um cara ruim - sempre é um cara ruim que está na frente para colocar medo no povo - está fechando nosso caminho de servidão. O padre João, falava: derruba tudo aí, caminho de servidão nunca ninguém pode fechar. Sempre orientava assim: você não pode deixar, se começou a colocar hoje, vá lá, derrube e faça um B.O. Olha, hoje o senhor tal passou com blocos em cima do nosso caminho de servidão, o caminho que todo mundo necessita para chegar. Porque se ele fecha esse caminho, eu não posso mais passar para minha casa. Eu não tenho mais como chegar no meu lugar que é lá na frente, meu espaço, eu tenho que começar a fazer uma picada ${ }^{80}$ por aqui, mas aí estou fazendo picada no terreno de quem? Estou entrando no terreno de uma ou outra pessoa. Então não é justo que nós, filhos daqui paguemos por causa de uma má conduta de alguém que só vem para fazer mal, para roubar. Queremos é ter a posse, então umas das brigas é manutenção de posse do caminho da servidão para população tradicional, morador antigo, que tem seus

\footnotetext{
${ }^{80}$ Termo usado para abertura de caminhos na mata.
} 
ancestrais na história daqui. Então é aquele caminho em que todos têm que passar e ninguém pode fechar nunca.

Foram diversas vezes que tentaram fechar o caminho de servidão e foi um dos processos que o padre João entrou. Apoiado pelo CPT, Conselho Pastoral da Terra, e pela diocese de Registro. Conforme ia seguindo, o padre João fazia um relatório para o bispo e também para quem ajudava a manter um agente de pastoral, como era chamado uma liderança que não tinha medo e que ia em cada cidade que tinha problema de terra para levantar documentos, trazer para o advogado, para pagar advogado também, para tudo isso. Tinha um projeto fora do Brasil que era com a Trocaire da Irlanda. Lá ele apresentava um projeto para que pudesse custear um agente e um advogado, para que houvesse esses processos todos com a Igreja tomando a frente, a partir de seus pobres $e$ dos leigos. E cada vez o padre João fazia um relatório, por exemplo, com os gastos, narrando os acontecimentos, em quais locais tem problema de terra em cada cidade. Cananeia tem esse, esse e esse. Barra do turvo tem, Eldorado tem, Registro tem, Sete barras tem, Juquiá tem... então ele dava esses dados. No outro momento ele fazia um relatório dizendo assim: em Cananeia, depois de um ano, ganhamos dois processos, restam tantos. Era uma coisa de você devolver para a instituição que está colaborando ver o andamento das coisas. E também estarem o tempo inteiro sabendo como é isso, que aqui tem um povo que foi, ganhou uma liberdade para viver melhor. Até porque o viver melhor é continuar assim como está.

Todas as pessoas que saíram dos seus lugares porque virou parque, elas tiveram que passar a viver em outros lugares, que não eram grandes áreas, mas tinham uma terra que dava para sempre plantar alguma coisa. Pequenos pedaços de área que davam para plantar, feijão, arroz, milho, a mandioca, para fazer a farinha. Plantavam em quantidade menor, mas plantavam. Acontece que se essas pessoas perdem tudo, elas perdem a chance de renovar sua semente mais vezes, ela não tem como se auto sustentar, ela tem pouca coisa até para troca. Por isso, mesmo que ela passe a ser um pescador, passe a ter outra definição, ela nunca deixa de usar totalmente o pequeno trecho de terra que ficou para ela, para plantar sempre e mexer com alguma coisa. Então o morador tradicional sempre vai estar usando o espaço que foi definido para ele, mesmo ele sendo pescador. Porque ele é lavrador também. Ou seja, aqui, mesmo ele sendo pescador, ele não é só pescador, ele tem um segundo complemento de renda, de subsistência, que é o espaço de vida dele, que ele tem para plantar e colher, e isso é geral para todos. 
Então cada vez que o pessoal ganhava suas áreas de volta, era uma coisa importante, para saber que eles podiam plantar em algumas partes. Porque a polícia florestal já ia com muitas multas em cima, se vissem queimadas ou corte para roça. Então eles teriam que fazer um pedido, uma licença, de uma área ainda menor. Tudo foi criado assim, foi fazendo podas na vida do morador, e ainda tem a polícia florestal que pune e multa. Essas multas vieram muitas vezes para o padre João defender. Todas as multas eles vinham trazer primeiro para o padre João, porque eram multas caras. Por exemplo: eu fui pego, na minha canoa, porque era uma malha ${ }^{81}$ diferente. Então a pessoa fica com a malha presa, o peixe do dia preso e com uma multa alta. O padre João tinha que defender, para voltar a malha, o peixe já não ia pegar, porque passava um dia dois, não adiantava mais... mas ia defender para não precisar pagar a multa também.

Ele ouvia a pessoa, que falava por horas se precisasse. Dizia: conta os fatos como acontece. Porque você usa a malha lá? Eles diziam: padre o nosso peixe não pega na malha certa, tem que pegar nessa. Porque existe a lei das malhas no Brasil, só que a que eles colocaram na lei são malhas do nordeste que não cabem nas nossas águas. Porque os peixes são diferentes, e o tipo de malha para o qual a lei foi pensada foi para peixe que tem lá, mas não tem aqui. E eles são sempre pegos por causa disso. O padre João tinha o código civil do lado da bíblia, porque toda hora ele usava, olhava as questões de direito, a constituição brasileira.

Então ele fazia um papel, definia pontos de lei para defesa, com a identidade daquela pessoa, dizendo que ele é um pescador, um profissional artesanal, e é parte da população tradicional local. Fazia tudo isso com um documento de três vias, e falava: volta lá, e protocola esse documento, eles vão ficar com duas, e o terceiro sempre fica com o senhor, e aguarda a resposta. Assim era para o INSS, assim era para a pesca, para roça, todo mundo vinha. E sabe o que a polícia falava? Olha, eu fui lá, você está sendo multado por causa disso, porque roçou um mato que já estava no tamanho tal. Pega esse papel, vai para o padre João e fala para ele defender você. Porque eles sabiam que jamais o pessoal nosso iria saber fazer um documento como o padre João fazia. Nem eu mesma saberia fazer esse documento. Estudando o código civil, as leis brasileiras, as leis da mata atlântica, porque ele trabalhava no SOS Mata Atlântica ${ }^{82}$, trabalhava com o Dr. Antônio, o advogado que também passava informação e com isso agia muito rápido.

\footnotetext{
${ }^{81}$ Rede de pesca.

${ }^{82}$ Organização não governamental fundada em 1986 e que atua no bioma da Mata Atlântica até os dias de hoje. www.sosma.org.br Acesso em janeiro/2017.
} 
Então a própria polícia já sabia isso, e o próprio advogado já chegava e falava: João, a facilidade de trabalhar com você é muito boa. Você fala que tem cinco processos que vão nascer, e eu tenho que descer para cá para ver esses processos, mas quando eu chego aqui, todos os cinco processos já estão montados. Inclusive falando de que livro é, a fonte de onde foi, ele já descreve tudo como defender o cara, eu não tenho que praticamente montar nada, eu só tenho que ler com você e a pessoa, e ir colocando a parte do advogado, a parte mais burocrática. O advogado ia para dar a entrada, agora quando era para protocolar documento, incluir algo novo, o padre João ia ou eu, a gente tinha acesso ao processo.

Não é que ele era advogado, mas para mim ele era filósofo, era historiador... eu falo, porque ele era um padre que fez todo um estudo de toda a área da Igreja aqui, um preparo com história, com ciências... Mas eu acho que ele era também um poeta, era um arquiteto, tudo o padre João entendia um pouco. Quando ele estava de férias, ia para outros países para trabalhar na construção de casas. Então o padre João aprendeu muita coisa com trabalho voluntário. A minha casa ele desenhou rapidinho. A casa dele ele desenhou como queria, não precisou de engenheiro para vir desenhar: o desenho está feito aqui, eu quero assim. O tipo de madeira tanto para trocar na Igreja, capelas, o padre João sempre escolhia o melhor produto para que durasse longos anos, para que não precisasse tapar ali com qualquer madeira, para que durasse algumas chuvas. Cananeia é um lugar que chove demais, muito, muito. A região tem um nível de água em tempo de chuva muito grande. Já mudou nos últimos anos, o clima está mudando, as chuvas não são mais no tempo certo.

De vez em quando o padre João viajava para terra dele de férias e ficava uns quatro meses. Quando ele não estava, era eu. Eu falei que eu quase aprendi um pouco de advocacia por causa disso. De ficar tentando trabalhar com essas questões da terra no Vale do Ribeira. Toda essa história foi contada no último relatório que o padre João fez para a Trocáire em 2001, porque ele faleceu em 2008. Ele deu os últimos dados da CPT (Comissão Pastoral da Terra) pedindo a renovação e continuidade do convênio da CPT com a Trocáire para as próximas gestões. E renovou. Então ele fez todo último levantamento dos processos de cada lugar. Em Cananeia, só faltavam dois de todos, em 2001, que era o de São Paulo Bagre ${ }^{83}$ que era essa questão do caminho da servidão, que a gente ganhou e o resultado saiu um pouquinho antes dele morrer. Ainda soube desse

\footnotetext{
${ }^{83}$ Bairro rural de Cananeia.
} 
fato antes da morte dele, poucos dias antes veio um aviso do Fórum. Foi favorável a uma família que tinha dez filhos e que não tinha como terminar a casa deles, por causa desse problema. Então ele fez essa última coisa, sobre a CPT mostrando que até aqui todos esses processos tiveram como resultado o aval positivo. Os que ainda estavam em andamento, então era outra coisa.

O padre João era muito organizado na sua vida, ele organizava muito bem o histórico de cada pessoa. Quando ele fez o levantamento da vida de Ezequiel Oliveira ${ }^{84}$, por exemplo, ele foi lá e fez uma pesquisa: Ezequiel, dados dele, quantos anos tem, casou ou não, quem são seus filhos... tudo para fazer a árvore genealógica dessa família. Então quando ele fez isso em 1970, hoje esse histórico vale como documento de terra para o ITESP (Instituto de Terras do Estado de São Paulo), como valeu como documento para carteira de pesca. Quando foram colocar luz no Agrosolar ${ }^{85}$, o pessoal não tinha nada de registro das pessoas, e eu tinha esse levantamento da pesca. Então o funcionário falou: não importa, pode ser. Você tem de fulano e beltrano? Eu olhei tinha quatro folhas, ele já fotografou e disse: para nós já basta. Então você vê, você toma nas mãos os dados de uma pessoa, você guarda, documenta, copia, arquiva tudo. Esses documentos depois de tantos anos, ele passa a ser a única forma de defesa que essa pessoa tem como alguém que seja legítimo morador da terra ou um pescador. E o padre, realmente ele teve sempre um caminho, um cuidado, um trato, um amor... a menina dos olhos do padre João sempre foram as populações caiçaras, o meio ambiente, a pesca, a questão da terra e de toda sua problemática, a história de cada lugar, de como era Cananéia para ele.

\footnotetext{
${ }^{84}$ Morador tradicional da ilha do Cardoso

${ }^{85}$ Bairro rural de Cananéia.
} 


\subsection{As comunidades, um padre e a luta por direitos.}

A chegada de Padre João à cidade de Cananéia fez parte de um movimento maior da Igreja Católica na busca por aproximar-se das questões sociais que afligiam as camadas mais pobres da população. Isso ocorreu segundo pressupostos éticos e políticos assumidos por um grupo na Igreja Católica ligado à Teologia da Libertação e também segundo princípios definidos pelo Concílio Vaticano II (1962-1965), que estimulava os agentes pastorais a dedicarem-se à questão mais ampla dos direitos humanos, abrindo um novo horizonte de problematizações sociais. ${ }^{86}$

No Vale do Ribeira, as questões ligadas à Teologia da Libertação estiveram presentes não apenas na figura de Padre João e seus apoiadores, mas em diversas comunidades de Ivaporunduva e Pilões, estudadas por Lurdes Carril ${ }^{87}$. Nesse estudo, a autora demonstra como agentes pastorais e camponeses passaram a influir em projetos alternativos de mobilização social, como é o caso de movimentos agrários que deram origem ao Movimento dos Trabalhadores Rurais Sem Terra. Nascido a partir da luta dos afogados pela Barragem de Passo Real no Rio Grande do Sul, este movimento inaugurou uma nova prática depois de terem sido instalados na Fazenda Anoni graças à compra das terras pela Diocese de Passo Fundo. No Vale do Ribeira, a atuação de religiosos e leigos juntos às pastorais, em especial a CPT (Comissão Pastoral da Terra), ocorre sobretudo a partir dos anos de 1970, em decorrência do acirramento de conflitos fundiários na região que culminam na expulsão de populações rurais de suas terras, transformando-as em "sem-terras, bóias-frias e escravos" ${ }^{8}$. Segundo Iokoi, a ação de programas econômicos governamentais na região, como a criação da SUDELPA (Superintendência para o Desenvolvimento do Litoral Sul, 1969) voltada para a criação de "diversos projetos de desenvolvimento econômico como a ampliação dos sistemas de transportes, eletrificação rural, incentivos fiscais à agropecuária, ao extrativismo, ao reflorestamento e à mineração ${ }^{~} 89$ aumentou a concentração de terras na região ao despertar o interesse de diversas empresas que passaram a adquirir terras para fins de especulação ou criação de empreendimentos agropecuários no local. Outro aspecto da atuação da SUDELPA diz

\footnotetext{
${ }^{86}$ IOKOI, Zilda M. G. Igreja e Camponeses: Teologia da Libertação e Movimentos Sociais no Campo Brasil e Peru - 1964/1986. São Paulo: Hucitec, 1997.

${ }^{87}$ CARRIL, Lourdes de Fátima. Terra de negros no Vale do Ribeira: Territorialidade e Resistência. Dissertação de Mestrado. São Paulo: FFLCH/USP, 1995.

${ }^{88}$ IOKOI, op. cit.p. 108 .

89 Idem, p.108.
} 
respeito à inciativa de promover a regularização fundiária na região por meio da titulação de lotes individuais aos posseiros. A titulação, ao desconsiderar a existência de terras comunais, também contribuiu para agravar os conflitos fundiários na medida em que algumas famílias venderam seus lotes para pessoas de fora das comunidades rurais ${ }^{90}$. Somando-se a esse quadro, a abertura da estrada BR 116 nos anos de 1960, cujo o objetivo era integrar a região ao cenário econômico nacional, promoveu a valorização das terras e foi também responsável pelo aumento da concorrência em torno de produtos agrícolas locais, como o arroz, dado que mercadorias da região sul produzidas com melhores técnicas, passaram a ser vendidas com preços mais baixos na região.

Paralela a esse contexto de modernização econômica conservadora, que promoveu o avanço do grande a capital sobre as terras e recursos naturais da região, a pressão de grupos ambientalistas ${ }^{91}$ sobre o governo do estado de São Paulo permitiu que este, embasado pelo Código Florestal Brasileiro de 1965, expandisse as demarcações de reservas estaduais no Vale do Ribeira e no Pontal do Paranapanema. Já a partir da década de 1960, diversos Parques Estaduais foram criados na Região do Vale do Ribeira, como o Parque Estadual da Ilha do Cardoso (PEIC) e o Parque Estadual do Jacupiranga (PEJ), sendo que ambos afetaram diretamente a população de Cananeia. Entretanto, ao esforço legislativo para proteger o que restava da historicamente devastada Mata Atlântica ${ }^{92}$, não houve correspondência em termos de estratégia planejada para a demarcação dessas unidades, o que se somou ao fato de que grande parte do debate ambientalista estatal ainda se orientava pelas perspectivas físico-química e biológica de estoques de recursos, numa visão claramente economicista da natureza. ${ }^{93}$

Tratando-se de unidades de conservação ambiental voltadas para a proteção integral, os parques foram criados sobrepostos a áreas intensamente ocupada por populações rurais da região, inviabilizando sobretudo a agricultura e o extrativismo nessas áreas. Todos esses fatores agravaram as condições de vida dos pequenos agricultores da região, que passam a encontrar nos trabalhos das pastorais da Igreja Católica, a solidariedade, o afeto e o apoio institucional para enfrentar os conflitos ${ }^{94}$. Sob

\footnotetext{
90 TATTO, Nilto, SANTOS, Kátia Pacheco (ed.). Agenda socioambiental de comunidades quilombolas do Vale do Ribeira. São Paulo: Instituto Socioambiental, 2008, p.08.

${ }^{91}$ Clayton Lino, conhecido militante ambientalista da região em entrevista concedida ao projeto S.O.S Mata Atlântica 18 anos". http://www.bioclimatico.com.br/ Acesso em outubro/2016

92 DEAN, Warren. A Ferro e Fogo - A história da devastação da Mata Atlântica brasileira. São Paulo: Companhia das Letras, 2004.

${ }^{93}$ NEDER, Ricardo Toledo. Crise Socioambiental, Estado e Sociedade Civil no Brasil (1982-1998). p.31.

${ }^{94}$ IOKOI, op.cit.p. 108.
} 
esse contexto, a fundação da Diocese de Registro, em 1975, regida pelo Bispo Dom Aparecido Dias, contribuiu para o fortalecimento da ação dos agentes pastorais ${ }^{95}$. Segundo Maria Ap. Rangel, a militância do bispo em relação aos temas fundiários e ambientais permitiu a organização de um grupo de padres e agentes pastorais que passaram a atuar em diversas cidades do Vale do Ribeira, dentre elas, Cananeia. Foi apoiado por membros da diocese e pelo trabalho pastoral que começou a atuação do padre João 30 em meados da década de 1970.

A cidade de Cananeia encontrada pelo padre João 30, segundo Maria Ap. Rangel, insere-se nesse contexto regional marcado pela violência agrária e a repressão ambiental às populações rurais, denominadas localmente como caiçaras ${ }^{96}$. Segundo nossa colaboradora, trata-se do período do chamado "progresso de Cananeia", marcado pela criação do entreposto pesqueiro CEAGESP (Companhia de Entrepostos e Armazéns Gerais), o Hotel Glória ${ }^{97}$, a abertura da estrada Itapitangui - Ariri (cujo projeto inicial era a integração deste trecho à rodovia BR 101) que corta a área continental de Cananeia até a divisa com o Paraná, a ampliação da rede escolar e a chegada do "catarinas", pescadores proprietários de barcos modernos ou ligados à grande indústria pesqueira, provenientes, sobretudo, de Santa Catarina. Ainda que reconheça alguns avanços, nossa colaboradora é extremamente crítica ao período, destacando que o desenvolvimento econômico vivenciado pela cidade privilegiou os grupos mais ricos e que pouco foi feito em relação às populações caiçaras locais, tanto os agricultores quanto os pescadores artesanais.

Segundo Mourão ${ }^{98}$, a dinamização do mercado pesqueiro local se deu em decorrência da interligação entre o litoral sul e o planalto, mais especificamente, pelo acesso ao grande mercado consumidor de São Paulo promovido pela criação da BR 116, antes acessível apenas pelo precário eixo rodoviário Juquiá- Piedade, construído em 1935. Dessa forma, nos anos de 1960 uma nova onda de pescadores com mais tecnologia e

\footnotetext{
${ }^{95}$ 16/fev/1975 - Desmembrada da Diocese de Santos, criou-se a Diocese de Registro, tendo Dom Aparecido José Dias como seu primeiro bispo; http://www.diocesedesantos.com.br Acesso em fevereiro/2016.

${ }^{96}$ Mussolini, Gioconda. Ensaios de Antropologia Indígena e Caiçara. Rio de Janeiro: Paz e Terra,1980

${ }^{97}$ Hotel construído pelo governo do Estado de São Paulo atualmente abandonado e sobre o qual pesam diversas denúncias de corrupção. "Durante anos, funcionários públicos receberam hóspedes sem cobrar, usaram notas frias para justificar despesas inexistentes e colocaram um vigia para administrar todo o hotel. Tudo isso foi constatado em 1997, mas só agora, 16 anos depois, o Tribunal de Justiça condenou quatro funcionários estaduais pelos fatos." http://cidadeilustre.blogspot.com.br/2013/05/o-caso-do-hotelgloria-estadao.html. Publicado em 13 maio de 2013. Acesso em março/2017

${ }_{98}$ MOURÃO, Fernando Augusto Albuquerque Mourão. Os Pescadores do Litoral Sul: um estudo de sociologia diferencial. São Paulo: Hucitec/NUPAUB/CEC, 2003. p.41.
} 
provenientes do litoral sul do país chega à região atraída pelos estoques pesqueiros do estuário lagunar e do mar aberto da região. Para Diegues:

Em inícios da década de 1960 houve uma ativação das atividades pesqueiras. Novas levas de pescadores "catarinenses" dotados de motor de centro estabeleceram-se na área lagunar e nas praias da Ilha Comprida, pescando também no mar grosso. Nesse período operou-se também uma diferenciação bastante nítida entre os pescadores motorizados que conseguem atravessar a barra e ir pescar no Mar de Fora, selecionando espécies de maior valor no mercado, e os pescadores do Mar de Dentro, que continuaram dependendo dos recursos cada vez mais escassos da lagoa. ${ }^{99}$

Após essa dinamização, as empresas pesqueiras que chegaram à região estimularam o fluxo de pessoas das áreas rurais para a área urbana de Cananeia, que neste momento "desenvolve uma pesca semi-industrial vigorosa, o que reflete na construção do entreposto do CEAGESP no início da década de 1970, e a chegada de várias indústrias pesqueiras" ${ }^{100}$. Como consequência, muitos pescadores tradicionais foram proletarizados pela indústria pesqueira, passando a trabalhar em barcos voltados para a produção em larga escala. Com péssima remuneração, esses trabalhadores chegavam a ficar 20 dias em mar aberto sujeitos a todo tipo de intempérie climática e mecânica. A modernização da pesca na área urbana da cidade foi acompanhada pela "marginalização de boa parte do grupo que havia permanecido na área rural do sistema lagunar" ${ }^{101}$.

Nossa colaboradora afirmou que o processo de marginalização social dos pescadores ocorreu tanto na área urbana quanto na rural, posto que os pescadores que continuavam trabalhando com canoas não eram capazes de competir com as modernas embarcações motorizadas. Assim, muitos pescadores artesanais passaram a trabalhar para atravessadores que possuíam barcos motorizados, sendo submetidos a uma intensa exploração. Essa situação foi identificada pelo padre João, que passou a promover um intenso trabalho de organização dos pescadores por meio da colônia de pesca de Cananeia Z9 Apolinário de Araújo, entidade sindical que, embora oficializada apenas em 1985, já era organizada desde os anos de $1960^{102}$. Dentre suas iniciativas, destaca-se a politização

\footnotetext{
99 DIEGUES, Antônio Carlos. Biodiversidade e Comunidades Tradicionais no Brasil. São Paulo: NUPAUB-USP, 1999. p.06..

${ }^{100}$ DIEGUES, Antônio Carlos. O Vale do Ribeira e Litoral de São Paulo: meio-ambiente, história e população. p.14

${ }^{101}$ MOURÃO, op.cit. p.22.

${ }^{102}$ MOURÃO, op.cit. p.23.
} 
dos pescadores, incentivando-os a assumirem os cargos representativos na colônia, além da angariação de recursos junto a organizações não-governamentais para o desenvolvimento de projetos como a criação de uma peixaria próxima ao entreposto pesqueiro, que permitiria ao pescador artesanal vender seu produto sem a necessidade de atravessadores. Além disso, padre João promoveu ações de assistência aos pescadores, incentivando a regularização trabalhista com a obtenção da carteira oficial de pesca e promovendo ações mais imediatas para aqueles que se encontravam em situação de maior vulnerabilidade social, por meio da venda de cestas básicas a preços reduzidos em relação ao mercado.

Em relação às áreas rurais ligadas à agricultura, cuja pesca constituía uma atividade voltada ao consumo local, uma das primeiras questões com a qual o padre se deparou no município foi a expulsão dos moradores da Ilha do Cardoso, em decorrência da criação do Parque Estadual em 1962. A Ilha do Cardoso possui em torno de $151 \mathrm{~km}^{2}$, sendo por um lado separada do continente pela baia do Trapandé e o canal do Ararapira e pelo outro, banhada pelo mar aberto. Primeiro parque a ser construído na cidade ainda sob a ideologia preservacionista, ou seja, que não permite a presença humana, a população local foi expulsa sem nenhum tipo de ação indenizatória, sob constantes ameaças e investidas do governo estadual para a desocupação da área. A população que resistiu, enfrentou por sua vez a proibição de suas roças tradicionais, sendo esse mais um fator que inviabilizava a permanência.

Para impedir a expulsão desses moradores, padre João, com o auxílio de outros agentes das pastorais, como nossa colaboradora, promoveu um intenso processo de documentação dos moradores da área, buscando demonstrar os vínculos históricos com a terra e embasar juridicamente a luta contra o Estado que se estendeu - e se estende de outras formas - até os dias de hoje. Em relação à área rural continental de Cananeia, segundo nossa colaboradora, um dos primeiros passos do padre ao tomar contato com a realidade local, foi promover uma pesquisa com os moradores das áreas rurais, buscando diagnosticar os principais problemas enfrentados por eles e constituir redes de organização nos bairros, responsáveis pela comunicação entre a Igreja e as populações locais. A partir desse primeiro contato, ele estabeleceu uma agenda de visitas regulares e reorganizou as atividades da Igreja, realizando missas e demais ritos religiosos ligados aos padroeiros locais, como as procissões e festas, buscando agregar a comunidade.

Foi por meio desses espaços religiosos e de visitas às casas das famílias que o padre conquistou o apoio e a confiança da população, passando também a auxiliá-la na 
orientação política e jurídica necessária ao enfrentamento às constantes ameaças ao seu direito de permanência e manutenção de seu modo de vida tradicional vinculado à agricultura, extrativismo e a pesca, tal como na Ilha do Cardoso. Conforme demonstrado pelas narrativas de alguns dos nossos colaboradores, as figuras do Padre João e de Maria Aparecida Rangel são diretamente vinculadas aos processos de luta contra a invasão de empresas e de fazendeiros nas áreas pesquisadas, decorrente da abertura da estrada Itapitangui - Ariri que atravessa o continente. Segundo Sales e Moreira:

\begin{abstract}
A partir dos anos 60 deste século, o Estado, a fim de procurar promover o desenvolvimento da região, inicia a implantação de uma série de obras e infraestruturas, sem contemplar, entretanto, os moradores tradicionais, principalmente no que se refere ao apoio jurídico para as questões fundiárias e à assistência técnica para otimização dos seus processos produtivos. $\mathrm{Na}$ verdade, as ações governamentais determinaram uma valorização das terras, deflagrando processos de especulação imobiliária e grilagem de grandes áreas, restringindo o acesso dos moradores aos recursos tradicionalmente explorados e/ou acarretando sua expulsão. ${ }^{103}$
\end{abstract}

Através das histórias de vida dos colaboradores, tomamos conhecimento da existência de tão importantes personagens da história de Cananeia. Segundo eles, a atuação do padre João e dos grupos de leigos que o acompanhava passava por muitos aspectos da vida dos moradores dos bairros rurais. Cumpriam as cerimônias religiosas, faziam trabalhos de formação, colaboravam com famílias que estavam com dificuldades financeiras, apoiavam a população contra os grileiros e a polícia ambiental, orientando mecanismos de defesa e mobilizando pessoas e recursos. No bairro do Retiro - hoje parte da RDS Itapanhapima - um dos episódios rememorados foi a venda dos sítios dos moradores para uma empresa denominada Agro - Industrial Sulcar. Na ocasião, o padre João foi o responsável por orientar os moradores e, em conjunto com eles, realizar uma ação judicial contra a empresa. O processo, que durou alguns anos, correu no Fórum de Cananeia, local de onde o padre entrava e saía constantemente, e resultou no ganho de causa dos moradores. Segundo nossos colaboradores:

O padre João era nosso amigo, quando acontecia qualquer coisa pesada no sítio a gente ia falar para ele. Você não sabia para onde levar, se levava na polícia, se levava no cartório. E como ele falava dava certinho, ele não mentia. Ele ajudou naquela briga de terra que o Armando já deve ter contado...O Ademício vendeu (a área do bairro)

103 SALES, R.J.R, MOREIRA, A.C.C. Reservas Extrativistas no Complexo Estuarino-Lagunar de Iguape e Cananeia - domínio Mata Atlântica. Série documentos e relatórios de pesquisa ${ }^{\circ} 22$. São Paulo: NUPAUB, 1996. p.38. 
com a ordem do João Alves. Ele deu um jeito de pegar o João Alves para dar para ele a posse. Então ele fez já no nome dele. O João era analfabeto, não sabia de nada e o Ademício fez no nome dele como se o sítio fosse dele. Ele procurou uma firma lá fora que pagou metade para ele e mandou sair todo mundo. E foi aí que o padre João entrou. Nós ficamos sem saber o que fazer, e o padre João foi ao cartório e viu que estava tudo vendido. O Padre veio e disse: eles venderam vocês todos! Ele foi lá e tentou impedir a venda, mas o cara já tinha vendido. Então foi aí que brilhou a estrela do padre João porque ele levou os registros que ele tinha feito para o Fórum. Teve uns três anos de briga e eles entraram num acordo. Eles não ganharam porque já tinham feito o registro da terra. As famílias, Ademício e todo mundo teve que entrar no acordo para cada um ficar só com um pedacinho de terra. Mas ficou também um pedaço para a firma porque ela tinha comprado e registrado. Está até hoje no nome dessa firma!

(Senhor Gentil, cunhado de Dona Dirce e morador da RDS Itapanhapima)

Não foi assim comprado. Era um senhor que era morador de lá, o senhor João Alves e sua família. Então fizeram uma proposta dizendo que iam pagar um dinheiro para ele. Tinha um pessoal interessado, que era a Sulcar. Eu acho que é esse o nome da empresa.

E o senhor João Alves não sabe ler nem escrever. Então o genro dele passou uma procuração onde ele estava concordando com aquilo, sendo que o senhor nem sabe ler e escrever.

O processo no Fórum está no nome do meu pai, Armando, meu tio Gentil, Antônio Cordeiro e Antônio de Godoi. Foram esses quatro posseiros que brigaram, junto com o padre João que é falecido. Foi ele que ganhou essa causa, senão ninguém ia conseguir. Esse cara é digno disso. E era um cara inteligente. Ele era uma pessoa que lutava pelo direito das pessoas, eu lembro perfeitamente dele, não tem como esquecer. Eu não lembro exatamente, mas faz pouco tempo que ele faleceu. Mas era um cara gente boa, viu. Um cara orientador.

O pessoal da empresa ia lá, fazia festa, os caras queimando fogos. Então meu tio uma vez encarnou, queria dar um tiro no cara. Ele chamou meu tio e falou: não faça nada, se você fizer isso, então você vai agir sozinho, porque eu não vou agir com você mais. Então escuta o que eu estou falando, faça tudo como eu disser que vai dar certo, entendeu? Não é pela violência que vamos ganhar isso aqui. Tenha calma que eu vou ganhar. Era ele e aquele advogado Dr. AntônioTeleginski.

(Adelmo, filho do senhor Armando e Dona Dirce e beneficiário da RDS Itapanhapima)

É a mesma empresa da época em que nós fomos ameaçados. Faz tempo... faz uns vinte e seis anos, porque quando aconteceu isso eu estava grávida dos gêmeos. Eu até desmaiei porque eles quebraram todas as canoas que estavam no porto. Os grileiros vieram aqui e quebraram tudo, tudo, não deixaram nada! Armando chegou aqui e disse: o que foi aquilo com as minhas canoas no porto? Ele bateu com o pé na porta nervoso, e eu falei: o que foi que está acontecendo? E ele me contou que quebraram todas as canoas, cortaram todas as minhas redes. Eu estava grávida e ele chegou do serviço de pescaria, pegou um facão e 
falou: quem eu encontrar pelo caminho eu vou matar! E eu só lembro que eu grudei na camisa dele e falei para ele: não vá! Ele saiu de lá de cima e veio para cá e eu saí grudada na camisa dele e ele me jogava pra lá e pra cá e eu grudava de novo. Eu vim com ele e encontramos com o seu Antônio Cordeiro e ele falou assim: Armando não faça isso, você tem os seus filhos para criar, a sua mulher está grávida, não faça isso. Passou três dias eu fui para o hospital, passei mal. O padre João veio, me ajudou, me apoiava muito sabe? Eu fui no médico e ele foi ver se eu estava bem, ele sempre nos apoiava. Foi uma luta, nós ficamos sem uma canoa, cortaram todas, as grandes e tudo. Depois ficou assim, eles faziam festa aqui nesse campo, traziam aquelas baterias grandonas de caminhão para fazer a festa, soltavam fogos, dançavam no campo e quando a gente fingia que estava dormindo eles vinham para queimar aqui. A gente não dormia. Depois eles cercaram tudo de arame farpado.

(Dona Dirce (D), esposa do senhor Armando (A) e moradora do Bairro Retiro que faz parte da RDS Itapanhapima)

E ainda:

Eles (padre João e as pessoas que trabalhavam com ele) ficavam com a gente, ajudavam o povo, davam força, conselho, porque o povo estava revoltado e ainda era capaz de fazer uma besteira e ir preso, pronto!

O Padre João visitava todas essas comunidades. Só aqui no Retiro moravam vinte famílias. Eu ia para a reunião paroquial duas vezes por mês e trabalhava com o padre João na catequese. Eu dava aula de catecismo para a criançada daqui. Tinha que ir duas vezes para reunião na cidade, andávamos por tudo, ia para Registro, ia apresentar os trabalhos que eu fazia e levava todo mundo comigo! Tudo de canoa.

Ia todo mundo e o padre João fazia aquela grande festa, fazia aqueles bolos e mostrava: aqui ó, aqui está o presente de vocês! Colocava na mesa e cortava! E chamava todos eles para tomar café, suco e comer bolo! Eu nunca deixei de ir para reunião! O padre João dava um livro, uma caneta pra cada um e mandava todo mundo para uma sala para desenhar.

$\boldsymbol{A}$ - Ele se esforçava e tinha que ir. Ele falava que tinha que se esforçar e ir.

$\boldsymbol{D}$ - Ele falava assim: hoje vocês vão desenhar a sua casa, o seu sítio, o seu porto, as suas canoas. Cada um ia fazer um trabalho para ir lá mostrar e depois ganhava o desenho mais bonito $e$ quem ganhava mais era a Rosilda, eles ficavam danados da vida com ela!

A-Iam todas a comunidades...do Taquari, Ariri, do Varadouro, do Marujá.

(Dona Dirce (D), esposa do senhor Armando (A) e moradora do Bairro Retiro que faz parte da RDS Itapanhapima) 
No bairro Colônia Santa Maria, cujos moradores são hoje beneficiários da RESEX Taquari, o padre João também é associado à luta contra a grilagem de terras na região. Além disso, também é atribuído a ele o papel de incentivo à formação política e educacional, respeitando as tradições locais, e promotor da união das comunidades em prol da melhora das condições de vida, independente de opções religiosas. Segundo Dona Tuca e Carlos França:

O padre João 30 que nos levou para o curso de parteira. Ele era um padre muito bom na cidade, era uma pessoa que ajudava muito. Inclusive quando vinham os grileiros de terra, ele ajudava muito.

Os fazendeiros que chegaram aí, queriam pegar o terreno dos Paulas e era um terreno muito grande. Então ele entrou em ação e os caras perderam.

(Dona Tuca, moradora do bairro Santa Maria e beneficiária da RESEX Taquari)

Eu não lembro o nome do bispo da época. O padre João era de Cananeia e abaixo dos bispos era ele. Ele tinha uma coordenação com os outros padres. É que não sou católico, e a gente não tem bem as experiências da Igreja, mas eu acho que era assim. Ele era um cara ponta firme. Ele foi um cara que ajudou muito o povo aqui. Independente de religião. A questão do grilo resolveu na justiça. A gente ganhou a causa. Na verdade, todas as causas que a gente enfrentou, a gente ganhou. $E u$, como era uma liderança que ajudei, em todas as audiências que tinha, eu levava o mapa para provar que realmente aquela pessoa tinha invadido.

(Senhor Carlos França, morador do bairro Santa Maria e beneficiário da RESEX Taquari)

No tocante à questão ambiental na cidade, o padre João dirigiu sua luta à conservação da natureza local sempre em consonância com os direitos de permanência e manutenção da cultura das populações locais. Defendeu veementemente a ideia de que a conservação do patrimônio ambiental mantinha estreita relação com a manutenção das populações tradicionais em suas áreas, o que apenas seria possível mediante a melhoria de suas condições de vida. Sua luta, nesse sentido, direciona-se contra a opressão que a legislação ambiental impunha a essas populações rurais, sobretudo as mais isoladas e pobres. Além de atuar contra a expulsão dos moradores da Ilha do Cardoso, também foi crítico e atuante contra o Parque Estadual do Jacupiranga, criado em 1969, que afetou 
grande parte da área rural continental de Cananeia, a exemplo da Colônia Santa Maria que compõe a RESEX Taquari. Assim, direcionou grande parte de seus esforços para o reconhecimento político e jurídico das populações tradicionais. Sua longa permanência na cidade permitiu que acompanhasse as mudanças ocorridas na legislação brasileira em relação às populações tradicionais e unidades de conservação ambiental. Dentre essas mudanças, destacamos o fato de que no início de 1980 é criada no Brasil uma nova categoria de unidade de conservação, a Área de Proteção Ambiental (APA) que, ao admitir a ocupação humana, representa uma primeira mudança em relação ao paradigma preservacionista que até então orientava o processo de demarcação das unidades de conservação. Diante disso, é importante retomar alguns aspectos do processo histórico que respaldou o seu surgimento.

Apesar da criação de diversas unidades de conservação, até a década de 1970 o Brasil não possuía uma estratégia nacional para a seleção e o planejamento dessas áreas. A questão da criação de áreas voltadas para a conservação ambiental começa a receber maior atenção governamental graças à pressão de agentes externos e internos ligados a uma nova consciência ambiental apresentada na Conferência de Estocolmo em $1972^{104}$. Segundo Nascimento:

O documento considerava o problema ambiental como decorrente de externalidades econômicas próprias do excesso de desenvolvimento (tecnologia agressiva e consumo excessivo), de um lado, e de sua falta (crescimento demográfico e baixo PIB per capita), de outro. Posta dessa forma, a questão ambiental deixava de ficar restrita ao meio natural e adentrava o espaço social. Graças a esse embate, o binômio desenvolvimento (economia) e meio ambiente (biologia) é substituído por uma tríade, introduzindo-se a dimensão social ${ }^{105}$.

Trata-se do primeiro evento diplomático entre Estados-Nações visando discutir a crise do meio ambiente com relevante participação de organizações não-governamentais. Na referida Conferência, criou-se uma agenda política, abrindo o "debate ideológico em torno especificamente da crise ambiental, com o processo desigual de produção e

\footnotetext{
${ }^{104}$ MORAES, Marilia Britto Rodrigues de. Área de Proteção Ambiental - APA como agência de desenvolvimento sustentável: APA Cananéia- Iguape- Peruíbe. São Paulo, 2001. p.28.

${ }^{105}$ NASCIMENTO, Elimar Pinheiro do. Trajetória da Sustentabilidade: do ambiental ao social, do social ao econômico. São Paulo: Revista de Estudos Avançados nº 26, 2012.
} 
consumo do industrialismo contemporâneo"106. Dessa forma, a Conferência apresentou a possibilidade de construção de um novo paradigma sobre meio ambiente:

Estocolmo inaugurou um marco conceitual sobre meio ambiente: das metas limitadas de proteção da natureza, conservação de recursos naturais e controle de poluição - e antecipou timidamente os elementos de uma visão mais abrangente sobre a má utilização da biosfera pelos modelos de desenvolvimento e industrialização. ${ }^{107}$

A repercussão da conferência se refletiu numa maior sistematização da política de criação de unidades de conservação ambiental que se desenvolveu no Brasil ainda no contexto de vigência do regime militar (1964-1985). Como parte dessas ações, foi criada a SEMA (Secretaria Especial do Meio Ambiente), ligada aos Ministérios do Interior e responsável pelo controle de poluição, educação ambiental e conservação de ecossistemas, e que passa a se dedicar à criação de um sistema nacional de unidades de conservação. Este órgão passou a coexistir com o IBDF (Instituto Brasileiro para o Desenvolvimento Florestal), ligado ao Ministério da Agricultura, que até então era o responsável pela proteção florestal. Em decorrência desse fato, passam a surgir disputas e divergências entre os dois órgãos governamentais, sobretudo em relação à criação do sistema nacional de unidades de conservação. Dessa forma, a SEMA, buscando combater a visão extremamente utilitarista e economicista expressa pelo IBDF, na qual as florestas são interpretadas como fontes de recursos naturais a serem administradas pelo Estado e, ao mesmo tempo, resolver o entrave representado pelos custos de indenizações que se impunham pelas desapropriações de áreas destinadas à conservação, instituiu a criação de duas novas categorias de unidades de conservação segundo os padrões da UICN (União Internacional para Conservação da Natureza): as Áreas de Proteção Ambiental e as Estações Ecológicas ${ }^{108}$. A criação das APA's constitui uma primeira ação governamental frente aos conflitos criados pelas unidades de conservação de proteção integral sobreposta aos territórios ocupados por populações rurais. Isso porque trata-se de uma legislação mais flexível, que permite a presença humana, ainda que sob uma série de restrições de uso. Além disso, apresenta as primeiras discussões em torno da construção

\footnotetext{
${ }^{106}$ NEDER, Ricardo Toledo. Crise Socioambiental, Estado e Sociedade Civil no Brasil (1982-1998) p.32.

${ }^{107}$ Idem, p.34

${ }^{108}$ MORAES, op.cit.p.29
} 
de uma gestão integrada entre órgãos públicos, organizações não-governamentais, entidades civis representativas e as populações reconhecidas como tradicionais, que vivem dentro da unidade de conservação. Como consequência desse debate e da resistência de diversas populações rurais da região, em 1984 é criada a APACIP (Área de Proteção Ambiental Cananeia- Iguape-Peruíbe), que tem como objetivo regulamentar a área em torno do Complexo Estuarino Lagunar de Iguape e Cananeia. Abrange territórios rurais e urbanos no entorno desse estuário lagunar, que compõem sucessivos ecossistemas, muitos deles protegidos por outras unidades de conservação ${ }^{109}$. A APACIP abrangeu grande parte da área continental de Cananeia, incluindo as áreas que hoje compõem as unidades de uso sustentáveis RDS Itapanhapima e RDS Taquari.

O Padre João 30 era um dos entusiastas da APACIP e participou ativamente da sua gestão como membro do Conselho Gestor da unidade de conservação. Em um texto de fevereiro de $2005^{110}$, o padre relata uma espécie de balanço dos avanços obtidos pelo trabalho juntos às populações tradicionais da região e reconhece a APACIP como uma das unidades de conservação que cumprem sua função legal, posto que "as populações tradicionais tomam conta e protegem o que é seu”. Também em entrevista concedida ao Museu da Pessoa, que realizou o projeto "S.O.S Mata Atlântica 18 anos", podemos perceber que sob a perspectiva do Padre João, esta categoria representa um avanço legislativo para as populações tradicionais:

Na APA por exemplo, se organizar as atividades, como é que vai ser feita a pesca, quais as restrições que existem para poder funcionar. $O$ comitê discute e o povo dá sempre palpite a partir de sua experiência e funciona. E aceita restrições. ${ }^{111}$

No entanto, tal percepção de avanço legislativo em relação aos seus direitos não se reflete nas narrativas dos nossos colaboradores, que sequer chegaram a citar o nome da unidade de conservação. Ainda que inseridos em uma proposta político - institucional que prevê a integração entre meio ambiente e comunidades rurais, as narrativas dos colaboradores apontam para uma ausência de diálogo, o que deixou em suas memórias apenas a marca do autoritarismo do Estado representado pela ideia de "parque" e polícia

\footnotetext{
${ }^{109}$ MORAES, op. cit. p. 56.

${ }^{110} \mathrm{http}: / /$ nomeiodopovo.blogspot.com.br/2011_03_01_archive.html Acesso fevereiro/2017.

111 http://www.bioclimatico.com.br/pdf/entrevistas/SOS_HV007_\%20PadreJoaoXXX.pdf Acesso $\operatorname{março/2017.~}$
} 
florestal, identificados como os responsáveis pela desorganização e criminalização do seu modo de vida. Para analisar tal divergência de pontos de vista e aprofundar o debate em relação aos conflitos que envolvem a criação das unidades de uso sustentáveis inseridas no Mosaico de Unidades de Conservação do Jacupiranga, apresentaremos nos próximos capítulos as narrativas dos beneficiários da RDS Itapanhapima e RESEX Taquari.

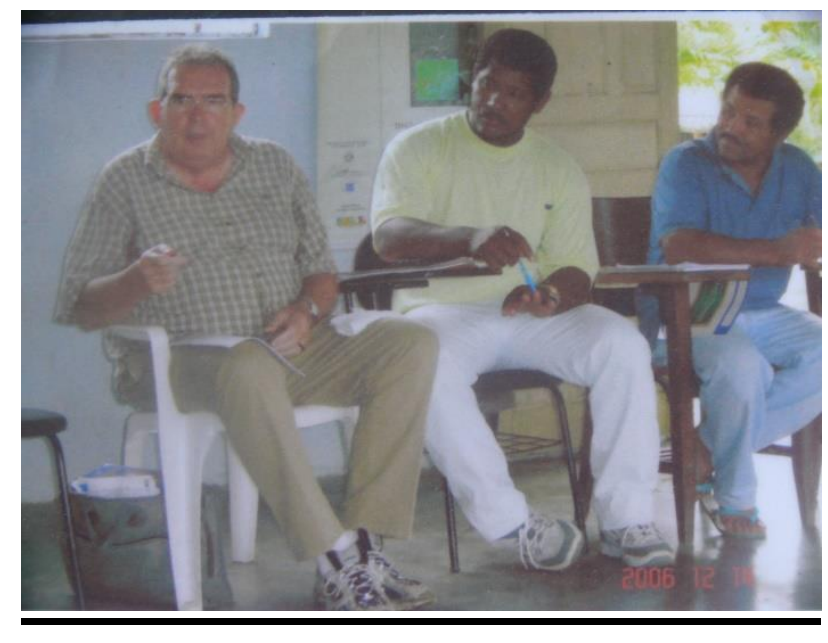

Padre João 30 no quilombo do Mandira

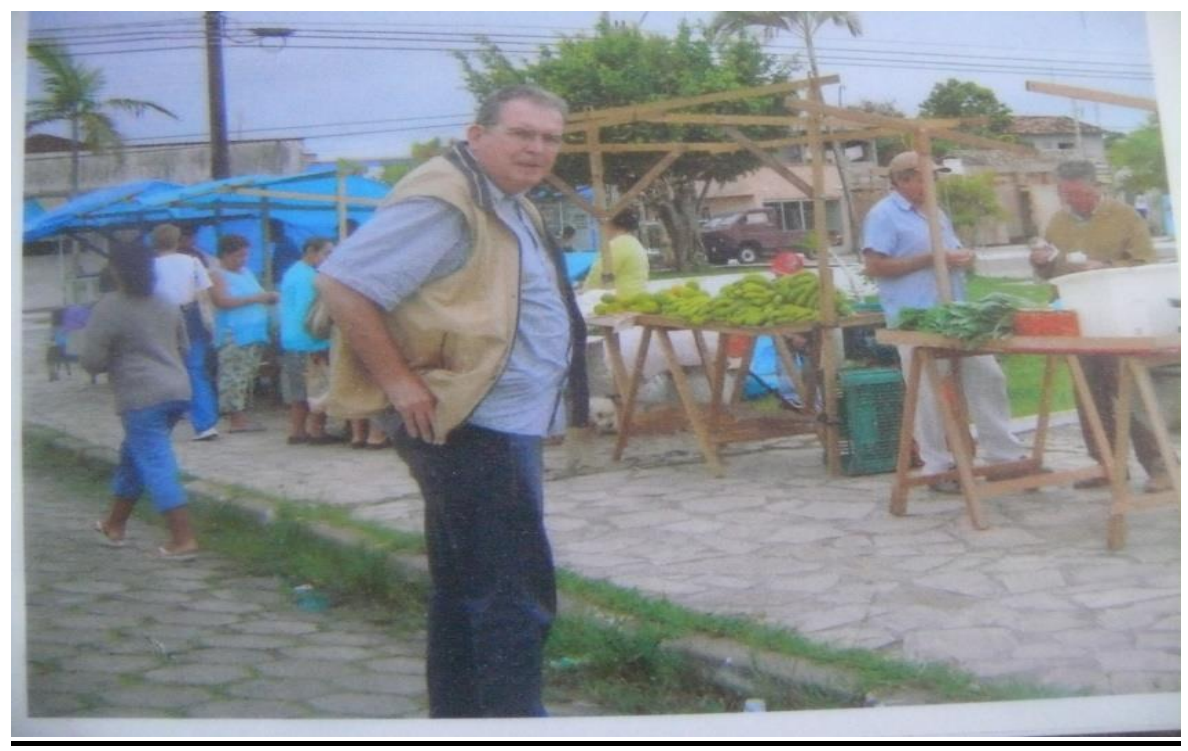

Feira da agricultura familiar em Cananéia

Fotos: Acervo pessoal de Maria Aparecida Rangel 


\section{O socioambientalismo: Uma resposta institucional aos conflitos?}

Neste capítulo analisamos as narrativas dos colaboradores reconhecidos pelo Estado como beneficiários das unidades de conservação RESEX Taquari e RDS Itapanhapima. Embora hoje eles se enquadrem nas categorias de uso sustentável criadas pelo Sistema Nacional de Unidades de Conservação em 2000 e incorporadas ao Projeto do Mosaico de Unidades de Conservação do Jacupiranga (MOJAC) em 2008, suas narrativas expressam, por meio do trabalho de memória, a perspectiva construída por esses sujeitos sociais frente às experiências vividas durante o processo de transformação de seus territórios em áreas de conservação ambiental e o reconhecimento jurídico como parte das populações tradicionais brasileiras. São histórias de vida em que o passado e o presente se reencontram, revelando críticas, percepções e interpretações dos narradores acerca da legislação ambiental na qual foram inseridos. Além disso, demonstram as múltiplas realidades abrangidas pelo conceito de populações tradicionais, categoria política e cultural utilizada como estratégia legal frente ao contexto de negação de direitos imposto a essa população.

\section{Dona Noêmia}

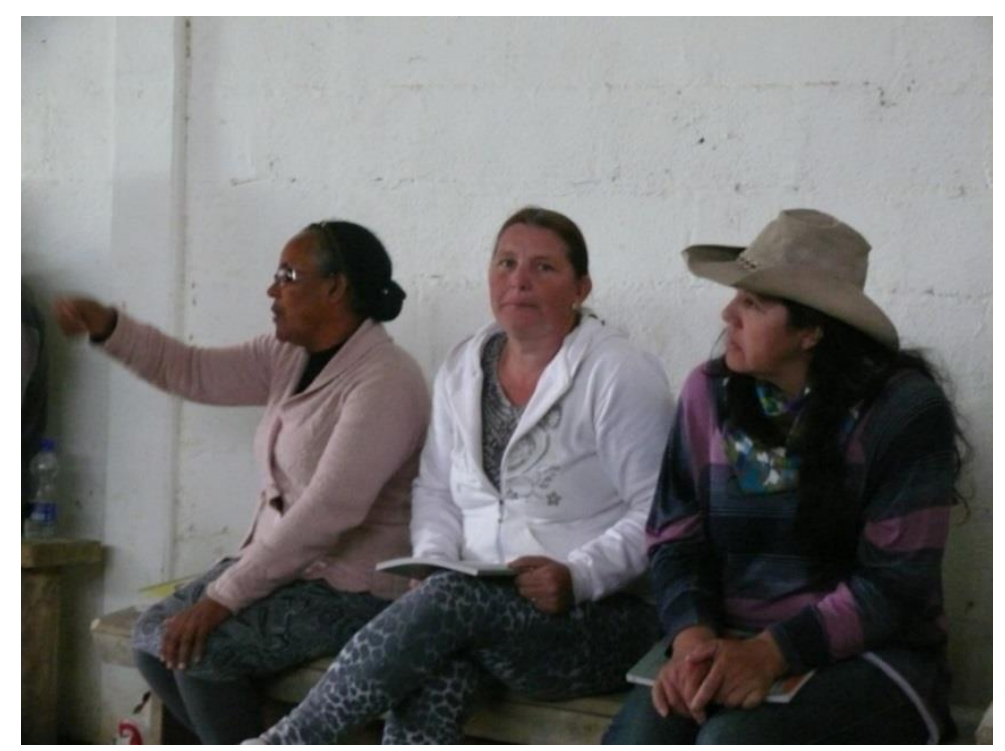

Noêmia Garcia - A primeira da esquerda para a direita.

Conheci Noêmia Garcia na reunião do conselho gestor realizada na Comunidade Santa Maria em julho de 2015. Muito atuante politicamente no início das reuniões de 
gestão, chamou-me a atenção sua fala enérgica e que demonstrava uma indignação constante. Além disso, foi uma das poucas mulheres que vi exercendo seu direito de voz nas reuniões, um espaço predominantemente masculino. Assim como muitos beneficiários da RESEX Taquari, Dona Noêmia possui moradia na cidade, no mesmo bairro em que moram muitos pescadores e moradores de unidades de conservação: $O$ Acaraú. O seu sítio localiza-se no interior da APA - CIP (Área de Proteção Ambiental Iguape-Cananéia-Peruíbe), próxima ao Parque Estadual Lagamar e da RESEX Taquari. Realizamos essa entrevista em sua casa em uma tarde de julho de 2015.

\section{“(...) ninguém melhor do que você para conhecer a sua vida, conhecer a sua casa, conhecer a sua família, a sua geração, a sua estrutura."}

Na verdade, o que percebemos é que a nossa história sempre fica para nós mesmos. Porque nunca foi publicada, de pai passa para filho, de filho passa para neto. E daí vai indo... Tem aqueles em que já está na raiz, já está no sangue aquela vontade de continuar, aquela vontade de permanecer num lugar. E outros, não. Devido ao quê? Devido a muito sacrifício, devido a muita pobreza. É um lugar tão rico, que você pode explorar tudo sem danificar a natureza. E você não pode, entendeu? Tudo tem que ser debaixo de lei, que tem ordem. Tem que procurar o IBAMA ${ }^{112}$, tem que fazer isso, tem que fazer aquilo. E até isso sair do papel para depois pôr em prática, aquele ano já se foi. Então, vem outro ano e continua tudo a mesma coisa. E você não chega a lugar nenhum. E o povo está morrendo, o povo está se acabando. A maioria da juventude está indo para cidade. E ao invés do governo colocar uma lei, ele devia dar uma oportunidade para esse povo da região mais difícil, levar alguma coisa para esse povo que ajudasse eles lá, onde estão. Por exemplo, uma escola mais ampla, do primeiro grau até o terceiro grau. Para não ter que ficar saindo de lá do sítio e vir para a cidade, deixar a sua casa lá, o seu lugar, o seu cantinho. É sitio, mas a vida dele é lá. É muito ruim ter que largar

\footnotetext{
${ }^{112}$ O IBAMA - Instituto Brasileiro do Meio Ambiente e dos Recursos Naturais Renováveis - foi criado em 22 de fevereiro de 1989 , pela Lei ${ }^{\circ} 7.735$, com a missão de executar toda a política ambiental brasileira, incluindo a gestão das unidades de conservação. Em 2007, os setores do IBAMA responsáveis pela gestão das Unidades de Conservação foram separados do órgão, dando origem ao ICMBio - Instituto Chico Mendes de Conservação da Biodiversidade, criado dia 28 de agosto de 2007, pela Lei 11.516. In: http://www.icmbio.gov.br/cairucu/quem-somos/perguntas-frequentes/20-perguntas-frequentes/73-qual-adiferenca-entre-ibama-e-icmbio.html Acesso dezembro/2016
} 
tudo e vir aqui para a cidade, que às vezes é um ambiente desagradável. É muita coisa que acontece aqui.

Então tudo isso a gente fica pensando. Porque entra um político, sai outro... É só promessa e a gente não vê nada. Quem mora na cidade até que se beneficia de alguma coisa. Mas nós que moramos no sítio, nascemos e crescemos lá, a gente vê que está indo por água abaixo. A minha vida lá, era vida de sítio. Uma vida de menina. Uma infância que a gente não tinha um brinquedo, não tinha uma boneca comprada e coisas que crianças tem vontade de ter, que deseja. A gente nunca teve brinquedo. $O$ nosso brinquedo era fazer a boneca, era brincar de casinha, pular corda, esconde-esconde, sabe? Então era uma diversão que para nós era muito boa. Eu ainda me lembro. A gente fazia amarelinha, pega-pega e coisas assim. E hoje não existe mais isso. Evoluiu bastante a ciência. O mundo evoluiu muito. Mas só que se perderam aquelas coisas que marcam a sua vida, de bom. Que é uma brincadeira sadia, é uma brincadeira saudável. Não é uma brincadeira de um machucar o outro, de um matar o outro, como a gente vê por aí. Crianças que pegam revólver e matam o outro. Então é muito diferente da realidade da nossa vida. Na minha infância, eu já trabalhava quando eu tinha a idade de 8 anos. Eu ia para a roça carregar palmito. Carregava dois, três palmitos nas costas. Não era sempre, mas quando tinha necessidade, a gente ia pegar para vender. Para comprar roupas e essas coisas assim. A gente cresceu, e o meu pai nos colocou na escola. Não tinha chinelo para pôr no pé. Muitas vezes não tinha nem pente para pentear o cabelo. Então a minha criação foi assim.

Plantava arroz, feijão, rama, milho, batata, cará, café, banana, cana... Tudo que se tem no mercado, é da roça que vem para cá, né? Mas o nosso era tudo feito por lá e consumido por lá mesmo. Arroz, feijão... o que mais se plantava toda vida era couve, salsinha, cebolinha e essas coisas assim que a gente usava de tempero. Alho, arroz, feijão, peixe, galinha de terreiro caipira, porco que se criava para de seis em seis meses pegar um para tirar a carne para comer e para fazer a banha. Você matava o porco e derretia a banha e colocava num latão. E uma lata e meia, duas daquela de banha, dava para se viver muito tempo. Era difícil comprar as coisas no sítio. E hoje, eu falo que a qualidade da vida para nós era para estar cem por cento lá no sítio. Porque tem água, tem luz, tem banheiro em casa, tem tudo. Tudo o que você tem na cidade, você tem no sítio. Só que, o que acontece: Não tem como você desfrutar, porque você precisa plantar e precisa colher. E a proibição não deixa. 
Meu sítio ficou fora do Parque ${ }^{113}$. Mas tem proibição. Tudo que for fazer lá, se for da CETESB ${ }^{114}$, você vai ter que procurar a CETESB. Se for pelo IBAMA ${ }^{115}$, você vai ter que procurar o IBAMA. E até eles analisarem e fazer esse estudo deles, o tempo vai embora. Na fundação é o Osmar ${ }^{116}$ que é mais da parte de beira mar, de ostra, da RESEX ${ }^{117}$ da água, da beira do mar. O Mario ${ }^{118}$ já é da Fundação Florestal, mas do Lagamar. Já participei em muita coisa com eles na reunião. O Mário Nunes ${ }^{119}$ mesmo, ele é filho de gente de Jacupiranga, ele já conhece o povo tudinho aqui do Vale do Ribeira, Cananéia, Iguape... Essa região todinha aqui, praticamente. É uma família daqui. Só que, por ele mesmo, por Mario, acho que não se faz nada aqui. Se depender dele, não se faz nada. Tudo que é feito no papel, a gente vai lá na reunião: olha, tem que fazer isso, escreve isso e isso. E morre por lá mesmo. Então não sei. Não adianta ter um diretor, ter zoneamento, assim como eles falam, né? Ele como diretor, conhece a vida do povo de Cananéia, do povo caiçara.

O povo caiçara, os verdadeiros caiçaras somos nós. Porque se existe isso aqui, essa mata toda aqui, é através de nós. Porque não é o governo, não é o deputado. Eles põem lei, mas eles não vem ver o que tem aqui, para gente enfrentar. E tem os grileiros, tem as pessoas que roubam a terra da pessoa, vão entrando e falam que são donos e não sei o quê. Que vai matando, que vai tirando e vai botando fogo. E que foi o que aconteceu na nossa região.

Chegou a ter muita ação de grileiros. Eu já tinha vindo para Cananeia. Já estava morando para cá na cidade, já tinha a minha casa. Mas tinha as minhas plantações, casa e tudo lá. Então o meu pai veio trazer para a cidade a minha irmã que estava muito

\footnotetext{
113 Parque é o nome genérico normalmente utilizado por muitos dos moradores para as unidades de conservação independente da categoria. Mas neste caso ela se referia ao Parque Estadual Lagamar, de proteção integral e que se sobrepôs a sítios dos moradores do bairro de Santa Maria.

${ }^{114}$ http://www.cetesb.sp.gov.br/ - Companhia Ambiental do Estado e São Paulo

115 O IBAMA - Instituto Brasileiro do Meio Ambiente e dos Recursos Naturais Renováveis - foi criado em 22 de fevereiro de 1989 , pela Lei $n^{\circ} 7.735$, com a missão de executar toda a política ambiental brasileira, incluindo a gestão das unidades de conservação. Em 2007, os setores do IBAMA responsáveis pela gestão das Unidades de Conservação foram separados do órgão, dando origem ao ICMBio - Instituto Chico Mendes de Conservação da Biodiversidade, criado dia 28 de agosto de 2007, pela Lei 11.516. In: http://www.icmbio.gov.br/cairucu/quem-somos/perguntas-frequentes/20-perguntas-frequentes/73-qual-adiferenca-entre-ibama-e-icmbio.html Acesso em março/2017.

$\frac{116}{116}$ Gestor da Fundação Florestal responsável pela Resex Taquari e Tumba e pela RDS Itapanhapima ${ }^{117}$ Reserva Extrativista

${ }^{118}$ Mário José Nunes de Souza ocupou diversos cargos na Fundação Florestal. No momento da entrevista ele era gestor do Parque Lagamar. http://www.ambiente.sp.gov.br/parque-lagamar-decananeia/informacoes-ao-usuario/ Acesso em março/2017.

${ }^{119} \mathrm{O}$ gestor o Parque Lagamar é frequentemente citado porque este parque faz parte do Mosaico de Unidades de Conservação do Jacupiranga, o qual faz fronteira ou se sobrepôs às áreas onde estão grande parte dos sítios dos moradores, dentre eles, o de Dona Noêmia.
} 
doente. Meu pai tinha doze filhos. Ele veio para cá procurar um recurso. Porque já não podia se fazer mais nada lá, era aquela perseguição. Quando o meu pai veio para cá, entrou a invasão. Os meus outros irmãos e outros tios ficaram lá. Eles vieram dizendo que eram empreiteiros e que iam para pegar gente por ali para trabalhar. E eles foram entrando, foram entrando... E a terra do meu pai mesmo, era duzentos e cinquenta e dois alqueires. E hoje é só dezessete alqueires e três hectares...

Quando eles entraram, primeiro vieram os capangas. Com certeza seriam os capangas. Tal prazo para vocês saírem, e se tal dia vocês ainda estiverem aqui, a gente vai botar fogo e não sei o quê. E foi o que aconteceu. A casa da minha tia mesmo, foi botado fogo. Foi uma coisa horrível. Então, o que aconteceu? Eles vieram e fizeram toda essa barbaridade, expulsaram a maioria do povo das terras. E o que eles fizeram depois? Desmataram tudo. Deixaram que nem esse piso aqui, ó. Isso há vinte, trinta anos atrás. Há vinte e poucos anos. Foi em oitenta e seis, oitenta e oito.

E depois o que aconteceu? Aquele moço que estava lá ontem, o Carlinhos $^{120}$, eu tiro o теи chapéu para ele, porque foi graças a ele, e primeiramente a Deus que deu para ele a luz, a força, a vontade, a garra de enfrentar esse povo. Como é que você vai deixar uma pessoa entrar na sua casa? E depois você não vai poder entrar mais. A pessoa vai dizer que é dono. Então o que aconteceu foi que ele correu atrás, e acionou o prefeito daqui que na época era o seu Maurício. O seu Maurício acionou a polícia, e vieram com aquela soldadera, aquele monte de gentarada. E vieram mesmo para pegar. Os capangas, quando viram aquela barbaridade, meteram a cabeça no mato. Tem gente que até hoje não voltou mais lá. Deixou a terra abandonada. Era gente de longe. De lá, que eu saiba assim, não tinha ninguém. Isso foi no ano de oitenta e seis, mais ou menos. Oitenta, oitenta e seis, por aí.

Foi o Carlinhos que enfrentou tudo lá, a bocada. Os caras iam discutir com ele, e ele não tinha medo de discutir. Eu sei que foi indo, foi indo, eles foram tudo para a justiça. E sei que eles abaixaram a guarda e foram saindo, sabe. O único que permaneceu lá, mas que hoje não está mais lá, é o João Lisboa Guimarães. Ele entrou na terra do meu pai. Ele foi no cartório, fez um levantamento, pegou todo os nomes da família e ninguém sabia assinar nada. E quando o meu pai viu, ele já tinha tomado conta do terreno do meu pai todo. Então ficou assim. Com documento e tudo. E ele era advogado.

\footnotetext{
${ }^{120}$ Carlos França, morador do bairro Santa Maria e também colaborador desta pesquisa.
} 
Além dele ser o grileiro, ele e a mulher dele eram advogados, entendeu? Então foi muito difícil.

E hoje tem poucas pessoas que estão lá... Como o meu tio. O meu tio está lá ainda, e tudo... mas ele puxa muito para o lado de terceiros mesmo, de pessoas que ele não conhece. E você tem que saber com quem você conversa, com quem você anda porque você não sabe. Se você está conversando com uma pessoa, bem dizer você está dando o seu pão para ele. E, às vezes, essa pessoa não é nada daquilo que você está imaginando. E ele está lá agora, praticamente sozinho... quer dizer, está ele, os filhos e a família. Eu tenho a minha casa lá, a minha irmã tem a casa dela lá. Mas é assim, a gente sempre fica com um pé na frente e outro atrás. Porque, querendo ou não, sempre tem alguém por trás disso. O grande não vai, mas ele manda. O encomendador né, que é como se diz na história.

Mas lá é um lugar muito bom sabe, eu sinto muita saudade. Eu tenho vontade de ir para lá e viver o resto da minha vida. Terminar o resto da minha vida no sítio. Lá, você tem paz de espírito, você dorme sossegado, tudo que você faz lá é sossegado. É uma terapia para sua cabeça, para sua mente. Você não tem tempo de ficar pensando no que não presta. Coisas desagradáveis... E é muito bom. Mas a gente praticamente não tem apoio. A gente faz parte da gestão, vai na reunião, ajuda eles e tudo. E eu acho que eles também deviam colaborar. Fazer um plano de manejo o mais rápido possível. Porque as pessoas precisam daquilo ali. Se não tiver um plano de manejo completo para as pessoas trabalharem e viver a vida do sítio, o povo vai acabar vindo para a cidade. E fazer o quê na cidade? Não tem emprego, não tem estudo, não tem uma profissão. Uma pessoa com 48 anos, 50 anos, não pega mais emprego numa firma, ninguém dá porque já passou da idade. Então está se tornando tudo muito difícil para as pessoas que moram ali na região.

O negócio do parque, na verdade, eu nem sabia quando tinha começado isso. Eu sei que umas épocas foram lá no sítio fazer uma pesquisa e tudo mais, aí minha cunhada que hoje já é morta e o meu pai disseram assim: esse negócio de pesquisa e esse povo de fora vindo de lá para cá, é alguma coisa que o governo está inventando. E dito e feito. Foi o que aconteceu. Eles já tinham feito os estudos deles, eu acho que via aérea e tudo mais. Eles fazem o estudo deles e quando estão com o estudo tudo feito e planejado, daí eles convocam o povo e diz que fizeram isso e aquilo assim, assim e assim. A pesquisa era para ver quantas famílias, quantos moradores tinham, e aquela coisa toda, mas não falaram para que era. Ah, isso foi no ano de sessenta e um. Foi bem antes. Eu nasci em cinquenta e oito. Bem antes de eu ter nascido, já tinha essa coisa de pesquisa. Eu lembro 
que meu pai falava. A gente era tudo pequenininho e o meu pai falava que andava uns homens por lá, umas pessoas fazendo perguntas. Depois foram embora e nunca mais apareceram. Aquele povo nunca mais apareceu.

Depois passados muitos anos, veio aquele levantamento que faz de ano em ano, esse tal de censo. Depois que eu fui saber que era isso, e que antigamente eles já estavam fazendo isso. Mas ninguém falava para que era. Então eu acho, quer dizer eu tenho a plena certeza que, quando existia muita gente no sítio, eu acho que o governo, se ele fosse lutar, ele não teria força. Hoje, já não tem mais ninguém. Então cada dia ele vai avançando mais. Porque não tem ninguém para brigar pelos seus direitos. São poucas pessoas que tem meios para brigar, para defender seus direitos. Então, o governo está deitando e rolando, entendeu?

Com tudo isso, foi ficando difícil. Antes as pessoas trabalhavam e cuidavam da vida. Até os meus 15, 16, 17 anos... até uns 20 anos, as coisas eram bem mais tranquilas. Depois, de uns tempos para cá que o IBAMA caiu mesmo matando em cima do povo. Então o povo fazia denúncias deles, que vinham pessoas de fora para se beneficiar e tirar as coisas dali. E a cada denúncia foi abrindo a ideia do parque mesmo. Eforam tomando conta de tudo. As pessoas que trabalhavam na Ilha do Cardoso, os moradores que cultivaram aquilo lá, que cuidaram... Hoje, até as casas deles foram tiradas de lá. Então, eu acho isso errado. Eu acho muito errado, sabe por quê? Veja bem. Poxa, ninguém melhor do que você para conhecer a sua vida, conhecer a sua casa, conhecer a sua família, a sua geração, a sua estrutura.

O povo nasceu ali, se criou ali, vivia ali, do peixe. A maioria vinha do peixe. Fazia roça sim. Não era esse mundo de roça que a gente vê hoje nessas cidades como Campinas, Sorocaba, esses lugares que a gente viaja por aí e que tem hectares e mais hectares e você não vê um pé de árvore. É uma campina. Isso eu acho que é um crime. É um crime ambiental. Então é muito difícil você engolir certas coisas. As pessoas que nasceram ali na sua terra, que cuidaram daquilo com amor e com respeito porque faz parte da vida da gente. Às vezes você é tirado à força. E o governo não fala para você: o quanto você quer? Ele não faz nada disso. Se quer que saia, se quer que desocupe, pague. E mesmo assim ainda é ruim. Mas pelo menos a pessoa sai de lá com um bom dinheiro, vem para cidade, investe em alguma coisa. Não está no sítio, mas pelo menos ele tem uma casa digna para morar embaixo dela. Mas como o governo faz é sair sem casa, sem dinheiro, sem trabalho, sem garantia de nada. E o governo não sabe que ele está fazendo um grande mal? Pois ele está fazendo um grande mal. Eles acham que estão fazendo o 
bem, mas eles não estão fazendo o bem para humanidade. Não está. E um dia isso vai ser cobrado. Pode ter certeza. Um dia vai ser cobrado.

Antes tudo era mais tranquilo. Já trabalhava na roça. O meu marido era lá do Paraná. Eu o conheci por sorte do destino. Uma vez eu conversava com ele e eu falei: Nossa Ge - eu chamava ele de Ge, porque era Gentil, e eu chamava ele de Ge e ele me chamava de preta - e eu falava: Ge, se nós fossemos fazer a nossa história, dava um livro. Nós nos conhecemos ele morava no Paraná. A mãe dele era daqui e o pai era lá do Paraná. Ele veio para cá, menino ainda, moleque. Ele veio morar com o irmão dele. $O$ irmão dele acolheu ele e falou: olha, você vai morar comigo, mas vai ser assim e assim. Primeiro ele morou lá no Carapara e depois eles vieram morar no sítio do meu pai, o irmão dele com ele. Ele era conhecido da família. O meu tio que é irmão do meu pai, deu lugar para o meu cunhado, irmão dele. O meu cunhado foi para lá e morou muitos anos. Saiu para vir embora para Cananeia, por conta dessa bagunça toda que teve no sítio. Ele começou a trabalhar com o monte, que era como se falava antigamente. Era tudo com o monte. Tudo o que se fazia era ali. Podia ter dois, três ou dez irmãos, que trabalhavam tudo para o monte com o pai. E o meu pai no final de ano, vendia, fazia as contas lá, fazia o balanço das despesas e do que sobrava. Então dividia e dava uma parte para cada um. E dinheiro para moço, ele comprava sabonete, naquela época era aquela brilhantina que passava no cabelo e ficava tão cheiroso... Era muito cheiroso. Era um perfume que se você estava aqui, sentia lá pela avenida afora... você já sentia o cheiro, de tão gostoso que era. Então porque ele trabalhava com meu pai, conheci ele... E quando eu o vi, eu me apaixonei. De cara, assim. Eu era menina nova ainda, criança, sabe? E ele também. E então eu fui crescendo para cá e ele para lá... a gente foi crescendo. Depois resolvi e fui embora para Santos. E na época que eu fui embora, ele também veio embora para a cidade.

Eu fui para Santos tinha 14 anos. Fui para lá trabalhar, tomar conta de criança. Fiquei um pouco e depois a minha irmã faleceu, e vim para cá, já para ficar. E começamos a namorar. Eu ia fazer 16 anos. Comecei a namorar com ele. A gente morava tudo no sítio. Depois a gente foi morar junto. Nós não tínhamos nada. O que ele tinha em favor dele eram dois pratos, duas colheres, uma panela e uma coberta. A gente foi morar, como a gente fala, na capuava. Era a capuava do meu pai. Capuava é assim: Aqui é a beira da estrada... é aqui onde você mora. E você tem um sítio onde se faz a plantação, bem longe de casa, então se chama capuava. Tem o rancho lá, você vai e fica a semana toda e só vem no final de semana para fora. Para fora que a gente fala, é o para o meio 
do povoado. Então, isso chama-se Capuava. Ficamos morando lá bastante tempo. Então ele ficou doente. Teve uma dor de dente muito forte. A gente já tinha plantado duas roças de rama, de mandioca, tinha bastante coisa. Ele não podia trabalhar. E tinha que tirar palmito, tinha que ir muito longe para buscar palmito. E ele falou: olha, nós vamos ter que sair daqui, porque está ficando muito difícil para mim trabalhar aqui. Nós vamos para beira mar, mais para perto da água. Eu falei: tudo bem, e onde vamos ficar? Ah, vou alugar uma casa do Oscar Klimke, que era um fazendeiro que tinha lá e tinha bastante casa perto da beira mar. Ele arrumou para ele e falou: para você, eu não cobro nada. Vá trabalhar e vá cuidar da sua vida

Começamos a trabalhar. Trabalhamos na pesca. Tirava ostra, limpava a ostra, e vendia. E foi indo. E quando já estava tudo bem organizado, nós viemos trabalhar numa fazenda chamada Fosfaza. Só morava na casa do Klimke porque ele era conhecido do meu marido. A família dele morou lá por muito tempo, muitos anos. E cuidava de tudo para eles. E lá era assim, quando você prestava um favor para pessoa, quando você precisava dele, ele não cobrava. Ele dava para você usar o tempo que você quisesse. Era muito boa a nossa vida. Um costume. Tinha que ser assim, e tinha que continuar assim.

Porque antigamente era assim: O meu pai era um homem muito caridoso e muito bom e ele era muito procurado para tudo. Então quando chegava tempo de roça, era assim: olha, vamos fazer um mutirão? Vamos fazer um ajutório. Então juntava aquele monte de gente, aquele mundo de homens para roçar. Era que nem fazer uma roça de um dia, de um alqueire de planta. Fazia uma conta assim: um alqueire era um saco de arroz, dois alqueires, dois sacos... Juntava praticamente umas vinte, vinte e cinco pessoas, entre homem casado e rapaziada. Um pouco ia na frente roçando, e um pouco ia atrás derrubando e já desgalhando. Desgalhando é cortar tudo os galhos e deixar tudo baixinho, sabe? Aí no dia fazia uma roça. Isso aí, a gente chamava de mutirão. E a noite tinha o baile, o fandango ${ }^{121}$, tinha todas essas coisas.

Era assim e na outra semana já ia trabalhar para outro. Então todo mundo tinha. Vê que ninguém metia a mão no bolso para pagar a mão-de-obra. Todo mundo ajudava o outro. Tinha a comida, tinha o café e tinha tudo. Era tudo por conta do dono da casa. E era muito bom. E a gente conversa hoje que faz falta aquilo. Hoje você procura uma pessoa e mesmo você pagando, ninguém quer trabalhar. O fandango era bom. Tinha o bate pé, que eles falavam. Tinha marrita, manjericão... Tinha um monte de coisa, as

${ }^{121}$ Fandango é uma manifestação popular que reúne dança e música e que ocorre em localidades diversas do Brasil. Dentre esses locais temos parte do litoral Sul de São Paulo e litoral norte do Paraná. 
linguagens deles, as danças.... Tinham várias. Tinha batido. Batido ainda tem até hoje. Tinha a dança do recortado, também. Eu era criança, mas eu lembro. Vixe! Era muito bom. O povo se divertia à beça, sabe. E acabou tudo. Está acabando a raiz. É uma pena.

Está acabando porque a juventude já não quer mais. Eu acho que por causa de tanta coisa que acontece, eles já não acreditam mais em nada. Eles vêm para cidade, sofrem, estudam. Alguns conseguem ser alguma coisa na vida, outros não. Mas já perdeu a esperança de viver no sítio com tudo aquilo que podia ser revisto novamente. Quando eu era jovem o meu sonho era ser médica. Mas infelizmente naquela época, moça não estudava. Estudava até a quarta série. Aí ficou mocinha e começou a criar peitinho e tudo, o pai já tirava da escola. E ficava em casa. Antigamente era assim. Era a criação. Hoje, não. Hoje você é livre. E não foi só o meu pai. Eram várias pessoas que vinham de uma tradição assim. O meu pai era neto de escravo. Eu sou bisneta de escravo. Ele contava. Ele conheceu a mãe dele e a avó dele. A mamãe dele veio da África, quando tinha 11 anos de idade, com os amigos dela e tudo. Ela não foi muito judiada. Mas quem veio com ela de lá para cá, foi muito judiado. Eu não sei como eles vieram para Cananeia, se foram descarregados aqui. Porque aqui antigamente tinha um porto, que é onde eles negociavam os escravos. Mas, normalmente, eu acho que vinha para Santos, descarregava lá para depois vir para cá.

Aqui se plantava muito arroz. Arroz, café... Tem um amigo meu, que a avó dele, a mãe do pai dele foi trocada por um saco de café. Agora, você imagina que situação?! É um absurdo, né? Eu não entendo. Eu gosto muito de observar as coisas. Eu não sou muito de falar, não. Eu sou mais de ouvir. Porque, veja bem: você analisando bem, está quase a mesma coisa. Eu falo para as pessoas. Está quase a mesma coisa. Porque hoje, para escravo, não falta nada. Você concorda comigo? Ah, estamos em liberdade.... Estamos em liberdade nada. Isso não é liberdade. O governo vem e tira o que você tem? Foi assim que começou. Quando os franceses e os portugueses vieram, eles invadiram a nossa terra. Os índios já viviam aqui. Você estuda, e você sabe. Está tudo a mesma coisa. E antigamente eles não tinham um documento para mostrar que era dele, mas eram deles. Porque, quando eles chegaram, os índios já estavam ali. E hoje você tem seu documento e tem a sua propriedade, e é expulsa mesmo assim. Está acontecendo a mesma coisa.

Agora, quando virou Resex ${ }^{122}$, eles não pediram nada, nenhum documento porque o parque já tinha pego praticamente tudo. Ficou só a área dos manguezais e essas coisas.

\footnotetext{
${ }^{122}$ Reserva Extrativista Taquari
} 
Eu não perdi terra para o parque Lagamar. Mas a minha amiga que mora lá, perdeu. A Rita Zafanero. Ficou quase tudo dentro do parque. O Carlinhos também. Era do pai dele, quando ele veio da França com os avós. Ficou tudo dentro do parque. A cunhada dele, e o tio dele, ainda tem casa, tem fazenda, tem tudo lá. E moram lá. Mas só que eles não podem trabalhar porque são perseguidos ali. Então, eles vão trabalhar lá para o lado do Paraná. Mesmo meu sítio não estando dentro do parque, ainda assim tem problema ${ }^{123}$. Você não pode tirar madeira, você não pode tirar uma lenha para vender. Para você tirar bastante lenha, você tem que ter um documento, tem que ter uma autorização.

O uso você pode fazer, que é tirar lenha para queimar. Agora, para vender não pode. Madeira não pode também. E quando você vai fazer um benefício dentro da sua propriedade, você tem que ir no IBAMA, conversar com eles para pedir autorização para a madeira, e eles tem que mandar um documento para você. E esse documento vai lá para a CETESB, que faz o estudo deles lá. Então aprova, e você vai trabalhar. Eu já fiz para tirar madeira. Eu fui lá. Conversei com o Osmar, e falei que precisava de madeira para fazer cerca. Era madeira branca, porque madeira de lei não tem mais. Madeira de lei hoje, se tivesse você iria usar só para fazer os pés de casa. As madeiras brancas são jacatirão, guanandi, tabocuva, jacatauva, canelinha e esse tipo de madeira, né? Para fazer palanque assim, de cerca, o que mais usa é o jacatirão. E eu consegui a autorização lá no meu sítio, sabe. E não demorou muito. Porque como eu já fazia parte do conselho ${ }^{124}$ e tudo, então para mim foi fácil. E assim a gente também tem que ter um pouco de paciência. Se a lei está aí, ela tem que ser cumprida. Se tem que ser cumprida para o pequeno, tem que ser cumprida para o grande também.

Porque, geralmente, o que tenho visto acontecer aqui em Cananeia, é o seguinte: tem a parada do defeso ${ }^{125}$, do camarão sete barbas e outros peixes. Poxa, respeitem. $O$ pequeno não vai pescar, e o grande pesca, entendeu? Enquanto o pequeno está respeitando aquela regra, o grande está lá fora pescando. Então, eu acho que isso é errado. A portaria da lei tem que ver isso. Para isso existe a portaria. E a fiscalização aqui não funciona. Funciona mais para os pequenos. É o pequeno que às vezes sai e

\footnotetext{
${ }^{123}$ O sítio de Dona Noêmia está no entorno do Parque Lagamar. Tratar-se, portanto, de uma área de amortecimento, sujeita também à legislação que regula o uso segundo o SNUC (Sistema Nacional de Unidades de Conservação da Natureza):

XVIII - zona de amortecimento: o entorno de uma unidade de conservação, onde as atividades humanas estão sujeitas a normas e restrições específicas, com o propósito de minimizar os impactos negativos sobre a unidade. In: http://www.planalto.gov.br/ccivil_03/leis/L9985.htm Acesso em janeiro/2017.

${ }^{124}$ Conselho gestor da unidade de conservação.

${ }^{125}$ Períodos do ano em que a pesca de determinadas espécies é proibida.
} 
precisa comprar um remédio porque está com a família doente. É o que tem um salário pequeno. O pescador é isso. O salário é o que ele tira para sobreviver. Ele vive daquilo ali. E se ele não tirar aquilo ali, ele vai morrer de fome. O governo não paga salário o mesmo para ele. Se o governo colocasse ele na reserva e desse um salário decente, eu garanto que as coisas iam ser bem diferentes. Mas o pequeno não tem do que sobreviver enquanto não pesca. E enquanto a portaria está aberta, ele está comendo, bebendo, pagando as contas, as dívidas e suprindo as necessidades dele. E aí, quando fecha a portaria para a pesca, ele vai viver do quê?? Me fale. Três meses de auxílio. São setecentos e pouco. E dá dois mil e pouco. E ele gasta muito mais do que isso. Eu mesmo não fazia nada, respeitava.

Eu e meu marido íamos para lida. Pescava com gerival para camarão... Gerival é uma vara bem grande. Você coloca a tarrafa ${ }^{126}$, e ela faz tipo uma carapuça, que era como um saquinho que você colocava ali. A carapuça ficava aberta, e no meio tinha um arame. Então a boquinha fica um pouco aberta e se for na água, ela abre. Aí você solta a tarrafa, e a gente vem puxando com a canoa ou no motor. Ela abre. E conforme ela abre, o camarão vai batendo lá embaixo e vai subindo. Então vai caindo ali dentro da carapuça. É muito legal e muito gostoso. Tudo quanto é tipo de peixe vinha na rede. A gente alternava. Eram seis meses na água, seis meses na roça. O meu pai ensinou a gente assim: seis meses de água. E quando encerrava a pesca, era o tempo de cria dos peixes. O meu pai já sabia de tudo. Então, nós aprendemos. Hoje, a maioria está sendo obrigado a desafiar a natureza por essa razão. Porque o defeso está errado. Eu acho que o governo devia pagar mais. Ou dar uma cesta básica, alguma coisa. Porque são seis meses. E o governo só paga três meses. Mas o certo é seis meses que tem que ficar. É que nem a caça. A caça no mês de janeiro, fevereiro, março, abril e maio. De setembro em diante, você já não faz mais nada. E de abril em diante, já está grande. O que nasceu, já está com seis meses, sete meses. Então de maio em diante já pode caçar até setembro.

É a tradição da gente, entendeu? A gente respeitava a lei da natureza. E hoje, os pequenos respeitam. Mas só que os grandes não. E hoje, por certas regras, os pequenos acabam tendo que ir para o mar pegar alguma coisa para poder comprar o que levar para casa. Se não, eles vão morrendo de fome. De algum jeito ele vai ter que levar o sustento pra casa. E por infelicidade, por azar, ele acaba caindo na própria armadilha que ele mesmo armou. Porque sai para procurar comida, e vai parar na cadeia para

${ }^{126}$ Uma tarrafa é uma rede de pesca circular com pequenos pesos distribuídos em torno de toda a circunferência da malha. 
pagar algum processo. Esses tempos atrás, acho que vai fazer dois anos que pegaram o filho do seu Armando ${ }^{127}$, que também fazia parte do Conselho. Prenderam o filho dele. Eu não sei qual dos filhos. Eu sei que ele estava trabalhando dentro da reserva. O que eu acho é que o povo cuidou a vida inteira e aquilo ali é o coração dele. Ele sabe como trabalhar. Se vai matar uma caça, ele não vai vender, ele vai levar para casa, para comer. Nós que estamos na cidade, nós vamos ao mercado e compramos frango, compramos bife e levamos na hora para casa, para os nossos filhos comerem. E quem mora no sítio? Como é que faz? É muito difícil.

A caça era bem comum. É que nem o Mario falou para mim, na primeira reunião que teve do parque onde tinha muita gente e ele falou: o povo tradicional pode pegar um ou dois para comer. Eles têm liberdade. Agora, para vender, não. Se a gente pegar mais de dois, não pode. E era assim mesmo antes, pegava um ou dois e comia. Acabou em quinze, vinte dias, então ia para o mato de novo. E não era para vender. Hoje, nós caiçaras, nós não podemos matar para comer. Mas tem gente que vai da cidade para o sítio em época de matar as caças, e mata três, quatro ou cinco na noite. E enchem o freezer para vender. Então, isso tinha que acabar. Porque ele é bem empregado, ele pode ir no mercado e comprar um quilo de bife para comer, ele pode comprar outra coisa para comer. E para que ir lá tirar o sustento das pessoas? É claro que eles vão vender, se eles estão precisando. Então o governo tinha que rever isso. Porque não há necessidade de ser assim.

Olhe bem, antigamente a gente trabalhava na roça, e tinha café, açúcar, milho, galinha, ovos de montão, banha de porco na lata... Tinha o leite da vaca. E o que a gente ia comprar, se tinha de tudo? A única coisa que a gente comprava era o sabão, querosene, roupa e coberta. E o palmito que era tirado antigamente, era para isso. Não era para fazer exportação, entendeu? Era para sobrevivência do povo. Hoje, você não acha mais palmito porque proibiram muitas coisas para fazer. Porque, é o que eu falo para vocês: mesmo tendo a reserva, tinha que ter a liberdade para o povo trabalhar.

A liberdade é assim: não desfazendo da nossa regra, do ensino que nós aprendemos. Roçar como sempre, plantar como sempre. Vê uma quarta de terra, vai plantar. Planta três, quatro quilos de feijão. Roça aquele outro pedaço se precisar... Mas não pode. Não pode. Para você fazer roça, você tem que ter licença ambiental. Se você não tem licença ambiental, você é preso e multado.

${ }^{127}$ Beneficiário da RDS (Reserva de Desenvolvimento Sustentável) Itapanhapima e também colaborador deste trabalho. 
Então a reserva na verdade não funciona. Porque você querendo o bem ou não, você continua sendo aliada deles. Mas eles não são seus aliados. Porque você continua morando lá em cima das terras, e você não pode fazer nada. Você limpa, você trata, você cuida, mas você não pode cortar uma madeira e não pode fazer nada. E o que eles estão fazendo para essas pessoas que estão lá? O Plano de uso, na verdade, parecia bom. Mas só que ficou no papel. Eu acho que no plano de uso, o que já estava sendo feito como a extração da ostra, mexilhão e essas coisas, já não tinha necessidade de entrar. A ostra, por exemplo, teve que entrar. Mas é uma coisa mais rápida, que o pessoal tirava mais, $e$ não demorava muito para conseguir autorização. Só que, o que demora mais, não saiu até hoje que é, por exemplo, o corte de madeira, extração de madeira... Não saiu. Praticamente, a maioria do povo que está vivendo aqui, as pessoas estão fazendo viveiro de ostra, né? É o que sobrou dentro da reserva, para os que ficaram... é que nem aquele povo ali de Santa Maria. Aquele povo morava tudo dentro da reserva. O povo tudo ali, daquela comunidade.

A minha casa fica ali na subida perto da escolinha. Então, a minha casa é para cá um pouco, antes de atravessar para o Santa Maria. Mas lá a maioria do povo vivia dentro do parque. Eles mudaram para cá porque não tinha luz. Era uma dificuldade para colocar luz dentro do parque. E essas coisas todas. Nós fizemos uma reunião e, na época participaram mais de duas mil pessoas, quando começou todo esse alvoroço. Eu acho que foi no ano de 2006, 2005. Muita gente. Todo mundo ia. Eu ia com a intenção de que o parque ia trazer benefícios, que o parque ia ajudar e que ia melhorar. E no fim... Aconteceu que o povo ficou encabulado achando que ia voltar a trabalhar, roçar $e$ plantar. E ninguém podia roçar, ninguém podia plantar e não podia queimar. Porque o nosso uso é caiçara é a roça e o fogo. E a gente não podia queimar. E toda vida nós queimamos. Era assim, a gente fazia roça, e o meu pai falava assim: esse ano quero fazer uma plantação boa. E ele ia lá no meio do mato grosso e fazia uma coivara. ${ }^{128}$ Depois roçava. No ponto de queimar, ele ia lá e roçava numa largura mais ou menos dessa aqui. Tirava todos aqueles matos secos, cipós e essas coisas que pudessem passar fogo. Então você podia queimar sossegado. Toda vida foi assim. Nunca um fogo passou para outro mato. Nunca. Você podia plantar, podia dar vento não fazia devastação nenhuma ... Hoje, olha esse mundo de fogo que pega por aí. Essas campinas que vão embora e que acaba com tudo. Mas o nosso não espalhava por causa do controle. E a gente tinha esse

\footnotetext{
${ }^{128}$ Método tradicional de queima controlada para a preparação do terreno para cultivo.
} 
controle. Assim, por exemplo, aqui é a roça. Aqui é a beira da roça. Aqui é a mata virgem, o mato serrado. E daqui para cá nasce a roça. E termina aqui também, em outra mata virgem. A roça fica no meio. E aí, o que acontece? Antes do meu pai queimar a roça, ele ia e limpava tudo como se tivesse limpado com enxada. Como se fosse uma canaleta. Não passava nem fogo para lá, e nem fogo para cá. E podia queimar sossegado. Todo mundo fazia isso no sítio. E hoje não pode fazer mais e não tem como trabalhar. Não esgotava a terra. Era assim: você queimava. E no máximo em três dias, no outro dia depois da queima, o meu pai já pegava a semente e já ia para roça plantar. Então ele aproveitava toda aquela cinza. E então o que acontecia? Vinha à colheita, e o meu pai colhia e levava para casa. E naquele lugar ali, você não plantava mais, até crescer o a mato por igual. Era assim a nossa vida. Se nesse ano ele fez nessa parte, no outro ano ele ia fazer lá distante. E assim era. A nossa terra sempre foi cultivada assim. Nunca precisou de adubo, agrotóxico... Todo mundo tinha, e com fartura. E de tanto que tinha, muita coisa de estragava. De tanta coisa que se produzia, entendeu? Era assim.

Remédio era muito difícil. Era da natureza. A gente fazia o lombrigueiro de erva de Santa Maria. Hortelã... A gente dava para eles tomarem. Se as crianças começassem a crescer a barriga, é porque andava de pé no chão, tinha um monte de verme. E então fazíamos os remédios lá. Era uns remédios ruim de tomar! Tem uns remédios que é bom, que é docinho. Mas esses eram amargos, mesmo. Alguns eu ainda uso como a quina. A quina é uma árvore que dá no mato, que a gente tira a casca dela. Ela serve para muita coisa. Cura qualquer tipo de mazela. Mazela é no linguajar que a gente fala. Mas é tudo quanto é tipo de mazela. É infecção, constipação... E serve para curativo. É para bexiga, rim, estômago e tudo, sabe. Tem o milome. O milome também é muito bom. $\quad$ É para tudo quanto é tipo de coisa, também. O milome é um cipó. E a quina é uma árvore. Os dois são bom pra tudo... Quem quiser optar por quina toma quina. E quem quiser tomar o milome, toma o milome. Os dois são amargos. É amargo que Deus me livre. Ah, tinha um monte. Tinha rubarbo, abuto, rosa branca... Tinha um monte de remediada. Tem tudo no sítio. É só procurar lá, que acha. No mato, a gente imagina o que se pode ser extraído de lá. Hoje o povo não tem necessidade de sair de lá. Porque a ciência está muito evoluída. E se for para montar um micro, pequeno laboratório de pesquisa, se for uma moça ou um jovem de lá mesmo com estudo, pode capacitar e montar ali, sabe. Montar alguma coisa dentro do núcleo ali, sabe? Para estar passando aquela experiência para outras pessoas. Porque, a gente já conhece. E com o estudo da teoria e na prática, os dois vão muito bem. Agora, se tem a teoria e não tem a prática, já é meio difícil. Por um 
lado você conhece, que é na teoria. Mas na prática, você não sabe o que é. Então, teoria e prática funcionam muito bem. Porque lá em Santa Maria, já tem o galpão, tem a cozinha e tudo. Deveria montar um tipo de um negócio para desenvolver remédios, sabonetes, cremes. Extrair dali. Porque tem muita coisa que pode se extrair dali do sítio. Para a pessoa estar fazendo para a gente mesmo. Ah, eu acho que deveria ter, né? Olha, no começo quando era o Marcelo e a Daniela fazia parte, que eu fazia parte também. $O$ Marcelo trabalhava na "Gaia"129, aqui... Conheci ele através dos musgos com que trabalhei como veludo, fofão... E a gente começou a trabalhar juntos. E ele se interessou pela minha região, que era Taquari e Santa Maria. A gente começou a trabalhar juntos e foi onde foi ajuntando para a volta do mutirão. E desse grupo que foi formado em 2005 , 2006, está o Clodoaldo que é daqui do Rio Branco, o Ibison lá do porto do meio e o Reinaldo. São três. E tem mais um no Rio Branco. E lá do Santa Maria não foi ninguém. No Santa Maria não foi para a frente por causa da estrada. A estrada era muito ruim. Tinha um caminhão que foi doado para nós, mas parece que ele não tinha documento e ele era aqui da prefeitura. Foi o Gera que era o prefeito que passou para a agricultura familiar usar o caminhão. Nessa época eu vinha trabalhar na feira aqui na cidade. Eu plantava lá no sítio e vinha vender aqui na feira que era no sábado. Eu vinha e vendia feijão, farinha que eu plantava lá. Nessa época a gente trabalhava com pedido de licença, que foi um tal de Joaquim, quer dizer, nem sei se é Joaquim mas é diretor lá de Santos. Só sei que o Marcelo conseguiu muitas licenças. E nós trabalhávamos porque nós tínhamos licença. Essa licença foi através da prefeitura e do IBAMA que trabalhavam em parceria e então a gente conseguiu. E depois disso, nunca mais aconteceu nada e acabaram as licenças. Para conseguir a autorização tem que juntar muitas pessoas. Eu não sei porque isso não é falado no conselho. Eu devia ter falado. A coisa mais importante para nós, aqui, é a plantação. Porque, na verdade, todo mundo que mora lá, vem aqui na cidade buscar o açúcar, o café.... Lá no Santa Maria, toda vida foi assim como falei para você. Tinha uma necessidade de buscar um peixe, buscar uma ostra ... e isso era feito só por uma necessidade, entendeu como que é? Então a pessoa ia lá, buscava o peixe, a ostra, o camarão, o mexilhão. E mexilhão naquele tempo, ninguém comia. Mas tinha por demais, o mexilhão. E ninguém comia. Tinha muito. A ostra era a

\footnotetext{
${ }^{129}$ Centro de Estudos Ecológicos Gaia Ambiental. Associação privada que atua em favor e direitos socioambientais em Cananeia. Por meio de edital foi contemplada para a realização de projeto voltado para a agricultura familiar pelo Programa Territórios da Cidadania vinculado ao Programa Nacional de Desenvolvimento Sustentável dos Territórios Rurais do governo federal.
} 
mesma coisa. Então tinha muita coisa. Porque você tinha o arroz, tinha o feijão e tinha tudo. Então buscar ostra, é só quando tinha necessidade. Você ia buscar um peixe, quando tinha necessidade. E hoje acabou tudo isso. Não tem a roça, não tem o peixe e não tem mais nada. Proibiu-se tudo e está acabando. Quando não era proibido, tinha tudo, e tinha com abundância. Hoje é proibido, você tem que cuidar e tem que preservar, e você não tem nada. Por quê? Porque é a minoria que preserva, são os pequenos. E eles não são contados nisso. Agora, a maioria que são os grandes embarcadores $e$ industrialistas, eles é que desfrutam de todos esses bens preservados pelos pequenos. Ali não tem muito pescador. Na verdade, os pescadores que tem aqui são das cidades de fora. Aqui tem vários barcos grandes que pescam de fora. Eu, na verdade, só conheço o Edinho. Só escuto falar nele. Tem o outro também, que foi embora e que morreu. Os outros, eu não conheço. Eu sei que tem um monte de barcos agora. Eu não sei se é daqui de Cananéia ou se é de pessoa que vem de fora e que encosta ali para desembarcar. Eu sou pescadora. Eu tenho carteirinha. Mas todos os moradores tradicionais podem ir pescar. Porque se ele é morador tradicional ali daquele lugar... Eu vou falar uma coisa para você. Qualquer um que conhece o cara que está falando a verdade, está falando mentira, certo? O cara vai vir de São Paulo. Então você vai perguntar para ele: você nasceu aqui? Quem é a sua família e o seu parentesco? O que você faz? O cara não vai saber explicar. E você já vai saber que o cara não é dali, entendeu? Mas para isso tem que ter a fiscalização, que nós não temos. Se tivesse essa fiscalização que fosse em cima, fica bem mais fácil.

Aqui falta terminar minha casa ainda... aos poucos vou terminando. Aqui mora só eu e minha mãe. Tenho filhos mas nenhum mora aqui na cidade. Mora tudo em outro estado, em Joinville. Foram tudo embora. Os três. O mais velho é Abimael. O segundo é Abimanil. E o terceiro é Maicon. Eles trabalham lá. Dois trabalham na Tupi, que é peça para caminhão e para tudo. E o outro é cabelereiro, o mais velho. Um já faz treze anos que mora lá. Na verdade, o que ficou mais comigo lá, foi o caçula. O mais velho, quando eu plantava lá, ele ia ajudar a colher e carregar o saco de arroz. E o segundo ia só para passear mesmo. Nunca foi para morar. Eles nasceram aqui. E depois de certo tamanho, eles foram para lá. Inclusive o Maicon chegou até estudar lá. Os outros não porque já eram todos rapazes. O Maicon chegou a morar lá comigo, estudar... Não na escola de lá mesmo, mas ele vinha de lá e estudava no Porto Cubatão. ${ }^{130}$ Os outros dois ficavam aqui

\footnotetext{
${ }^{130}$ Porto Cubatão é um bairro de Cananeia com estrutura (escolas, postos de saúde, transporte), que
} atende parte da população das áreas mais afastadas. 
sozinhos. Eles já eram grandes. Quando eles eram pequenos, não. Nessa época já era só pesca. O trabalho nosso era só na pesca. É que praticamente foi nessa época, quando o meu menino nasceu, que foi a evolução da coisa.

Na época em que falei que começou a guerra dos bang-bang lá. Ele nasceu nessa época. Ele vai fazer 35 anos. Um nasceu em oitenta, e o outro nasceu em oitenta e um. Nós ficávamos aqui em Cananeia porque lá estava feia a coisa. É aquele velho ditado: é melhor que vão os anéis e ficam os dedos. Porque os dedos, uma hora você vai usar para por outros anéis. Com isso ficamos muito tempo sem plantar. Até os meninos ficarem grandes. Desde o meu pai temos casa aqui na cidade. Eu tinha a casa aqui, e trabalhava no sítio. Ficava um pouco lá, e um pouco aqui. A maioria do povo que está lá no sítio, todos tem casa aqui. E na época da plantação vai todo mundo para lá. Vai plantar uma banana, uma cana... Isso pode plantar. Porque é uma coisa que não precisa de queima. O problema é a queima. E você não pode roçar e não pode queimar. E a tiguera, não. Tiguera é mata baixa de dois e meio, dois metros e quinze. Isso chama-se tiguera. E isso você pode roçar, carpir... Isso não tem problema. Podemos plantar mas não é suficiente. O que dá numa mata boa, já não dá na tiguera. Não sai a planta e você perde a semente. Se você for deixar de plantar num mato virgem... Mato virgem é uma terra que você nunca mexeu ali. Aquela terra nunca foi usada para nada. E aqui, a gente chama mata virgem. E na mata virgem dá o dobro do que dá na tiguera. Na tiguera já está muito batida, muito surrada a terra. A mata virgem, não. Então depois foi só pescaria. Ostra, jerival, colocar espinhel... O espinhel é uma corda cheia de anzol, que você vai lá no mar, solta e deixa. Depois você vai lá e pega os bagres, cação, miraguaia, arraia...Até arraia pega no espinhel. A gente só nunca usou cerco. Eu acho que cerca é uma arma muito ingrata para nossa região aqui. Aqui do mar de dentro, apesar de ter muito cerco que as pessoas fazem, o cerco é como se você armasse um carreiro, e ali passa o pai, passa a mãe, passa avó e mata tudo. Tudo que cai ali, mata. Não vai sobrar nada, entendeu? E o cerco é a mesma coisa. Você faz o cerco, deixa lá e o peixe vai entrando, e vai só caindo. E dali você vai tirar tudo, com ova, sem ova... Por isso eu acho melhor o espinhel ou a pesca de rede mesmo. Eu acho que é melhor porque o cerco fica armado ali na água, tudo que passa ali, cai nele. A rede, não. A rede só pega se você por ela na água. E se ficar um mês, dois meses a rede em cima do barranco, ela não está fazendo nada. Agora, o cerco fica lá. Não tem como você trazer ele para cá todo dia. Ele é montado lá. É uma casa. É aonde os peixes vão e caem. Eu fui falar isso na reunião e quase apanhei! O cara ficou tão bravo. Depois ele me pediu desculpas. Mas lá na reunião 
é onde você vai levar as suas ideias e você tem que expor. Como se diz, é uma eleição. E a pessoa vai julgar se está certo ou se não está.

O conselho funciona pouco. Muito pouco. Mas eu sempre fui bem atendida. Esse é o meu jeito. Eu sou assim. Eu falo mesmo. Uma coisa que o meu pai falava era assim: não roube, não minta e nunca pega o que não é seu. Então, eu acho que é isso, sabe. Eu falo que a gente é livre. Eu não devo nada para você, e você não deve nada para mim. Eu não tenho o rabo preso com ninguém, e eu falar, não vai tirar pedaço e nem nada. Eu acho que é isso. Até o Mário é muito assim. Ele deixa muito a desejar, porque ele fala uma coisa, e depois ele quer voltar atrás. Não é assim. Sustenta o que você falou e o que você vai fazer. Poxa, assim começa a conquistar a população, começa a conquistar as pessoas que moram aqui, para as pessoas começarem a ter confiança nele. Para não ficar com aquele pé na frente, e outro atrás. Porque a gente coloca uma pessoa lá, para isso. Vamos falar assim, que a sua vida está na mão dele. O seu cotidiano está dependendo dele. Se ele não levar as coisas, vai se virar contra ele. Porque, de repente, vai um espírito de porco lá, e vai saber lá o que vai fazer para ele. Então é assim, né?

Ah, o conflito maior é com o Parque Lagamar. Na RESEX não tem tanto conflito. O Osmar é uma pessoa muito bacana. Eu gostei muito de trabalhar com ele. Ele tem vontade de fazer as coisas. Mas é como ele falou: não depende só de mim. Porque tem o Lagamar. E o Lagamar vem pedir muita coisa para ele fazer. Boa parte das reivindicações é no Lagamar que faz fronteira com meu sítio. Faz tempo que não vou ao conselho porque meu esposo faleceu faz um ano e quatro meses e eu também fiquei doente... E depois de tanta conversa, fiquei desanimada. Mas agora eu quero voltar porque tem dois filhos meus que estão interessados em voltar e mexer lá no sítio, então vou lutar por eles. Eu e meu esposo quando ele era vivo, a nossa paixão era o sítio, era a terra. A gente vinha aqui em casa e quando via já estava voltando porque não conseguia ficar sem ir lá. Cidade para a gente nunca foi aquela coisa, para nós não tinha como o sítio, era uma vida diferente... Para mim o pior aqui na cidade é o desassossego. Porque lá você sai, vai mexer com a horta, tem uma galinha para dar de comer, um porco para dar água, uma coisa a mais para fazer, uma planta... Porque aqui, eu levanto 8 horas, venho e faço o café e já está tudo ali. Lá eu torrava café, socava arroz, debulhava o feijão que eu plantava. Aqui a sua ocupação é só levantar, pegar e botar na panela. E lá não. E era gostoso porque era uma coisa assim do dia a dia, como se fosse uma roda que estava sempre girando. Era muito gostoso a vida no sítio e por isso que eu acho que as pessoas vivem mais. 


\subsection{Populações Tradicionais: Reconhecimento jurídico-político e Unidades de Conservação}

A Reserva Extrativista Taquari se sobrepôs aos territórios dos bairros do Taquari, Colônia Santa Maria e Cantagalo - Continente. Por meio de sua indignada narrativa, podemos compreender que a área onde se localiza o sítio de Noêmia não foi diretamente afetada pelo Parque Estadual do Jacupiranga, criado em 1969. As primeiras interdições legais à manutenção de suas atividades agrícolas estão associadas ao contexto dos anos de 1980, momento em que sua propriedade passa a ser inserida na APACIP.

O surgimento da Área de Proteção Ambiental Cananeia - Iguape - Peruíbe (APACIP) em 1984 representa uma primeira iniciativa política e legislativa direcionada para a amenização dos conflitos criados pelo embate entre a necessidade conservacionista de demarcação de áreas protegidas para fim de conservação ambiental, e os direitos e demandas das populações locais afetadas pelos impactos das leis ambientais. Seu surgimento na legislação brasileira como categoria de unidade de conservação, ainda que não apresente o uso do conceito de "populações tradicionais" determina que, quando houver interesse público, algumas áreas poderão ser declaradas como relevantes à proteção ambiental "a fim de assegurar o bem-estar das populações humanas e conservar ou melhorar as condições ecológicas locais "131. Com base nesse artigo, o decreto ${ }^{132}$ que cria a APACIP obteve respaldo jurídico para especificar as ações de proteção aos direitos histórico-culturais das populações que passariam a viver em seu interior ${ }^{133}$. Segundo Ferreira, ${ }^{134}$ a criação da APACIP ocorre como parte de um intenso processo de criação de unidades de conservação em todo o Vale do Ribeira que ocorre nos anos de 1980. Embora a unidade de conservação admita a ocupação humana e já esboce fundamentos

\footnotetext{
${ }^{131}$ http://www2.camara.leg.br/legin/fed/lei/1980-1987/lei-6902-27-abril-1981-371587publicacaooriginal-1-pl.html Acesso em setembro/2016.

${ }^{132}$ https://documentacao.socioambiental.org/ato_normativo/UC/1561_20140806_151342.pdf Acesso em setembro/2016.

${ }^{133}$ Dispõe sobre a implantação de área de proteção ambiental nos Municípios de Cananeia, Iguape, e Peruíbe, no Estado de São Paulo, e dá outras Providências.

Art. $1^{\circ}$ - Sob a denominação de APA CANANEIA-IGUAPE-PERUÍBE, fica declarada área de proteção ambiental, as regiões situadas nos Municípios de Cananéia, Iguape, Peruíbe, Itariri e Miracatu, no Estado de São Paulo, com as delimitações geográficas constantes do artigo $3^{\circ}$, deste Decreto.

Artigo 2 - A declaração de que trata o artigo anterior, além de possibilitar, às comunidades caiçaras, o exercício de suas atividades, dentro dos padrões culturais estabelecidos historicamente, e de conter a ocupação das encostas passíveis de erosão, tem por objetivo proteger e preservar.

${ }^{134}$ FERREIRA, Lucia da Costa. Dimensões humanas da biodiversidade: mudanças sociais e conflitos em torno de áreas protegidas no Vale do Ribeira, SP, Brasil. In: Ambiente e Sociedade. vol.7 no 1, 2004.
} 
de ordem socioambiental em sua legislação, em um primeiro momento de implementação, ela pouco representava para a população local. Segundo Noêmia, o período em questão inaugurou a época de perseguições promovidas pelo Instituto Brasileiro de Meio Ambiente e Recursos Naturais Renováveis (IBAMA) e pela polícia florestal, sendo esses os principais fatores que impediram a continuidade da agricultura, de atividades extrativistas (principalmente palmito e madeira) e de caça associadas por ela ao conceito de tradicional. Tais perseguições relacionam-se ao fato de que nos territórios inseridos na APACIP, além da legislação pertinente à APA, são implementados procedimentos técnicos e legais voltados para a proteção ambiental, como a lei de fauna de 1967 que proíbe a caça, a proibição da extração de palmito e caixeta na cidade de Cananeia a partir de $1968^{135}$ e o Decreto 750 de 1993. Esse decreto federal aplica normas rígidas de exploração e veda o corte, a exploração e a supressão de vegetação primária e em estágio médio e avançado de recuperação. Dessa forma, apenas áreas já utilizadas e que ainda não tenham se recuperado podem ser voltadas para a agricultura, o que é incompatível com a rotatividade das áreas de plantio da roça de coivara praticada na área. Segundo Moraes, o decreto 750 foi criado de forma emergencial, provisório e com falhas sobretudo no seu aspecto homogeneizador que não define os diferentes usos dos recursos naturais empreendidos por diferentes setores. Além disso, ressalta também tratar-se de um recurso legal apenas parcialmente cumprido diante das falhas de fiscalização. Segundo Noêmia e outros colaboradores como Carlos França e Armando Davi da RDS Itapanhapima, a fiscalização é feita de forma truculenta e desigual pela polícia florestal: os pequenos produtores e sitiantes são punidos, enquanto grandes empreendimentos não sofrem as ações das multas e perseguições, sendo este um dos exemplos por eles apresentados como casos de injustiça ambiental. Assim como em outras narrativas presentes neste trabalho, sua história apresenta um passado lembrado como um tempo em que, mesmo marcado por restrições materiais no que diz respeito aos produtos industrializados como brinquedos, roupas e calçados, tem como principal característica a abundância de roças, de alimentação e sobretudo, de liberdade. Para ela, assim como para outros colaboradores, o "parque" é um conceito genérico utilizado para se referir a todas as unidades de conservação em diferentes contextos. Significa a chegada de regras que foram criadas de forma autoritária, sem nenhuma consulta à população local ou respeito ao conhecimento tradicional aplicado em suas atividades econômicas e culturais. Ainda

${ }^{135}$ MOURÃO, op.cit.p.65. 
segundo Noêmia, um dos principais problemas da legislação ambiental refere-se ao não reconhecimento de técnicas agrícolas tradicionais como a coivara, que é a queima controlada de áreas de mata virgem realizada com o intuito de prepará-las para o plantio, o que acarreta em dificuldades para a obtenção de licenças ambientais que autorizem a produção de roças. Ela aponta para a diferença entre dois tipos de áreas utilizadas para o plantio: a coberta pela tiguera, vegetação de mata baixa em estágio de regeneração, e outras em que a vegetação nunca foi desmatada ou já se encontra em estágio avançado de regeneração, fazendo-se necessário o uso da coivara. Assim, mesmo a tiguera sendo autorizada, Noêmia argumenta que ela não é suficiente, posto apresentar baixos níveis de produtividade. Além disso, ela não vê a coivara como uma técnica responsável pela degradação ambiental. Pelo contrário, trata-se de uma rotação de áreas que permite a regeneração da mata local após o período de colheita, cuja utilização do fogo é bem controlada graças à utilização de técnicas tradicionais de manejo territorial. Como parte dos argumentos apresentados pela colaboradora em prol da manutenção das atividades locais, ela destaca também o respeito à natureza que pauta os conhecimentos apreendidos e reproduzidos por gerações em relação aos ciclos de caça e pescaria. Esse respeito se traduziria em normas costumeiras responsáveis por interdições das práticas durante os ciclos reprodutivos das espécies. Com base nessas interdições, haveria um controle em relação à caça e a pesca que equilibrariam a população dos animais e recursos pesqueiros, impedindo a degradação ambiental.

Constatamos, portanto, que o aspecto mais destacado em sua narrativa é a sua defesa das populações tradicionais, identificando-se como caiçara. Segundo ela, esse caiçara é um conservacionista cultural, ${ }^{136}$ posto que seus conhecimentos sobre seu território e os recursos naturais de que dispõe lhe permitem uma relação harmoniosa com o meio que ocupam. Tal identificação com o conceito nos remete a um debate crucial no que tange ao reconhecimento político e jurídico das populações tradicionais: serão elas conservacionistas naturais ou culturais, ou tal categoria constitui uma projeção políticaideológica ocidental que transfere para as populações rurais e povos da floresta uma imagem idealizada do bom selvagem? ${ }^{137}$

\footnotetext{
${ }^{136}$ FURLAN, Sueli. Florestas Culturais: Manejo Sociocultural, Sustentabilidade e Territorialidade. Agrária. São Paulo: No3, p. 3-15, 2006.

${ }^{137}$ Sobre o debate acerca das diversas visões que envolvem o conceito de populações tradicionais, ver: ADAMS, Cristina. As populações caiçaras e o mito do bom selvagem: a necessidade de uma nova abordagem interdisciplinar. Revista de Antropologia, São Paulo, USP, 2000, V. 43 nº 1.
} 
Os debates em torno da relação entre populações tradicionais e a conservação do meio ambiente se iniciam a partir do momento em que as florestas passam a representar não apenas uma fonte de recursos materiais, assumindo uma perspectiva de suporte de vida sob a ótica biocêntrica. Essas novas diretrizes vão nortear o centro das disputas ideológicas em impactante conferência sobre meio ambiente realizada vinte anos após Estocolmo: a Segunda Conferência das Nações Unidas sobre Meio Ambiente e Desenvolvimento, em 1992, mais conhecida como ECO 92. Na "Declaração do Rio de Janeiro sobre Meio Ambiente e Desenvolvimento" apresentam-se 27 princípios que deveriam nortear e fundamentar a legislação e gestão ambiental. Nesse documento, destaca-se a importância atribuída ao desenvolvimento sustentável, ao direito intergeneracional para o meio ambiente ecologicamente equilibrado, à participação social na gestão ambiental e ao acesso à informação ambiental. ${ }^{138} \mathrm{Na}$ mesma Conferência foi estabelecida a Convenção Sobre Diversidade Biológica (CDB), que assinalou importantes conquistas sobre os direitos aos recursos naturais, tais como a soberania dos Estados sobre os recursos biológicos e genéticos existentes em seus territórios, e visando sobretudo " $a$ conservação da diversidade biológica, a utilização sustentável de seus componentes e a repartição justa e equitativa dos benefícios derivados da utilização dos recursos genéticos." 139 Essas duas iniciativas que embasam a formulação de leis ambientais capazes de associar conservação da biodiversidade à justiça social para com os povos e populações detentores dos territórios a serem conservados e do reconhecimento de sua importância como agente de proteção, surgem em consonância com a Convenção 169 da

CUNHA, Manuela Carneiro da, ALMEIDA, Mauro W. Barbosa de. Populações Indígenas, Povos Tradicionais e Preservação na Amazônia. In: CAPOBIANCO, João P., R.et al (orgs) Biodiversidade na Amazônia Brasileira - Avaliação e Ações Prioritárias para a Conservação, Uso Sustentável e Repartição de Benefícios. São Paulo: Instituto Socioambiental e Estação Liberdade, 2001. p. 84-193. DIEGUES, Antônio Carlos (org). Etnoconservação: novos rumos para a proteção da natureza nos trópicos. São Paulo: Hucitec/Nupaub, 2000.

FERREIRA, Lucia da Costa. Dimensões humanas da biodiversidade: mudanças sociais e conflitos em torno de áreas protegidas no Vale do Ribeira, SP, Brasil. In: Ambiente e Sociedade. vol.7 no.1, 2004. FURLAN, Sueli. Florestas Culturais: Manejo Sociocultural, Sustentabilidade e Territorialidade. Agrária, São Paulo, N³, p. 3-15, 2006.

GERHARDT, Clayton. Pesquisadores e suas táticas discursivas no debate sobre populações tradicionais e proteção à biodiversidade. Desenvolvimento e Meio Ambiente, n. 21, p. 43-67, jan./jun. Editora UFPR, 2010.

OLMOS, Fabio. Populações Tradicionais e Biodiversidade. http://www.oeco.org.br/colunas/fabioolmos/21088-populacoes-tradicionais-e-a-biodiversidade/ Acesso em fevereiro/2017.

VIANNA, Lucila Pinsard. De invisíveis a Protagonistas: populações tradicionais e unidades de conservação. São Paulo: Annablume/Fapesp, 2008. p.45

${ }^{138}$ SANTILLI, Juliana. Socioambientalismo e novos direitos - Proteção jurídica à diversidade biológica e cultural, p.43-44.

${ }^{139}$ Idem p.44 
OIT (Organização Internacional do Trabalho) órgão multilateral ligado à ONU (Organização das Nações Unidas) de 1989:

A Convenção 169 sobre Povos Indígenas e Tribais em Países Independentes da Organização Internacional do Trabalho (OIT) aprovada em 1989, durante sua $76^{\mathrm{a}}$ Conferência, é o instrumento internacional vinculante mais antigo que trata especificamente dos direitos dos povos indígenas e tribais no mundo. Depois de quase 20 anos de sua aprovação, a OIT vem acumulando experiências na implementação dos direitos reconhecidos a esses povos sobre as mais diversas matérias, tais com o direito de autonomia e controle de suas próprias instituições, formas de vida e desenvolvimento econômico, propriedade da terra e de recursos naturais, tratamento penal e assédio sexual. ${ }^{140}$

Nesse mesmo contexto de redefinição de princípios sobre a relação entre conservação e os direitos das populações tradicionais, o processo de redemocratização do Estado Brasileiro institucionalizado pela elaboração da Constituição de 1988 representa um importante marco nacional. Segundo Santilli:

A fase final do regime militar havia sido marcada pela emergência de inúmeros movimentos sociais e populares, que trouxeram à cena política não apenas as questões das liberdades democráticas, mas também um conjunto de bandeiras e reivindicações setoriais. ${ }^{141}$

E ainda:

Nesse contexto, um conjunto de temas que emergiram no cenário mundial das décadas imediatamente anteriores acabou legitimado e inserido na pauta dos trabalhos constituintes dos direitos das minorias, especialmente mulheres e negros, combate à discriminação de gênero e ao racismo, proteção aos portadores de deficiências físicas, e aos direitos de crianças, adolescentes, idosos e índios, reconhecimento da diversidade étnica e cultural, proteção ao patrimônio público e social, ao patrimônio cultural e ao meio ambiente. ${ }^{142}$

O surgimento do socioambientalismo, visão que alia no mesmo campo de ação política a proteção da biodiversidade e da sociodiversidade, do ponto de vista institucional pode ser visto como uma conquista de movimentos sociais ligados aos direitos territoriais

\footnotetext{
${ }^{140} \mathrm{http} / / / \mathrm{www}$. socioambiental.org/inst/esp/consulta previa/?q=convencao-169-da-oit-no-brasil/aconvencao-169-da-oit Acesso em fevereiro/2017

${ }^{141}$ SANTILLI, Juliana. Socioambientalismo e novos direitos - Proteção jurídica à diversidade biológica e cultural, p.56.

${ }^{142}$ Idem p. 56
} 
e ambientais, da sociedade civil (sobretudo organizações não governamentais) e de instituições nacionais e supranacionais, permitindo um avanço na legislação relativa à manutenção de populações em seus territórios. Dessa forma, a ressignificação do conceito de populações tradicionais como categoria política e jurídica se deu a partir desse cenário de disputas políticas que promoveu, em alguns casos, processos de resistência e identificação com o conceito frente à problemática comum do não acesso aos direitos territoriais.

Diante desse cenário, a definição de populações tradicionais representa uma das grandes questões para a legislação ambiental brasileira relativa aos direitos de permanência e uso de territórios. Segundo Cunha e Almeida, inicialmente esse conceito surge atrelado à ideia de "nativo", ou seja, aquele que nasceu no lugar, mas atualmente, ele é encarado de forma mais complexa. As categorias étnico-culturais às quais as populações foram adequadas de forma abrangente (caiçaras, no caso deste estudo) converteram-se em instrumentos políticos e jurídicos capazes de respaldar a mobilização de diversos grupos ameaçados pela especulação imobiliária e pelas políticas de conservação ambiental. Ao instituir a possibilidade de acesso à propriedade coletiva, incentivou a valorização de modos de vida e costumes antes vistos como atrasados. Assim:

\begin{abstract}
"Isto não é tão novo assim. Termos como "índio", "indígena", "tribal", "nativo", "aborígene" e "negro" são todos criação da metrópole, são frutos do encontro colonial. Contudo, embora tenham sido genéricos e artificiais ao serem criados, esses termos foram sendo aos poucos habitados por gente de carne e osso. É o que acontece, mas não necessariamente, quando ganham status administrativo ou jurídico. Não deixa de ser notável o fato de que com muita frequência os povos que começaram habitando essas categorias pela força tenham sido capazes de apossar-se delas, convertendo termos carregados de preconceito em bandeiras mobilizadoras. Nesse caso a deportação para um território conceitual estrangeiro terminou resultando na ocupação e defesa desse território. É a partir desse momento que a categoria que começou por ser definida "em extensão" começa a ser redefinida analiticamente a partir de propriedades." 143
\end{abstract}

A ideia de uma categoria "em extensão" foi significativa na fase de consolidação jurídica, na medida em que permitiu a inclusão de muitos grupos ameaçados pelo quadro

${ }^{143}$ CUNHA, Manuela Carneiro da, ALMEIDA, Mauro W. Barbosa. Populações indígenas, povos tradicionais e ocupação da Amazônia. p.187. 
de concentração e conflitos fundiários nas áreas protegidas, como ocorreu na área rural de Cananeia. Em se tratando de uma questão que afeta todo o território nacional, foi pontualmente importante que a normatização legal fosse capaz de criar uma espécie de categoria suporte que embasou ao mesmo tempo contextos muitos variados, de povos com diferentes problemáticas e em diversos estágios de organização coletiva. Frente a essa diversidade, os critérios de pertencimento foram norteados pela identificação de algumas características fundamentais sob a perspectiva da conservação cultural e ambiental.

O que todos esses grupos possuem em comum é o fato de que tiveram pelo menos em parte uma história de baixo impacto ambiental e de que têm no presente interesses em manter ou em recuperar o controle sobre o território que exploram. Mas acima de tudo, estão dispostos a uma negociação: em troca do controle sobre o território, comprometem-se a prestar serviços ambientais. ${ }^{144}$

Essa visão progressista e abrangente em torno do que esse conceito significa culturalmente e de como podemos transpor tal noção para o campo jurídico, está longe de representar uma unanimidade no meio ambiental. Segundo Ferreira, as diferentes defesas ideológicas sobre a compreensão do que é conservar o meio ambiente podem ser analisadas no processo de criação do SNUC (Sistema Nacional de Unidades de Conservação) que apresenta a regulação sobre unidades de conservação em âmbito nacional e passa a ser responsável por estabelecer critérios e normas para a criação, implantação e gestão das unidades de conservação. Aprovado em 2000, seu primeiro projeto começou a ser elaborada em 1988 e envolveu disputas entre deputados, organizações não-governamentais e agências ambientais governamentais. Dentre essas disputas, destacamos a divergência no que se refere à visão preservacionista, ou seja, que acredita que os propósitos de proteção ambiental das unidades de conservação não são compatíveis com a presença humana, representada sobretudo pelo deputado Fabio Feldmann, e a visão conservacionista, que pretende compatibilizar o ideal de conservação ambiental à presença humana, representada pelo deputado Fernando Gabeira. Segundo Ferreira:

O Deputado Feldmann entregou à CDCMAM (Comissão de Defesa do Consumidor, Meio Ambiente e Minorias), no final de 1994, um

${ }^{144}$ Idem p. 187 
Substitutivo Preliminar. Mercadante (1999) julgava a proposta do deputado preservacionista, conforme o espírito do projeto original do Poder Executivo. Em 1995 o Deputado Fernando Gabeira passou a ser o novo relator. Neste período promoveu-se um amplo debate sobre o projeto de lei do SNUC, inclusive para analisar experiências concretas de conservação envolvendo populações consideradas tradicionais ou simplesmente rurais, a presença humana em UCs e a proposta de criação das Reservas Particulares do Patrimônio Natural - RPPN. ${ }^{145}$

O SNUC foi a primeira tentativa de definir legalmente o conceito de populações tradicionais de forma abrangente e um tanto quanto vaga. Tem o mérito de ser a primeira tentativa de ordenamento jurídico pátrio que apresentou a conceituação de "populações tradicionais" ${ }^{\prime 146}$. Em seu artigo 2, inciso XV do referido conjunto de leis do projeto original, temos uma definição legal de populações tradicionais, que no entanto foi vetada. O argumento e justificativa para tal veto é o fato de que a definição mostra-se por demais abrangente. Sob a hermenêutica jurídica, a interpretação de tal inciso poderia incluir boa parte da população brasileira. A seguir o texto sujeito ao veto:

\footnotetext{
Art. 2 Para fins previstos nesta lei, entende-se por:

XV - população tradicional: grupos humanos culturalmente diferenciados, vivendo há, no mínimo, três gerações em um determinado ecossistema, historicamente reproduzindo seu modo de vida, em estreita dependência do meio natural para sua subsistência e utilizando os recursos naturais de forma sustentável.
}

Apesar de vetar a conceituação jurídica de população tradicional, o sistema apresenta duas novas categorias de unidade de conservação sustentáveis: Reserva Extrativista e Reserva de Desenvolvimento Sustentável. Dessa forma o SNUC omitiu o conceito de população tradicional ao mesmo tempo em que criou duas categorias de unidade de conservação voltadas para o propósito de assegurar os seus direitos. Tal contradição exigiu que uma outra legislação fosse criada de forma complementar ao SNUC, o que ocorreu via decreto n.6.040 de fevereiro de 2007 que institui a Política Nacional de Povos e Comunidades Tradicionais ${ }^{147}$. A importância desse decreto reside justamente no fato de que assinala não apenas o reconhecimento, ou seja, o direito de

\footnotetext{
${ }^{145}$ FERREIRA, Maria Lucia, OLIVEIRA, Simone de, SIVIERO, Simone Vieira de Campos, SILVEIRA, Pedro Castelo Branco, OLIVEIRA, Vivian Gladys de, MENDES, Ana Beatriz Vianna, PINTO, Anaisa de Oliveira. Conflitos Sociais em Áreas Protegidas no Brasil: Moradores, Instituições e Ong's no Vale do Ribeira e Litoral Sul, SP. Revista Idéias. 2001. 8(2): 115-150. p.9.

${ }^{146}$ AMARANTES, Caroline Bastos do. Reconhecimento Jurídico-Normativo das Populações Tradicionais Pelo Estado Brasileiro: uma revisão. p.04

147 http://www.planalto.gov.br/ccivil_03/_ato2007-2010/2007/decreto/d6040.htm Acesso em março/2017.
} 
existir, como aponta para a necessidade de formulação de políticas públicas voltadas para a criação de condições objetivas para que essas populações possam não apenas permanecer nos territórios, mas proteger suas práticas culturais dialogando com a proteção da biodiversidade local.

Art. 3 Para os fins deste Decreto e do seu Anexo compreende-se por:

I - Povos e Comunidades Tradicionais: grupos culturalmente diferenciados e que se reconhecem como tais, que possuem formas próprias de organização social, que ocupam e usam territórios e recursos naturais como condição para sua reprodução cultural, social, religiosa, ancestral e econômica, utilizando conhecimentos, inovações e práticas gerados e transmitidos pela tradição;

II - Territórios Tradicionais: os espaços necessários a reprodução cultural, social e econômica dos povos e comunidades tradicionais, sejam eles utilizados de forma permanente ou temporária, observado, no que diz respeito aos povos indígenas e quilombolas, respectivamente, o que dispõem os arts. 231 da Constituição e 68 do Ato das Disposições Constitucionais Transitórias e demais regulamentações; e

III - Desenvolvimento Sustentável: o uso equilibrado dos recursos naturais, voltado para a melhoria da qualidade de vida da presente geração, garantindo as mesmas possibilidades para as gerações futuras.

O respaldo da legislação federal ampliou a legitimidade legal das lutas identitárias e territoriais em todo âmbito nacional e consequentemente também na região do Vale do Ribeira no Estado de São Paulo. Dessa forma, ainda que para os nossos colaboradores, a exemplo de Dona Noêmia, as novas categorias de unidade de conservação sustentáveis na qual foram inseridos (primeiramente a Área de Proteção Ambiental e depois à RESEX) continue sendo associadas à ideia repressiva e genérica de "parque", as categorias derivadas do conceito de população tradicional, como "caiçara", adquirem teor político na medida em que é associada à defesa dos direitos fundiários e de acesso aos recursos naturais do território. É munida por esse conceito com a qual se identifica que Noêmia constrói a crítica à instituição de unidades de conservação em seu território, processo considerado por ela arbitrário, injusto e incapaz de contemplar as necessidades das populações locais por meio da gestão compartilhada.

A seguir apresento a trajetória de vida militante do senhor Carlos França e de Ivone França, forjada em meio aos muitos conflitos fundiários e institucionais da área rural de Cananeia, onde ocorre a sobreposição de territórios tradicionais e unidades de 
conservação (UC’s). Assim como Noêmia, Carlos França, responsável pela maior parte da narrativa, incorpora à sua história a reinvindicação dos direitos atrelados à sua condição jurídica e política de "população tradicional". Ao mesmo tempo promove duras críticas ao modelo de gestão ambiental a que estão submetidos como beneficiários das unidades de conservação, mesmo de cunho sustentável. Morador do bairro de Santa Maria diretamente afetado pela criação do Parque Estadual do Jacupiranga, atualmente seu sítio encontra-se na área de amortecimento do Parque Lagamar, sendo este reconhecido como beneficiário da Reserva Extrativista Taquari, ambas unidades de conservação que compõem o MOJAC (Mosaicos de Unidades de Conservação do Jacupiranga). Sua longa história familiar e pessoal de resistência e permanência no território permite um melhor entendimento sobre as dificuldades de participação política nas decisões relativas às unidades de conservação, mesmo para pessoas que, como ele, procuram constantemente engajar-se nos espaços políticos que possam assegurar os direitos das populações tradicionais diretamente afetadas pelas limitações impostas pela legislação ambiental. 


\section{Mosaico de Unidades de Conservação do Jacupiranga.}

Fonte: Instituto Socioambiental, 2008.

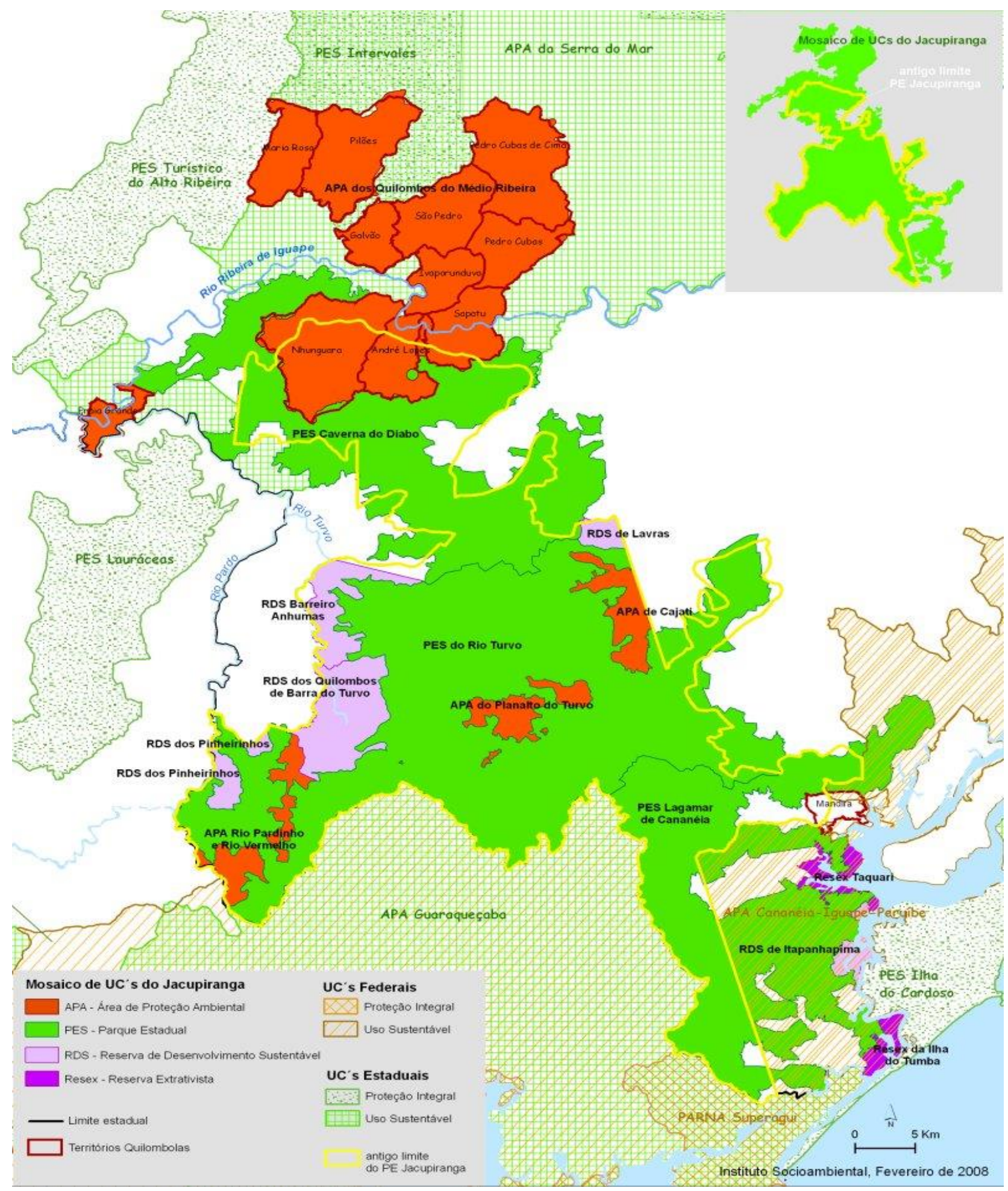




\section{Carlos Franca e Ivone Franca}

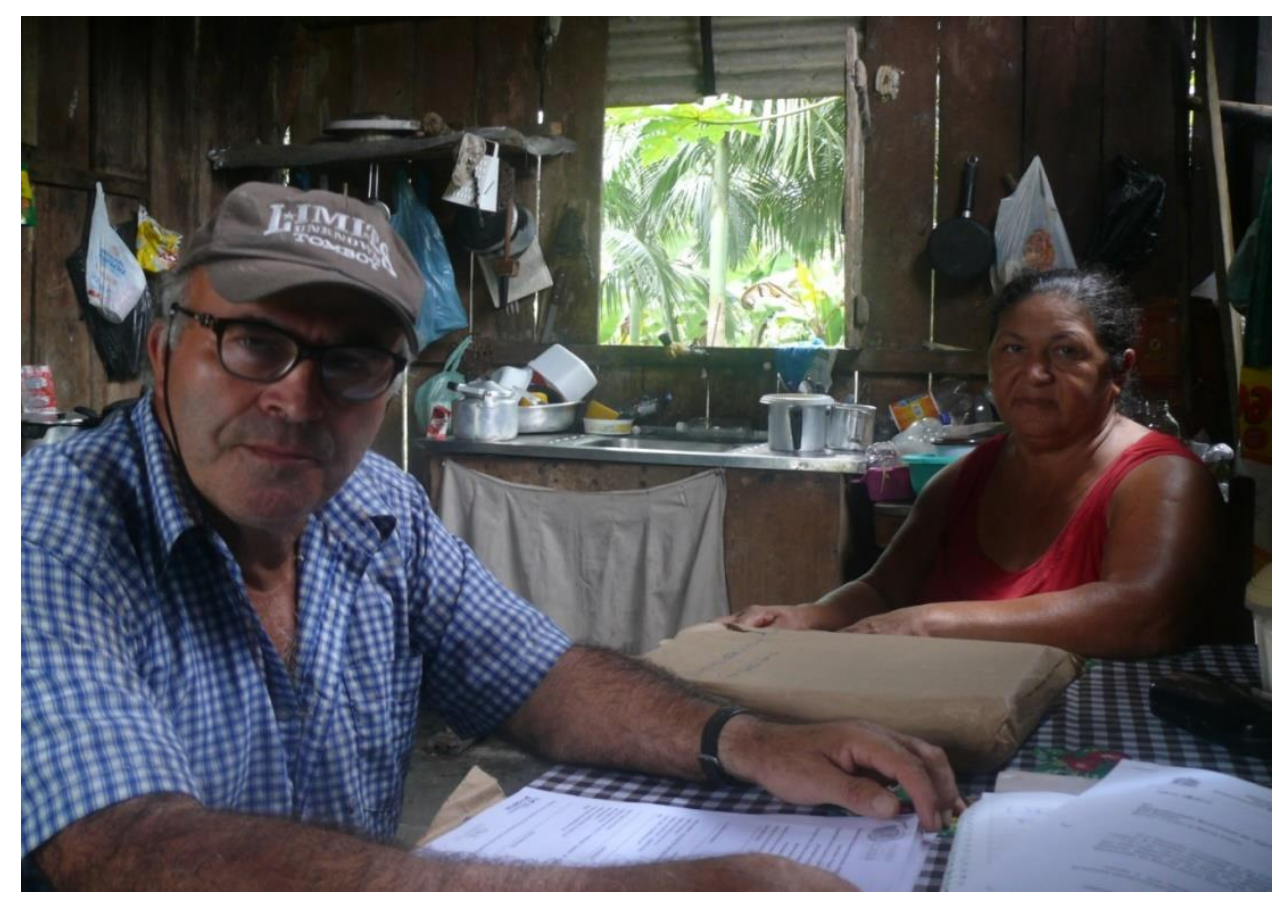

Carlos França ou Seu Carlinhos como é mais conhecido na região é um dos participantes mais ativos do Conselho gestor e de diversas mobilizações das famílias da região. Esposo de Dona Ivone França e morador do Bairro Santa Maria que fica no entorno da RESEX Taquari ele, sua família e seus vizinhos foram afetados diretamente pela criação do Parque Estadual do Jacupiranga e posteriormente pelo Parque Lagamar. Descendente direto de imigrantes franceses que se estabeleceram na região no século XIX e da cultura agrícola que permeava todo o modo de vida dessas pessoas, luta constantemente pelos direitos das populações tradicionais da região e atualmente organiza uma associação de moradores do bairro Santa Maria e Taquari buscando viabilizar a manutenção da cultura agrícola da região. Entrevista realizada em dezembro de 2015.

\section{"Isso é a tradição e a necessidade." \\ Carlos França}

Eu sou morador do Santa Maria, nascido aqui na colônia Santa Maria, me criei. A minha família é daqui, eu sou Carlos França e o meu pai é Jeremias França, a minha mãe é Celina Paiva França, e minha esposa Ivone Pedro França. A gente tem uma longa história aqui. A gente é comunidade tradicional, no caso. Eu trabalho com comunidade 
há mais de trinta anos, lidando com grileiro, lidando com associações, moradores e grupos. Hoje nós temos o parque aqui de Jacupiranga e do Lagamar de Cananeia. Temos a RESEX ${ }^{148}$ que faço parte, o parque que também faço. Temos o grupo do MAB que é o Movimento dos Atingidos por Barragens do qual também faço parte. Temos um grupo com quase sessenta famílias. E o que eu acho mais difícil aqui é que a gente não tem apoio das cidades, das organizações e dos poderes públicos. Hoje você quer fazer uma roça e você não consegue licença, você quer fazer uma canoa e você não consegue licença. Você mesmo viu o problema do rapaz lá pela RESEX, que ele queria fazer uma canoa para pescar e não pode, porque não mandaram a licença para ele. Nós aqui somos a mesma coisa, se fizer, a polícia ambiental prende. E nós temos muitas invasões de casa pela própria polícia ambiental, o que não tem nada a ver com o trabalho deles. $O$ trabalho deles é cuidar do mato, cuidar da reserva e não entrar dentro da casa dos outros sem autorização do poder judiciário, do Fórum, do juiz. Então essas coisas fazem com que muitas pessoas saiam dos lugares, se retirem e deixem as comunidades, e vão para as cidades ou outros lugares e lá, eles não têm uma estrutura.

Quem sai daqui para ir para a cidade, vai sem estrutura. A vida dele aqui é outra, e lá vai ser bem diferente. Muitas pessoas que saíram daqui, hoje a família vive preso na cadeia porque não tem com o que trabalhar, aí eles saem e vão para a bandidagem. E o que eu gostaria é que os poderes públicos, a prefeitura, o Instituto Florestal, o Instituto de Pesca organizasse bem a pesca. Porque tem muitas pessoas que sofrem por causa da pesca e não tem apoio nenhum. Os caras dão mais apoio para esses barcos grandes, $e$ para os pequenos eles não dão apoio. Então a dificuldade nossa é essa. E não dizendo que a gente não mora numa área boa, porque é uma área muito boa, já é muito antiga e de tradição, né? O nosso terreno é de 1880, por aí. O primeiro da família foi o Lima da Silva França. Ele comprou esse terreno de um outro proprietário, de um primo dele, entende? Que já era mais antigo ainda. Era o meu bisavô.

Ele é descendente de francês, só que é casado com brasileira. E nós já somos brasileiros, no caso. Meu avô, meu pai e eu, nós somos brasileiros. Mas pelo tempo que a gente convive aqui, a gente é tradicional, né? A gente curte muito a tradição. A maneira de nós vivermos tradicionalmente é você roçar, plantar do jeito que você foi acostumado. Hoje eles querem mudar essa cultura, mas o povo não consegue se adaptar com essa cultura, porque a nossa região aqui, ela é uma região muito úmida. E tem lugar que se

\footnotetext{
${ }^{148}$ Reserva Extrativista
} 
você não queimar e não fizer fogueira, você não consegue plantar. E a gente também não tem maquinário também para trabalhar sem a queimada. Então, se torna difícil. A nossa cultura aqui é arroz, feijão, milho, mandioca... são coisas que você sempre tem que queimar para plantar. A mandioca, o arroz e o feijão é plantado em área baixa. É área que às vezes é difícil até você trabalhar com trator. Na nossa região aqui, que tem muita várzea é muito difícil trabalhar. E a gente ficou muito tempo sem ter licença para plantar, sabe? E as madeiras cresceram muito, e hoje é difícil tirar essas madeiras mesmo com a máquina para limpar. É difícil você limpar a terra. E às vezes a gente não planta porque não tem como queimar, não tem como limpar essa terra. Nessa área que a licença permitia, a gente conseguiu um direito de queimada. Era quatro hectares, três hectares, dois hectares, era dependendo da situação da pessoa. Às vezes eu conseguia quatro, o meu filho conseguia quatro, a minha mulher conseguia quatro, então daria doze hectares. Não era tão suficiente para você trabalhar e ter uma renda maior, mas, para você se manter, dava. Só que agora não temos nem doze, nem treze, nem um. Não temos nada.

Nós paramos porque nessa licença tinha um prazo, então terminou o prazo e tinha que renovar ela, e quando a gente foi para renovar, não conseguimos mais. Não conseguimos renovar porque o próprio IBAMA não liberou mais para nós. Não é medo, porque a gente sabe que é um direito nosso. Só que eles ultrapassaram esse direito, eles não autorizaram mais a licença para nós. Quando nós pedimos, o diretor do parque foi muito claro, ele falou que nós tínhamos todos os direitos de roçar, de ter vida digna de plantar para sobrevivência. Ele foi o primeiro diretor que liberou as licenças para nós, e ele falou que era um direito nosso. E ele falou que não tinha como não liberar essa licença. Só que o segundo diretor, ele já foi diferente. Primeiro ele não queria liberar, depois ele liberou e a gente pediu quarenta hectares de licença, e ele já achou que era muito, mas nós temos muito mais família. Então ele achava que ia estragar muito trecho de terra, e a turma não ia respeitar aqueles direitos. Mas a gente aqui sempre respeitou, a gente sabe onde pode plantar, onde pode roçar e onde não pode como beira de rios, cachoeiras... Todos os espaços que é determinado pela lei, a gente sabe que não pode mexer com ela. Então, ele foi um pouco rigoroso com o povo e não liberou mais. Então a gente não fez mais roça, porque quando você faz, você é multado. Hoje você não pode se esconder por causa do satélite, tem o aparelho que já acusa. Então não tem como você fazer. E hoje o povo não planta. Se você andar nas casas você vai ver que tudo é comprado. Vivendo numa área de fartura, tudo o que tem é comprado. Aqui era uma colônia agrícola, e hoje você não vê um nada plantado. Hoje, na verdade, o cara faz no 
máximo uma empreitadinha para um sitiante. Por exemplo uma empreitada quando roça pasto. Porque esses caras grandes, eles ainda fazem. Eles não cumprem a lei, a gente que quer cumprir a lei, não consegue. Eles não cumprem a lei. Quando você chega na estrada ali na beira do Taquari, você vê muito pasto ali, e são de pessoas de fora, não são de comunidades tradicionais. A comunidade tradicional, quando você olha na casa dele é só mato. Por quê? Porque ele tem medo de tomar uma multa. E os caras não, eles não têm medo de tomar uma multa. Primeiro que eles compram os caras, hoje o dinheiro fala mais alto, e a gente não tem dinheiro para isso. Se a gente tivesse dinheiro, a gente comprava mercadoria e não ia roçar. O meu cunhado mesmo, ele levou uma multa de três mil reais, sendo que ali era tiguera e banana. Tiguera é esse matinho baixo. Ele tinha um bananal e um pedacinho de tiguera, aí ele roçou para plantar, só que ele foi multado em três mil reais. A gente recorreu e tudo, mas ele foi multado. Enquanto outros grandes pintam e bordam e não são punidos. Tem o Valter aqui, que ele já comprou uma fazenda feita, mas alguém formou essa fazenda. Eu fiz uma denúncia que nem levaram em conta. E nós que queríamos pedir uma licença para porto de areia manual, eles falaram que não podia fazer porque ia mexer com o rio e tal. Só que lá tem o seu Antônio que tem a fazenda com a fábrica de pupunha, e tem um enorme tanque ali perto do trevo que fica na frente dos caras, e os caras não veem aquilo ali. Quando você sai ali, aquilo ali é uma represa e as autoridades não veem, e a gente não foi ouvido, entende? Então, se torna difícil. Existe uma desigualdade entre o pequeno agricultor e o grande agricultor. E ainda existe uma coisa: esses pequenos agricultores são todos profissionais, e esses grandes agricultores são pessoas que estão chegando agora, são terceiros. A pesca era só para comer. Eu vou pescar assim, para o meu uso e às vezes quando sobra, para as minhas vizinhas eu vendo um pouquinho. Mas, é mais para o meu uso. Aqui tem bastante pesca. Todo mundo faz a sua pescaria. Pesca no mar. A gente pesca no rio também. Até hoje tem a reserva do Taquari, que é a área que a gente pesca no rio Taquari também. Tem diversos tipos de peixes aqui. No rio tem o robalo. E mais tipos de robalo que não conheço. Tem a peba, tainha, parati, bagre... No mar tem carapeva, corvina, caranha... Tem diversos peixes grandes também, que eu não me lembro o nome, mas que é tudo no mar que a gente pode pescar. E no rio são esses peixes pequenos. E no rio de água doce também tem o lambari, jundiá... Isso é na nossa linguagem, né? Mas no nome comercial, eu não sei como é que é. É igual existe o bagre, que a gente chama de bagre do rio e bagre de água doce. Tem diversos tipos de peixe de água doce. Tem o bagre, o congro, jundiá, mandi... São tudo de uma espécie, e cada um tem um nome. Mandi é um tipo de 
bagre. É o mais pequenininho que tem, mas é na agua doce. Agora, na água salgada é o congro, o mais pequeno. Então a gente vive disso aí. Para cá, teve uma época que a gente tentou trabalhar com turismo rural. A gente começou a trazer turista, e eu sou monitor ambiental também. E sempre vinha gente, e a gente tinha uma renda. Só que agora com esse prefeito, parou tudo. O departamento de turismo não funciona. A gente tinha uma parceria. A gente fez um trabalho de turismo rural junto com o departamento de turismo da prefeitura, no caso. Então, eles corriam atrás dos grupos para mandar para cá, e a gente monitorava. A gente recebia os grupos e levava nas cachoeiras, nas trilhas. E isso é um meio também, de entrar uma renda.

E hoje a gente tenta plantar pupunha, né? Hoje a gente trabalha com pupunha. Fizemos uns cursos de pupunha, o prefeito deu dois cursos, como você plantar e como você comercializar. E hoje está sendo o forte da gente. A turma já está vendendo pupunha. Nós temos um pouco. Esse que almoçamos hoje é pupunha de plantio nosso. Então essas coisas é o que aumenta a renda das pessoas. Você recebe um pouquinho de cá, um pouquinho de lá. E tem a renda das pessoas que são aposentadas também. Não dá medo de plantar porque a pupunha é liberada, e para você plantar a pupunha não precisa limpar a terra. Você bosqueia a terra e planta. Só que a gente tem uma maneira de trabalhar sem usar agrotóxico e se você trabalha assim, você tem que usar. E hoje na pupunha, ela não é orgânica, hoje a gente já usa adubo. E o arroz, o feijão e a mandioca que às vezes a gente planta, é tudo orgânico. Farinha, feijão e tudo que a gente come é orgânico.

Isso é a tradição e a necessidade. Existe uma necessidade de você aprender, e uma obrigação também porque se você mora no sítio, tem que aprender a manejar o sítio. Então a gente aprendeu com os pais e com os avós. Eu com 7, 8 anos, eu já vivia na agricultura trabalhando. Eu estudava e trabalhava, então já vem de berço isso. E a pesca é a mesma coisa, porque antes não tinha estrada aqui, o nosso caminho era na pura água. Você descia o rio de canoa, descia e chegava lá no Carapara, pegava a canoa e ia para Cananéia no remo. Era o único jeito de chegar. Isso foi até 1980, 1970. E tinham pessoas que tinham motor também. Uns iam no remo, e outros iam no motor. A minha juventude foi tudo andando ou indo para a cidade no remo (risos). Se você queria ir para lá, você tinha que ir no remo. Nós íamos toda semana. Toda semana eu e meu pai levávamos cinco ou seis porcos para vender na cidade. Nós morávamos no outro sítio que hoje está dentro do parque, do Lagamar. Então, nós criávamos muito porco e plantávamos muito milho. Nós tínhamos um paiol de dez de comprido e oito de largo, 
que a gente enchia de milho e de arroz. Batia aquela lavoura e levava para vender na cidade, e a gente ia de canoa no remo. Agora facilitou porque a estrada está na porta de casa e fica mais fácil vender, mas a gente não tem essa liberdade. Às vezes a turma pergunta para mim: mas hoje é muito melhor, porque naquele tempo era difícil demais. E, eu digo que não, que naquele tempo era muito melhor. Porque você não precisava ir no mercado comprar o arroz, comprar o feijão, comprar a farinha e comprar o açúcar. Eu fui criado com açúcar de cana, eu fui criado com garapa e com o café da lavoura. $O$ açúcar de casa, você moe a cana. Nós tínhamos um cilindro, um engenho moído com cavalo de três eixos. Você põe a cana, e o cavalo vai rodando e moi e cana. Aí, a gente tinha tacho, que a gente jogava lá dentro, e aí você vai apurando até fazer o melado, porque nós vendíamos muito melado também. E quando você quer fazer o açúcar, aí você deixa apurar mais. Quando está terminando de apurar, você joga num encerado, numa lona ou numa gamela de madeira, que ela enxuga e seca aquilo ali. E depois vira uma pedra, você põe no pilão, quebra ele e vira tudo pedacinho. Vira um açúcar mascavo. A gente empacotava tudo aquilo em pacotinho de um quilo e levava para a cidade. Era de vinte, trinta pacotes. Naquela época não era muita gente que comprava. Porque mesmo na cidade, as pessoas tinham a cana e sabiam fazer o açúcar dele.

A mandioca, no caso, você lava ela bem lavado e tira aquele barro, tira as pontas dela e tudo, então você põe no saco e põe numa lagoa. Nisso você deixa ela uma semana lá, ela amolece, e isso se chama mandioca curtida. Então tira, mói ela e põe no tipiti ${ }^{149}$, leva para prensa ou burro. O burro, você faz um buraco num pau, amarra um gancho, embaixo você arruma uma tábua e carrega com pedra. E tem a prensa que você roda com o eixo. Então você prensa ela e faz o biju de mandipuva, faz a berereca e faz a farinha d'água. Essa berereca no caso, você mõe a massa e põe torresmo, ovos de galinha e faz uma misturada. Ela é recheada. Mas é muito bom demais.

Nesse trabalho de turismo rural que a gente tinha, a gente mostrava esse tipo de coisa. Se você for lá no museu municipal, você vai ver um folder na parede com todos eles arrancando mandioca e fazendo biju. Você vai ver a Ivone, a Adélia, a Tuca... Quando a gente fazia feira, levava essas coisas para vender. Na época da feira era muito bom, porque a gente tinha tudo e levava tudo para vender. Levava o biju de massa, o biju de goma, o biju de milho, tapioca, biju de arroz, cuscuz de massa e de arroz, farinha, aipim, batata, inhame, cará... A gente levava tudo. Depois eu vou mostrar para você onde

\footnotetext{
${ }^{149}$ Cesto caiçara vazado que, quando prensado, o excesso de água da massa de mandioca saia deixando a
} massa menos úmida para ser torrada. 
a gente tinha plantado, e que até hoje tem. E dava para a gente tirar um salário bom no mês. E depois o prefeito perdeu. E a maioria que está na cidade não se interessa por quem está no sítio, e o prefeito hoje, ele só vive pela cidade, e aqui pelo continente é difícil. Não tem um apoio da prefeitura no continente. Tem um vereador brigando contra oito. É muito trabalhador, só que ele não tem apoio. Ele trabalha com a comunidade, é o Carlos Caetano ${ }^{150}$. Trabalha com a comunidade desde que conheço ele há mais de quarenta anos. Mas só que ele não tem apoio. É um contra oito, então se torna difícil. Nós formamos uma associação e não chegamos a registrar ela, e eu tenho ata dela ainda. Só que a gente tinha o sindicato da agricultura familiar da Vale ${ }^{151}$, que dava muito apoio para nós. E também tínhamos o caminhão da prefeitura que vinha buscar a mercadoria. Isso aí foi feito através de mim e do próprio prefeito. Eu juntei todas as comunidades e conversamos entre nós, de Taquari, Santa Maria, Rio das Minas, Rio Branco, Aroeira... A gente formou um grupo grande, e tinha mais de vinte pessoas que fazia a feira. E entramos em conversa com o prefeito, porque a gente pediu e foi uma promessa na campanha dele. Então a gente foi cobrar e ele cumpriu essa promessa. Durante os quatro anos dele foi excelente, a gente teve a feira normal, aí na hora que mudou de prefeito tiraram o caminhão.

Umas vinte famílias participavam da feira. Todas elas produziam de tudo e vendiam de tudo. Levava galinha e só não levávamos porco, porque eu moro num lugar mais baixo, se torna mais difícil para criar. A cheia quando enche, você tem que erguer o chiqueiro e fazer alto. Então se torna difícil. Essa questão da licença é um ponto bom. Eu vendia o arroz integral e muitas pessoas vendiam o arroz e o feijão integral, porque quando a gente tinha licença, a gente conseguia plantar. Depois a gente perdeu a licença, terminou o prazo dela, e a gente não conseguiu mais renovar. Então ficamos sem licença e ficamos sem plantar. Aí também não tinha mandioca. A mandioca, se você não queimar ou não passar um trator para limpar a terra, você não consegue plantar. A não ser que seja um pedaço muito pequenininho. E para você trabalhar com agricultura num pedacinho muito pequenininho, não dá nem para você comer. É que nem agora, nós temos a associação, e nós estamos brigando para conseguir essa licença porque a gente tem uma proposta com a prefeitura na merenda escolar, para a gente plantar e vender

\footnotetext{
${ }^{150}$ Vereador municipal e morador do bairro Itapitangui em Cananeia continental

${ }^{151}$ Sindicato Dos Trabalhadores da Agricultura Familiar do Vale do Ribeira e Litoral Sul. http://www.cnpjsaopaulo.com/s/empresa/sintravale/18700372000196 Acesso em janeiro de 2017.
} 
abóbora, batata e essas mercadorias que vende na merenda escolar. Mas nós dependemos de uma licença.

E nós não conseguimos negociar porque a prefeitura não vai negociar com nós, e não vai esperar uma coisa que nem sabe se vai sair. Se não tem licença, como é que nós vamos plantar? Não tem produção. A gente teve uma proposta que se a gente tivesse a mercadoria, o caminhão era obrigatório a vim buscar. Então a gente está preso por causa disso. Eu sou titular do conselho de gestão, tanto da Resex, quanto do Parque Lagamar. Só que, o que acontece é que eles olham só o lado deles e não olha o lado dos pequenos. O conselho nosso do Lagamar, ele é um conselho consultivo, então quem tem que decidir é o poder público, né? Ele não tem interesse nenhum em ajudar a gente. Então fica tudo fechado. Mais ou menos umas vinte famílias ficaram dentro do Parque Lagamar. Só da minha família tem mais ou menos umas quinze famílias. Agora, contando o Santa Maria e Taquari, dá mais de umas quarenta pessoas. Tudo dentro do Lagamar. Eu na época, consegui licença dentro do parque, quando era Parque do Jacupiranga, o diretor era outro. Só que agora com esse diretor, a gente não conseguiu. Até o caminho dos beneficiários, do povo das comunidades, mesmo fora do parque, onde é um caminho que é da prefeitura, o parque não libera. Nem para limpar. Hoje, a gente consegue uma autorizaçãozinha, mas isso está em discussão ainda. Além do que, dentro desse parque, dentro desse caminho passa muito Jeep que estraga tudo. A gente não pode fazer nada nesse caminho, mas eles podem estragar, o jipeiro, o motoqueiro...

Eles entram ali e arregaçam, acabam com o caminho. E entram na hora que quiser. E esse caminho é usado até por criança. Teve criança que já chegou a quebrar a perna. Também teve um cavalo que quebrou a perna ali e deu trabalho para tirar porque o jeep quebrou a ponte e ele caiu de lá. E essas coisas a gente já pediu para embargar, para só a comunidade usar. Foi colocado placa e teve pessoas que jogaram a placa fora, foram colocados correntes e teve pessoas que jogaram as correntes fora. Então a gente está brigando novamente, agora que a gente tem associação. Estamos tentando fazer até uma conversa com a prefeitura e com o parque. Se eles querem liberar, então a gente cobra uma taxa dos jipeiros, para eles passarem e depois a gente arrumar os trechos que eles estragaram. Com isso você até dá serviço para o povo do lugar, porque você pega aquele dinheiro, pega oito ou dez pessoas e paga aquelas pessoas para ir arrumar os trechos. Isso é uma coisa que só a associação pode fazer. Porque a gente pediu para embargarem e eles disseram: ah, a gente não pode embargar porque o caminho fica dentro de terra particular. E se o caminho fica dentro de terra particular, nós que somos 
dono do caminho, podemos cobrar. Os jipeiros passam todos por essa estrada. Nós vemos eles passarem. Vão ter que pagar de qualquer jeito. E se a gente por uma portaria e eles não quiserem pagar, eles também não passam, porque a gente tem competência para não deixar eles passarem.

O mapa que temos daqui foi assim: aqui teve uma grilagem de terra de setenta e seis em diante. A gente teve a necessidade de chamar a prefeitura. $O$ padre João que também deu uma força para nós. E o que a gente fez? A gente entrou em briga com esses grileiros. E fomos indo... Então a SUDELPA ${ }^{152}$ entrou para fazer os levantamentos dos posseiros, e acabamos dominando as áreas. Os grileiros se renderam e saíram. Apenas em uma parte que é deles, eles ficaram, e a parte dos posseiros a gente pegou. Então, morreu muita gente. Tem muita gente enterrada em buraco por aí, que a polícia não encontrou e que foi da época da grilagem de terra. Morreu muita gente e queimaram muitas casas. Assim como tive a necessidade de queimar uma, porque os caras estavam queimando, e eu tive que queimar uma delas. Eu queimei a de um grileiro e fiquei com um terrenão que tenho aqui hoje. Mas na época, depois que a gente conseguiu aquele mapa ali, parou a grilagem de terra. Eles chegavam falando que a terra era deles, e que as pessoas que fossem arrumando a mala e saindo porque eles iam ocupar aquela área. Alguns que teimavam um pouco, eles brigavam e batiam nas pessoas. Eles tinham os capangas e jagunços. E os que eram mais teimosos, as vezes procuravam a justiça e ganhavam. Mas nessa época a justiça era muito falha, e eles ficavam mais do lado dos caras, então a gente teve muito problema.

Na época a gente se organizou em comunidades, né? A gente falou: vamos dar um basta nisso, vamos chamar a polícia e o prefeito, e vamos ver quem é responsável por isso. Porque alguém tem que ser responsável por aquela barbaridade, seja a polícia, seja a prefeitura. Isso aqui é um domínio do município, e a prefeitura que domina o município, então se existe um problema sério, alguém tem que estar por trás disso. E o prefeito estava por trás disso. O prefeito, o presidente da câmara e os vereadores, todos estavam por trás disso. E a própria polícia, né? E naquela época era difícil. A gente entrou com a SUDELPA, e o padre João deu uma força para nós também, que ele era uma autoridade

\footnotetext{
${ }^{152}$ Artigo $\mathbf{1}^{\mathbf{0}}$-Fica criada, em cumprimento ao disposto no artigo 121 da Constituição do Estado, a Superintendência do Desenvolvimento do Litoral Paulista (SUDELPA), entidade autárquica, com personalidade jurídica e patrimônio próprios, com sede e fôro na Capital. http://www.al.sp.gov.br/repositorio/legislacao/decreto.lei.complementar/1969/decreto.lei.complementar4-01.09.1969.html Acesso em janeiro de 2017
} 
e conhecia da lei. Ele já faleceu. Ele não orientava a gente, ele entrava junto. Quando era para ir no Fórum, nós íamos junto, e ele era o primeiro a estar lá, dizendo para o promotor: é isso, e tem que funcionar assim, porque esses caras são grileiros e não tem esse direito de pegar as terras das comunidades que são tradicionais”. E o padre tem força na cidade, ele era uma liderança de todo o povo, no caso. O padre João foi até em Eldorado, Sete Barras... Junto com os outros padres de lá, e junto com o bispo, a gente teve grandes encontros. Eu não lembro o nome do bispo da época. O padre João era de Cananeia, e abaixo dos bispos era ele. Ele tinha uma coordenação com os outros padres. É que não sou católico e a gente não tem bem as experiências da igreja, mas era assim. Ele era um cara ponta firme, ele foi um cara que ajudou muito o povo aqui. Independente de religião. A questão do grilo resolveu na justiça. A gente ganhou a causa. Na verdade, todas as causas que a gente teve, a gente ganhou. Eu, como era uma liderança que ajudei, em todas as audiências que tinha, eu levava o mapa para provar que realmente aquela pessoa tinha invadido.

Esse mapa foi fundamental nas brigas contra os grileiros. Foi e é, né? Porque hoje esse mapa, qualquer um que chega aí, tira foto. Até o Itesp veio aqui e tiraram cópia desse mapa, porque eles não tinham esse mapa de conflito. E foi passado um para a promotoria, um para casa paroquial e outro ficou comigo que era a liderança do bairro.

Antigamente, quando eu me casei, o meu pai trabalhava com muito camaradas. ${ }^{153}$ E nós somos da mesma comunidade do Santa Maria. Eu estudei no Paraná, e ela estudou para cá. Só que eles trabalhavam muito com o meu pai, a família dela, o pai dela, o primo dela, então a gente começou a se conhecer assim, trabalhando junto. Eu sempre tive uma ideia assim, que eu nunca fui por boniteza e nem por beleza, eu fui pelo caráter. Eles eram uma família muito trabalhadora. Então, eu estudei no Paraná, e quando o professor de lá foi transferido, o diretor e o prefeito falaram que era para ele arrumar um aluno que fosse um dos melhores, para ir dar aula no lugar dele. Então ele me nomeou e fui pra lá. Eu era solteiro. Mas nessa época que eu fui chamado, nós já namorávamos. Então o que aconteceu? O meu tio era professor, o Ailton, e ele era muito estudioso e nós tínhamos a mesma nota. Era eu, ele e minha irmã, a gente era sempre a mesma nota: noventa, cem... Era só nota boa. Ele nomeou nós dois. E ele falou: Carlinhos, se você não quiser, a gente vai colocar o Ailton. Só que lá tinha uma turma meio racista e não gostavam dele porque ele era preto. Então todo mundo queria que eu ficasse.

\footnotetext{
${ }^{153}$ Forma de se referir aos trabalhadores contratados que não fazem parte do núcleo familiar.
} 
Tinha muito preconceito. Você vê que hoje tem uma comunidade registrado quilombola, lá! Então, eu fui lá e conversei. E esse meu tio tinha uma fazendinha, ele tinha um gado no terreiro, ele tinha três roças de mandioca, duas roças de feijão, duas roças de milho e duas roças de arroz. E ele me deu tudo. Eu ia entrar com tudo feito. Ele me deu tudo os gados dele, galinha e uma casa de farinha e tudo. Mas, eu ia para lá sozinho? Foi a hora que fui lá e falei para o pai dela: olha, eu namoro com a sua filha e estou indo lá para o Paraná, e é meio difícil para onde eu vou. Eu queria ter uma companheira para me ajudar lá, porque eu vou dar aula e vou ficar sem ninguém em casa para cuidar das coisas. Ele falou: se você acha que ela quer ir junto, e ela quiser ir. Ela estava doidinha para ir! Então fomos. E a família dela ajudou a levar as coisas dela, e nos amigamos ${ }^{154}$ numa boa. Ficamos seis anos amigados. Então ela queria batizar na igreja, e nós casamos. Entre amigado e casado são quase trinta e oito anos. Ela tinha 19 e eu tinha 21. Ficamos por lá uns três anos mais ou menos. Aí, eu desisti de dar aula para a turma. Foi na época que surgiu uma vaga e os meus primos me chamaram para trabalhar no Hotel Glória. Acertamos tudo lá com o meu tio, vendi a minha parte de gado, cavalo e essas coisas que eu tinha, e vim embora. Fui para a cidade e morei lá uns tempos uns cinco anos, não deu certo e voltei para o sítio. A minha vida mesmo foi o sítio. Meus filhos Nei e Valdina nasceram aqui, e Néia e Célia nasceram na cidade. Eu tenho cinco filhos e dezesseis netos. O nome eu não lembro, só lembro da idade. Os meus filhos foram criados tudo aqui. Quem saiu, saiu com 20, saiu com 25, saiu com 22. Só a Néia que saiu com 15 anos. Nessa época eu trabalhava com um senhor lá da cidade. Eu morava aqui e trabalhava para ele, que tinha um sítio e tinha o barco. Ele tinha também uma fábrica de palmito, e, uma vez por semana eu ia para o Paraná para trazer palmito para cá. Eu fazia uma viagem por semana. E às vezes pegava aqui da turma e levava também. Eu trabalhava com barco, e a esposa dele queria que eu mandasse ela para lá, para estudar e trabalhar com ela. Então mandei, porque na época aqui era difícil a escola. Aqui era só até o quarto ano, só o primário. Se não fosse para a cidade, não estudava.

Naquele tempo não tinha ônibus e nem estrada. Os professores que vinham para cá, eles andavam junto com a gente nas canoas. Eles iam de mês em mês na cidade. Quando tinha reunião ou alguma coisa, a gente levava eles de canoa. Os outros filhos eles saíram para trabalhar porque aqui ficou ruim, ficou sem serviço. Quando a gente

\footnotetext{
${ }^{154}$ Casamento não institucionalizado.
} 
trabalhava na feira, que tinha bastante lavoura, a gente podia levar para a cidade, tinha serviço para eles. Mas a partir da hora que paramos de trabalhar, acabou o serviço. Você vai manter uma família como no caso deles que querem ter a própria vida? Como é que eles podem ter a vida deles aqui? Eu é porque a minha mulher é aposentada e eu já sou aposentado, então dá para a gente viver. E meus filhos? Um filho casado e sem salário, ele vai viver do quê? Ele não pode plantar, não pode colher e não ter serviço para trabalhar todo dia. Hoje, um filho meu é açougueiro, uma filha também é açougueira e a outra casou e o marido faleceu, então ela recebe a aposentadoria do marido, e é casada com outro rapaz.

A mãe da Bia ${ }^{155}$ é açougueira. E teve um outro rapaz que ele teve sorte de pegar um serviço numa fazenda aqui, e cuida da fazenda. E não tem outra opção. Ou você fica de caseiro, ou você não trabalha. Não tem serviço aqui. É igual serviço para mulher. Quando a gente plantava roça, tinha serviço para mulher. A mulher ia fazer farinha para levar para a feira, ia fazer o biju... E eles também faziam junto. Pai, eu vou na feira amanhã, você quer que leve alguma coisa? Então, eles levavam bastante coisa. Tinha serviço. Agora, não. Agora acabou a feira, e nós não temos licença, não temos roça, e aí tem que ficar em casa. E o que acontece? O marido vai para um lado, ela sai para outro, e é difícil. A molecada daqui, eles foram embora. E se você chegar em Cananeia no supermercado e perguntar quantas pessoas daqui trabalham lá... Se você chegar no supermercado Milênio, quantas pessoas daqui trabalham lá? No mercado Takaji e em tudo que é mercado você encontra gente daqui. Nas diversas pousadas tem pessoas daqui que trabalham lá.

Eles só saíram daqui porque não tem condições de viver. Na época que todo mundo vivia aqui, fazia roça e trabalhava, tinha mutirão e tinha diversão. Todo sábado a gente fazia aqueles mutirões comunitários, sabe? Hoje a gente vai para um, amanhã a gente vai para outro, e outro dia você vai para outro. Era uma maravilha, todo mundo trabalhava em conjunto, e era gostoso de você trabalhar. Assim, no caso você ia plantar a mandioca. Os homens limpavam a roça e queimavam. Tinha um pouco que ia cavar, tinha um pouco que cortava ramo, tinha outro pouco que plantava. E nesse dia a gente ia para uma pessoa, e no outro dia a gente ia para outra pessoa. Cada um fazia o seu serviço. E quando não era roça de mandioca, era roça de arroz ou era roça de milho. Ou era para fazer uma canoa. Os homens se ajuntavam e iam fazer uma canoa e as mulheres

\footnotetext{
${ }^{155}$ Neta que mora junto com o casal no sítio.
} 
iam fazer outra coisa. Mas sempre tinha serviço, todo mundo tinha uma ocupação. E hoje, não. Hoje, se você sair daqui, você vê todo mundo em casa. Nós temos quatro pessoas aqui empregadas, são quatro caseiros.

Tem cinco sítios. Tem do Adalmir, do seu Antônio, do seu Zé... São cinco famílias que trabalham empregados como caseiro. Eu acho que se tivesse serviço mais gente tinha ficado. Aqui era uma diversão e ninguém iria embora se tivesse condições de viver aqui. Depois do serviço a gente fazia um forrozinho ou ia brincar de bola. A gente saía muito para jogar bola nos outros lugares. Dia de sábado à tarde, a gente juntava as turminhas e ia para Rio Verde, ia para Serra Negra, Cananeia ou Jacupiranga.

Ivone - Quando dava a gente ia junto.

Carlos - Eu sempre tive um problema assim: eu sempre gostei de carregar a minha família junto comigo. É bom porque conhece. Além de você estar com um companheiro ou uma companheira, as pessoas conhecem o lugar e fazem amizades com pessoas diferentes.

Ivone - E eu vou, e a gente fica conversando.

Carlos - A gente não teve desentendimento por isso. A gente teve desentendimento por causa da crianças e tal, mas negócio de ciúme, de briga, não. Ela já foi para São Paulo com a Igreja dela, vai para Registro... Também tem os grupos de mulher que eles não deixam a gente ir.

Ivone - Os homens não podem ir. Os homens ficam chatos lá no meio! A gente chega nos salões, tomamos um café e cada uma vai fazer a sua atividade. Faz bordado e vende. A gente vai para Itapitangui, Porto Cubatão... Esse bordado aqui está tudo misturado. É que lá, a gente fica cada um numa sala. Numa sala fica eu e a Nézinha, e outros grupos ficam em outra sala. Suponhamos que tem dez comunidades e formam cinco grupos. Então vai uma do Taquari, vai uma do Mandira, outra de Eldorado, de Itapitangui... E juntando um de cada grupo, eles fazem outro grupo. É que também uma dá ideia para a outra, né? E aí vai saindo.

Carlos - É para se conhecerem e fazer um trabalho diferenciado, né?

Ivone - Apileiras, é essa tintura aqui. É isso aqui. Você vai explicando onde é a escola, onde é a estrada...Você faz uma carta e vai explicando onde fica tudo o que tem no município, o que você precisa, condução, saúde e tudo. Aí você entrega a carta e vai para lá. E cada grupo fica com um desses. Esse aqui a gente vai deixar lá na sede da associação. 
Carlos - É, a gente vai deixar. O único problema é que eu falhei em não guardar todos os arquivos das minhas demandas, de tudo o que já foi feito para mostrar na sede da associação. Quando nós trabalhamos com a feira, esse meu rancho de farinha era bem feito, mas eu vou reestruturar ele novamente para deixar como modelo.

Ivone - A farinha era eu... Tinha o pilão para socar a massa. Era o que mais vendia.

Carlos- Então, mas é o que eu falo, nós não temos essa coisa de ciúme assim, para sair. É o nosso trabalho, e se eu trabalho com a comunidade, eu não posso ter ciúme da minha mulher. Porque, se eu saio daqui e vou a um encontro, e vem uma pessoa, a minha mulher vai ter que receber aquela pessoa. Teve o Guilherme que veio aqui sábado...

Ivone- É, que você foi levar um papel na associação.

Carlos- Então, ele ficou. Porque essas pessoas são assim, eles mandam para cá, e a comunidade recebe, e a aquela pessoa vai ter que fazer tudo aquilo que a gente faz. Está aprendendo. É um estagiário, e veio para viver a vida que nós vivemos. Ele veio e queria fazer uma coisa, queria fazer outra, mas a gente dava uma maneirada, né? Nós recebemos bastante gente aqui. O pessoal que faz pesquisa se informa lá em Cananeia e perguntam quem é fulano e tal. O nosso trabalho foi muito divulgado na época que a gente trabalhava com turismo. E foi bem bonito. Nós chegamos a receber até grupo da França e da Alemanha. Começou a vir grupo de escola para gente fazer uma palestra com eles. Eu fiz diversas palestras e fui chamado nas escolas para contar as histórias do bairro, do cemitério e de como que era o Santa Maria.

Eu contava que Cananeia é a segunda cidade e o segundo povoado do Brasil. Ela tinha briga com São Vicente, mas o primeiro povoado era no Porto Seguro da Bahia, onde Pedro Alvares Cabral aportou. Foi onde eles entraram em terra firme e deram o nome de Vera Cruz. Depois mudaram para Terra de Santa Cruz. Então depois começaram a andar no mato e começaram a ver madeira vermelha, e começou a briga. Então madeira vermelha do Pau Brasil é porque eles viram muita madeira vermelha no mato, e confundiram com brasa. E resolveram colocar Brasil por causa da madeira vermelha. É só o Pau Brasil que é vermelho. E por causa disso que o nome é Brasil. E Cananeia foi o segundo porto quando descobriram o Brasil, onde eles encontraram um lugar para encostar o barco e acharam um abrigo. Eles colocaram ali o nome de Bom Abrigo. E o Bom Abrigo hoje fica em Cananeia. Eles entraram e viram aquele mar pequeno, e foi onde eles começaram a colonizar, foi a segunda colonização do Brasil. E o primeiro povoado foi em Santa Maria. 
Eles começaram a colonizar e trazer fazendeiro no que hoje é Santa Maria, Mandira e Ilha do Cardoso onde fica aquelas casas de pedra, onde eram guardados os escravos. E encostava um vapor, entrava um barco em Cananeia e pegava produto para levar para o porto de Santos. Então tinha aquele transporte de Cananeia para Santos, levando a mercadoria. Cananeia era o que vendia mais arroz, farinha e feijão. E a nossa região era uma colônia muito agrícola, só dava agricultor. O meu avô era um desses agricultores. E o meu avô tinha um engenho de pinga e um engenho de arroz. $O$ rio que corta o nosso sitio, ele é rio de engenho, porque ele era o rio que jogava água para girar o engenho do velho.

Aqui teve imigração de diversas famílias, teve dos europeus, dos franceses, dos ingleses, dos portugueses... Esse povo, eles entraram junto colonizando o Brasil, e encontrando índio, né? Porque a história que eu lembro é que em Cananeia tinha muita cana, e os índios plantavam muita cana. E existia uma ilha com o nome de Néia. Então eles fizeram Cana e Néia, e foi Cananeia. É igual o rio Taquari, que é por onde os índios puxavam as taquaras para fazer os trabalhos deles. Aqui tem muita taquara. O povo de Cananeia quando fazia o cerco, comprava muita taquara daqui.

Daqui para lá era Taquari, e dali para cima era Santa Maria. Virou tudo Santa Maria porque, quando começou essa grilagem de terra, lá no Taquari só dava grileiro, então o povo queria passar tudo para Santa Maria. E a igrejinha lá em baixo, a Santa é a Maria, então a gente aceitou eles entrarem com o nome. Ali, do rio para baixo, era Santa Maria de baixo. Mas virou tudo Santa Maria. Esse rio é o Taquari. O rio Branco sai da colônia de Santa Maria e desagua no Taquari. O rio vermelho sai aqui do sítio e deságua no Taquari. E tem o rio Pequeno que sai do faxinal e deságua também no Taquari. Faxina é assim: aqui tem uma área de terra que é tudo morrinho baixo, e quando se fala em morro baixo, é faxinal. E a turma colocou o nome de faxinal, mas chamam de faxina. É uma área aqui, que tem só mamotos. Mamotos são morrinhos pequenos. A faxina são aqueles morrinhos pequenos que ficam na encosta de uma serrinha. Tem uma serrinha que chama morro alto, e depois tem a serra grande. Aqui tem a serrinha, tem a serra do rio das Minas e tem a Serra do Gigante, que é a serra do município. Nessa época que Cananeia começou a se desenvolver não tinha ligação assim por terra entre São Paulo, Rio de Janeiro, Paraná, Rio Grande e Mato Grosso do Sul. A ligação deles era só por água. Então eles resolveram fazer a linha do telégrafo que é a linha do Imperador. E é onde eles tinham os caras que carregavam a carga, os telegramas. É por causa disso que se chama linha do telégrafo. Essa linha tinha fio, e de 
cem em cem metros ela tem um poste. E era bem limpa para o povo não se perder. Então, de Cananeia tinha um posto, aqui no Mandira ${ }^{156}$ tinha outro, aqui na divisa de Batuva ${ }^{157}$ tinha outro... Cada trecho, um trazia dali, e esse entregava para outro e fazia aquela formiguinha. E o cemitério foi porque veio a família Klink, e era uma fazenda bem organizada.

Tinha luz, transformador, motor e tudo. E um dia faleceu o filho de um Klimke, dos alemães, e eles queriam enterrar perto de casa. Eles foram e pediram autorização na prefeitura dizendo que eles queriam fazer um cemitério. E que eles davam um pedaço de terra para fazer um cemitério para que o povo de Santa Maria fosse enterrado ali. Naquela época não tinha tanta burocracia. E ninguém queria ficar naquelas gavetinhas bonitinhas e bem azulejadas. Aqui depois de morto, a pessoa era carregada em canoa. $O$ cara era carregado no pau. A gente chama de rede. Então foi autorizado e foi feito um cemitério, e eles enterraram o primeiro filho deles ali. E quando falecia uma pessoa, a gente chamava um carpinteiro e sempre era o meu tio que fazia os caixões tudo de madeirinha bem feito, e a gente enterrava aqui mesmo. E hoje tem o cemitério, mas como começou a morrer muita gente, hoje eles pedem para levar para autopsia. Então foi proibido de enterrar aqui, e tem que levar para Cananeia.

Então, essa história do Santa Maria foi assim. Foi crescendo e virou uma colônia agrícola. A minha família, eles fazem parte da história do Santa Maria. Eu sou dos Franças e do Xavier. Os Xavier foram um dos fundadores do Brasil. Tem ligação com os Xavier do Itapanhapima. Eles são meus primos lá. O Rodrigo, a turma do Cardoso também.... Tudo primo. Primeiro terceiro, quarto, mas tudo tem ligação.

Eu sou França Xavier Paiva. E sou da Silva. A minha bisavó era Xavier Paiva, e o meu bisavô era França. Ele casou com uma brasileira. Era aqui da região mesmo. Henrique França. E também casado com uma Xavier da Prainha. Sabe onde é a Prainha? É aquela que tem a família de Leonildo, de Chiquinho, Joaozinho...Mas eles tudo saíram daqui da região, mesmo. Desde a fundação da cidade, a família da gente já estava envolvida. De um lado eu sou de quarta, e do outro sou de quinta e sexta geração. Do Henrique veio o meu pai Jeremias França, casado com a minha mãe Xavier Paiva. Eles eram primos segundos. Nós dois somos primos de quarta geração. O seu avô era primo do meu avô. E a gente tem o sangue, né? Veja bem, no caso, o meu bisavô tinha uma fazenda que era aquela que mostrei no mapa, a fazenda Rio Branco. Era Lima Silva França e quando ele

\footnotetext{
156 Quilombo do Mandira, reserva extrativista em Cananeia continental.

${ }^{157}$ Bairro de Guaraqueçaba no Paraná
} 
faleceu ficou para o Henrique França. O Henrique França morava aqui embaixo, e eles fizeram uma capuava lá em cima. Capuava é aonde você vai num lugar e faz um barraco e planta. Então, ele fez um barraco só, e quando ele foi para lá, ele fez uma roça, que dentro dessa roça tinha uma pedra grande, eram duas pedras. Então, ele era um cara de coragem e novo, e ia formar a vida dele lá, para levar mulher dele pra lá. Aí, ele cercou de pau a pique tudo em volta. Pau a pique você finca ela e amarra as varas de atravessado para segurar. Ele fez um painel de milho e dormia em cima do painel do milho e, do lado, ele fez um puxadinho para fazer o fogo. E morou três anos embaixo dessa pedra. E quando levou a mulher para lá, ele fez casa.

Na época, a vida do povo era acampar. A gente chama de rancho capuava... Nós também tínhamos capuava. Moramos aqui, mas a gente ia trabalhar lá nos fundos e, como é longe para você ficar indo e voltando, você monta um rancho lá. Passa uns dias, trabalha e volta. Cada coisa dá para plantar num lugar. E a capuava era por causa disso. Às vezes você tinha uma ou duas capuavas. Nós temos uma capuava em lagoa grande, e outra lá no rio de engenho. Na Lagoa Grande dá feijão, milho, arroz, banana... E para cá já dá mandioca, feijão... Para cá da tudo, né? E aqui para cá tem uma diferença porque tem muita saporema. Saporema é uma coisa que dá na raiz da planta e acaba matando. Apodrece a mandioca. Eu acredito que é acidez, muita acidez. Ela cria aquelas bolas de ferrugem. A gente chama de doença de saporema. Nossa terra aqui tem muita acidez. E precisa queimar porque quando você queima, ela já mata a acidez. A gente tem o costume de queimar e já plantar em cima, e aquela planta pega toda a cinza que também é adubo. Assim corrige a acidez. Então, o nosso problema é isso. A nossa maneira de trabalhar é essa. Agora, se os técnicos da prefeitura ou do IBAMA viessem explicar para nós e dar condição para a gente trabalhar, você tem condições de mudar a maneira de trabalhar também. Se eles limpam um alqueire de terra para gente, você pode até fazer um adubo mais leve que é o adubo verde, e que você pode usar como adubo orgânico. Só que não existe essa possiblidade de fazer isso ainda, porque o poder executivo é pouco, e a gente não tem como comprar uma máquina, como comprar um arado. Voltando na história do Santa Maria, foi assim. Essas famílias foram crescendo. Depois teve a história da primeira guerra mundial em que vieram muitos imigrantes. Eles compraram terras não só do governo, mas de firmas de colonização. E foi formando essa colônia. Eles criavam gado e todo sábado eles matavam um boi. Era para vender. E também fazia para festa, porque tinha festa de Santo Antônio, São Pedro, São João... Cada um dava um pouco de mercadoria, e fazia a festa. Dançava a quadrilha, e depois da quadrilha era o 
forró até de manhã. E ali quem era casado era casado, e quem não era casado, às vezes arrumava casamento!

A família Klimke fez parte da colônia também. Tinha a colônia agrícola de Santa Maria, e depois foi feito a colônia Novo Núcleo, que foi a terceira colônia. Tinha bastante gente. Eles trabalhavam, produziam bastante e vendiam na cidade. Um dos maiores eram os Klimke e os França. Os França era porque o meu avô tinha o engenho. Hoje acabou tudo e não tem mais nada. Em sessenta e oito teve esse projeto de lei do Parque Jacupiranga, que foi quando foram proibindo o povo. Meu pai era vivo e eu tinha 14 anos quando surgiu o parque. Foi difícil. Veio uma turma do estado falaram que ia fazer um levantamento da terra para fazer uma pesquisa e tal. E quando o povo viu, já era parque. Eles não vieram conversar com o povo: Ah, o estado vai indenizar vocês e vai fazer um parque aqui, porque isso tem um projeto de lei e tal. Não. Eles chegaram medindo, parando na casa das pessoas e mentindo para as pessoas. Dizendo que o estado estava fazendo um levantamento das terras, que tinha uns projetos para a melhoria do município e tal. E o povo não foi se informar. Eu com 14 anos chamei o meu avô, meu pai e dois tios e falei: se eu fosse vocês, eu não aceitava essa medição. Eu ia lá na prefeitura ou em algum lugar ver se realmente isso é uma medição que vai favorecer vocês ou se vai prejudicar. E o meu avô era uma pessoa que confiava: ah, isso aí é um levantamento, é o governo que está medindo. E mentiu para o povo. Isso aí é um parque da traição. E na verdade, não somos nós que estamos roubando o governo, é o governo que está nos roubando, porque não indenizou ninguém e não pagou ninguém. E isso é uma tradição nossa, nós temos as escrituras dos terrenos. Então a história de Santa Maria é assim. E depois o pessoal foi saindo, foi saindo... Prejudicou muito a agricultura, e nós estamos desse jeito. Poucas pessoas e sem poder trabalhar. Quando foi virar Lagamar nós tivemos uma audiência pública em Cananeia. O prefeito chamou para dizer para o parque qual eram os nossos direitos e que eles tinham que respeitar, só que eles não respeitam. O prefeito falou: eu só assino nessa condição, porque vocês têm que respeitar o direito das comunidades tradicionais e tal. Nessa época a gente formou o Conselho de Desenvolvimento Rural, o CMDR. Ali a gente tinha muitas discussões boas. Nós queríamos voltar a estruturar esse conselho, nossas reuniões eram bimestrais.

O prefeito era José Carneiro Filho. Conhecido como Gera. Mas quando eles vieram, eu até estava no campo jogando bola, o rapaz chegou conversando e queria fazer o levantamento. E no papel estava que, era 500 metros para lá, e 500 metros para cá da 
estrada. Eu conversei com ele e não aceitei. O rapaz era o Ocimar ${ }^{158}$. Falei que era muito pouco, que tinha que ser na base de 1.500, e para lá pedi dois mil e poucos metros. Aí ele concordou.

A medida começa na escolinha. Da escolinha é 500 metros para cá, e seguindo a reta são 1.300 metros. Se fosse desenhar seria uma tripinha com a estrada no meio. Para cá uma parte maior, para lá uma parte pequena, menor. E aqui embaixo encostaria nos dois rios, o Taquari e Carapara. A reserva vem da barra do Taquari e pega aqui na divisa do bairro Rio das minas, junto com o Mandira. Passou da RESEX do Mandira, já é RESEX Taquari. Tanto a RESEX como a RDS começam no Rio das minas. Aí tem Carapara, Guapara, Canta Galo, o rio continente, Ilha da Casca, Bom Bicho, Retiro... Até a reserva do Tumba ${ }^{159}$.

Nós estamos entre esses dois rios, o Taquari e o Carapara. Nós usamos esses dois rios. E também temos 200 metros do mar para dentro e depois vira área particular. $O$ desenho da RESEX vem da estrada de Santa Maria, passa a estrada do Ariri. Imagine que aqui é a estrada, aqui é o rio taquari e aqui é o rio Carapara. E aqui é o mar. Esse rio Taquari deságua aqui no mar. E esse Carapara entra na RESEX e vai para o mar também. Então, esse meio ficou fora do parque, para nós. Daqui de casa, dois mil e poucos metros para lá, já é o parque do Lagamar. E subindo o rio Carapara da estrada para cima, daqui é mil e trezentos metros. Esse Carapara, o Lagamar começa nele, o parque encosta nele. É dois mil para cá, e mil e trezentos para lá. É entre a estrada e o sítio. O rio é neutro, não tem parque, só lá embaixo que é a saída entra na RESEX. A divisa do Carapara seguindo o Rio e depois a divisa é no Alfredo Sens, dono de muitas terras por aqui.

Então do Carapara para cá é Lagamar e para lá é fora do parque. Tem a casa do Silvio Zafaroni entrando no Taquari. Na estrada do Ariri, a primeira casa ali no morrinho tem um riozinho... aquele é o Carapara e dali para frente já é parque. Ele é Lagamar até encontrar a RESEX. Antes de chegar no mar fica os duzentos metros da Resex. Então, ele é parque quase inteiro. Só é liberado a nossa parte. É fácil de você entender pelo mar. Ali você pega a linha do mar que vai para o Ariri. Onde termina o mangue, os duzentos metros, é a RDS do Itapanhapima. E o que sobra é o Lagamar, que é onde o Gentil briga para poder plantar ali. É um pedacinho só, e o resto tudo é do Lagamar. Então, a gente negociou essa linha do Lagamar porque a área da RDS não

\footnotetext{
158 Ocimar Bim é funcionário da Fundação Florestal.

${ }^{159}$ Reserva Extrativista da Ilha do Tumba, também em Cananeia Continental.
} 
estava incluída. A gente negociou daqui até o Ariri. A gente tirou cinquenta metros na lateral da estrada, para manutenção da estrada do Ariri. E o resto é parque. E foi tirado também a parte dos moradores tradicionais que tinham as suas posses ou as suas escrituras, que então foi feito o núcleo de moradores. Ficou pouca gente na RESEX porque o povo não mora na beira do mar. É o que eles não entendem. Esses sítios todos são na beira do mar, mas ninguém mora na beira do mar.

Ivone- Vão para pescar.

Carlos- Então como o lado de cá ficou Lagamar, e o lado de lá ficou RESEX, ninguém fica dentro da RESEX. Só que usa aquela área, que é onde às vezes eles querem impor uma lei de que não podemos usar. É igual o nosso sítio aqui, todo mundo aqui usa o rio para ir para o mar, é o nosso caminho da cidade. Se acontece alguma coisa na estrada, nosso caminho é o mar. A RDS é onde tem mais morador e a RESEX porque os moradores moram retirados é um caminho de uso comum e área de passagem da turma. Ali é um caminho de uso constante, né? Para pesca, para viagem à Cananeia... A gente usa os dois rios, Taquari e Carapara, mas não moramos ali, é para pesca e acesso. 


\subsection{Reserva Extrativista Taquari}

Rio Taquari ( Hidrografía )

Estado: São Paulo Municipio: Cananéia Distrito: Cananéia

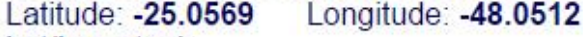

Lat/Lon atual:

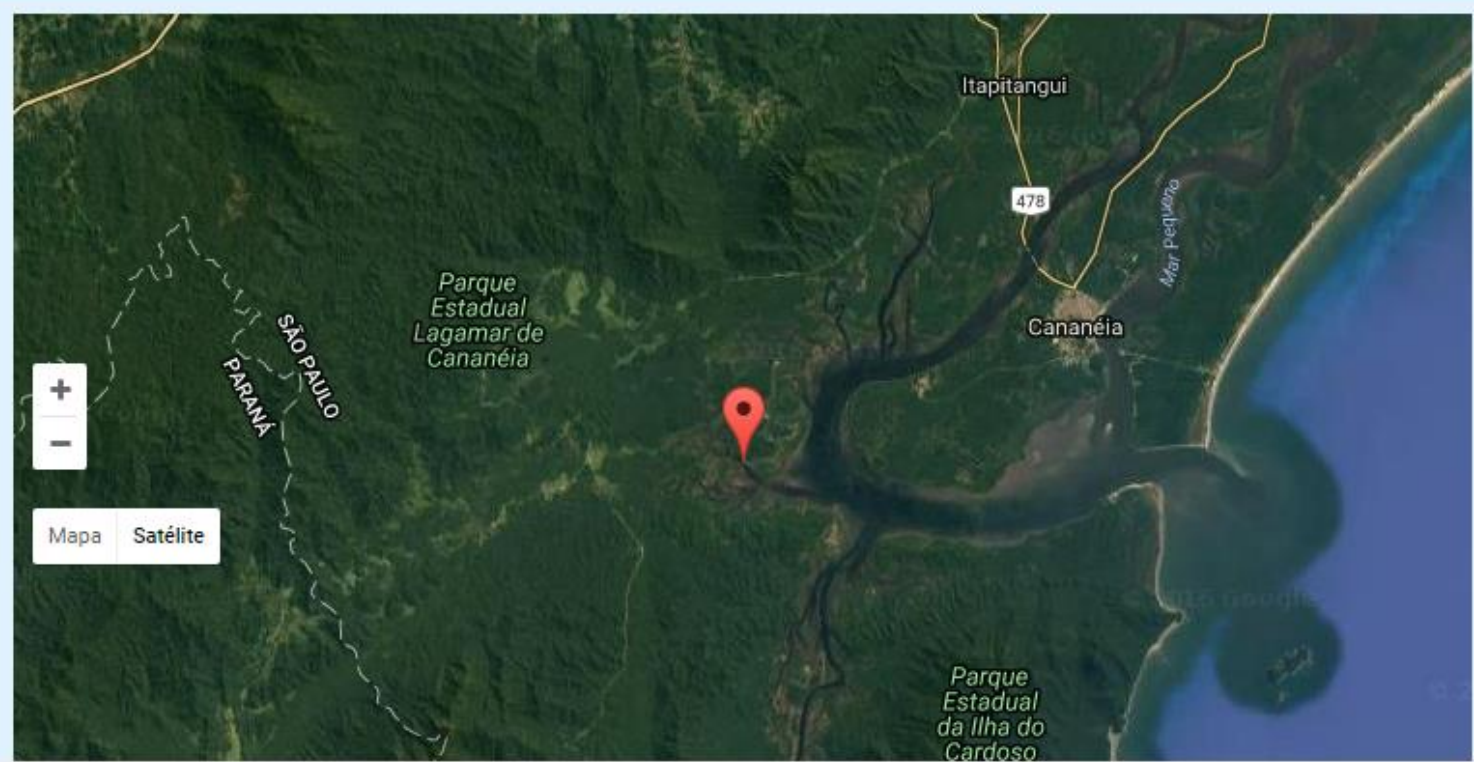

Fonte: http://mapasamerica.dices.net/brasil/portugues/mapa.php?nombre=Rio-Taquari\&id=105048

A narrativa de Carlos França e Ivone França, assim como a de Noêmia, apresenta muitos dos aspectos ligados a sua historicidade no território, de forma a enfatizar características que reforçam seus direitos vinculados à condição de população tradicional. Como Noêmia ele associa a criação do parque às interdições das práticas culturais, sobretudo vinculadas à agricultura como fator que inviabiliza a permanência na área rural. Sua crítica ao desrespeito com que as políticas púbicas tratam os direitos das populações tradicionais, aproxima-se também da de Noêmia no que se refere à associação desse desrespeito ao não desenvolvimento econômico e social da área. Isso teria consequência sobre os muitos aspectos da permanência, sobretudo no que se refere aos jovens. Segundo ele, as interdições legislativas da área impedem que as antigas práticas econômicas sejam realizadas, sendo responsáveis pela obrigatoriedade da busca por trabalhos assalariados. Além da escassez de ofertas assalariadas na região, os pouco trabalhos são direcionados aos homens. Nesse sentido, a criação de atividades produtivas, como a roça e o beneficiamento desses produtos, como a farinha, poderia gerar renda para a inserção de jovens e de mulheres. Noêmia enfatiza ainda ser necessário implementar escolas na área, 
permitindo que esses jovens possam terminar o ensino médio sem abandonar o vínculo com o território e que essas poderiam ser voltadas para o desenvolvimento dos potenciais econômicos específicos da região. A escola estadual que existe no bairro pertence à Diretoria de Ensino de Registro e possui uma única sala de aula, multiseriada de $1^{\circ}$ ao $5^{\circ}$ ano do ensino fundamental. A partir do $6^{\circ}$ ano os alunos precisam se deslocar para a escola de Porto Cubatão que fica próxima à área urbana de Cananeia. Dessa forma, alunos como a Bia, neta de Carlos e Ivone França, precisam sair de casa ainda pela manhã, retornando apenas à noite. A manutenção da estrada é um fator determinante para garantir o acesso dos alunos à escola, sendo frequente os períodos em que o ônibus não consegue chegar até o bairro ${ }^{160}$.

Carlos e Ivone são moradores da Colônia Santa Maria, cujo acesso se dá por uma estrada vicinal adjacente à estrada Itapitangui Ariri no seu lado voltado para a serra. A Colônia de Santa Maria foi fundada em 1915, ${ }^{161}$ sobretudo por imigrantes alemães e austríacos. No entanto as áreas próximas já eram habitadas por franceses como o bisavô de Carlos França, Lino da Silva França, que comprou um título de posse em 1860 onde já havia um engenho de arroz. Também como parte desse mosaico cultural, as áreas próximas à colônia eram habitadas por famílias de remanescentes de quilombos como os Pedro, os Garcias (como Noêmia), os Paulas, os Fundador e os Amaro ${ }^{162}$. Além disso, o bairro também mantém a interação com regiões de fronteira com o Estado do Paraná, como o bairro Batuva. As áreas das famílias dessa região enfrentaram nos anos de 1980 um intenso processo de invasão por grileiros, sendo o advogado Manoel da Silva Lisboa um dos responsáveis por tal ação, segundo Carlos França. O principal episódio narrado, tanto por Carlos quanto por Noêmia, em relação aos conflitos fundiários vivenciados na área refere-se à tentativa de grilagem das terras da família Paulas. Após a vitória no processo judicial que contou com o auxílio do Padre João 30 e a liderança local de Carlos França, a SUDELPA regularizou a área com a emissão de títulos e a criação de um mapa

\footnotetext{
${ }^{160}$ No mês de abril de 2017, os moradores do Santa Maria e do Taquari fizeram um protesto na Câmara Municipal da cidade exigindo melhoras na estrada, dada a impossibilidade dos alunos frequentarem a escola.

http://noticiasdecananeia.com.br/noticia/366/protesto-acaba-em-tumulto-em-frente-a-prefeitura-decananeia-virando-caso-de-policia- Acesso em janeiro/2017

http://g1.globo.com/sp/santos-regiao/noticia/moradores-de-cananeia-sp-fazem-protesto-por-melhorias-noacesso-ao-bairro-ariri.ghtml Acesso em janeiro/2017

${ }^{161}$ MOURÃO, op. cit.p.46.

${ }^{162}$ MAGDALENA, Bianca Cruz. Reza a Lenda. A Cultura Caiçara de Cananeia vivenciada no Bairro Rural de Santa Maria. Londrina: Idealiza Gráfica e Editora, 2008.
} 
oficial que reconhece essa titulação. Segundo Carlos França, foi nesse momento de luta contra os invasores que a ideia de organização comunitária se desenvolveu.

Em relação à sobreposição das unidades de conservação, a área da Colônia Santa Maria foi diretamente afetada pela criação do Parque Estadual do Jacupiranga em 1969, que incorporou as terras de diversas famílias, inclusive a de Carlos França. Em decorrência de sua militância em prol da organização da comunidade do bairro, ele atuou diretamente no processo de criação do Mosaico de Unidades do Jacupiranga (MOJAC) em 2008, fazendo parte da comissão que questionou a forma como o Mosaico foi concebido e negociando os novos limites territoriais. Talvez por essa relação política com a questão, ele define mais claramente as categorias de unidades de conservação, utilizando sobretudo os termos "parque" referindo-se ao Parque Estadual do Jacupiranga, que foi reclassificado categoricamente, e ao Parque Estadual Lagamar, criado com a implantação do MOJAC e RESEX para a área de uso da qual é beneficiário. Segundo Carlos, a área do bairro ficou cercada pelo Parque Estadual do Lagamar na área dos fundos do bairro voltado para a serra, ou "sertão", e pela RESEX Taquari nas áreas de uso voltadas para o estuário marítimo lagunar. Apesar de insatisfeito com a demarcação, ele destaca que o projeto inicial do MOJAC que foi renegociado era ainda pior, posto que incluía muitas áreas ocupadas no Parque Estadual Lagamar. Tal configuração desfavorável às populações que habitam a região (e não apenas a área do bairro) pode ser melhor compreendida pelo processo de construção do Mosaico de Unidades de Conservação.

Segundo o trabalho de pesquisa de Ocimar $\operatorname{Bim}^{163}$, um dos primeiros realizados sobre o processo de construção do MOJAC, ele foi criado sobretudo voltado para as demandas da região do Médio Ribeira, onde se concentra grande parte do território do Parque Estadual do Jacupiranga e dos bairros rurais a que ele se sobrepôs. O primeiro projeto de lei elaborado para ser apresentado à Assembleia Legislativa do Estado de São Paulo (ALESP) em 2003, previa a exclusão de diversas áreas nas cidades de Barra do Turvo (22 bairros), Cajati (7 bairros), Eldorado (4 bairros) e Cananeia (4 bairros). Todas elas deveriam ser transformadas em unidades de conservação sustentáveis. Em Cananeia, apenas o bairro Colônia de Santa Maria que hoje integra o grupo de pessoas beneficiadas

\footnotetext{
${ }^{163}$ Geógrafo e técnico do Instituto Florestal, órgão ligado à secretaria Estadual do Meio Ambiente de São Paulo, Ocimar Bim atuou como representante do Estado durante o processo de construção do MOJAC. BIM, Ocimar. Mosaico do Jacupiranga - Vale do Ribeira, São Paulo: conservação, conflitos e soluções socioambientais, FFLCH, São Paulo, 2012.
} 
pela RESEX Taquari foi citado como parte a ser excluída do Parque Estadual do Jacupiranga. Esse primeiro projeto foi aprovado na ALESP em 2003, mas vetado pelo então governador Geraldo Alckmin. No entanto, o veto encontrou resistência por parte dos grupos já mobilizados pela possibilidade de serem excluídos do Parque Estadual que tanto os oprimia. Ainda segundo Bim, tal mobilização obrigou o governador a recuar e, em 2005, criar por meio de decreto ${ }^{164}$ o Grupo de Trabalho Intersecretarial do Parque Estadual do Jacupiranga, (GT- PEJ) ${ }^{165}$.

A ampliação da participação de diversos grupos da sociedade promoveu debates que culminaram com a criação de um corpo de princípios norteadores do novo projeto a ser reelaborado para o MOJAC. Dentre esses princípios, destacamos dois especialmente relevantes para a compreensão da ampliação de áreas inseridas no MOJAC na cidade de Cananeia e a criação das RESEX Taquari e RDS Itapanhapima:

- Seria necessário rever os limites do PEJ e retirar as áreas de populações tradicionais e de outras ocupações já consolidadas.

- Como compensação, seriam incluídas outras áreas de remanescentes florestais ou estratégicas para a conservação.

Outras questões fundamentais para a construção da problemática da criação dessas unidades de conservação em Cananeia é a reafirmação de que o Mosaico de Unidades de Conservação contemplaria diversos espaços com diferentes categorias de uso e manejo. Além disso, a proposta deveria ser elaborada com a efetiva participação de todos os segmentos envolvidos. ${ }^{166}$

De acordo com as discussões e deliberações realizadas pelo GT- PEJ ${ }^{167}$, foram identificadas extensas áreas localizadas na parte continental do munícipio de Cananeia que apresentavam contínuos muitos bem preservados de Mata Atlântica. Devido a essas características, poderiam ser incorporados como unidades de proteção integral ao MOJAC, cumprindo a ideia de compensação ambiental. Dessa forma, surgiu a proposta do Parque Estadual do Lagamar que, com mais de 47.000 hectares, se sobreporia a

\footnotetext{
${ }^{164}$ Decreto Estadual n. 50.019 de 20 de setembro de 2005.

${ }^{165}$ Os integrantes do GT- PEJ foram nomeados pela resolução 34 da secretaria do Meio Ambiente. Foi composta por técnicos da Reserva da Biosfera da Mata Atlântica (RBMA), do Instituto Florestal (IF), do Instituto de Terras do Estado de São Paulo (ITESP), Procuradoria Geral do Estado (PGE) e Fundação Florestal (FF). Além disso, integrou também Câmaras de Vereadores e Prefeituras envolvidas, Associações Quilombolas, Conselho Consultivo do PEJ, ong's e moradores do Parque(PEJ).

${ }^{166}$ BIM, op.cit. p. 90

${ }^{167}$ BIM, Idem, p.90
} 
diversos bairros rurais de Cananeia, repetindo o erro cometido quando da criação do Parque Estadual do Jacupiranga em 1969. Nesse ponto da discussão, torna-se necessário questionar: se um dos princípios do GT-PEJ era a efetiva participação de todos os segmentos envolvidos, por que uma proposta que evidentemente prejudicaria as populações de Cananeia afetadas pelo aumento da área de restrição ao uso de recursos naturais pelo Parque Lagamar de proteção integral chegou a ser cogitada pelo GT-PEJ?

Umas das evidências encontradas para responder a essa questão foi o relatório

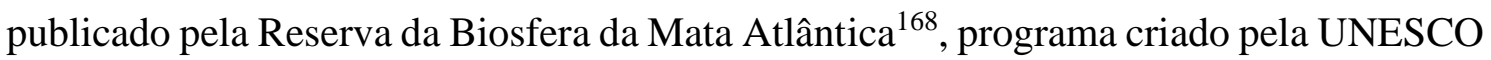
com o intuito de reconhecer e contribuir com projetos de conservação aliados à sustentabilidade, cujos integrantes contribuíram com a coordenação do GT- PEJ. Nesse relatório constam os principais representantes do Estado e das comunidades afetadas que compuseram o referido grupo de trabalho ${ }^{169}$. A composição do grupo traz a participação de diversas associações comunitárias, sobretudo quilombolas, mas nenhuma da cidade de Cananeia. No tocante a essa cidade, as únicas participações registradas foram de pessoas não citadas nominalmente e que compunham apenas o Conselho Consultivo do antigo Parque Estadual do Jacupiranga. Além disso, temos a participação de dois representantes da Prefeitura de Cananeia, dentre eles o próprio prefeito da época. Esses dados demonstram como grande parte da mobilização em prol do Mosaico era proveniente das áreas mais afetadas pelo PEJ no Médio Ribeira. A pouca participação das populações de Cananeia reflete o fato de que, inicialmente, o projeto de reclassificação do território não foi capaz de envolver efetivamente todas as pessoas que seriam afetadas pelo processo de recategorização e demarcação das novas unidades de conservação. Além disso, para os representantes do munícipio, o aumento das áreas de conservação na cidade constituiu uma proposta interessante na medida em que a ampliação territorial de áreas incorporadas

\footnotetext{
168 O Programa Homem e Biosfera (MaB - Man and the Biosphere) foi criado como resultado da "Conferência sobre a Biosfera" realizada pela UNESCO em Paris em setembro de 1968. O MaB foi lançado em 1971 e é um programa de cooperação científica internacional sobre as interações entre o homem e seu meio. Busca o entendimento dos mecanismos dessa convivência em todas as situações bioclimáticas e geográficas da biosfera, procurando compreender as repercussões das ações humanas sobre os ecossistemas mais representativos do planeta.

O objetivo central do Programa MaB é promover o conhecimento, a prática e os valores humanos para implementar as boas relações entre as populações e o meio ambiente em todo o planeta. http://www.rbma.org.br/mab/unesco_01_oprograma.asp Acesso em dezembro/2016 ${ }^{169} \mathrm{http}: / /$ www.rbma.org.br/rbma/pdf/caderno 37.pdf p. 67. Acesso em dezembro/2016
} 
às unidades de conservação no munícipio aumentaria o repasse do ICMS ecológico ${ }^{170}$, atualmente um dos maiores do Estado de São Paulo. ${ }^{171}$

Diante da ameaça de sobreposição dos territórios ocupados pelo Parque Lagamar de proteção integral que iria ser criado para compor o Mosaico de Unidades de Conservação, as comunidades locais se organizaram e formaram uma comissão que, com o apoio de um técnico do Parque Estadual do Jacupiranga, fizeram uma revisão e excluíram algumas das áreas densamente povoadas. Segundo o exposto por Carlos, a renegociação da área foi realizada pelo próprio Ocimar:

(..) quando eles vieram, eu até estava no campo jogando bola. O rapaz chegou conversando e queria fazer o levantamento. E no papel estava que, era 500 metros para lá, e 500 metros para cá da estrada. Aí, eu conversei com ele e não aceitei.

O rapaz era o Ocimar ${ }^{172}$. Então não aceitei. Falei que era muito pouco, que tinha que ser na base de 1.500 , e para lá pedi dois mil e poucos metros. Aí ele concordou.

Segundo Bim, tratou-se de um processo democrático que envolveu aproximadamente 10 reuniões nas comunidades do Ariri, Taquari e Santa Maria e uma Audiência Pública na cidade de Cananeia. Dessa forma, teria sido construído um consenso, apresentado e ratificado em Audiência Pública, em torno da diminuição da área do Parque Lagamar de 47 mil para 40 mil hectares, e da criação três Unidades de Conservação de uso sustentável na cidade de Cananeia: A RESEX Ilha do Tumba, área de trabalho destinada aos moradores da Comunidade do Marujá, ${ }^{173}$ a RESEX Taquari e a RDS Itapanhapima que compõem esse estudo. No entanto, com exceção da renegociação da área e da audiência pública realizada na cidade de Cananeia, os demais beneficiários entrevistados não associaram aspectos democráticos a esse processo.

É importante ressaltar que a noção de reserva surge a partir das lutas indígenas, cujas conquistas em torno da diferenciação no tratamento fundiário, ou seja, do direito à proteção e posse coletiva de terras, são uma constante desde a constituição varguista de

${ }^{170}$ O ICMS Ecológico constitui um dos critérios para o cálculo desse repasse no Estado de São Paulo, sendo ele próprio calculado em função da existência de espaços territoriais especialmente protegidos nos municípios do território estadual. Essas áreas são as Unidades de Conservação, conforme prevê a Lei Estadual $\mathrm{n}^{\circ} .8 .510 / 93$, alterada pela Lei Estadual no. 12.810/08.

${ }^{171} \mathrm{http}$ ://arquivos.ambiente.sp.gov.br/cpla/2011/05/2016-icms-valores-repassados.pdf Acesso em fevereiro/2017

172 Ocimar Bim é funcionário da Fundação Florestal

173 A RESEX Ilha do Tumba foi criada como área de trabalho e reserva de recursos naturais para a comunidade do Marujá que vive no Parque Estadual da Ilha do Cardoso. Trata-se, portanto, de uma unidade de conservação criada a partir do contexto de organização da comunidade do Marujá e insere-se em um processo histórico particular ligado a essa comunidade. Por essa razão, não fez parte deste trabalho de pesquisa. 
1934. O reconhecimento dos direitos originários indígenas vinculados aos territórios, às "suas raízes históricas (e não a um estágio cultural ou a uma situação de tutela)"174 resultou em uma seção própria relativas às terras indígenas na constituição de 1988 , estimulando outros grupos que lutavam pela posse de suas terras a requerem uma legislação que garantisse a posse coletiva ligada aos direitos de ancestralidade e pertencimento identitário.

Ao longo desse processo, o êxito das reivindicações fundiárias indígenas ganhou destaque, com o resultado inesperado e paradoxal de que outros setores despossuídos da sociedade, como os quilombolas e, como veremos, os seringueiros, começassem a emulá-los. ${ }^{175}$

Considerando-se que a grande maioria das terras e povos indígenas brasileiros estão na Amazônia, e que o início da luta e da resistência dos seringueiros pela permanência em territórios sociais também se deu na floresta, as novas regulamentações territoriais se tornam modelos para outras regiões com problemas similares, apresentando uma proposta que pela primeira vez deixava clara a convergência entre questão agrária e meio ambiente.

A proposta de reservas extrativistas surgiu no contexto da luta pela reforma agrária e a partir de mobilizações sociais e políticas realizadas inicialmente pelos seringueiros do vale do rio Acre, especialmente do município de Xapuri, no Acre, sob a liderança de Chico Mendes, presidente do Sindicato do Trabalhadores Rurais de Xapuri, líder do Conselho Nacional de Seringueiros e um dos fundadores da Aliança dos Povos da Floresta. O objetivo central das reservas extrativistas é conciliar a solução dos conflitos pela posse da terra com a gestão sustentável de recursos naturais, fazendo convergir políticas públicas que tendem a atuar de forma divergente: reforma agrária e meio ambiente. ${ }^{176}$

Definida como posse agroecológica, as reservas extrativistas são de domínio público desde sua origem e assim continuaram quando foram incorporadas pelo SNUC, sendo que os povos tradicionais possuem direito de permanência e uso por meio de contrato de concessão de direito real ${ }^{177}$, que pode ser revogado no caso de não

\footnotetext{
${ }^{174}$ Idem, p.08

${ }^{175}$ Idem, p.09

${ }^{176}$ SANTILLI, Juliana. Socioambientalismo e novos direitos - Proteção jurídica à diversidade biológica e cultural, p. 142.

${ }^{177}$ BENATTI, José Eder. A criação de unidades de conservação em áreas de apossamento de populações tradicionais. In: http://repositorio.ufpa.br/jspui/bitstream/2011/3076/1/Artigo_CriacaoUnidadesConservacao.pdf Acesso em novembro/2016
} 
cumprimento dos deveres por parte dos "beneficiários", dado que ssegurar a conservação da biodiversidade ambiental e cultural é um dos principais objetivos de tais territórios, segundo o SNUC. Dessa forma, essa concepção territorial que inicialmente foi concebida para contemplar os seringueiros amazônicos se estende para diversos outros povos e biomas, como quebradeiras de coco babaçu e remanescentes de quilombos. Na Mata Atlântica, em especial no Vale do Ribeira, as reservas extrativistas vão contemplar sobretudo as populações quilombolas, ribeirinhas e caiçaras que se encontram distribuídas ao longo da região em diversos contextos geográficos e socioculturais. A primeira reserva extrativista do Estado de São Paulo foi criada no ano de 2002 em âmbito federal frente à mobilização da população do bairro do Mandira em Cananeia, comunidade quilombola reconhecida pelo Estado e que hoje desenvolve o turismo e a produção de ostras em viveiros. Trata-se de uma importante experiência na região que vem aos poucos construindo sua viabilidade econômica por meio de projetos sustentáveis.

A concepção da RESEX Taquari no Mosaico de Unidades de Conservação foi implementada por outro caminho: mostrou-se como alternativa política para viabilizar uma área de trabalho, ou seja, de manejo de recursos naturais, voltada para comunidades que foram cercadas pelo Parque Estadual do Lagamar, posto que este, como unidade de conservação integral, não permite o acesso aos seus recursos pela população local. A RESEX também constitui uma área de pesca voltada para os pescadores tradicionais de Cananeia. Contempla, assim, uma demanda da Colônia de Pesca Z9 Apolinário de Araújo, que representa pescadores de todo o município. Dessa forma seus limites geográficos foram pensados de forma a incluir o menor número de moradias possível. Segundo o Plano de Uso realizado para a área, existem 17 famílias na área da RESEX. Entretanto, muitos não são moradores, possuindo casas ou "ranchos" utilizadas apenas para o trabalho, sobretudo na pesca. O Bairro Santa Maria e Taquari não foram citados pelo plano de uso e trata-se de um documento pouco conhecido até mesmo por Carlos França, membro politicamente ativo da comunidade e conselheiro titular tanto do Conselho Deliberativo da RDS Itapanhapima/RESEX Taquari, quanto do Conselho Consultivo do Parque Estadual Lagamar.

Diante da compreensão do complexo quadro territorial e político que envolveu a criação dessas unidades de conservação de uso sustentável em Cananeia, percebemos que elas não foram planejadas a partir de uma demanda da comunidade local, e sim como um rearranjo político-institucional pensado tecnicamente com o intuito de garantir a viabilidade do Mosaico de Unidades de Conservação do Jacupiranga. Com exceção da 
identificação e exclusão das áreas povoadas que ficariam no interior do Parque Lagamar por meio do cadastro dos moradores, não foi realizado nenhum estudo aprofundado sobre os conflitos e as necessidades daqueles que foram incluídos como beneficiários das reservas, tanto a extrativista, quanto a de desenvolvimento sustentável. Criadas em 2008, apenas em 2010 realizou-se um primeiro estudo diagnóstico da área por meio do Plano de Utilização previsto pelo SNUC e que, segundo os moradores que colaboraram com este trabalho, também foi realizado de forma superficial e com pouca participação dos envolvidos. Compartilhando tais críticas, apresentamos a seguir narrativa protagonizada por Dirce e Armando Davi, com a participação de seu filho e Nivaldo e sua nora Talita. 


\section{$\underline{\text { Seu Armando e Dona Dirce }}$}
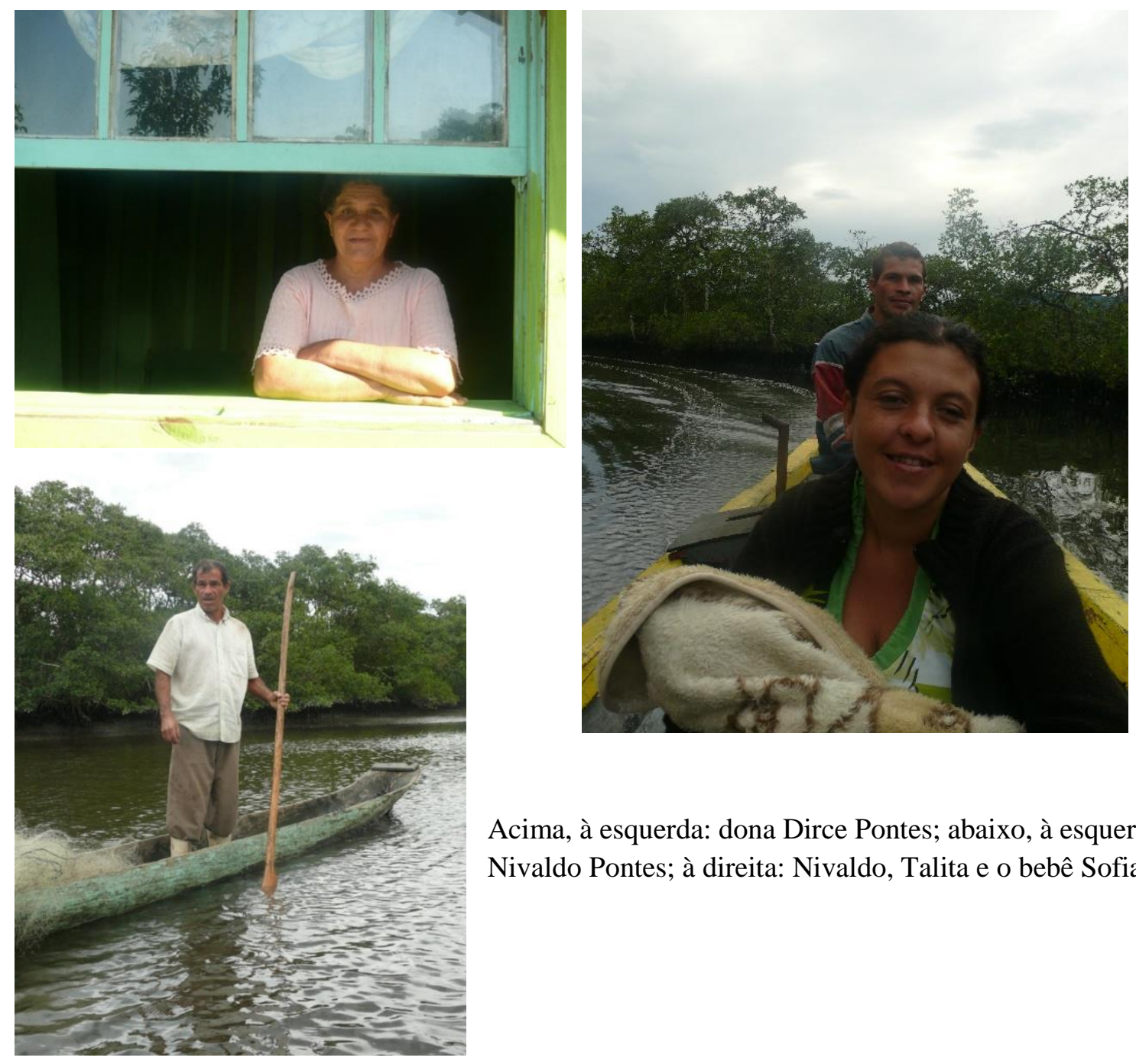

Acima, à esquerda: dona Dirce Pontes; abaixo, à esquerda: Nivaldo Pontes; à direita: Nivaldo, Talita e o bebê Sofia.

Quando cheguei ao bairro Retiro que faz parte da Reserva de Desenvolvimento Sustentável Itapanhapima, no sítio de seu Armando (A) e Dona Dirce (D), percebi que o casal e a família do filho viviam tão próximos - basicamente relacionando-se por dias e dias apenas entre eles - que não seria conveniente a realização de entrevistas separadas. Seria extremamente estranho e pouco confortável pedir que cada um realizasse a entrevista de forma privada. Todas as conversas foram realizadas na cozinha, com livre acesso de todos. Portanto, acabou-se por constituir uma entrevista realizada a três mãos principais, e também a colaboração (ouvindo, falando pouco, mas interagindo com sorrisos e expressões) da nora Talita (T), do filho Nivaldo $(\mathbf{N})$ e da pequena Sofia de apenas três meses. Entrevista realizada em julho de 2014. 
"Nasci aqui e acho que vai ser aqui até a morte. A vontade é essa. Mas você sabe que tem as caídas para o caminho. No caso dessa RDS, para nós foi uma coisa muito ruim... Parece que foi ruim e para nós foi ruim mesmo. Já está tirando a nossa tradição."

Seu Armando

E eu prefiro perder tudo para o Estado, menos que fique para esses grileiros que quase nos matou aqui! Eu falei isso mesmo para ele! Que eu perca tudo para o Estado, mas que não fique com essas pessoas que quase acabaram com a minha vida.

Dona Dirce

D - Então conta a tua história ué!

$\boldsymbol{A}$ - Eu não sei história!

$\boldsymbol{D}$ - Eu nasci no Taquari, nasci em casa, mamãe disse que eu chamei a parteira de vó até ela morrer.

A - Eu nasci aqui mesmo. Nasci em casa. A minha mãe era parteira. Joaquina Pereira Davi.

D - Meu filho Adelmo ${ }^{178}$ nasceu em casa, foi a minha sogra a parteira. Minha outra filha Antônia, Rosilda, todos nasceram em casa. Eu nunca fui ao hospital, quer dizer, só do primeiro eu fui para o hospital e depois a minha sogra que fez os partos tudo em casa.

Sempre deu tudo certo, eu fazia o pré-natal tudo certinho, vinha tudo marcadinho pelo médico que acompanhava e se estava tudo bem, se não tivesse algum perigo a minha sogra ficava comigo, mas se tivesse algum perigo ela já trazia para o hospital.... A minha sogra era parteira boa viu, ela só não tinha carta de parteira, mas era uma parteira muito boa. Ela morava no Barranco Alto, lá para o Paraná.

$\boldsymbol{A}$ - As irmãs dela, a mãe dela, eram tudo parteira. Nós somos cinco irmãs e dois irmãos. Tem dois em Pariquera - Açu ${ }^{179}$ e o resto mora aqui em Cananeia. Eu e meu irmão que mora lá em cima, o Gentil, moramos no sítio. Sabe por que surgiu esse nome de Itapanhapina ${ }^{180}$ ? O meu pai contava que na época da guerra tinha um comandante que estava na guerra e eles vieram por aqui para vir pelo mato. Parece que na guerra de trinta e dois e eles acamparam lá em cima na pedra, um grupo de soldados e um comandante que estavam com eles. Eles dormiram lá em cima no topo da pedra. De manhã quando eles desceram, chegaram no vargedo e quando o comandante chegou lá em baixo e olhou pra cima ele falou: eita pedra empina! Aí já trocou né? De eita pedra empina para Itapanhapina! O meu pai, ele disse que surgiu esse nome de Itapanhapina por causa disso. Então qualquer coisa que perguntavam eles diziam: ah lá no Itapanhapina!

\footnotetext{
178 Adelmo é um dos filhos de seu Armando e Dona Dirce. Foi também colaborador desse trabalho. Atualmente é funcionário da Fundação Florestal, órgão estadual responsável pela gestão das Unidades de Conservação do Mosaico de Unidades de Conservação Jacupiranga na cidade de Cananeia.

${ }^{179}$ Cidade próxima à Cananeia.

${ }^{180}$ Segundo senhor Armando, a população local chamava a região de Itapanhapina e não Itapanhapima como o nome oficial da reserva.
} 
D- É um nome bem estranho, né? Eu procurei no dicionário, fala que Retiro ${ }^{181}$ significa: muito distante, isolado e retirado. No dicionário está assim. Com uma maré seca dessa, só Deus né? Porque ficamos isolados mesmo. Eu falo que eu tive muita sorte, eu morei aqui e depois eu passei lá mais para cima por causa dos bichinhos e do povo que estavam judiando da gente muito. Eu tenho muita sorte porque eu tive dez filhos tudo com saúde e criei os dez! Imagine que o Adelmo ${ }^{182}$ com apenas cinco dias eu o levei para Cananeia porque ele nasceu em casa e quando pesamos faltou cem gramas para cinco quilos, ele era forte mesmo! Só o Elizeu que puxou a avó do lado do Armando, mas do meu lado era tudo grandão!

A - Daqui em Cananeia a remo leva três horas e pouco. Ah de primeiro era tudo no remo, até eles estarem meninos grandes era tudo no remo, no tempo do meu pai... hoje que nós temos um barquinho.

$\boldsymbol{D}$ - Tem aquela história que contei de Adelmo que fez a gente remar quase meia noite de canoa a remo. Ele tinha seis meses quatro dentes na frente, mordeu e arrancou o pedacinho do bico da mamadeira e aí não aceitou mais a mamadeira de jeito nenhum. Fiz o leite, colocava e ele não mamava. Gritava, chorava, eu pensei: ele deve estar com alguma dor, vai morrer esse menino! Arrumei tudo na bolsa louca da vida, joguei ele na cama chorando, não tinha o que acomodasse ele! Remamos daqui a Cananeia. Tinha uma lanchonete que chamava Monte Branco e fomos por fora tudo, lá pela balsa. E ele falou: vamos chegar nessa lanchonete, tem mamadeira, tudo e você compra, lava e experimenta para ver se ele mama. Chegamos lá compramos a mamadeira, mandamos a moça lavar, coloquei o leite morninho e ele mamou tudo e dormiu. Fui para o hospital, o médico examinou ouvido, garganta e falou: olha ele não tem nada, o que ele tem mesmo é sono! Quase me matou por causa da mamadeira, ele todo arroxeado de chorar. Tudo por causa da mamadeira que ele cortou o bico e não queria!

$\boldsymbol{A}$ - Aqui é muito bom demais. Muito gostoso esse lugar. Quando a gente era molecada, era a coisa mais gostosa para trabalhar junto. A gente subia a serra com um saco de arroz batido nas costas, para ver quem chegava adiante lá em cima. Era muito bom demais, depois foi desanimando lá no sítio, foi todo mundo saindo... O pessoal foi procurando melhora né? Um saiu foi procurar emprego, depois outro saiu... tudo foram trabalhar de empregado e acharam que era melhor e não voltaram mais. E não voltam porque depois de sair, a família começa a crescer, os filhos começam a estudar e não voltam mais... Só eu só fiquei! Eu acho que eu gosto demais daqui.

D - Nós e o seu irmão Gentil que também morava aqui e foi lá para cima para trabalhar na fazenda do Hélio como caseiro. Estudaram também aqui todos os filhos dela, da minha irma $\tilde{a}^{183}$. Quando eu morava no Taquari o meu pai trabalhava só na roça e nós pescávamos. Nossa senhora, o meu pai era viciado em ostra! Quando amanhecia o dia, seis horas ele já estava amolando a foice, e minha mãe perguntava para ele: você não vai pescar hoje? E ele dizia: não, hoje eu vou para roça. Plantava e vendia farinha direto. Quando chegava o tempo da festa de agosto que eu lembro que era aquela festa que tinha todo ano em Cananeia, a minha mãe falava: quinze dias agora só para trabalhar, só para vender farinha. Vender e comprar calçado e roupa para vocês irem na festa! Eu, o meu irmão e a minha outra irmã que já é morta hoje. Eu e minha irmã íamos para a roça. Quatro ou cinco sacos de mandioca amontoado, nós íamos raspar a

\footnotetext{
${ }^{181}$ Retiro é o nome tradicional de um dos bairros que hoje constitui a RDS Itapanhapima.

${ }^{182}$ Adelmo é filho de Dona Dirce e atualmente guarda parque no PEIC, Parque Estadual da Ilha do Cardoso. Além de ser um dos meus primeiros contatos, indicado pelo gestor da unidade de conservação, também me levou até a área da reserva, uma região de difícil acesso.

${ }^{183}$ Seu Armando é irmão de Seu Gentil; Dona Dirce, sua esposa, é irmã de Dona Isabel, que é casada com Seu Gentil. Eles também colaboraram com esse trabalho.
} 
mandioca, um lavava, outro ralava e depois outro prensava. Minha mãe deixava aqueles sacos brancos, me lembro como se fosse hoje, ela arrumava tudo em cima de uma mesa, cheio de farinha. Todos aqueles sacos brancos, eu ia lá batia em cima para sair aquele pó do saco e a nossa mão ficava tudo branca, eu com o Zé meu irmão! O meu pai colocava na canoa aquela farinhada e ia vender para comprar roupa e calçado para gente não ir de pé descalço na festa de agosto. ${ }^{184}$

(Nesse momento o filho Nivaldo, a nora Talita e a netinha Sofia chegam para tomar um café, aproveitar o fogo e a conversa).

$\boldsymbol{A}$-É, primeiro era melhor que hoje. Meu pai fazia compra de ano em ano no mercado. Comprava de tudo, carne seca, óleo de comida. Ele vendia a mercadoria dele e comprava isso, porque em casa nós tínhamos arroz, feijão para passar o ano. Virava o ano e a gente ainda tinha tudo em casa. Tudo plantado.

D - Eu lembro, nunca vi o meu pai comprar um saco de arroz em casa. Até eu casar, e eu casei com dezenove anos, eu nunca vi o meu pai ir na venda comprar arroz e feijão. Se eu falar que vi é mentira. O meu pai tinha tudo e até dava para os outros. Ele enchia as bacias de feijão e dava para os vizinhos, muito, muito, arroz e feijão. Isso depois que nós ficamos grandes e que nós ajudávamos o meu pai. Quando nós éramos pequenos fazia falta porque ele tinha que dar conta de tudo, mas depois que nós crescemos, esses negócios de roça eram tudo plantado e tinha muito.

$\boldsymbol{A}$ - Sal tinha que comprar, sal, óleo.

$\boldsymbol{D}$ - Mas tinha muita banha de porco, quando a gente era pequena, era banha.

Talita - Lá no Paraná eles vendem assim sabia? Eu não compro lata de óleo, eu compro mais esses tabletes de banha. A maioria do povo não compra lata de óleo, compra mais esses tabletes como margarina que economiza mais.

$\boldsymbol{A}$ - A gente ia no chiqueiro do porco, deixava dois capados para engordar. O pai dizia: esse é para engordar, para nós fazermos banha. Então ele os deixava bem gordo e depois matava aqueles dois capados e derretia tudinho, duas latas dessa de dezoito litros enchia bem cheio, virava o ano gastando aquela banha ainda. Ah, ninguém comprava óleo não.

D - Vivia bem... vivia bem mesmo.

$\boldsymbol{A}$ - Açúcar também não comprava por que fazia açúcar de cana, é da garapa. Já fazia o café com a garapa. No lugar da água colocava a garapa e já colocava o pó de café.

$\boldsymbol{D}$ - A minha mãe deixava ferver aquela moenda de cana. Eu, minha mãe, meu pai e os meus irmãos moíamos cana. Os meus irmãos que eram menores iam colocando a cana para moer e a minha mãe pegava e enchia balde, colocava no tacho e fervia no fogo. E ia fervendo o dia inteiro, aqueles tachos cheios, dessa altura. Ficava um tiquinho no fundo e eu pensava: que danado, quanto mais minha mamãe coloca aí, mais fica pouquinho, some tudo! E no final de tudo dava meio tachinho de açúcar, que a minha mãe ia apurar e ficava feito pedra. Depois ela arrumava no pilão, moía e enlatava tudo esse açúcar. E era gostoso de comer! A nossa vizinha daqui, a dona Joana, até outro dia fazia e mandava um vidrinho para nós recordarmos do tempo da nossa mãe. Moía a cana e fazia açúcar! Não fica branquinha, fica amarelinha! E fica gostoso para temperar o café.

$\boldsymbol{A}$ - Farinha era só de mandioca.

D - Dava para bolo mas não ficava igual o trigo. Minha mãe fazia bolo com massa de arroz, misturava tudo, fazia cuscuz de arroz.

${ }^{184}$ Talita: "Festa de aniversário da cidade e festa dos barcos e essas coisas." 
A - A mistura era biju, cuscuz de arroz que hoje dizem que é tapioca. Então era essa daí a mistura. Colocava amendoim, coco, colocava indaiá, uma frutinha que dá em caixo grande e que ainda tem muito. Aquilo ali você seca no sol, quebra e sai o miolinho, pequenininho assim, é que nem coco. Mistura com massa de arroz ou massa de mandioca, para fazer cuscuz, tapioca e fica muito gostoso!

Nivaldo - Tem Indaiá sim, tem dois caixos ali.

Talita - É um roxo, bem roxinho.

$\boldsymbol{A}$ - Pão caseiro eu nunca comi no tempo do meu pai e da minha mãe. Comia tapioca e o cuscuz. Também fazia o biju de manipuba como a gente falava. Colocava a mandioca de molho dentro de um saco no lago, deixava lá oito dias. Depois que a mandioca estava mole, ia lá, tirava, prensava, enxugava, colocava no pilão, socava e ia coando, tirava a massa e ia fazendo biju. Aquilo ficava muito gostoso.

D - A minha mãe fazia perereca. Doce, salgado, tudo. Mas eu acho que a tapioca é o mesmo do biju, é a mesma massa.

A - Mas o biju também põe o que quiser né? Bom, a única coisa difícil aqui é o ganho do dinheiro. É isso que é difícil. Mas no mais tudo é bom.

D - É que o ganho da gente depende só do mar, só da pesca. E da ostra.

\section{"Nós exploramos o que é nosso e damos para eles.”}

\section{Armando}

A- Desde 1995 eu tirei a minha carta de pesca por causa da perseguição da polícia ambiental. A polícia ambiental já vinha em cima da gente no mar, diziam que iam levar barco, levar a canoa, levar a gente, levar tudo. Ele dizia: Não, o senhor tem que tirar sua carteira. E eu sempre falava: Mas como eu vou pagar a carteira sendo que eu ganho pouco. Era o Elizeu, que era da polícia ambiental. Hoje é aposentado, é segurança, mas aquele homem... Meu Deus do Céu.

Hoje o Wagner Klimke é o presidente da colônia de pesca ${ }^{185}$, onde tiramos a carteira de pesca. Na verdade a colônia de pesca de Cananeia, olha, pelo que a gente paga, pelo dinheiro que eles resgatam ali, eles não fazem nada não. Lá só tem só exame de vista.

D- E é pago o exame. Mais barato mas é pago.

Mas para quem é associado ainda paga um pouquinho, metade do valor do exame. Mas a taxa da colônia é cento e cinquenta anual.

D-Cento e cinquenta só a colônia, fora o INSS.

A-Eu pagava INSS anual, mas eles recebem de seis em seis meses. Eu não sei direito quanto é, parece que é noventa e dois reais, uma coisa assim. Os quarenta e três que eu falei é de seis em seis meses, dá oitenta e seis. Mais cento e cinquenta da colônia sai pesadinho né? Porque a gente ganha pouco. E não compensa, porque a única coisa que a gente ganha é a aposentadoria mas isso é um direito.

Eu não sei como tem tanta gente que vem vender a ostra e o peixe daqui para fora. Chega de longe de Cananéia, chega lá do Sul, chega lá de São Paulo e em uma semana, duas semanas eles já arrumam tudo e já saem vender para fora as coisas daqui. E nós que somos os donos temos que vender para eles. Nós exploramos o que é nosso e damos para eles. Bem dizer damos, porque eles que vem comprar e ninguém vai para

\footnotetext{
185 Colônia Z9 de Pescadores “Apolinário Araújo”. http://coloniaz9depescadores.blogspot.com.br/2013/04/mercado-municipal-de-cananeia.html Acesso em março/2017.
} 
cima deles, vem para cima de nós. Aqui todo mundo vende para fora, ali no Itapitangui ${ }^{186}$ eles vendem pra Santos, São Paulo, para todo canto. Mas no caso, eu digo que é tudo por de baixo dos panos, é tudo clandestino. Eu já conversei com o Marcos e seu Osmar ${ }^{187}$, eu falei isso para eles. Eles também falam que isso é tudo por debaixo dos panos, e eu falei: Então por que a justiça não vai em cima deles, vem em cima dos pobres?

D- Eles compram e levam para o CEASA. Porque a gente não tem condição. A gente não tem um carro, a gente tira a ostra daqui e passa para eles. Por exemplo o Jacques que compra ostra de quantidade. Ele tem a depuradora.

A - Ele tem a depuradora, a fábrica. Tem o SIF ${ }^{188}$. Tem firma mesmo legalizada dele.

D - Ele pega ostra de quase todo mundo, paga muito barato e paga quando quiser.

A - Essa empresa dele muda de nome direto, mas era Chacostra quando eu entregava lá. É aqui perto do Mandira ${ }^{189}$, mas não é pela estrada, é pelo mar. Chega por terra, mas só depois do Porto Cubatão ${ }^{190}$ que tem uma estrada de barro que entra assim, que é onde é a entrada do Jacque.

$D$ - Todo mundo conhece. Ele é muito conhecido.

A - Faz muito anos que ele trabalha por aqui.

D - Ele demora muito para pagar mas paga. E paga muito barato, tira muita quantidade e acaba com o mangue. Ele compra de caixa, ele compra miúda, ele compra tudo que vai, só que o preço não compensa. Agora para falar a verdade eu não sei o preço porque faz tempo que eu não vendo ostra para ele. A gente vendia para o Jean lá do Mandira e para o Renildo que passou a gente para trás também, pegou a ostra e não pagou. Ele é do Itapitangui ${ }^{191}$.

D - Ficou devendo mas o coitado também é pobre, eu sei lá o que aconteceu com ele. Ele está até hoje devendo para nós. Outro dia ele encontrou com a gente, pediu perdão, perdão, e o Armando disse está perdoado, se quiser pagar, pague! Mas coitado dá dó eles são pobrezinhos também.

A - A dívida é dele. Eu não sei cobrar ninguém.

$\boldsymbol{D}$ - Eles são moradores de lá do Itapitangui, o meu filho também mora lá. Agora não dá para falar mal deles porque o meu filho está lá! O Antônio.

$\boldsymbol{A}$ - Há uns dois anos a gente vendia para o Suíço. Ele é de lá da estrada da ponte, trabalhava com criação de camarão. Todo mundo conhece ele.

D - Ele pagava bem a ostra. Quando ele começou a comprar a nossa aqui, a turma foi vendo e pronto. Já mandaram o florestal em cima dele. Porque ele pagava quatro reais a dúzia. E os outros pagavam dois reais.

A - Um e cinquenta a dúzia. Essa é a média: um e cinquenta. O de agora é, não passa disso.

D - Agora que não vende mesmo. Agora tem gente que está passando fome, como meu genro que vende ostra. Nós não passamos fome porque ele é aposentado, mas quem vive de ostra mesmo, meu deus, passa necessidade. Essa época com frio, não tem turismo, não tem nada, passa fome. Quem tem família grande né?

\footnotetext{
${ }^{186}$ Bairro rural de Cananeia continental onde se inicia a estrada de terra chega até o Ariri, fronteira com o Paraná.

${ }^{187}$ Funcionários da Fundação Florestal responsáveis diretamente pela gestão da RESEX no período em que ocorreu a entrevista.

${ }^{188}$ Sistema de Informações Gerenciais do Serviço de Inspeção Federal. O Sistema atesta a qualidade dos produtos de origem animal, sob o aspecto sanitário e tecnológico, oferecidos ao mercado consumidor.

${ }^{189}$ Reserva Extrativista Mandira, mais conhecido na região como Quilombo do Mandira.

${ }^{190}$ Bairro rural de Cananeia continental.

${ }^{191}$ Bairro rural de Cananeia continental.
} 

banana.

D- Aqui na nossa reserva pelo menos pode plantar algumas coisas como a

A- Por enquanto pode, mas olhe!

D-Disse para mim um homem que veio de São Paulo quando eu estava sozinha em casa, só estava com a Tatiane, que é lá do Marujá e o Armando estava pescando, que nem casa de material pode fazer. Só casa provisória igual essa aqui, porque casa assim se ficar seis meses abandonada, ela apodrece. Mas nem casa...

Talita - Mas porque será que não pode?

$\boldsymbol{D}$ - Ele falou que não pode.

Talita - Mas nem nesse pedacinho aqui que é deles?

Nivaldo - Eles querem que as pessoas morem em barraco. Pode fazer mas tem que pedir ordem. Demora um pouco. Eu fiz um pedido de casa lá no Marujá192 onde eu morei por uns três anos. Demorou uns quatro anos e eles falaram: ah saiu o seu pedido de casa lá! Eu falei: então dê para uma pessoa que precise porque eu não quero mais esse daí! Depois que eu já tinha perdido a esperança.

D- Ele já tinha pedido placa solar, luz, água, ficou lá e veio embora desanimado. Depois saiu.

Nivaldo - Deu uma raiva!

\section{acabam.”}

“A gente não acaba com o que é da gente. Eles que

Nivaldo

A - É tudo complicado, você vê, a gente tinha barraco na Ilha do Tumba ${ }^{193}$, barraco para pesca. O seu Osmar da Fundação Florestal veio e falou assim: seu Armando tem que tirar o barraco de lá e limpar o lugar porque ficou dentro do parque, nós arrumamos outro lugar para o senhor fazer, na mesma ilha mas em outro lugar. A hora que nós tiramos o barraco de lá, os cariocas entraram por lá, estão pegando caranguejo e nós ficamos sem! Para você ver como é isso daí né?

Talita - A maioria mora em Cananeia.

Nivaldo - É nada, eles vêm do Rio mesmo porque lá eles também pescam. Eles pescam lá em Angra dos Reis.

A - A gente fica tão vendido no meio disso tudo que a gente nem sabe o que fazer!

$\boldsymbol{D}$ - Os de fora que acabam com as coisas da gente.

Nivaldo - A gente não acaba com o que é da gente. Eles que acabam.

Talita - Vem gente do Paraná tirar coisa daqui.

$\boldsymbol{D}$ - A gente vai no mangue para tirar uma ostra. Vê uma ostra pequena e não pega, deixa ela lá porque ela vai crescer. A gente tira com cuidado para não machucar, e eles não. Se der para cortar com o mangue eles levam tudo. Eles não estão nem aí, não é deles mesmo! A gente protege. Se você entrar nesse sítio aqui, é lindo, você anda só por baixo de árvore.

\footnotetext{
${ }^{192}$ Comunidade tradicional moradora da Ilha do Cardoso (Parque Estadual Ilha do Cardoso - PEIC)

${ }^{193}$ Reserva Extrativista do Tumba cujos beneficiários são os moradores da comunidade do Marujá, na Ilha do Cardoso.
} 


\section{"Nós não sabemos ainda onde é a nossa área de trabalho porque a gente está com um parque atrás de nós e um parque na nossa frente.”}

Seu Armando

A - Eu achava que no caso do seu Osmar por exemplo que é o gestor da reserva, a primeira coisa que ele tinha que fazer para o morador tradicional era proteger a nossa área. Porque o seu Osmar é da Fundação Florestal e ele tem força para isso, mas ele disse que veio para isso e não fez. Ele estragou, ele me tirou de lá porque disse que era parque e deu para os cariocas!

$\boldsymbol{D}$ - Mas ele não deu nada para ninguém!

A - Na verdade ele não deu para ninguém. Mas ele deu a mão para eles e me deixou para trás, eu que sou morador! Nós não sabemos ainda onde é a nossa área de trabalho porque a gente está com um parque atrás de nós e um parque na nossa frente. O Parque Lagamar está atrás de nós e a Ilha do Cardoso que também é parque, está na nossa frente. Nós vamos para lá e não pode, viemos para cá e não pode também!

Nivaldo - Lá na Ilha do Tumba é reserva da turma do Marujá.

A-É, eles tinham concordado que a gente trabalhasse ali, mas até agora não foi marcado o nosso ponto.

D - O ponto para fazer barraco de pesca.

A - Na verdade, como eu falei para o seu Osmar, o pessoal do Marujá não tinha direito de pegar a Ilha do Tumba para eles. A coisa mais errada que o senhor fez foi ceder a Ilha do Tumba para eles.

$\boldsymbol{D}$ - É que eles vivem de turismo.

Nivaldo - Ah mas eles também precisam, eles moram no parque e eles não tem como tirar nada de lá.

$\boldsymbol{D}$ - Eles precisam de uma madeira para o cerco.

A - Eu sei mas eu também sou um morador tradicional do parque e eles tem direito de tirar do parque.

Nivaldo - Não pode, no parque a lei diz que não pode nada!

$\boldsymbol{A}$ - Aonde que não? Se tem morador dentro do parque e já foi criado o parque com morador dentro, como é que não pode?

Nivaldo - Mas é parque. Tudo ali é Parque da Ilha do Cardoso mesmo. O pessoal mora ali onde é a restinga, a ponta entendeu?

$D$ - Está tudo no parque.

A - E a gente, para tirar madeira, tinha que ser do parque, dentro do Lagamar que é aqui atrás.

Nivaldo - O que eles deixaram para nós não tem madeira para fazer nada.

$\boldsymbol{A}$ - Ninguém sabe até onde é a reserva, só no mapa. Mas nós não entendemos de mapa e eles mostram no mapa. Parece que nem eles sabem! Porque a gente pergunta onde está a divisa do parque e eles precisam ver no mapa. Nem eles sabem. Se você me disser, seu Armando me leve na divisa do parque eu não sei levar.

Nivaldo - O que eu sei, é que do morro para lá, é parque. Aqui é tipo um Marujá, uma parte mais baixa e uma parte mais alta. Então para lá é o parque e vai afinando. A parte fina é a reserva e para lá, no morro, é o parque. É assim que eu entendi que eles falaram. Tem lugar que o limite é longe e tem lugar que a reserva pega um pedaço pequenininho.

D - Não tem madeira para canoa. Até para remo se bobear não tem madeira.

Nivaldo - Canoa, remo, essas coisas não têm nada.

$\boldsymbol{A}$ - Só o que sobrou pra nós foi à área de pesca, e ainda isso, muito pouco. 
D - Pouquinho porque pega da Ilha do Cardoso e vai até a ilha do Tumba. Daí para lá nós não podemos mais porque é Maruja já.

A - Eu falei para o seu Osmar, o Marujá tem o meio de vida deles que é o turismo. Não é a pesca, eles têm outro meio de vida.

Nivaldo - Eu sei pai, mas tem umas mil pessoas que moram ali, todos eles têm carteira de pesca!

D - Tem, mas nenhum pesca!

Nivaldo - O serviço deles não é fichado no Cardoso, não tem registro de trabalho com turismo.

D - Mas turista não aposenta, turismo não paga nada ali! A minha tia morreu $e$ não conseguiu aposentar pelo turismo. Porque ela não pagava nada e já estava com sessenta anos. Então ela não aposentou.

$\boldsymbol{A}$ - É muito turismo aqui. Aumenta bem as vendas de ostra, mas é só na temporada do verão. Depois no inverno cai a venda. Não dá para guardar né? Mas no caso deles ali de Marujá, eles ganham mais dinheiro por ali e até que dá! Mas no nosso caso não.

$\boldsymbol{D}$ - Mas não é grande coisa ali também.

$\boldsymbol{A}$ - Não, ali eles tiram bem, só não tiram mais porque eles não sabem trabalhar. Ali eles têm até controle para não ir muita gente, porque vai gente demais.

$\boldsymbol{D}$ - Tem que guardar dinheiro porque no inverno lá eles não ganham nada.

Talita - Mês de julho que começa a festa da Tainha e junto com a festa do Marujá tem a festa do mar de Cananeia.

$\boldsymbol{A}$ - Eu acho que se a comunidade está dentro da Ilha do Cardoso, porque tem várias comunidades que estão dentro do parque, eles tinham que lutar pelo lugar deles $e$ não pular lá para o lado. Porque o lado tem dono. Cada um ter o seu espaço. Mas quando eles avisaram só disseram que ia virar reserva e parque.

D - Que já tinha virado parque.

$\boldsymbol{A}$ - Já veio tudo feito, eles iam fechar tudo né? Iam fechar tudo no parque.

D - E quando a gente soube, veio um casal de advogados, você não ouviu falar de Doutor André? Da Casa da Floresta ${ }^{194}$. O Doutor André e a Malu. Eles são contratados, vieram aqui em casa. Eu tinha o telefone deles aqui, eles falaram que tudo que nós podíamos fazer e não fazer, se nós quiséssemos plantar arroz, milho, feijão, tudo que nós quiséssemos plantar nós podíamos, que não iam tirar a nossa tradição, mas para desmatar assim e queimar não pode.

Nivaldo - Mas ninguém faz nada, fica com medo deles.

Talita - Não vê a dona Tuca lá? Ela falou que o pedaço dela não entrou no parque.

D - Nós encomendamos farinha com a Dona Tuca ${ }^{195}$, dia 29 tem que buscar.

Talita - Lá tem de tudo lá, ela vende mandioca, inhame, tudo plantado na terra dela. Tem de tudo o que você imaginar... Tem mel, tem mandioca, tem farinha, tem arroz, feijão... Ela perguntou para mim, ela disse que tem de tudo eu encomendei farinha e mel dela pra mim. Peixe ela vende. Ela é velhinha né dona Dirce? Em Cananeia é sábado, porque tem terça que é da cidade e sábado é ali no Rocio, eu não sei se desmancharam, porque esses dias eu estava lá e cercaram a praça. Eu não sei se eles estão arrumando ali por causa da feira.

Nivaldo - Mas a feira está tendo em outro lugar.

Talita - É só perguntar ali onde é feira do Taquari. Sabem, a feira da turma do Taquari.

${ }^{194}$ Organização não- governamental responsável pelo plano de uso realizado para as unidades. Estudos que precedem a realização do plano de manejo.

${ }^{195}$ Moradora de área próxima à Resex Taquari. 
$\boldsymbol{D}$ - Ela tem até nota para vender, tem tudo.

A - Eles vendem com certificado, com selo de pureza, o Clodo lá vende tudo lá com selo. Ele mora no Rio Branco ${ }^{196}$. Na entrada ali do Itapitangui. Você já foi no Pitu? Fica na estrada do Pitu ${ }^{197}$. É facinho.

Talita - A minha irmã ia de bicicleta. Eu nunca fui mas ela achou perto. Foi ela, $o$ marido, e as crianças, foram pedalando e foram conversando, mas eu fui de carro $e$ achei longe!

D - Eu fui num curso de planta ali no Clodo ${ }^{198}$.

Talita - Tem pé de jaca, tem bananeira.

$\boldsymbol{D}$ - Ele tem muitos tipos de planta lá, nossa, muita, é lindo mesmo! Palmito pupunha. Tem planta que nasce, planta nativa. Você vai lá e você anda é tudo planta, lá ele tem laranja, banana.

A - É tipo eco floresta.

$\boldsymbol{D}$ - É, tem árvore também junto. Eu andei tudo na plantação dele e quando eu saí de lá já era tarde!

A - Eu falei que se eu tivesse um sítio igual desse aqui, que nem desse jeito... poxa!

D - É limpo e por baixo é banana, laranja, palmito, é fruta. Aquele dia ele trouxe para mim banana passa e o que foi que ele trouxe mais?

A - Fica ali na estrada. Muito longe. Longe e ruim a estrada. Mas chega de carro. Sabe o Selmo ${ }^{199}$ é primo dele, do Clodo. Aqui também tinha banana para todos os lados aqui, mas agora acabou. Hoje não tem mais nada e a onde era bom de plantar ficou no parque. Por isso eu disse isso para o seu Osmar quando esse doutor André veio aqui. Ele veio à toa. Porque ele deu o ponto de limite lá onde era uma tapera minha em que eu morava, lá em cima que foi onde eu criei toda a minha família.

$\boldsymbol{D}$ - Nós mudamos um tempo para lá. Mas sempre tivemos casa aqui.

$\boldsymbol{A}$ - Era lá em cima, e lá agora é parque. O doutor André marcou o ponto da reserva lá. Mas eles trouxeram o ponto no pé morro, dá trezentos metros daqui lá. É o que eu conheço mais ou menos que deve ser a divisa do parque, dá esses trezentos metros da minha casa ali.

Talita - Aí vai indo, vai indo, diminuindo.

$\boldsymbol{A}$ - Você que está mais por dentro, você sabe dessa alteração do parque? As pessoas que fizeram a reunião com a gente aqui, falaram que é cinco anos para ter essa alteração. É uma turma de São Paulo, uma japonesa, o nome deles eu não sei. Eles vieram aí com o seu Osmar para conversar, vieram eles, o seu Osmar, uma turma deles.

$\boldsymbol{D}$ - Aquela que eu fiz comida no fogão de lenha que eles queriam?

A - Isso. Como chama a japonesa lá? Ela falou o nome dela.

Talita - Ela falou o nome mas eu não lembro.

$\boldsymbol{A}$ - Acho que alguma coisa anda acontecendo... O Tumba não era parque, era reserva e a moça falou assim para nós: o parque não pode diminuir de jeito nenhum. Então o parque vai ter que tirar de algum lugar para repor essa parte que vai tirar aqui para aumentar a reserva. O parque não pode diminuir, e depois disso já saiu um pedaço da Ilha do Tumba que virou parque. Então eu pensei: acho que está andando porque já saiu alguma coisa.

\footnotetext{
196 Bairro da área rural e continental de Cananeia.

197 Cachoeira do Pitu em Cananeia.

198 Proprietário do Sítio Bela Vista no bairro Rio Branco em Cananéia. Possui muitas experiências no sistema de agrofloresta e sedia cursos de capacitação para os moradores de áreas rurais, como os oferecidos pelo SENAR - Serviço de Educação Nacional Rural

${ }^{199}$ Funcionário da Fundação Florestal na ocasião da entrevista.
} 
Eles falaram que se o tamanho mudar mais para frente, o mesmo que aumentou vai ter que voltar para o parque.

Nivaldo - Então não vai adiantar nada!

$A$ - É isso que eu quero ver né?

Nivaldo - Porque tira aqui e tem que comer lá na frente porque não pode ficar menos.

Nivaldo - Do parque não pode tirar nada!

A - Vai cobrir um santo para descobrir outro! Para plantar, tinha que ser no ponto que o Adelmo levou ele, onde ele morava. Lá já dá milho, arroz, mandioca. Tem que ser morro. Cana e feijão. Café também dá. Daqui até esse ponto deve dar um quilometro e meio, nessa direção.

$\boldsymbol{D}$ - É muito rio e não tem mais nada, tem que passar pela água.

A - A única coisa que eles liberaram para gente passar foi a trilha aberta do encanamento da água para chegar na cachoeira. Dá uns dois quilômetros daqui até lá.

D - É para limpar a cachoeira.

A - Ficou conversado e liberaram para ficar aberta.

$\boldsymbol{D}$ - Tem que limpar os canos para não tampar. Dois quilômetros é longe. Tem que sair cedo daqui para chegar lá. A Talita nunca foi lá. A primeira mulher de Nivaldo também não foi, quem foi, foi à primeira mulher do Elizeu, menininha triste ela, deu conta de ir! Lá nós plantávamos de tudo! De tudo! Eu criei os meus filhos lá porque a terra aqui não era boa. Plantava horta não dava, plantava bastante coisa e aqui não dava. Então nós mudamos lá para cima. Ele cerrou madeira e fez uma casa e lá eu plantava, criava galinha. Aqui não dava para criar porque os vizinhos eram aqui, o outro ali, e as minhas galinhas iam tudo na casa das vizinhas, não dava! Elas entravam pelo mato aqui e saía na casa do seu João Cordeiro. Morava a dona Eva aqui, o seu João ali, a escola era ali... daqui a pouco vinha recado para eu ir lá buscar as galinhas. E ia buscar que jeito? Eu buscava e daqui a pouco elas iam de novo! Depois que a mulher dele morreu, o seu João foi embora.

Nivaldo - Quem vê esse lugar agora nem sabe....

D - Mudei lá para cima, criei bastante galinha, pato, plantava horta, tinha de tudo. Esse daí criava pato. Os patos dele voavam e iam embora! Ele criava pato, criava galinha.

Nivaldo - Ali era bom para vir para a escola, era longe!

Dirce - Ele se escondia para não ir para a escola! Eu vim embora para cá por causa dele! Arrumava tudo, as meias no pé, o tênis, todo mundo passava um rio que tinha e ele falava: eu não vou passar, eu não vou, eu não vou molhar meu pé, não vou tirar o meu tênis! Os outros todos tiravam, passavam e depois secava o pé. E eu falava então venha, eu levo você no "canguto" e ele falava: não, eu não vou e sentava lá e ficava! Os outros vinham para a escola e ele ficava sentado na beira do rio.

Eu tive que mudar para cá. Ele entrou na escola com seis anos, passou para primeira, segunda, terceira, quarta. Quando ele estava com dez anos ele saiu da escola, não repetiu um ano.

Talita - É porque não tinha mais escola, só ia até dez anos aqui só. Depois tinha que ir para Cananeia.

D - Depois todo mundo ia para a escola e ele ficava chorando, ele queria tomar merenda! E eu falava pra ele: você aprendeu muito rápido agora não tem aula para você!!

Nivaldo - Eu ainda voltei para a escola! 
D - Voltou. Depois a professora aceitou ele de volta. Agora você vê, a gente criou dez filhos, morando com a gente, tudo rodeado, morava uma com a gente aqui, outro lá... Mas depois saiu todo mundo, vai embora, fica só a gente...

"Tirou a liberdade do povo, porque as pessoas andavam o sítio inteiro, agora já tem certa parte em que ela não pode ir. Dentro da RDS tem que trabalhar, mas tem que trabalhar no plano de manejo e não pode quase nada."

Dona Dirce

$\boldsymbol{A}$ - Depois que saiu essa reserva, que o seu Osmar veio para cá, a única coisa que melhorou foi a polícia ambiental, porque eles não deixavam a gente trabalhar. A gente encostava no mangue para tirar a ostra, eles falavam: vem aqui, vou levar o barco! Corre, vem aqui eu vou levar o barco porque está abandonado. A gente tinha que correr, deixava de tirar a ostra para ver o barco... Mas isso era só encostar no mangue que pronto, eles já estavam lá. Agora não e nesse sentido melhorou para caramba. Acho que o Osmar conversou com eles. A gente chegava lá e falava: poxa a gente mora aqui! Ah mas a gente não viu! Como isso se passa todos os dias e vê a gente aqui? Porque no resto não melhorou mais nada! O que sobrou para gente foi essa área de pesca. Nasci aqui e acho que vai ser aqui até a morte. A vontade é essa. Mas você sabe que tem as caídas para o caminho. No caso dessa RDS, para nós foi uma coisa muito ruim...foi ruim mesmo. Já está tirando a nossa tradição.

$\boldsymbol{D}$ - Tirou a liberdade do povo, porque as pessoas andavam o sítio inteiro, agora já tem certa parte que a pessoa não pode ir. Dentro da RDS tem que trabalhar, mas tem que trabalhar no plano de manejo e não pode quase nada. Se for para cortar uma árvore tem que pedir ordem, para fazer um remo tem que pedir ordem, para cortar madeira para fazer viveiro tem que pedir ordem e até a ordem vir... Para a gente fica difícil. Para nós que já somos de idade, a gente entende que a lei muda mesmo, mas para os filhos que são jovens e não são amadurecidos, para eles é muito difícil entender. E por isso que eles saem e vão embora. Porque nós temos paciência de pedir. Hoje quando se pede uma madeira é um ano para vir a ordem. Nós temos paciência de esperar, mas os filhos já não têm. E foi o que aconteceu aqui, os filhos foram saindo, indo embora, não dava nem para fazer uma canoa. O meu filho, o Eliseu, que está lá fora agora, ele mexia com canoa, precisava de dinheiro fazia uma canoa, vendia. Agora não dá mais para isso. Era canoeiro que era uma maravilha e deixou tudo, pegou, saiu e foi embora. Ele fazia cada canoa que até um cara de São Paulo veio aqui filmar para levar. Ele fazia cada coisa linda, ele era canoeiro mesmo. Ele trabalhava também com artesanato, fazia barquinho, fazia de tudo.

A - Fazia bem e gostava de artesanato. Mas não teve jeito. A gente fica pensando...

D - É. Quando ele saiu daqui para nós foi uma derrota porque ele morava com a gente. Até na hora pensei em ir embora junto, mas até agora estou aqui e não sei o que vou resolver. Os filhos moram com a gente e depois vão embora a gente não acostuma, sente falta. Eu sinto falta, eles moravam todos comigo e fiquei sozinha. Eu fico aqui por causa do Nivaldo que está aqui, porque a gente não quer abandonar ele, deixar ele sozinho. Ele tem a nenezinha, não dá para deixar, mas que é difícil é difícil a vida. Dez. filhos... começando pelo mais velho é o Claudio, Maria Rosa, depois vem o Adelmo, Rosilda, Antônio, Elizete e Elizeu que são gêmeos, depois o Valdeci que está em Registro 
e o Nivaldo que é vizinho daqui. Só um que mora em Registro, os outros estão tudo em Cananéia.

Um trabalha na Miami máquina de gelo, o outro trabalha numa fábrica de bloco em Registro, o Valdeci. Estão por aí encaminhado. O Eliseu foi embora não faz seis meses.

$\boldsymbol{A}$ - Cinco meses acho que ele foi embora. O Valdeci faz nove anos que foi embora, o Claudio faz uns quinze, a Rosa faz uns dezesseis anos. A Rosa saiu porque casou e foi embora, agora o resto saiu. Casou com o João. O João é do Bom Bicho.

D - Ninguém mais quer plantar. Por que quer terra então? Nisso é melhor hoje, porque o que aconteceu aqui de problemas foi por causa de grileiro de terra mesmo. Porque todo morador que entrava aqui fazia um barraco e queria vender. O Joao vendeu, seu Antônio Cordeiro vendeu, seu José Godoy vendeu, e o Wilson fez uma ali e começou a ir não sei aonde e oferecer para vender. Imagine! Tudo morador daqui! Quando foi um dia, eu estava em casa sozinha, veio tal de um oficial de justiça, bateu palma, eu fui ver e ele falou assim: aqui que mora o Davi? Eu pensei Armando Davi Pereira, eu disse: sim, é esse mesmo. Ele disse: eu vim aqui porque ofereceram essa terra, essa área mesmo aqui para umas pessoas, para vender isso daqui. Eles estão querendo dar um golpe no Estado, estão querendo pagar para as pessoas irem embora. Como já tinha acontecido muitas brigas com o grileiro eu falei: olha, eu não tenho nada com isso, eu moro aqui mas vou trazer o documento, o mapa. Eu trouxe, ele pegou o mapa e falou: nossa isso daqui me ajuda muito, as pessoas que estão querendo vender isso daqui estão com um documento frio, é um documento que não vai valer nada. E foi por causa dessas vendas que o Estado viu que eles iam vender tudo por um dinheirão, uma terra grande. Eles desmatavam e acabavam com tudo. Então pegaram e fizeram o parque porque com o Estado ninguém pode mexer né? Foi um tempo atrás, faz pouco tempo. Não faz três anos que apareceu esse oficial de justiça e depois eu fui chamada no Fórum, chamaram o José Godoy.

$\boldsymbol{A}$ - Nós temos toda a papelada aí da Sulcar. Tenho. Amanhã tem que procurar né? Era audiência de desapropriação. É uma firma muito rica!

$\boldsymbol{D}$ - Isso e tinha o nome do homem guardado, do oficial de justiça. Está escrito ali no papel! Ele ainda bateu nas minhas costas e falou: não fica com medo que nós vamos te ajudar!

$\boldsymbol{A}$ - E ele esteve nessa audiência, tem o nome dele ali.

D - É a mesma empresa da época em que nós fomos ameaçados. Faz tempo... faz uns vinte e seis anos, porque quando aconteceu isso eu estava grávida dos gêmeos. Até que eu desmaiei porque eles quebraram tudo as canoas que estavam no porto. Os grileiros vieram aqui e quebraram tudo, tudo, não deixaram nada! Armando chegou aqui e disse: o que foi aquilo com as minhas canoas no porto? Ele bateu com o pé na porta nervoso, e eu falei: o que foi que está acontecendo? E ele me contou que quebraram todas as canoas, cortaram todas as minhas redes. Eu estava grávida e ele chegou do serviço de pescaria, pegou um facão e falou: quem eu encontrar pelo caminho eu vou matar! E eu só lembro que eu grudei na camisa dele e falei para ele: não vá! Ele saiu de lá de cima e veio para cá e eu saí grudada na camisa dele e ele me jogava pra lá e pra cá e eu grudava de novo. Eu vim com ele e encontramos com o seu Antônio Cordeiro e ele falou assim: Armando não faça isso, você tem os seus filhos para criar, a sua mulher está gravida, não faça isso. Passou três dias eu fui para o hospital, passei mal. O padre João veio, me ajudou, me apoiava muito sabe? Eu fui no médico e ele foi ver se eu estava bem, ele sempre nos apoiava. Foi uma luta, nós ficamos sem uma canoa, cortaram todas, as grandes e tudo. Depois ficou assim, eles faziam festa aqui nesse campo, traziam aquelas baterias grandonas de caminhão para fazer a festa, soltavam fogos, dançavam no campo 
e quando a gente fingia que estava dormindo eles vinham para queimar aqui. A gente não dormia. Depois eles cercaram tudo de arame farpado.

$\boldsymbol{A}$ - Eles eram daqui da Cananéia. O verdadeiro capanga era o Edimilson Baiano.

D - Casado com a Durva.

Talita - Aquele moreno que tem o caminhão? Sério? Meu senhor! Ele fez isso?

Nivaldo - Não, ele era contratado pela firma, entendeu?

Talita - Então mas o meu pai trabalhou há poucos anos para ele, e eu não sabia que ele fez isso. Pensei que era de fora, de São Paulo.

Nivaldo - Mas era o serviço dele.

$\boldsymbol{D}$ - Ele cercou tudo, eu ia andar e levar as meninas para escola, porque nós morávamos lá em cima, e o meu marido falava: cuidado para levar as crianças pra escola porque no caminho está perigoso. Eu vinha trazer as crianças e voltava. Num dia que eu fui levar o caminho estava todo cercado de arame farpado, cada madeirona fincada na terra, tudo cercado e eu pensava: e agora? Por onde eu passo para levar as crianças para escola? Então eu pisava no arame, com a outra mão eu abria para cima o arame e ia enfiando as crianças pelo vão assim. Rozilda, Claudia, o Adelmo. O mais fortinho pulava por cima e depois eles faziam o mesmo para mim e passava de quatro pés por baixo do arame para trazer eles da escola. Cheguei em casa e contei para ele, falei pra ele que os caminhos estavam todos cercados de arame farpado. Que não tinha mais como e que ia acontecer alguma coisa para as crianças. Seu Antônio que tinha roça, trabalhava junto com nós para lá falou: ah não pode ficar assim, vamos no Fórum. Vamos lá ver o que vai acontecer com a gente, eu não posso ir na roça pegar as mandiocas, os carás, não posso pegar porque tem cerca no caminho? Foi o Armando, o Gentil, o Jose Godoy e o Antônio Cordeiro, os quatro, eles foram pro Fórum. Seu Orlando do Fórum é vivo, o oficial. Aí vieram quatro policiais, eu lembro que eles vieram com alicate e chegaram no arame farpado do caminho tinham três caras trabalhando e eles falaram: peguem isso e sumam daqui, deixem os moradores em paz, porque se vocês não levarem todo esse arame farpado embora agora vocês irão embora no nosso barco. Se vocês não levarem eu vou levar vocês todos algemados, obedeçam. Eles cortaram tudo e levaram o arame embora pra Cananéia no barco deles. E eu conheço todos eles. Passou dois dias mandaram mais uns oficiais de justiça com uns dez alicates e fui eu, as minhas irmãs, o Armando, os meninos que já eram grandes cada um com um alicate cortando cerca de arame farpado.

$\boldsymbol{A}$ - Nós derrubamos mais de meio metro de picada de arame farpado.

$\boldsymbol{D}$ - De noite, com uma lanterna a gente ia cortar arame farpado. A gente trabalhava durante o dia e a noite ia cortar arame farpado, tem até hoje ainda. Até hoje você acha, enrolado nas árvores. Foi uma luta porque eles falavam que a gente ia preso porque estava cortando arame farpado, mas era ordem do juiz. E ficamos oito anos brigando no Fórum.

$\boldsymbol{A}$ - Oito anos indo em audiência. O padre João e o advogado era o Teleginsk. É, ele era advogado, delegado e conselheiro do meio ambiente. Era esse que eu falei que estava em depressão. Os jagunços destrincharam todo a canoa em pedacinhos, mas ele juntou todos levaram e fizeram a canoa de novo! Ele falou tudo que você achar você me traz! E eu juntei porque estava tudo amontoado lá. Fez a canoa de novo! Levou e trouxe boazinha a canoa outra vez. Não deu nem coragem mais de usar.

$\boldsymbol{D}$ - Três canoas quebradas. Nós sofremos muito aqui. Os meus meninos foram crescendo com aquele trauma dentro deles, e o padre falou para mim: os seus filhos vão crescer revoltados porque eles já eram grandes e já entediam as coisas, e eles guardaram essa mágoa dentro deles. E pior que eles não podiam ver essa gente, quando eles viam eles queriam pular, queriam brigar. Eles não podiam ver essas pessoas que fizeram isso 
com a gente. Continuaram convivendo perto mas não podiam se ver, cada vez que se viam eles discutiam. Aqui mesmo, porque os caras não saiam daqui. Ficaram nos oito anos. O dono daqui mesmo que fez isso, o seu Durvalino com o seu Gilmar que venderam e o cunhado dele, então eles não saíram daqui, moravam aqui mesmo, ficaram de caseiro tomando conta. Eles ficaram tomando conta do sítio ainda.

$\boldsymbol{A}$ - Eles venderam tudo! Eles venderam a área toda. O lote do Taquari ali eles entraram lá pelo seu Alfredo e vieram de lá para cá, cortando, loteando. E vendendo. Cortando, fazendo picado, tudo em lote assim, eles fizeram um xadrez na área inteira. Eles já estavam aqui perto de casa.

D - Diz que a cerca de arame era para pôr búfalo né? Eles iriam entrar pelo Taquari, trazer os bichos e soltar aqui, e pior que nós tínhamos a nossa casa e ficou tudo para dentro. Quando eles lotearam a terra lá nos fundos, entraram tudo pelo Taquari, pela estrada. Os trabalhadores eles mandaram tudo por ali, quando nós ficamos sabendo já estava tudo loteado.

A - Daqui até o Taquari, até o Alfredo, dá uns seis quilômetros. Depois desses seis quilômetros tem mais um quilometro que chega na estrada. Abrindo picada eles chegaram ali no sítio do Alfredo. E eles fizeram tudo por lá. Dá para ir pela área do Alfredo Sens, lá do Taquari, que pega lá perto do Ariri, ficava tudo esse fundo. Ele tinha uma picada grande lá no fundo que era divisa do sítio dele. $O$ nosso sítio fazia divisa com o dele. Para cá era nosso aqui para lá era dele, do Alfredo Sens. Eu não sei o que aconteceu com aquele homem.

$\boldsymbol{D}$ - Dali do dele, de lá para cá, ele nunca entrou aqui.

$\boldsymbol{A}$ - Ele tinha jagunço, tinha tudo ali. Eles traziam porque não queriam que ninguém entrasse né?

$\boldsymbol{D}$ - Para cá era só ele que tinha jagunço.

A - Lá do Taquari até o Ariri era jagunço direto, vinha lá de Ponta Grossa lá do Paraná, aqueles caras perigosos, eles atiravam até na sombra da pessoa.

$\boldsymbol{D}$ - Para ninguém entrar! Para não cortar palmito, caçar...

$\boldsymbol{A}$ - É, porque a turma do Taquari, a vivência deles era palmito, então eles colocaram jagunço para ninguém entrar para cortar o dele. E era tudo grilado.

$\boldsymbol{D}$ - Eles eram tudo grileiro, foi esse que ia atirar no padre João?

A - Não, era jagunço de outro cara lá do Ariri.

D- O Padre João fazia festa de batizado, fazia missa....

A - Ele fazia do Varadouro, Barra do Ararapira, Marujá, vinha vindo em todas essas comunidades, todas ele visitava. Sozinho. De barco, sozinho.

$\boldsymbol{D}$ - Era uma voadeira dele, ele vinha às vezes com visita, com estudante, quantas vezes, aquele padre Ari, Arenildo.

$\boldsymbol{A}$ - Agora ele é padre em Pariquera né?

D - Ele conta a historinha toda daqui. Esses dias eu estava internada em Pariquera e eu encontrei com ele. Perguntou daqui tudo, ele não saía daqui de casa com o padre João. É em Pariquera ou Registro? Ele prometeu que vinha aqui e não veio!

$\boldsymbol{A}$ - Pariquera. Ele tocava um violão que meu senhor!

D - Era amigo do Padre João se informa com a Cida ${ }^{200}$ que ela conta para você. A Cida sabe toda a história, ela cantava hino na igreja. Eu sei o hino que ela cantava, eu nunca esqueci.

"Vem vamos embora que esperar não é saber, quem espera vê a hora e não espera acontecer.” Ela ia embora cantando esse hino para lá.

\footnotetext{
${ }^{200}$ Acompanhava Padre João e colaborava com a Igreja local.
} 
Eu estava grávida do Elizeu com a Elizete que hoje estão com vinte e seis anos. Um dia eu ouvi, porque antes de começar a briga, aqui era tudo aberto o caminho dos vizinhos, era caminho de ir para roça, aqui era a roça e ali o caminho. Tudo que se falava aqui dava para ouvir e a gente via uns homens diferentes de idade passar, com inchada e um pouco de terra. Eles moravam tudo aqui ainda! Eu escutei eles falarem que aqui nessa terra, aqui nesse sitio tem ouro, tem mina, tem ouro. Um falava para o outro e o seu João falava nesse sol quente tem ouro até para os galhos da madeira ele falava! Aí o outro falava assim, é, mas vinte e cinco mil nós damos para o senhor de entrada e o resto nós vamos pagando aos poucos... Eu pensei: ah venderam mesmo!

Não, nós sabemos por quanto eles venderam. Eu sei que eles fizeram casa na cidade, o Edimilson fez casa para o sogro. Eu falei para o padre Joao um dia que ele estava falando de terra, de Ilha do Cardoso que o Retiro ${ }^{201}$ estava vendido. Ele perguntou: como assim vendido? Eu disse que eu escutei uma conversa, eu estava na roça tirando mandioca e passaram uns homens esquisitos falando a quantidade de dinheiro que tinham dado para o seu Edimilson, genro de seu João. Aí ele tentou descobrir e foi para todos os cartórios e achou. Achou que o seu João deu para o genro fazer dele o que ele quisesse. O Edmilson que fazia tudo isso e morava com a mulher dele. Ele casou uma moça daqui, entrou e começou a fazer as coisas aqui. Para ajudar ele trazia mais gente lá da cidade.

A - Juntava o povo daqui mesmo, um povo de lá, ou do Bombicho ${ }^{202}$, uma rapaziada. Ficava ai nesse campo com um som que era uma barbaridade.

A - Na declaração que ele passou no cartório de Cananéia a mulher dele assinou e ele também, dizendo que o genro poderia fazer o que ele quisesse, pode vender, dar, trocar com qualquer coisa que você quiser. Não sei por que quem estava com esse papel era o advogado. Mas o Teleginski esteve aqui em casa que hoje mora em Santo André. Ah deve ter sim, a Cida também sabe bem dele. Antônio Teleginski, deve ter naquele processo ali.

D - Não tem naquele papel verdinho? Depois dessa briga nós ganhamos a reintegração de posse que foi mandado pela juíza, eu tenho guardado. Depois disso, eles foram embora mas a casa está aí ainda, de vez em quando eles vêm, roçam.

$\boldsymbol{A}$ - É ali no Porto a casa que eles construíram. Não tem o bambu ali no porto? Aquele lugar que eles vendem máquina de roçar ali, eles roçam ali.

$\boldsymbol{D}$ - Dá é tudo pertinho. Amanhã a gente vai lá, uma casa de material velha.

$\boldsymbol{A}$ - O projeto dele era fazer vinte e cinco casas aqui, mas fizeram só aquela ali.

$\boldsymbol{D}$ - Eles iam vender pra essa gente bem de vida e iam fazer essas casas aí.

$\boldsymbol{A}$ - E eles deram dinheiro do Edmilson para ele tirar o resto dos poceiros que estavam aqui. Para expulsar. Por isso que ele fazia essa pressão.

$\boldsymbol{D}$ - Ele fazia essa bagunça nas coisas da gente pra gente desanimar e ir embora.

$\boldsymbol{A}$ - Quebrou todas as minhas canoas, cortou todas as minhas redes para a gente ir embora.

$\boldsymbol{A}$ - Não é deles, eu conheço o cara que fez essa casa, ele ficou de caseiro aí uns quatro anos ainda... O Durvalino que agora está na Ilha do Cardoso morando no parque.

$\boldsymbol{D}$ - Ele mora no parque agora.

A - Foi o pai dele que enganou o Marcos Campolim, no tempo que o Marcos Campolim era diretor no parque da Ilha do Cardoso. O Marcos Campolim deu uma ordem por escrito que ele podia morar lá. Ele fez toda essa bagunça aqui, vendeu e foi embora para lá. Ele ficou muitos anos aqui. Carteira assinada, ele ganhava salário todo

${ }^{201}$ Nome de um dos bairros que compõe e RDS Itapanhapima.

202 Outro bairro que compõe a RDS Itapanhapima. 
mês. Nasceu aqui, a mãe dele e o pai dele todos nasceram aqui e fizeram esse papelão. Num sitio chamado Barreiro, é quase em frente do Trolado.

$\boldsymbol{D}$ - É então... e disseram que agora entrou um bocado de gente para serrar madeira e eles estavam desmatando tudo. Eu soube mais ou menos, eu não sei se é verdade, eu não sei se são eles que moram lá mesmo que fazem.

D - Nós saímos daqui e fomos lá para cima. Não dava para dormir, as crianças choravam assustadas com o barulho, os fogos... Daí nos mudamos lá para cima. Tinha muita bebida. Tinha medo de que eles fizessem alguma coisa pra gente, matasse as crianças tudo queimado, as crianças eram pequenas. A gente cansada do serviço da roça, dormia. Era a hora que eles queriam. A gente tinha um cachorro que era bravinho, não parava de latir com a barulheira. Quando passava barco no porto, ele estava sentado, escutava o barco, se não fosse o barco do Armando ele não ia para o porto, mas latia avisando. Eu não sei como que ele sabe quando é o barco do Armando, quando era o barco do Armando ele vai para o porto. Não vai, eu já vi, pode ser quem for, ele não vai.

$\boldsymbol{A}$ - Esses dias a gente foi pra Cananéia e ficamos cinco dias, e deixamos ele aqui, quando a gente chegou ele estava lá na barra do rio esperando a gente nadando. Eu não sei como ele conhece o barulho do motor! Nessa época da briga cada vez que o padre João vinha, trazia, lá do Itacuruçá ${ }^{203}$ e do Ariri ${ }^{204}$ um monte de gente.

$\boldsymbol{D}$ - Saía de domingo daqui dois, três barcos de pessoas que ficavam com a gente. $O$ Padre João aconselhava a não fazer violência, a não ferir ninguém. $O$ meu cunhado pegou uma arma e quase matou um. Ele veio aconselhar, e ele pediu para não fazer violência porque se não tudo ia ficar pior, ele vinha aconselhar, vinha o José Carlos, aquele Adenil, vinha toda a turma do Perequê.

$\boldsymbol{A}$ - Itacuruçá, Perequê, Pereirinha, é tudo uma coisa só.

$\boldsymbol{D}$ - Ficavam a semana inteira aqui. Foi muito boa aquela gente para nós. Eles ajudaram bastante a gente. Tudo graças ao padre João.

D - Quando quebraram nossas canoas, deixaram a gente sem nada. Se não fosse o padre João vir aqui para nos socorrer, íamos morrer de fome, porque não tinha como sair para pescar. O padre Joao pegou os pedaços da canoa, compraram cola, levaram para Cananeia, colaram. O Jorge com o Zé Carlos do Pereirinha, que é o meu compadre, ele é padrinho do Nivaldo, eles vieram trazer a canoa que dava pra gente pescar. Finado Jorge morreu na agua.

$\boldsymbol{A}$ - O Zé Carlos. Ele tem pousada ali na Trincheira ${ }^{205}$. Não tem a Golfinha lá do outro lado? Para cá do parque 206 um pouquinho, na ponta do morro, não tem o porto que encosta barco ali? Ali é a Golfinha. Eu acho que até um pouco vai de carro. Atravessa a balsa para a Ilha Comprida e tem uma entrada que até ali vai, depois eu não sei se tem caminho. Isso é bem perto da Boca da Barra. Ali é Rio Verde que fala não é? Só que fica do lado de cá, do Lagamar, não do lado do mar. Aquele pessoal... Meu deus do céu. Eles ajudaram muito. Gente muito boa aquele povo ali.

D - Eles ficavam com a gente, ajudava o povo, dava força, dava conselho, porque o povo estava revoltado e ainda era capaz de fazer uma besteira e ir preso, pronto!

O Padre João visitava todas essas comunidades. Só aqui no Retiro morava vinte famílias. Eu ia para a reunião paroquial duas vezes por mês, eu trabalhava com o padre Joao na catequese. Eu dava aula de catecismo para a criançada daqui. Tinha que ir

\footnotetext{
${ }^{203}$ Comunidade ao norte da Ilha do Cardoso.

${ }^{204}$ Bairro de Cananeia continental

205 Ilha Comprida.

${ }^{206}$ Fundação Florestal. É comum os moradores se referirem à Fundação Florestal como o "parque", o lugar da instituição. E seus funcionários como o "pessoal do parque".
} 
duas vezes para reunião na cidade, andávamos por tudo, ia pra Registro, ia apresentar os trabalhos que eu fazia e levava todo mundo comigo! Tudo de canoa.

Ia todo mundo e o padre Joao fazia aquela grande festa, fazia aqueles bolos e mostrava: aqui ó, aqui está o presente de vocês! Colocava na mesa e cortava! E chamava todos eles para tomar café, suco e comer bolo! Eu nunca deixei de ir pra reunião!

o padre João dava um livro, uma caneta pra cada um e mandava todo mundo pra uma sala para desenhar.

A- Ele se esforçava e tinha que ir. Ele falava que tinha que se esforçar e ir.

D - Ele falava assim: hoje vocês vão desenhar a sua casa, o seu sítio, o seu porto, as suas canoas. Cada um ia fazer um trabalho para ir lá mostrar e depois ganhava o desenho mais bonito e quem ganhava mais era a Rosilda, eles ficavam danados da vida com ela!

A - Iam todas a comunidades... Do Taquari, Ariri, do Varadouro, do Marujá.

D - As meninas daqui, dali, da outra casa. Tinha vez que iam setenta, oitenta pessoas.

A- Ia até o pessoal de Pedrinhas ${ }^{207}$ na reunião. É, Pedrinhas é perto de Iguape, ele participava direto das reuniões.

D - Ia de Porto de Cubatão ${ }^{208}$, Mandira ${ }^{209}$, de cada lugar ia um pouco.

"É uma coisa muito importante. Eu lembro quando o meu pai fazia mutirão a turma bebia dia e noite e quando eles se despediam de manhã do mutirão do fandango, se despediam chorando acredita?"

Armando

D - Quando eu vim para cá tinha muita gente.

A - Muita gente. Tinha campo de futebol, a turma jogava lá pra Marujá, Vila Fatima, Ariri, saiam para todo canto jogar. Tinha time bom aqui!

$\boldsymbol{D}$ - Mutirão tinha direto! Trabalhavam durante o dia, se era derrubada, e de noite o povo se reunia tudo para dançar forró. Quando era de plantação de rama iam os homens e as mulheradas plantar. Rama é essa mandioca de fazer farinha, você corta tudo em pedacinho para pôr nas covas que eles cavavam. Todo mundo comia, fazia almoço, janta... mas falando em comida, vamos almoçar né?

$\boldsymbol{A}$ - É uma coisa muito importante. Eu lembro quando o meu pai fazia mutirão a turma bebia dia e noite e quando eles se despediam de manhã do mutirão do fandango, se despediam chorando acredita?

D - Era tanta gente né?

$\boldsymbol{A}$ - É, eles se despediam chorando, eles pegavam na mão chorando!

$\boldsymbol{D}$ - É, porque às vezes vinha gente de longe!

$\boldsymbol{A}$ - Eles bebiam a noite inteira. Sabe o que é beber engradado de bebida que ficava assim no canto.

D - E ninguém brigava, todo mundo dançava...

$\boldsymbol{A}$ - Não tinha um enguiço. E ninguém brigava! Não tinha briga, nada! Hoje se você fizer um churrasco para assar uma carne, não passa nem duas horas eles já estão brigando!

\footnotetext{
${ }^{207}$ Praia situado no município de Ilha Comprida.

${ }^{208}$ Bairro de Cananeia continental.

${ }^{209}$ Bairro de Cananeia continental hoje reconhecido como comunidade quilombola e reserva extrativista (RESEX)
} 
D - Mas agora já mudou bastante, está melhor. Até em Cananéia que era muito violento já está mais maneirado. mesmo?

$\boldsymbol{A}$ - Ia a noite inteira. Você já escutou o fandango mesmo? Fandango legítimo

Do Zé Pereira, do Leonildo Pereira que é meu primo. O Baduca também era do grupo. Ah o povo fica até tarde!

D - E bebe. Nossa, o Zé Pereira (...). O Leonildo é filho de quem?

$\boldsymbol{A}$ - Ele é aquele do pezinho torto não é?

D - Mas aquele não morreu?

A - Não.

D - Armando também tocava bem. Um garrafão de pinga era pouco e uma viola. Todos os fandangos que tinha, eles vinham aqui chamar porque era ele que tocava! Mas bebia uma pinga! Tocava viola a noite inteira, mas também quando tirava para beber nossa senhora!

$\boldsymbol{A}$ - Eu bebia demais, meu senhor! Eu nem quero lembrar disso!

D - Era cada garrafão! Às vezes não, mas às vezes quando saía do forró, ai, ai, ai! Mas ele não brigava em casa não! e deitava.

$\boldsymbol{A}$ - Ah não, dentro de casa eu nunca quebrei um copo em casa, eu chegava bêbado

D - Quando ele estava bêbado, chegava, deitava e dormia até! Depois quando ele levantava com ressaca ele falava que estava doente, porque ele sabia que eu não ia cortar limão para fazer cura para ele da ressaca. As crianças falavam: o papai tá ruim? Eu falava está ruim da ressaca! E eu falava: ah não vou, se fosse doença eu ia! (Risos)! A ressaca deixa ruim né?

$\boldsymbol{A}$ - Eu não quero lembrar desse tempo não!

D - As crianças tiravam um sarro dele quando ele estava bêbado, ele chorava que estava ruim! O Fabio era trocista, farrista! Ele falava: ai eu estou doente, não consigo nem levantar! E o Fábio ria e falava: ah o papai está doente por causa de um garrafão e dava risada! Ele tirava sarro! acredita?

$A$ - Uma vez nós tomamos vinte e cinco litros de vinho em duas pessoas você

D - Era festa. Batizamos nove crianças nesse dia.

A - Vinte e cinco litros de vinho! Meu Deus!

Talita - Não sentia dor na cabeça no outro dia?

D - Vinha padre João, veio toda a turma do Pereirinha em peso, veio um estudante que estava trabalhando com o padre Joao que estava se formando para padre, uma coisa assim. Eles vieram para essa festa de aniversário e nós batizamos nove crianças. O Elizeu tinha esse tamanho quando batizou, era bem grande. Batizou, o casal. O Elizeu com a Elizete, Irani de São Paulo Bagre ${ }^{210}$ foi à madrinha de Elizete, seu Zé Godoy foi padrinho do filho do Gentil. Veio mais gente de Cananeia. O Benedito com a mulher foi padrinho e a madrinha do Elizeu. O nosso batizou o casal de gêmeos e o deles batizou parece que mais uns oito, eu sei que foi nove ao todo. Terminou a festa era umas quatro horas da tarde, teve almoço, teve lanche. O padre João ajudou a gente, fizemos lanche para a criançada. Eu, a Bete e a Katia lá do Pereirinha fizemos o almoço.

Talita - Foi lá na cidade?

D - Que na cidade, foi aqui menina! Nós tínhamos uma casa de madeira cercada.

Talita - Então se batizaram em casa?

${ }^{210}$ Bairro de Cananeia continental. 
D - Não, se batizaram na igreja. Tinha Igreja. Tinha uma capelinha de madeira! É o que tempo já destruiu, apodreceu tudo as madeiras, cupim comeu tudo. Quando deu quatro horas o padre João foi embora, quatro barcos carregados de gente. E Armando junto com o meu cunhado, marido da minha irmã, ficaram bebendo esse vinho até não sei que horas da madrugada, acabaram com o resto. Nós fomos embora e eles ficaram. Tocavam viola e bebiam, os dois sozinhos! (Risos)

$\boldsymbol{A}$ - Bebida demais no cotidiano atrapalha, não pode! Atrapalha a cabeça e as próprias pessoas que você convida para beber com você, vai enguiçando. Não sabe mais o que está fazendo. Perde a mente e não sabe o que faz.

$\boldsymbol{D}$ - Dessa vez ficou três dias de cama!

$\boldsymbol{A}$ - Mas eu bebia mais quando eu me juntava com a turma, não era sempre.

$\boldsymbol{D}$ - Sabe aqueles garrafões? Eram uns garrafões de vidro.

$\boldsymbol{A}$ - Hoje em dia não bebo nada, de jeito nenhum.

D - É que ele ficou doente. Depois que ele ficou doente levou um susto e não bebeu mais. Fiquei dezesseis dias aqui sozinha com a criançada.

$\boldsymbol{A}$ - O padre João também bebia. Era um litro de cinquenta e um na hora do almoço, depois ele destampava outro, bebia até a metade e ia embora.

$\boldsymbol{A}$ - Meio litro e um copo grande que ele tinha de bebida, ele colocava na boca e virava como se fosse uma mangueira.

Talita - Ele bebia o padre João?

D - Claro! Bebia!

Talita - Nossa mas ele não era padre?

$D$ - Padre não bebe?

$\boldsymbol{A}$ - O padre bebe mais que ... bebe pinga pura e tudo...

D - Nossa ele bebia as caipirinhas, bebia tudo!

A - Ele bebia tudo!

Talita - Ele morreu por causa disso?

$\boldsymbol{A}$ - Ele não ia no bar beber, mas quando ele ia nas comunidades ele bebia. Bebia de ficar bêbado mesmo.

$\boldsymbol{D}$ - Ele morreu porque ele tinha diabetes e câncer em uma perna porque uma moto bateu nele, deu uma hérnia ele operou mas ele não resistiu à cirurgia.

Talita - Conheci. Ele era bonzinho, ele ajudava muita gente ali em Cananéia, principalmente ali na pastoral da criança.

D- A Cida era a companheira que andava com ele para baixo e para cima.

D- Eu gosto muito da Cida, meu Deus onde ela me vê ela cumprimenta e quer tirar foto minha e fala: não se esquece de mim! Acho que até hoje ela não me esqueceu!

$\boldsymbol{A}$ - Ela é muito boa gente, para conversar!

D - Às vezes eu vou a reunião de pesca, vou almoçar e ela corre para pegar a máquina para tirar foto! Ela fala que depois que o padre João morreu ela perdeu todas as fotos.

$\boldsymbol{A}$ - Eu acho que ela guardou as coisas gravadas que o padre fazia. Eu não sei se ela ficou com a casa dele, porque acho que quando ele morreu foi ela que ficou com a casa dele.

D- Não, ela mora ali naquela casa amarela ali no Carijo.

A- Mas então é a casa do padre João.

D- Não, primeiro ela ficava ali no salão paroquial.

A- Ali do lado do mercado estrela.

D - Eu sempre vejo a Cida ali. 
A - Só que não é do lado do mercado, é ali do outro lado da rua, passando o mercado estrela. É uma esquina que você entra, bem na esquina é a casa, aquela murada inteira, eu não sei se ela mora ali, mas é ali perto.

D - Aquela casa ali acho que ficou para ela, porque ela trabalhou toda vida ali e não teve nada. Então acho que ele pegou e fez uma casa.

$\boldsymbol{A}$ - É ela que cuida. Ele deve ter deixado. Ele morreu para lá, na Holanda.

$\boldsymbol{D}$ - E difícil ela não ir numa reunião da gente, de pesca ${ }^{211}$. Tem reunião da pesca, eu sempre participei, e sempre quando eu vou ela sempre está lá, eles contratam ela para ajudar. Porque tem bastante gente nas reuniões e ela conhece todo mundo. Por aqui tem tainha mas também é só em abril, maio, junho, é a época e depois acaba. Depois são os peixes miúdos, parati, robalo, carapeba, essas coisas, mas a Tainha some. No verão esses que tem bastante né?

Talita-Meu senhor, aí tem camarão, tem tudo!

D - Camarão tem em fevereiro. Está fechada a portaria ${ }^{212}$.

A - Para falar a verdade de camarão eu não sei.

D - Mas aqui a gente pega para comer só.

Talita - Está fechado porque a minha cunhada trabalha com camarão e está fechado, ela não está trabalhando.

A - Para falar a verdade a pesca, o fechamento é lá fora né?

$\boldsymbol{D}$ - Tem três tipos de camarão.

$\boldsymbol{A}$ - A pescaria de camarão aqui de dentro do rio não consta nada. Camarão rosa é só lá fora. É, aqui é só camarão branco e ferro.

$\boldsymbol{D}$ - $O$ branco é muito gostoso.

A - Pescamos na época dele, de gerival ${ }^{213}$. Só que a pescaria de gerival não consta que é pescaria. Não tem portaria de gerival! Gerival é de pescar camarão, uma rede! É a redinha que você pesca o camarão. É só você pegar a música do gerival, para quem não conhece. Só pegar uma música de um cantor lá em São Paulo Bagre você já sabe o que é, ${ }^{214}$ o Kiko, que fez a música do gerival né?

Talita - Ah eu já ouvi essa música do gerival!

$\boldsymbol{A}$ - É uma rede que você joga na água, arqueado, entravada numa vara e joga lá no fundo. Os camarões batem na cordinha e você sente. Começa a bater tic tic tic. Quando você sente que a rede está cheia, vem quatro, cinco quilos! Ele bate no pano e sobe direto para a carapuça que tem em cima.

Talita - Tipo uma bolsa.

$\boldsymbol{A}$ - Ele bate no pano e sobe. Pronto, já entrou.

Talita - Ai vai enchendo, enchendo... Você sente segurando a corda que ele está entrando, sente eles pulando lá dentro pela corda.

A-Vem quatro, cinco quilos cada carapuça que pega. Camarão o preço é de doze para quinze reais. Mas também começa a dar o camarão começa a abaixar também.

$\boldsymbol{D}$ - Eu comprei um quilo para a mãe e já estava doze, era grandão.

Talita - Só eu que como porque o Nivaldo tem alergia, quase morre de se coçar! Eu que aproveito, é só pra mim! Ele come um ou dois e dá coceira e quase morre!

\footnotetext{
${ }^{211}$ Com 906 sócios, a Colônia de Pescadores Z-9 existe desde 1929, mas foi constituída legalmente em 26 de abril de 1985 com o objetivo de organizar a classe dos pescadores artesanais e sua luta em Cananéia. http://www.redecananeia.org.br/COLONIA-DE-PESCADORES Acesso em setembro/2016.

212 Portarias do Ministério da pesca e aquicultura que controla os períodos de pesca de determinadas espécies visando assegurar a proteção sobretudo aos períodos de reprodução.

${ }^{213}$ http://www.icmbio.gov.br/cepsul/images/stories/artes_de_pesca/artesanal/arrasto/gerival.pdf Acesso em fevereiro/2017.

${ }^{214}$ Bairro continental de Cananeia.
} 
D - Ele já foi para o hospital por conta disso. É por causa de caranguejo, ele comeu e quase matou ele. Começou a sair bolinha, coçar, coçar, eu pensei que era outra coisa, e ele falava: mãe, eu estou cheio de bolinha, pelo corpo todo, no pescoço, coçava. O pai estava aqui no sitio mexendo com viveiro e eu em Cananéia porque eu levei ele para estudar mas ele não quis. Eu achava que não era nada, alguma coisa que ele pegou na roupa que estava no varal. Ele tomou banho, jantou, e quando foi uma hora da manhã ele começou a gritar que ele estava com um calor muito grande, falando que ia morrer, que estava muito quente. Quando eu levantei ele estava dessa grossura! Inchado todinho. A boca, as orelhas, tudo grande! O olho tudo fechado, tampado, taquei ele embaixo da água. Peguei uma camisa fresquinha e levei para o hospital. Aplicaram uma injeção nele, um tubão grande, quando foi meia hora ele melhorou. Quando chegou em casa ele dormiu até de manhã. Se ele estivesse no sitio acho que ele tinha morrido!

Talita - Eu também tive, e eu comi só um dedinho do caranguejo também fiquei com mesma coisa!

D - Mas sabe por que mata Talita? Estava com leite e acho que não pode, eu acho que ele estava mudando de casco.

Talita - Fica mole...você pega no casco e está mole.

D - Ele muda de casco. Igual quando fecha a pesca do caranguejo, igual agora está aberto, está tudo liberado a pesca, mas em outubro vai fechar e aí a gente não pode pegar porque está mudando o casco.

Talita - Está mole o casco, fica mole.

D - Ele troca de casco.

$\boldsymbol{A}$ - Se você pegar ele desmancha na sua mão! Aquele cai e nasce outro casco novo.

D - Quem é alérgico é capaz de morrer. A médica disse pra mim que o que mata é que incha, que estoura o pulmão da pessoa, já morreu criança assim. De formiga, essas formiguinhas mordeu uma criança e matou a criança.

Nivaldo - Bom boa noite, vou levar a nenê e vamos dormir. todos" $" 215$.

$\boldsymbol{D}$ - Acho que eles foram ver televisão um pouco... Agora aqui é "Luz para

A - O sistema antigo foi a turma da USP que trouxe. O que veio antes. Já, as primeiras placas que chegaram aqui vieram pela USP, com técnicos de lá. Faz tempo...

D - Faz vinte e oito anos ... primeiro veio só para a escola e depois que veio para escola a gente começou a correr atrás, correr atrás. Essa é de agora, da luz de agora que veio.

$\boldsymbol{A}$ - Eles fizeram uma coisa bem montada, mas o povo não contribuiu. Foi feita uma associação, foi aberta uma conta no banco e tinha que cada um contribuir para a manutenção das placas e do equipamento. Ficava no banco, o presidente recebia de todo mundo para que quando faltasse lâmpada, bateria, as coisas assim que ele pudesse comprar. Mas o povo não pagava e vai, vai.... Acabou a associação. Eu acho que aqui só tem esse equipamento antigo lá no Varadouro, parece que tem ainda. $O$ resto não deu certo porque o povo não colaborou porque eles fizeram tudo certo.

D - Acabou a bateria. O povo não se uniu. Ficamos bastante tempo sem luz.

A - Acabou a bateria e nós não tivemos como comprar outra.

D - É oitocentos reais cada bateria dessa grande, e se você compra a pequena não resolve nada.

A - Agora essa veio pelo "luz para todos". Não faz um ano que veio esse daqui.

$\boldsymbol{A}$ - Ah, não faz um ano...

${ }^{215}$ Projeto do governo federal 
D - Isso veio, nós preenchemos, eu fui na prefeitura, peguei o cartaz. Tem luz em todas as casas lá no Marujá? Diz que ficou bastante gente sem luz, eles falaram.

$\boldsymbol{D}$ - Aqui não tinha luz, não tinha nada, na primeira que veio era só essa lâmpada e bem pequena que nem aquelas ali.

$\boldsymbol{A}$ - Eram duas pequenas, fraquinha.

D - Agora que veio esse aparelho.

$\boldsymbol{A}$ - Eu usava essa lâmpada.

A - Essa bem pequenininha. Agora veio esse equipamento.

D - Todo mundo usava lampião e vela aqui.

A - Esse aqui já é do luz para todos, aonde não vai a luz da Elektro aí vai esse equipamento. e vela.

D - O primeiro gestor, o Wilde ${ }^{216}$ que veio para cá, ficava com nós e era lampião

A - Ali em Marujá eu não sei por que não tem, porque do Ariri passa a rede ali, não é? Acho que não aceitaram porque é parque.

D - Ah diz que foi né? O Ezequie ${ }^{217}$ que não quis, porque é ele que manda lá. Diz a Tati que era a minha nora que sabia que me falou que ele não queria. Porque ali diz que ali é tudo o Ezequiel, o que ele pedir vem. Porque ele é o mais velho ali e tudo que ele falar tem que todo mundo obedecer.

$\boldsymbol{A}$ - O que ele falar todo mundo pensa que é verdade... não sei porque.

$D$ - Deve ser porque se acostumaram com ele desde o começo. Se entrar uma pessoa que ele não quiser, pode fazer abaixo assinado e amanhã vai embora. Ele é muito legal, bonzinho, eu gosto dele.

$\boldsymbol{A}$ - Eu fui numa reunião com ele, esse negócio da planta e ele falou que guapuruvu não dá. Igual aqui onde a gente mora ele fala que não dá. Eu falei para ele: Você falou que não dá mas a minha mulher plantou lá no quintal, três guapiruvu que estão enormes! E eu falei eu acho que não dá porque não plantam, mas se plantar dá. Ele falou que não, guapiruvu é só no costão do morro que dá! É uma arvore que é mais usada para a canoa. Nós pedimos essas mudas, eles que não trouxeram. Não veio nada para mim, a única muda que eu pedi que veio foi a Jussara. A canoa pode ser várias madeiras.

\section{"Mas mexe Dirce! Mexe! Não tem como não mexer, a necessidade obriga o cara, eu falei para o seu Osmar: o abuso é uma coisa, mas a necessidade é outra." \\ Armando}

A - Guapiruvu, arapaçu, canela, peroba, tem tudo de madeira, a madeira que quiser tem no parque.

D - Mas as madeiras fortes de lei não pode cortar, é por lei. Nesse trecho não tem mais porque nunca teve.

$\boldsymbol{A}$ - Isso aqui é restinga, não cresce madeira assim aqui.

$\boldsymbol{D}$ - Nunca teve, aqui nunca foi cortado madeira de fazer canoa.

$\boldsymbol{A}$ - Aqui na restinga não cresce, não dá. Crescer ele cresce, mas dizem que ele não dá uma madeira bonita, não dá. Tem que ser onde é barro.

D - Isso, dali para lá tem madeira.

D - Mas se mudar aí o que você pede tem como fazer canoa aí dentro? Ah não fica!

\footnotetext{
${ }^{216}$ Primeiro gestor da Fundação Florestal cujo nome consta no Plano de uso.

${ }^{217}$ Morador do Marujá e um dos membros mais antigos e atuantes do conselho de moradores.
} 
A - Claro que fica! Guapiruvu sempre tem.

$\boldsymbol{D}$ - Ah não muda, nunca vai mudar, uma madeirinha assim a gente não pode cortar, eles já entraram, já viram a madeira, a madeira já são todas grandonas, nunca vai mudar. Eu tenho maior certeza, pode ficar quietinho, pode ficar na sua que nunca vai mudar, se você entrar daqui, daquele lugar que nós fomos pra lá, se você passar o encharque você vai ver, as madeiras são tudo dessa grossura aqui! Não tem mais madeirinha lá pra cima, só madeira dessa grossura.

$\boldsymbol{A}$ - $O$ Mario que é diretor do parque nunca aparece na reunião, eu até reclamei com o seu Osmar: esse Mario diretor do parque porque o senhor é da reserva mas e o do parque? Porque quem mora na reserva não é possível não ir mexer no parque, claro que mexe! Tem que mexer porque tem necessidade, não é porque ele quer mexer, mas não tem como!

$\boldsymbol{D}$ - Só se mexer sem ordem porque ordem não tem!

A - Mas mexe Dirce! Mexe! Não tem como não mexer, a necessidade obriga o cara, eu falei para o seu Osmar: o abuso é uma coisa, mas a necessidade é outra. Isso que nós estamos pedindo não é porque nós queremos derrubar a madeira para nada, é por necessidade. É para sobreviver. Não é para negócio, não é para nada. É para uso próprio.

D - Esse Durvalino que mora lá no Cardoso derruba sem pedir ordem para ninguém, vai com motosserra, passa a canoa, mata porco do mato, só vive de vender, $e$ se ele não fizer ele morre de fome! E quem nem Abílio lá na cidade, a geladeira dele é dois, três porcos!

A - Pois é mas ele tem que sobreviver!

D - Mas como que não pode pegar pra comer e para venda pode?

A - Eu sempre digo para eles que dizer que não pode é bom, mas chegar para o indivíduo com uma cesta básica na casa do cara e dizer que trouxe uma cesta porque ele tem necessidade, isso não acontece né? Mas dizer que não pode todo mundo diz!

$\boldsymbol{D}$ - Olha eu não como da caça do mato. Quando eu era solteira, meu pai matava Quati, Raposa que eu tinha nojo. O dia que a minha mãe fazia no almoço, eu não almoçava! Eu tinha nojo! O dia que minha mãe fazia eu falava: essa raposa pisou em toda essa comida! Eu falava, eu era criança boba, não sabia de nada! Eu não suporto! Eu não como nem que eu morra!

$\boldsymbol{A}$ - Um dia eu discuti com o Zico guarda parque. Ele disse que a Ilha do Cardoso era um parque e eu disse: você fala que é um guarda parque mas escute, o que eu entendo é que um parque é a área separada que não tem morador, é um lugar, uma reserva onde não pode morar ninguém! A ilha do Cardoso tem mais de dez comunidades, e é uma área onde não pode morar ninguém!

D - Mas se tiver um morador dentro do parque igual o Durvalino que está lá, ele nunca vai fazer um desmatamento, se ele pega para fazer uma casa não vai fazer falta! Agora se abandonar, se ele sair, eu não quero nem falar para você! Ali vai se encher de gente! Com ele lá já vai gente cortar. O Jair, irmão do rapaz daquela casa que a gente foi ali denunciou a gente aqui. Ele foi lá no parque, ele falou para o Jorge: vai lá Jorge no Cardoso porque aquele velhinho, o Armando, está acabando com todo o palmito, está tudo pequenininho ele está acabando com o facão! O Adelmo falou pra Jorge: o meu pai não mexe com palmito! Quando ele era novo não digo, mas agora não mexe! Faz muitos anos que a gente não mexe com palmito! Mas ele falou: você tem que ver! Eu acho que é alguém que está lá e ele está pensando que é a gente! A gente já não vai pegar nem para comer, quanto mais para vender né. Faz muito tempo, muito tempo que a gente não mexe! Quando ele era novo a gente tirava daqui. 
A - Sabe o que é? O negócio dele é que parece que eles andaram fazendo desmatamento, os guarda-parque entraram lá e pegaram a motosserra lá em baixo, num barraco lá.

D - Como fala o nome do lugar?

$\boldsymbol{A}$ - Canudal, fizeram desmatamento lá, cortaram com motosserra cortaram muita madeira ali, eu fiquei sabendo disso. Não! Acho que eles nem sabem ainda, nem os guarda-parque não sabem.

$\boldsymbol{D}$ - Então como eles levaram as motosserras? O Adelmo viu eles chegando.

$\boldsymbol{A}$ - Eles viram o barraco e não o desmatamento, o desmatamento é mais na frente, a motosserra estava escondida no barraco. Levaram, diz que a motosserra, e levaram bastante coisa do cara lá, num valor de cinco mil.

$\boldsymbol{D}$ - Dizem que era gasolina, o Adelmo viu o barco chegar, mas ele não gosta de falar, ele não gosta de se intrometer. Mas ele perguntou para mim se alguém tinha motosserra daquele lado de lá. Quando eles fiscalizam e pegam, eles sabem que vão encontrar desmatamento lá. Aí já vão julgar: Vai jogar para cima do Armando! Ele já jogou mesmo! Um dia eles vão ver aquilo e vão culpar quem? Vão dizer que foi ele porque já tem a denúncia lá! Mas aonde a gente vai pôr madeira?

A - Eu sei, mas tem a coisa é essa aí!

D- Igual aqui, o seu José Godoy sempre morou lá para baixo. Faz quarenta e dois anos que eu mudei do Taquari para cá e que eu moro aqui, eu nunca vi o seu Zé Godoy entrar aqui dentro da área do quintal dele, dentro da área do campinho para cá para cortar uma vara para fazer um cabo de faca, um cabo de foice. Ele sempre respeitou os outros. Nunca, ele, a mulher dele, eu nunca vi ele pegar, nunca vi fazer uma roça aqui perto da minha casa, nunca vi! Esse Gilmar veio e depois que ele vendeu a terra dele, ele ficou aqui uns quatro anos. Ele roçava um pedacinho de horta nossa, ele vinha pedir ordem para nós. Depois que aconteceu tudo isso de briga no fórum ele vinha pedir para plantar um pouco de arroz, nunca teve essa brigaiada. O Ademício é genro, casado com a filha do Joao Alves. Lá em Itapanhapima mora compadre Dito, mora o Valdecir, o Nildo.

D - Cinco casas.

A - O Nildo não vai na reunião. Não vai nem o Gentil meu irmão, ele era conselheiro mas agora ele não vai. Ele trabalhava para um cara e onde ele mora virou parque, mas tinha dono lá antes.

D - O Seu Hélio.

$\boldsymbol{A}-$ É, Hélio Medeiros.

D - Ele veio em casa esses dias.

$\boldsymbol{A}$ - O Hélio fica pondo na cabeça dele que ele não pode ficar e a turma do parque também fica pondo na cabeça dele que ele pode ficar. O Hélio disse que não, que quem colocou ele lá foi ele e que ele tem que sair quando ele disser para ele sair. Ele ficou assim, complicado sabe? Porque ficou parque, mas o Hélio falava que era dele. E a turma do parque falou que pode.

$D$ - Ele está contra o Hélio que era o dono antes e está a favor do parque, está a favor do seu Osmar, ele falou que vai deixar o seu Hélio de banda e vai atrás do seu Osmar. Porque o seu Osmar falou que ele pode ficar morando como ele está e a casa que o Hélio fez lá vai ficar para ele. É uma casa bonita de material. O Hélio vai sair sem nada então o Hélio quer receber o benefício que ele tem lá. Ele tem uma fazenda de palmito, ele gastou noventa mil reais lá. Mas eu não sei de quem ele comprou a terra.

$\boldsymbol{A}$ - Não é comprado, é tudo grilado!

$\boldsymbol{D}$ - Ele chegou e acho que ele comprou do...como é mesmo o nome dele? Acho que aqui primeiro foi o tal de Nakashima... aquele acabou em nada né? 
A - Acho que não foi aqui. Do seu Alfredo Sens a divisa do terreno dele ficava por trás do Itapanhapima na divisa do terreno, no Taquari. Itapanhapima é o Hélio que $o$ Gentil é o caseiro.

$\boldsymbol{D}$ - Ele não pode mais entrar aqui.

$\boldsymbol{A}$ - Está no fórum essa guerra, estão brigando, está na mão de advogado.

D - Ele falou que quer só que o Estado pague os palmitos que ele plantou, aí ele não vem mais. Mas ele não tem ordem de vir. Eu acho que não vão pagar mais nada. Eu falei para ele, nem para nós que somos nativos daqui.

$\boldsymbol{A}$ - Na primeira reunião que teve para a criação da reserva que eu falei para o Mario, gestor do parque: o Hélio lá do Itapanhapima disse que lá é dele. O Mario esse do parque, falou assim: se esse Hélio comprou ele comprou porque quis, porque ele era diretor de meio ambiente e sabia muito bem o que ia acontecer. Se ele jogou dinheiro fora era porque tinha para jogar. É, ele estava por dentro da lei.

$\boldsymbol{D}$ - Se ele é diretor de parque e sabia da lei porque ele fez isso?

$\boldsymbol{A}$ - Diz que ele era diretor de meio ambiente. Diz que é! Parece que ele mora em São Paulo mas está sempre ai em Cananeia.

D - Quando você estava lá ele foi lá em casa.

$\boldsymbol{A}$ - Eu conversei com ele esses dias.

D - Ele perguntou do Armando, eu falei: ele está lá trabalhando, plantando, e ele falou: eles pagam vocês? Eu falei: até agora eles estão pagando, a gente trabalha e eles pagam. É o projeto das mudinhas. Eu não tenho nada contra o seu Osmar do parque não. Eu achei muito bom virar reserva. Quando veio o primeiro que era o Wilde, eu falei para ele que estava pedindo para Deus para virar uma reserva, nem que eu perca. Eu não tenho terra para vender, não quero para negócio, quero para ver os meus filhos lá em cima e o dia que nós morrer fica para outro, fica para o Estado. É eu prefiro perder tudo para o Estado, menos que fique para esses grileiros que quase nos matou aqui! Eu falei isso mesmo para ele! Que eu perca tudo para o Estado, mas que não fique com essas pessoas que quase acabaram com a minha vida. Quase me mataram de nervoso, até peguei arritmia, coração tudo, quase morri. Então que fique para o Estado, é melhor ainda! Na primeira reunião que teve sobre esse terreno foi lá na Ilha da Casca. Mas eu falei muito, discuti tanto, envergonhei tanta gente! Todo mundo contra mim, eu levantei na reunião e falei! Estava esse Durvalino, o seu Zé Godoy ali. Era esse Marcos Campolim ${ }^{218}$ que estava na reunião, e ele perguntou se alguém tinha alguma para falar, e eu falei: eu tenho! Eu falei: eles querem terra para vender, eles não querem terra para trabalhar. Eles querem para fazer uma casinha de madeira, passa dois, três meses eles plantam uns pés de bananas e passam para outros. Eu não, eu quero o meu pedaço de terra para eu viver com os meus filhos, pelo menos ao redor da minha casa. O que vocês quiserem que vire parque, mas quero o meu pedacinho de terra pelo menos ao redor da minha casa, para eu acabar de criar o meu filho que era o Nivaldo que ainda era novo. Depois que ele já estiver maior de idade, que já sabe o quer fazer, eu saio, vou para Cananéia, vou para o meu canto. Mas enquanto ele for menor eu quero manter ele aqui, não levar para esse mundo. Então o Durvalino falou assim: eu quero vender, eu quero montar uma loja de roupa, uma venda para os meus filhos, eu quero cento e cinquenta mil reais. E eu falei: você vende mesmo porque você é vagabundo, só vive de vender terra! Eu falei mesmo! O Zico, florestal, guarda parque me cutucou por trás e também falou: Você é vagabundo mesmo, vive de vender terra. Já levantou um monte de gente contra mim, e eu falei:

\footnotetext{
${ }^{218}$ Funcionário da Fundação Florestal.
} 
Eu estou falando a verdade, ele quase nos matou lá, vendeu na maior cara de pau. Saiu seis meses, deixou passar, achou que nós íamos esquecer de tudo o que a gente passou. Ele voltou a morar lá de novo, pediu um lugarzinho para roçar uma roça. Agora vai fazer a mesma coisa, vai vender para pôr loja, por não sei o quê. Terra não se vende! Deus não vendeu terra para ninguém, Deus deixou a terra para gente viver dela, tirar nossa comida! Então o seu Zé Godoy falou assim: você está falando isso para mim dona Dirce? Eu falei: seu Zé, se doeu no senhor, o senhor também fez errado!

Eu não, eu estou falando a realidade. Eu não fiz nada errado. Eu morava lá no Taquari, a minha terra eu não vendi, eu não assinei. O meu pai vendeu para um cara chamado Francisco, a minha mãe assinou. O oficial de justiça veio aqui na minha casa me procurar com um papel: a senhora vai assinar aqui porque o seu pai vendeu para mim um sítio no Taquari. E a senhora é maior de idade já, casada, tem que assinar! Eu falei: eu não, o senhor pode pegar esse papel e levar em branco, e se eu um dia precisar da minha terra, onde eu nasci, eu vou vender a minha terra, eu vou vender a minha vida! É onde eu nasci e não vou assinar. O cara foi embora e até hoje nunca mais apareceu, e o cara perdeu tudo! Comprou do meu pai e perdeu tudo! Eu não assinei! Meu pai é vivo! Ele mora lá, o meu pai, o meu irmão. Perdeu tudo porque não teve como fechar a venda do pedaço que ele vendeu, ele perdeu tudo! Para mim não me deram dinheiro mesmo, para que eu quero trinta mil reais? Eu trabalho e ganho. É, essa história de venda. Um vendia, o outro não vendia. Foi o dinheiro que começou essa brigaiada.

Os irmãos de Armando ninguém vendeu. Eles falam que têm saudade daqui, eles são tudo de idade. Às vezes ele vêm aqui pescar um peixe para comer e no final do dia vão embora! Vem só para matar a saudade. $O$ meu cunhado morava de frente a minha casa aqui. Aquele que mora de frente a nossa casa na cidade onde você foi é meu cunhado também! Aquele que tem a casa murada é Nildo, meu primo. É, por parte da minha mãe ele é теи primo.

$\boldsymbol{A}$ - Ele vai na cidade mas fica mais aqui no sítio

$\boldsymbol{D}$ - Depois que ele aposentou ele fica mais para cá.

A - Ele trabalhava no parque.

$\boldsymbol{D}$ - Ele trabalhou desde novo! Olhe que Nildo trabalhou desde novo, ele nunca saiu do serviço. Para chegar no sítio dele aqui é a mesma coisa que vai na casa do Dito ali, é pertinho uma da outra.

$\boldsymbol{A}$ - Tudo de barco. Tinha trilha por terra mas fecharam os caminhos.

D - Só se pegar o facão um dia e ir abrindo.

\section{"Mas a rapaziada de hoje não quer mais saber dessa vida!"}

Dirce

D - Tinha, sempre um estava na casa do outro, ia jogar bola, ia na missa... Tinha uns caminhos bem grandão, igual aqui mesmo. É que tapou, o matinho cresceu.

$\boldsymbol{A}$ - De primeiro a turma se juntava, de lá vinha, descia e roçava até uma conta. Daqui para lá, nós limpávamos também e encontrava com a parte que eles limparam, era o caminho da escola. Depois que fechou a escola....

$\boldsymbol{D}$ - Acabou a criançada que brincava, que estudava, a criançada era cultura. Eu não sei o que aconteceu que foi tudo embora... sei lá acabou... Aqui eram os meus meninos e os meninos de Lísia, ali se reuniam, vinham brincar de bolo aqui de domingo, era aquela alegria. Depois cresceram, casaram, foram tudo embora e ficou só o pai e a mãe, aí eles desanimaram. 
É o Benedito, Valdeci, Aguinaldo, é Iro, Maurilio e Dito, tudo na cidade, só vem para pescar, nem planta mais porque o velho também está com setenta e poucos anos, ele planta só banana.

$\boldsymbol{A}$ - A mulher dele também tem problema de saúde, então fica complicado.

$\boldsymbol{D}$ - Foi depois que Lísia operou a cabeça também, aí fracassou tudo.

$\boldsymbol{A}$ - Deu um câncer na cabeça dela.

D - Foi, ela tirou tudo essa parte aqui, operou, fizeram cirurgia, disse que era um câncer de um tombo que ela levou. Tiraram o caroço que estava no cérebro, arrumaram esse osso tudo certinho, ela veio pra casa e os pontos não sararam, inflamou tudo. Voltaram pra São Paulo e o osso aqui daqui da frente moeu, tiveram que tirar. Ficou só essa pele, rasparam a cabeça dela, ela ficou usando chapéu quase dois anos, até nascer cabelo. Agora ela tem cabelo de novo. Porque o câncer acaba com o cabelo... Agora ela está boazinha. Mas desde essa vez que eles levaram ela para lá, ela não pode trabalhar. Faz um cafezinho, mas ela não pode mais plantar. Meu Deus o que essa mulher plantava! Eu ia em cada mutirão de plantação de rama dela!

$\boldsymbol{A}$ - Mas a rapazeada de hoje não quer mais saber dessa vida!

D - Sabe o que Fabio meu filho fala para mim? Eu falo para ele: filho vamos roçar essa roça, a gente planta feijão, aipim, mandioca para nós fazermos farinha! E ele fala: mamãe tá ficando velha está ficando louca! Mas ele fala! Mamãe porque eu vou derrubar madeira e cavar chão com tanta farinha na venda para comprar? (Risos)! Falou aqui em casa. Isso daí era tempo do louco mamãe! E eu falo: mas o seu pai criou todos vocês assim! Pois é mamãe! Pois é, mas de tanto derrubar madeira nesse mato quase se matou!

A - Mas eu falo para eles que eles não entendem uma coisa, o que eles compram eles nem sabem o que é! É aquilo que você faz, você está comendo uma coisa que você fez, você sabe que é limpa, pura! Você sabe quantas vezes pisam por cima? Mas dizem que não, que está ensacadinho, bonitinho.

D - A comida não tinha química nenhuma, era verdura, era aipim, arroz da lavoura, feijão. Hoje o que a gente come é metade química. É isso que dá câncer, que provoca uma úlcera cancerosa no estômago, isso é veneno. Tudo com veneno para matar os bichos.

Aqui nunca foi usado nada. Eu aprendi com o Marco Campolim ${ }^{219}$ e com um amigo dele, quando eu morava lá em cima e eles ficaram lá uma semana, eles me ensinaram a plantar horta, eles me ensinaram a cavar. Eu já sabia, mas o jeito que eles aravam a terra era diferente. Eu plantei bastante planta, e ele falou para mim: essa planta que a senhora planta aqui não tem tóxico nenhum e o de lá não, ele vai crescendo com adubo que é veneno, e é tudo contaminado.

Então me ensinaram a fazer um adubo. Ensinaram eu, o Armando, o meu cunhado Gentil. Com as folhas do mato, cortam mas não derrubam as árvores, mas você tira os galhos e amontoa as folhas de vários tipos de árvores. Você faz um monte bem grande e deixa bem amontoado, depois vai virando até virar adubo, menina aquilo você arrumava na terra!

A - E eu falava, sabe que está ficando bom? Ele falava: você pega uma foice, enfia dentro desse monte de folha. A gente enfia o facão e tirava ele de lá. Não dava para pegar nele de tão quente que estava! Estava que nem uma brasa, queimava que ficava que nem café queimado. Ficava três dias ali, bem amontoadinho.

$\boldsymbol{D}$ - Mas era montão mesmo, bem grandão.

\footnotetext{
${ }^{219}$ Funcionário da Fundação Florestal que foi gestor do Parque Lagamar.
} 
$\boldsymbol{A}$ - De cada três dias a gente virava de dentro para fora sabe? Ele ficava preto, passava três dias você virava, mais três dias e virava de novo, virava três vezes e aí estava pronto.

D - Virava adubo de madeira.

$\boldsymbol{A}$ - Sabe por que ele fez isso? Porque eu disse para ele: o meu pai nasceu e morreu aqui e ele dizia que essa terra não dava sem queimar! Ele disse: eu mostro para você se dá ou não dá! E eu disse para ele: eu só posso dizer depois que eu ver, porque meu pai plantou e não deu. Então ele inventou isso. Nós desmatamos uma área e roçamos, e ele dizia para irmos pegando os galhos e folhas. Qualquer tipo de árvore, só as folhas, sem a madeira, você pega o facão e vai cortando, juntando, depois que tem um monte você pega o facão pica mais um pouco, corta bem cortadinho.

$\boldsymbol{D}$ - E até o mato do chão, a graminha.

$\boldsymbol{A}$ - Ele disse que pode fazer, guardar num saco e pode ir usando e ele falou que em qualquer lugar que você colocar dá!

$\boldsymbol{D}$ - Lá onde a gente morava eu plantei repolho, alface, almeirão, eu plantei beterraba, tinha de tudo! A turma daqui ia lá em casa buscar verdura.

$\boldsymbol{A}$ - Repolho que aqui nunca deu, dava cada cabeça! Era bonito de ver!

D - Eu cortava aquele mundaréu e dava para a turma comer, os vizinhos daqui!

A - Eu acreditei porque dava!

D - Eu vou fazer para pôr na minha hortinha ali. Eu estou carpindo ali para fazer! Vou em Cananeia comprar as sementes, de alface... eu sempre mexo com hortinha, eu tinha parado. Até essas semanas tinha mas deu uma seca forte que acabou com a minha hortinha.

$\boldsymbol{A}$ - Ele chamava de adubo verde, ele misturava com a terra, eu achei muito bom. Ele falava que dava de tudo!

$\boldsymbol{D}$ - Eu acho que dá sim! Milho verde ...

A - Ah é gostoso demais! Ah milho é bom demais!

D - Lá em cima nós tínhamos de tudo, lavoura, farinha! A minha filha Maria Rosa que casou com o João, pergunta para o João que ele vai te falar, quando ele tinha dezessete anos ele começou a namorar com ela. Ele ia lá da casa dele lá em cima até em casa, e ela ficava no pilão. Ela pegava um pilão, um banco e ficava o dia inteiro pilando o arroz, ela pilava dois sacos de arroz pra sábado e domingo ela poder ir brincar com as amigas dela. Elas vinham para cá brincar, às vezes posava aqui e no outro dia que elas iam para casa. Elas ficavam tudo aqui brincando... as meninas... mas ela gostava de pilar arroz! Pilava o arroz todo para eu deixar, senão não deixo ir... Fazia tanta farinha! Eu tenho vontade de plantar aqui perto, mas eles não querem mais roçar!

$\boldsymbol{A}$ - Eles não querem roçar, só comer! E nem se compara o que é coisa pura.

\section{“O Armando não sei como não está na cadeia preso! Cinco anos sendo processado!"}

Dirce

D - Eu ainda planto por aqui! Terminando a minha casa lá em Cananeia não sei se vou para lá. Se o Elizeu não for morar lá... mas eu acho que vai porque ele paga aluguel. Ele mora para lá da rotatória, na saída da cidade. Uma casinha alugada. Você já ouviu falar do restaurante do Mike ali? Ele mora naquela rua ali.

$\boldsymbol{A}$ - Perto do mercado Takagi é ali, indo pra rotatória, aí tem uma rua que entra para o Acaraú, é ali que ele mora. 
D - Ele fez contrato quatro meses, agora ia vencer, ele paga baratinho, duzentos e cinquenta. Foi o que matou ele nesse negócio da multa, porque todo mês caía aquele dinheiro. Se não está na rua! A gente falou para ele, fique aqui na nossa casinha, não passe apurado, a gente põe o colchão em qualquer lugar. Mas a mulher dele não queria, ela tinha as coisas para pôr na casa, então a gente não pode contrariar os outros. Eu ainda fui com eles e ajudei tudo, comprei quiboa, desinfetante para ela lavar porque a casa estava abandonada, só que agora tem essa multa. $O$ Adelmo foi multado com esse Fofão, dez quilos, ele teve que dar quatro cestas básicas. O Eliseu por causa de caranguejo. O Armando não sei como não está na cadeia preso! Cinco anos sendo processado!

A - Estava caçando! Eliseu, aquele florestal ruim que falei. Eu gostava muito de caçar.

D - Mas é turrento! E ele foi pra lá e eu falei não vá caçar e não vá matar bicho do mato nenhum! E ele falou: eu vou e vou matar uma caça. E ele foi e posou no mato.

$\boldsymbol{A}$ - Ia que nem índio mesmo! Ou dormia num trepeiro ou no meio do mato andando. Gostava demais.

D - E eu preocupada aqui porque ele falou que vinha no dia e não veio. O Fabio chegou e eu falei para ele que o pai tinha ido caçar e não tinha voltado. Tinha um rapaz que tinha ido com ele que chama Juruna, ele era menino ainda, era menor. Estava também o Claudio que tinha vindo de lá, o Valdeci que tinha quinze anos, tinha esse Paulinho de dezesseis anos, e estava o Antônio foram tudo caçar e dormiram num tronco de madeira no mato.

Eu falei para o Fabio: Eu fui dormir e tive um sonho, e o seu pai foi pego! E ele: mãe, onde no meio desse mato mamãe? E eu falei: Vieram lá do Ariri e levaram o seu pai faz tempo, eu sonhei, eu não pude dormir um sono, eu via eles na escuridão mas não enxergava ele. Contei para minha nora, ela falou: Ai, ai, ai... Gente de idade quando sonha é verdade! E eles não apareceram, passou três dias! Já pensou... Eu aqui quase louca, quase desmaiando, pensando: levaram ou mataram. Lá tinha o jagunço lá no fundo e o Alfredo tinha denunciado ele para a Polícia Florestal. Os policiais florestais entraram pelo mato e levaram todos eles presos. Três espingardas! Ele com duas e o Antônio com uma! Tudo junto! Valdeci foi preso com quinze anos, o Paulinho vizinho foi preso com dezesseis anos, foi tudo com ele que era maior. Antônio também junto!

Eu pensava que uma onça comeu, algum bicho comeu! E eu não entro aí no mato para dentro porque eu me perco, se for pelo caminho eu vou. Quando eu olhei eles estavam vindo de Cananéia, a minha cunhada tinha pagado a fiança. Os meninos ficaram detidos porque estava com ele mas foram liberados porque eram criança, não foram processados. Não chegaram a dormir porque a minha cunhada viu!

$\boldsymbol{D}$ - Ah mas também matar raposa lá!

$\boldsymbol{A}$ - Eles pegaram um pedaço de paca ainda né? Os meninos que pegaram para comer no barraco, quando a gente chegou eles estavam chegando lá. Fizemos uma cozinha para cobrir, com a palha e quando eles chegaram o menino saiu correndo $e$ deixou a espingarda e o pedaço da paca. Ele era criança e se assustou quando viu o policial, e ele conhecia todos eles, inclusive o Elizeu. E ele pegou na boa! O sargento falou cada coisa para mim! Ele falou você, não falou senhor não, você não está na cadeia mas eu vou no fórum ver como está o seu caso porque você tem que estar na cadeia!

$\boldsymbol{D}$ - Falaram isso quando eles chamaram, ele tinha que ir lá todo mês, estava sendo processado.

$\boldsymbol{A}$ - É que depois eu tinha que recorrer e passar pelo destacamento. Ia no Fórum mas tinha que passar pelo destacamento. Destacamento florestal. 
$\boldsymbol{A}$ - Não dormimos, ficamos só esperando aquela bobeirada deles, eles fizeram a gente esperar até meia noite. Pagamos a fiança e saímos. Parece que foi cem reais. De todos deu cem reais, o Dito deu um cheque!

$D$ - Esse meu filho Antônio até hoje não pode tirar o CPF, ele chora, não tem título! Porque com multa ambiental não pode!

$\boldsymbol{A}$ - Ela demora sair. Veio no nome dele, ele assumiu uma arma e eu assumi duas!

$\boldsymbol{D}$ - Faz tempo! Ele pagou cinco anos de processo e até agora não consegue CPF. Essa semana ele tirou um documento criminal lá do fórum para poder regularizar, porque sem CPF ele não tira o título, porque quem está processado não pode votar.

$\boldsymbol{A}$ - Ele tem que pagar no escritório criminal do fórum uma certidão, ele paga quarenta reais e eles liberam.

$\boldsymbol{D}$ - Ele já não votou eleição passada. A certidão é de que ele pagou tudo.

D - Os policiais florestais sempre andam por aí. Eles têm barco mas eles chegam e guardam. Ali no João Cardoso porque ali tem sempre lugar de mato para andar. O seu João Cardoso... eu sempre ia na casa dele ... ele mora no Carijo 220 agora, a filha dele teve câncer e teve que tirar os dois seios. Quando eu fui lá ela estava se recuperando, eu não sei se ela se recuperou.

A - Aquele ali nasceu ali mesmo no Cardoso.

D - Estava muito velhinho... Foi bom levar ele para Cananeia.

A - A mulher dele tinha um problema na coluna que ficou curvada e anda quase com a cabeça no chão.

$\boldsymbol{D}$ - Agora ela está bem forte, as irmãs dela tratam dela.

$\boldsymbol{A}$ - Eles não tinham mais condição de ficar ali.

$\boldsymbol{D}$ - Um casalzinho de velho, a menina que era oforte deles caiu doente.

A - Eles só tinham essa filha e ela nunca casou. Faz muitos anos que eu fui na casa dele, muitos anos atrás, ele tinha mais ou menos umas cinquenta cotias e chamava elas todas pelo nome! Elas estavam no mato andando, ele chamava pelo nome elas vinham, quarenta, cinquenta! E tudo o que é nome.

D - Tudo que ele cuidava só para boniteza! Tudo para ele era festa! Era igual cachorrinho!

A - Quando chegava gente ele mostrava as cotias. Então o povo começou a ver, porque ele chamava para ver ele chamando elas pelo nome.

D - Será que mataram?

A - Ah mataram! Os caçadores mataram tudo! Os caras que iam na casa dele e viam as cotias, ele sabe quem matou. Ele se queixou muito dos índios pra mim, ele disse que os índios judiaram muito dele. Mexiam, roubavam dinheiro dele, roubavam às coisas dele. Ele falou que dinheiro era bobagem deixar em cima da mesa. Porque era só ele e a esposa, ele deixava o pagamento dele, a aposentadoria, em cima da mesa e saía. Quando ele voltava eles já tinham levado! Eles contaram para gente mas pedia que eu não contasse para ninguém.

$\boldsymbol{D}$ - Ele me contou que eles cortavam o bananal dele.

A - Ele me contou muita coisa daquela raça de índios ali! Ele ia no bananal cortava banana e às vezes não podia trazer tudo de uma vez... os índios levavam tudo!

D-Mas índio é assim mesmo.

$\boldsymbol{A}$ - Não, mas eles têm a FUNAI que ajudam eles! Não precisa né?

D - Mas será que tem índio que não mexe? Deve ter, né? Já teve muito índio ali perto do seu João.

${ }^{220}$ Bairro da cidade de Cananeia 
A - Eles desmatam muito ali! A polícia ambiental apareceu lá porque tiraram uma foto de avião e apareceu uma área muito grande de desmatamento porque eles fizeram uma roça muito grande. E essa área era dos índios.

$\boldsymbol{D}$ - Mas roça de mandioca ou de cana?

A - Eu não sei, parece que eles plantam banana. Ali no Canudal, o Danilo afilhado ia sempre no sítio do pai dele, eles falavam que tinha um bananal muito grande, muita raça de banana, uma área muito grande.

$\boldsymbol{D}$ - Eles sobem numa árvore, amarram um cabo de aço, eles fazem um laço, enchem de comida, não sei o que eles colocam lá. Então o bicho vai, eles vão lá arcam e armam. Se cair uma pessoa, morre! E na hora que a caça entra no laço sobe para cima e o bicho sobe enforcado, mas é um perigo! O seu João falou que era no caminho de ir para a roça que eles faziam muito.

$\boldsymbol{A}$ - Eu não sei como pode índio morar dentro de um parque.

D - Eles levam para tomar conta, para os índios olhar, porque eles não deixam muita gente entrar.

$\boldsymbol{A}$ - Parece que tomaram as terras deles né?

D - Ali perto do inferninho ${ }^{221}$ que eu falo pra você, ali no Acaraúi222, tem uma aldeia dos índios e tem bastante casa deles. Casinhas boas de madeira.

$\boldsymbol{A}$ - Tem uma vila deles. São eles que ficam na praça, eles vão no Cardoso, voltam para lá, eles têm um barco deles mesmo.

D - Eles plantam tudo lá onde eles moram no Acaraú, o meu neto foi lá e eles deram milho verde, abóbora para o Felipe. A Gilda falou para ele largar de ir lá porque índio é índio, é capaz de eles fazerem alguma coisa pra você e ele disse: que nada eles são bonzinhos mãe! Deram abóbora para o Felipe, milho verde, eles plantam, tem cana, tem tudo, eu passei uma vez lá.

$\boldsymbol{A}$ - Não, não é muito perto não. Tem que ir de carro lá. Nós fomos para Cananéia e fomos por aqueles portos ali. Eles têm até luz.

D - Não tem água menina, não dá para tomar banho.... Nivaldo está arrumando!

${ }^{221}$ Segundo Dona Dirce é o principal ponto de venda de drogas em Cananeia e reúne muitos jovens da cidade com música alta e festas pela madrugada.

${ }^{222}$ Bairro da cidade de Cananeia muito próximo à área central do município. 


\subsection{Reserva de Desenvolvimento Sustentável Itapanhapima}
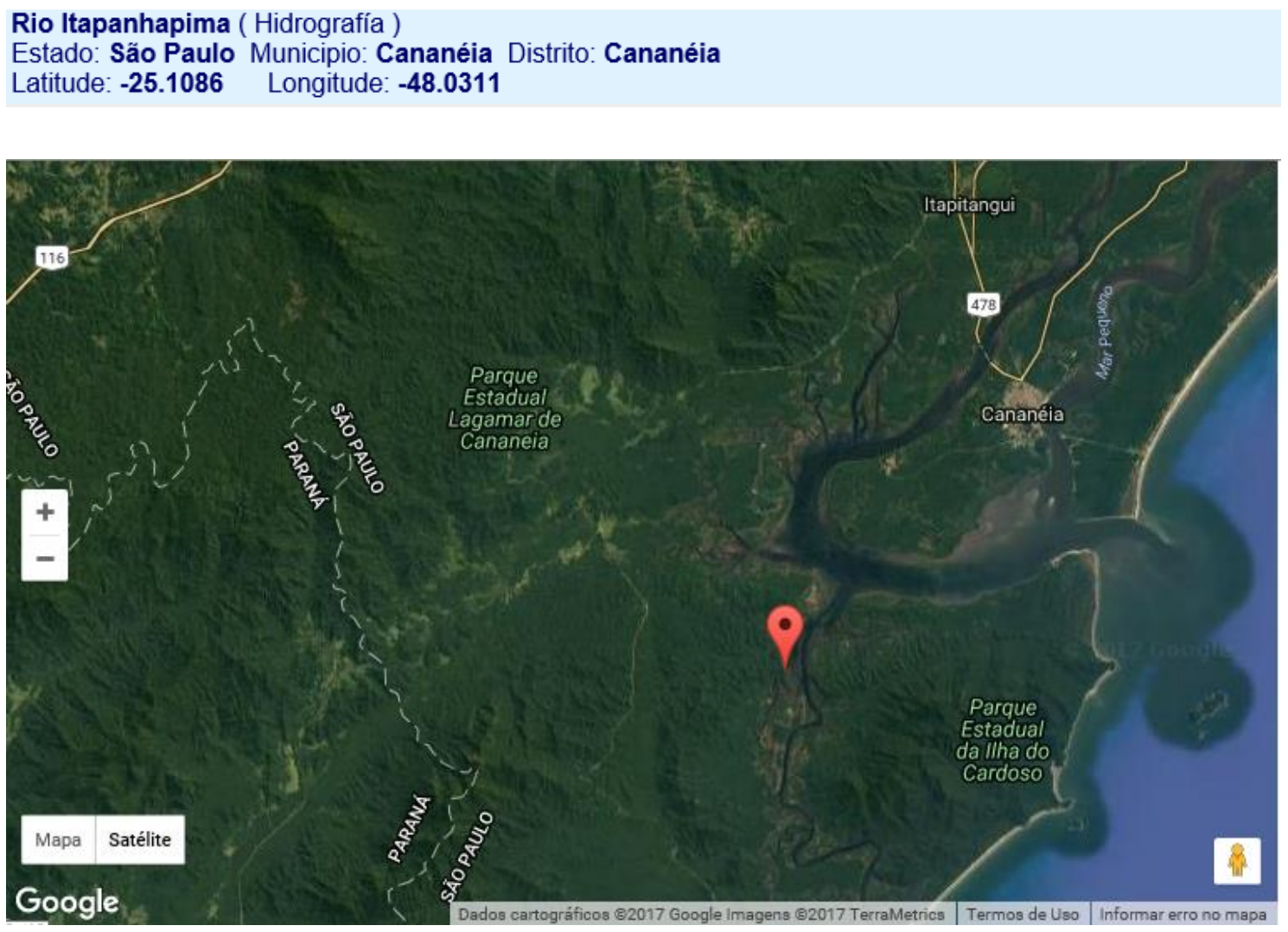

Fonte: http://mapasamerica.dices.net/brasil/portugues/mapa.php?nombre=Rio-Itapanhapima\&id=34658

A RDS Itapanhapima é composta pelos bairros Itapanhapima e Bom Bicho e ambos localizavam-se no entorno do Parque do Jacupiranga e dentro da Unidade de Conservação federal denominada Área de Proteção Ambiental Cananeia-Iguape-Peruíbe (APACIP,1985). Apesar de também sofrerem ações de repressão por parte do Estado e da polícia ambiental, não foram incialmente incluídos no projeto do MOJAC. Trata-se de uma área com alto grau de conservação ambiental e por isso seu entorno foi considerado pelos técnicos do Instituto Florestal como ideal para a compensação exigida pela desafetação do Parque Estadual do Jacupiranga. A importância da área para os ideais de conservação já havia sido diagnosticada nos anos de 1990, o que pode ser constatado pelo projeto da Estação Ecológica Ariri - Itapanhapima, unidade de proteção integral que não chegou a ser implementada ${ }^{223}$ e tinha como um dos principais objetivos proteger diversas espécies ameaçadas, dentre elas, o mico leão caiçara e o papagaio de cara roxa.

223 BIM, op.cit.92 


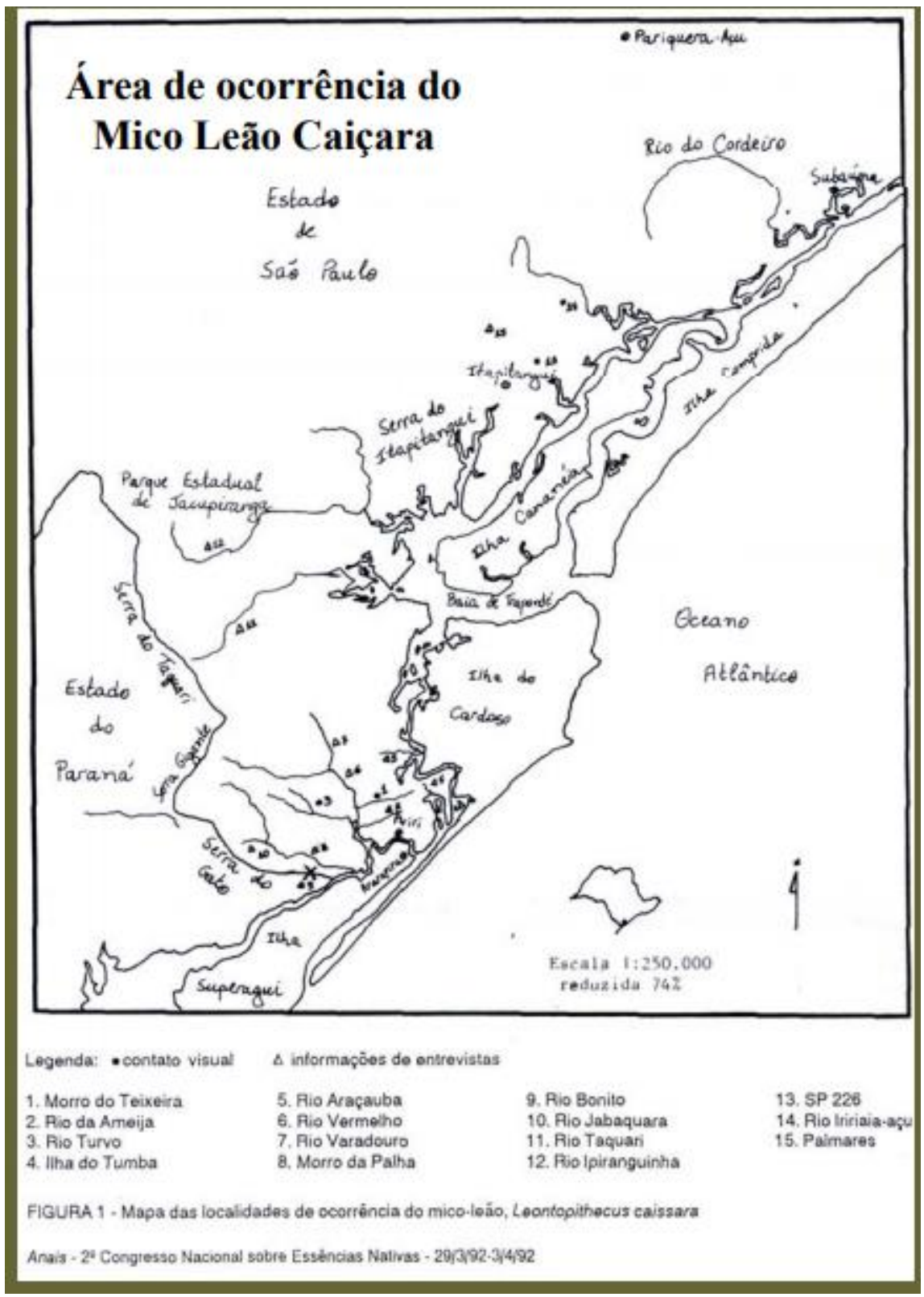

Fonte: Projeto PEJ/ Mosaico do Jacupiranga 224

Apesar de serem unidades de conservação concebidas, do ponto de vista legislativo, com aspectos semelhantes, sobretudo nos quesitos relacionados à proteção da biodiversidade e sociodiversidade, tratam-se de categorias distintas na medida em que a RESEX prevê mais claramente a ideia de área de uso voltada para o extrativismo, enquanto a RDS não utiliza explicitamente tal característica. Dessa forma, as categorias

${ }^{224}$ http://www.rbma.org.br/programas/docs_programas/mosaicos_corredores_ecologicos/02_21_02.pdf Acesso em janeiro de 2013 
implementadas - Reserva Extrativista e de Desenvolvimento Sustentável - aproximam-se por permitir a presença antrópica e diferenciam-se pelo de fato de:

A diferença em relação à definição jurídica da reserva extrativista está no fato de que a reserva de desenvolvimento sustentável refere-se apenas às "populações tradicionais", sem acrescentar o termo "extrativistas" e, portanto, sem uma preocupação tão centrada no extrativismo. ${ }^{225}$

Outra diferença se dá na origem das propostas, já que a noção de reserva extrativista partiu de mobilizações populares, enquanto a de desenvolvimento sustentável foi elaborada por ambientalistas preocupados em readequar a conservação de determinadas áreas às novas demandas socioambientais. Assim como a RESEX, trata-se de uma categoria de conservação ambiental que nasceu na Amazônia, mais especificamente com a implementação de sua primeira unidade: A Reserva de Desenvolvimento Sustentável Mamirauá ${ }^{226}$ surgida em 1992 a partir de uma proposta de recategorização de uma unidade de Proteção Integral - a Estação Ecológica do Mamirauá.

Dessa forma, trata-se de uma categoria implementada à realidade de Cananeia com o mesmo intuito da RESEX Taquari: viabilizar a permanência de populações tradicionais em áreas que foram cercadas pelo Parque Estadual do Lagamar em decorrência da implementação do MOJAC. No entanto, a RDS foi criada sobre as áreas de moradia, sendo seus beneficiários apenas a população do seu interior.

A partir do reconhecimento legal da permanência das populações tradicionais, o conflito se desloca do aspecto jurídico para a forma como se conduzirá a reorganização do território sob as diretrizes da recém-criada legislação. Reconhecidas como as mais avançadas em termos socioambientais, as UC's sustentáveis deram origem a um arcabouço legal para um novo padrão de relação participativa entre o Estado representado pela Fundação Florestal - e usuários e moradores de unidades de conservação e do seu entorno, estes reconhecidos como possíveis aliados no propósito de conservação. Entretanto, entre a legislação concebida e o vivido pela população existem diferenças claras, de forma que para muitos de nossos colaboradores, a proposta socioambiental não foi ainda capaz de se sobrepor à memória de conflitos fundiários,

225 SANTILLI, op.cit.p. 155

226 FERnANDES-PINTO, E. As RESEX e RDS e a Política Nacional de Povos e Comunidades Tradicionais - Interfaces com a Etnobiologia e Etnoecologia - Resumo expandido apresentado no VII Simpósio Nacional de Etnobiologia e Etnoecologia (VII SBEE), Belém/Pará, dezembro de 2008. 
perseguições ambientais e injustiças territoriais sofridas durante o processo de demarcação da unidade de conservação. Sobretudo Armando e seu filho Nivaldo associam a injustiça à falta de fiscalização para com os "grandes" e excesso de fiscalização para com os "pequenos". Ambos ressaltam a presença em Cananeia de muitos agentes da pesca industrial provenientes de outros estados, sobretudo os "cariocas", vindos de Angra dos Reis. Para eles, os moradores da região são impedidos de acessar diversos recursos naturais em decorrência da legislação, enquanto muitos pescadores industriais são beneficiados pela negligência pública, sobretudo da polícia ambiental. Armando relembra das punições referindo-se a dois policiais ambientais nominalmente citados: Magalhães e Eliseu. Para ele, trata-se de figuras autoritárias que não reconheciam os direitos das populações locais conferidos pela APACIP, e preocupavam-se apenas em aplicar os procedimentos técnicos e legais sem qualquer sensibilidade em relação a elas e suas demandas. Ele relembra do episódio em que foi preso por estar caçando na região e foi enquadrado pela lei de proteção à fauna. Ele e os filhos passaram a noite na delegacia, pagaram fiança e respondem aos processos até os dias de hoje. Sua indignação refere-se primeiramente ao fato de que a caça de subsistência sempre foi uma atividade praticada por ele. Outro fator é que ele, assim como outros entrevistados e moradores da área rural e urbana, parece conhecer quem são os caçadores que lucram vendendo a carne de animais silvestres, ou levando pessoas para caçar em áreas de conservação ambiental. Dessa forma, apesar de ser de conhecimento geral a existência de freezers lotados de caça, nada é feito contra essas pessoas. Ele cita em especial o caso de Durvalino, um morador tradicional que se vale de sua condição para caçar e, antigamente, antes da implementação da reserva, também para vender terrenos.

Nesse aspecto é interessante notar que dentre os colaboradores, a única que parece associar a reserva a avanços que beneficiaram a população local é Dirce. Para ela, a saída dos moradores da área precede a criação do "parque" (a atual reserva) e se associa mais aos conflitos de terras entre famílias que passaram a vender suas áreas para fazendeiros e empresas, como o episódio por eles narrados que envolve a empresa Sulcar. Outros fatores apontados por ela foram a atração exercida pela possibilidade de ganhar dinheiro na cidade, e a ausência de estrutura mínima para que as pessoas pudessem ficar, sobretudo no quesito escolar, posto que a escola do bairro foi fechada com a diminuição dos alunos. Quando seus netos e outras crianças da área chegaram à idade escolar, a escola não mais existia, o que obrigava a migração dos pais para a cidade. Além disso, o tom mais enérgico de sua fala refere-se à violência exercida pelos grileiros utilizando várias técnicas de 
intimidação, como arames farpados em volta das casas, festas com geradores de energia regadas à bebida no meio da madrugada que não os deixava dormir, quebra de canoas no porto, etc. Segundo ela, tal fato prejudicou sua saúde, traumatizando a ela e aos filhos. Dessa forma, sua fala é enfática em relação à ideia de que terra não se vende e de que prefere perdê-las para o "parque" do que para os grileiros que tanto maltrataram sua família. Ela ressalta também sua grande gratidão à Maria Aparecida Rangel, a Cida, e ao Padre João 30, que lhes forneceram apoio psicológico, político, jurídico e econômico para enfrentar a ação dos grileiros. Assim, mesmo que ela interprete a chegada do parque como algo negativo - devido à perda de liberdade de mobilidade no território, às perseguições e punições por meio das multas, e à proibição de roças e demais atividades tradicionais ao seu modo de vida -, a marca de violência deixada pelos grileiros é tão presente que ela se coloca como uma das defensoras da reserva. Para Armando, apesar de não compactuar de forma tão explícita com a posição da esposa, a reserva também trouxe alguns benefícios, como a diminuição da ação da polícia ambiental. Segundo Armando:

\footnotetext{
Depois que saiu essa reserva, que o seu Osmar veio para cá, a única coisa que melhorou foi a polícia ambiental, porque eles não deixavam a gente trabalhar. A gente encostava no mangue para tirar a ostra, eles falavam: vem aqui, vou levar o barco! Corre, vem aqui que eu vou levar o barco porque está abandonado. A gente tinha que correr, deixava de tirar a ostra para ver o barco... Mas isso era só encostar no mangue que pronto, eles já estavam lá.
}

No tocante ao processo formal de regularização da área, como as reuniões realizadas para apresentar e discutir o projeto da RDS e, posteriormente, para elaborar o Plano de Uso previsto pela legislação do SNUC, Armando e Nivaldo são críticos em relação à definição da área da reserva. Segundo Armando, o advogado e o grupo de trabalho da Casa da Floresta, empresa contratada para a realização do estudo da área e elaboração do plano de uso, junto ao gestor Osmar, realizaram visitas ao seu sítio. Nesse momento, ele já demonstrava aos técnicos os problemas relacionados à demarcação. No entanto, como esta já havia sido oficializada, pouco pôde ser feito. As críticas em relação à área da Reserva dizem respeito sobretudo ao pequeno espaço destinado às famílias, que foram tolhidas do acesso às áreas próximas ao morro, onde seria possível plantar milho, feijão, mandioca, dentre outras culturas. $\mathrm{O}$ acesso restrito apenas à área de restinga próxima ao mangue apresenta dificuldades de produção que inviabilizam o plantio. Armando destaca que tais atividades de plantio de roças (sem a realização de queimada) foram apresentadas como direitos inalienáveis das populações tradicionais locais, mas 
Nivaldo pondera que o medo da repressão e das multas por parte dos beneficiários desencoraja o plantio. Dessa forma, fica claro o pouco conhecimento que os beneficiários possuem acerca de seus direitos e deveres, mantendo-se a ideia de que "nada pode e tudo é proibido", e há pouca clareza em relação a suas áreas de trabalho. Segundo Armando:

\footnotetext{
Nós não sabemos ainda onde é a nossa área de trabalho porque a gente está com um parque atrás de nós e um parque na nossa frente. O Parque Lagamar está atrás de nós e a Ilha do Cardoso que também é parque, está na nossa frente. Nós vamos para lá e não pode, viemos para cá e não pode também!
}

Dessa forma, as principais reinvindicações identificadas referem-se a maiores esclarecimentos quanto às formas e espaços em que as atividades de trabalho podem ser exercidas, e à ampliação da área da reserva. Para seu Armando e Nivaldo, este é um problema de difícil solução, posto que para esta ampliação ocorrer, outra área deve ser incluída na categoria de proteção integral, o que iria "cobrir um santo para descobrir outro!". No entanto, o aumento da área, na visão dos colaboradores, é essencial para que se cumpram as promessas legislativas apresentadas pela unidade de conservação sustentável, pois permitiria o acesso a recursos naturais fundamentais à manutenção de suas tradições. A questão do uso da madeira é fundamental nesse quesito, pois envolve a construção de canoas, sem as quais é impossível trabalhar nas áreas de mangue. Segundo os moradores, sobretudo nas áreas estreitas do canal e em períodos de baixa da maré, a canoa é a única embarcação plenamente adaptada a tal condição física e geográfica do território, sendo fundamental para o trabalho de extrativismo no mangue, como a coleta de ostras, principal atividade econômica desenvolvida por eles no momento presente. No entanto, as madeiras por eles identificadas como ideiais para a construção da canoa caiçara, como a do guapiruvu, encontram-se nas áreas do Parque Estadual Lagamar. O gestor dessa unidade de conservação no momento da entrevista era Mario Nunes, antigo funcionário da Fundação Florestal. Ele é identificado pelos moradores como intolerante e pouco sensível às suas necessidades e, segundo Noêmia, é uma espécie de traidor, tendo em vista que ele e sua família são do Vale do Ribeira, o que proporcionou a ele amplo conhecimento sobre a realidade e as demandas da população rural. Segundo alguns colaboradores, a postura intransigente e autoritária de Mario Nunes é um dos entraves ao bom relacionamento entre a instituição gestora e os beneficiários. Segundo Armando, ele não comparece às reuniões do Conselho Gestor para prestar esclarecimentos ou negociar alternativas, e quando são realizados pedidos de corte de madeira ou mesmo de retirada 
de madeira morta já derrubada da área do Parque Lagamar, estes são prontamente negados pelo gestor. De acordo com as narrativas de outros colaboradores, a atuação desse gestor demonstra a dificuldade de diálogo entre beneficiários e funcionários da Fundação Florestal.

Ainda no tocante à questão da canoa caiçara é importante frisar que ela foi reconhecida pelo IPHAN (Instituto do Patrimônio Histórico e Artístico Nacional) como patrimônio cultural imaterial. Dessa forma, suas técnicas de produção, sobretudo o trabalho de entalhe de um único tronco, foi reconhecido como parte da riqueza cultural do país. $^{227}$ Dessa forma, inviabilizar o acesso à madeira impede que tal técnica seja preservada, como ocorreu com o Eliseu, filho de seu Armando, que, segundo Dirce, é um exímio canoeiro que não consegue nem realizar e aprimorar seu trabalho, nem ensinar a técnica às novas gerações.

${ }^{227}$ http://canoacaicarabrasil.blogspot.com.br/ Acesso em março/2017. 


\section{$\underline{\text { Seu Gentil e Dona Isabel }}$}

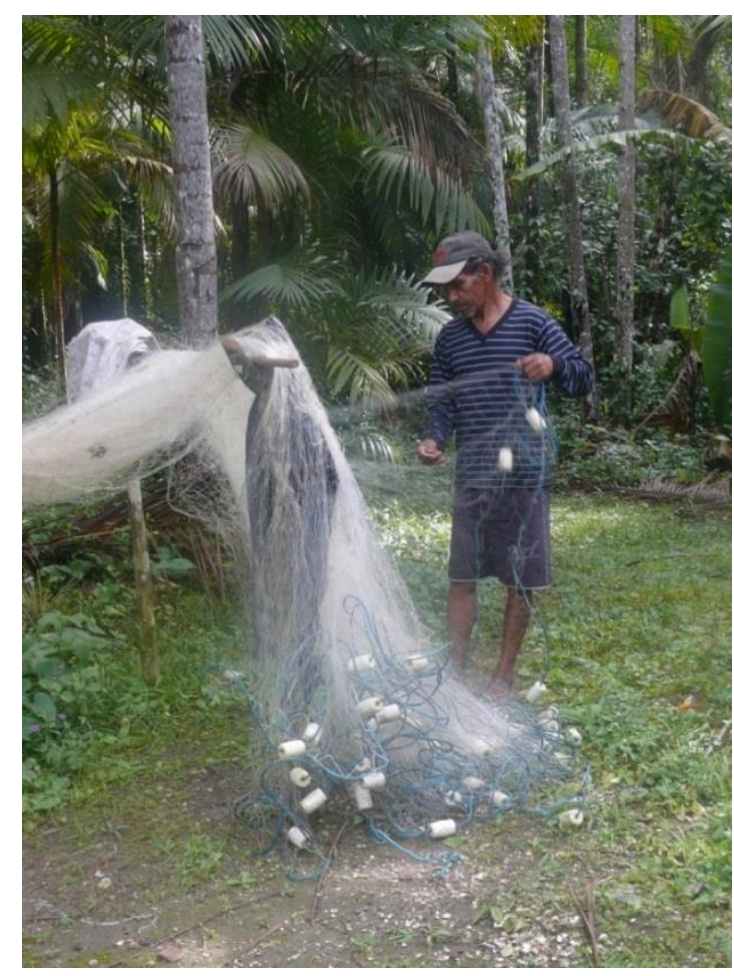

Gentil Davi

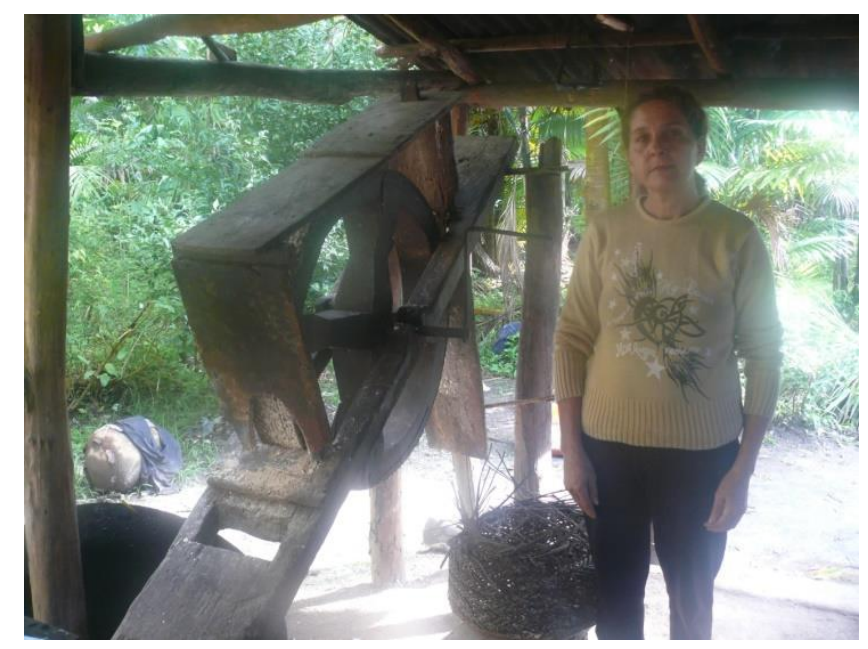

Dona Isabel e a casa de farinha

Seu Gentil e Dona Isabel são parentes muito próximo de Dona Dirce e Seu Armando e também residem na Reserva de Desenvolvimento Sustentável Itapanhapima. Um dos poucos colaboradores com quem não tive contato por meio das reuniões do Conselho Gestor Deliberativo, sendo apresentada a ele por Nivaldo, filho do seu Armando que me levou até sua casa. Talvez por não ter conhecido o projeto de pesquisa apresentado na reunião, mostrou-se inicialmente bem arredio e reticente a falar. O principal motivo da desconfiança era a associação que ele imaginava existir entre a entrevista e a Fundação Florestal. Após a explicação dos objetivos da pesquisa, negociamos as condições de colaboração para o trabalho. Entrevista realizada em julho de 2014. 


\section{"É reserva, é parque e acabou!"}

Gentil

É complicado e não adianta a gente falar um monte de coisa. Porque fala um monte de coisa e eu assino embaixo, depois chega só o papel. É sua assinatura? Você que apoiou isso aqui? E eu fico responsável por aquilo! E daí é alguma coisa que a contra a gente...

Como o que eu falei aquele dia que eles vieram fazer o cadastro: foi feita a Reserva, saiu à reserva, mas tinha um benefício para as famílias. Agora não tem benefício, ninguém pensa em ajudar ninguém, e as famílias ficaram. Ninguém vem fazer uma visita, eles não querem nem saber. É reserva, é parque e acabou! Eu acho que tinha que ter uma ajuda, eu não sei se pode ter para as famílias, vocês tinham que criar um trabalho dentro da área para preservar. Criar um trabalho que não precisasse fazer desmatamento. Colocamos alguma coisa, aí o outro dizia: pode começar a trabalhar. Mas eu não posso começar! Que nem a gente falou das abelhas. Abelha é uma coisa que a gente cria e trabalha com aquilo, não faz desmatamento e não faz nada. Mas então teve um que falou: você quer trabalhar com abelha, pode ir lá! Mas eu não entendo desse assunto, um cara falou que para começar tem que ter seis mil reais só para o começo e depois vai ter que ter mais dinheiro, mas isso não é para nós porque nós nem ganhamos salários! Aí eu falei e o Osmar falou: quer trabalhar com abelhas pode começar! Mas para mim Ele joga para cima de mim e eu não posso fazer! E eles não querem fazer desmatamento. O outro falou para criar galinha. Como criar galinha? Se comprar ração, quanto a gente for matar a galinha está valendo mais de vinte mil no preço que está à ração... Eles ficaram olhando para cima...

Então falei dos morcegos, a gente começou a criar galinha e a noite elas ficam tudo no escuro, então vem os morcegos e toda noite aparecia uma morta porque os morcegos matam! E eles disseram que não sabiam que os morcegos matavam as galinhas, mas a gente sabe por que a gente já passou por isso! Aí fechou a história da galinha também! Criar abelha, galinha e agora o quê?

Se você vai cortar palmito o florestal aparece. Se for pegar um peixe, você cata um peixinho e põe para vender, você precisa ter carteira senão você leva multa. 
Eu fiz uma vez a carteirinha do IBAMA ${ }^{228}$, mas larguei mão porque não pescava para vender, aí tinha que tirar de novo, eu desisti. Mas os filhos era para terem, eu já insisti para fazerem, mas eles não fizeram. Até agora eles não quiseram.

Isabel - Mas aqui era bom ter por causa disso.

Gentil - Pode ser desde que possa vender....

I - Para eles era bom ter porque poderiam pescar tranquilos, não tem florestal que pegue e bata neles e leve o barco.

$\boldsymbol{G}$ - É fácil tirar mas pode demorar uns dias. Mas os meninos não se interessaram.

I - Eles trabalham com pesca

$\boldsymbol{G}$ - É que tudo pertence ao mar é pesca, então você trabalhar com ostra vale para pesca, trabalhar com peixe vale para pesca, tudo que é do mar tem que ter a carteira porque se não os caras pegam e multam.

$\boldsymbol{I}$ - Nós pegamos ostra e a gente vende para aquela firma do Jacques.

$\boldsymbol{G}$ - Aqui é só ele, é o maior que tem. Porque às vezes uns outros querem comprar, mas começam e daqui a pouco se acaba e ele ficou, ele tem uma firma. E ele diz que paga barato porque diz que tem empregado para limpar ostra, paga carro para levar... A gente diz que ele paga barato, mas a gente não sabe a despesa dele, a gente não sabe como funciona né?

Deve ser levado para a cidade grande. Eu não sei para onde ele leva, a quantidade é grande né? Dizem que aqui em Santos e Guarujá uns tempos atrás uma dúzia de ostra é quinze reais, e aqui eles pagavam um e cinquenta. Agora eles pagam dois reais à dúzia.

Mas se alguém tivesse carro a gente podia pegar e levar a ostra. Mas quem? Pegador de ostra lá tem carro?

A gente leva ali de barco outros levam de canoa. Então a gente leva no lugar mais fácil, eu não sei para quem dá dinheiro, mas para eles deve dar, porque eles não compram a dois e vendem a dois, alguma coisa para eles deve dar!

Que nem o cara do peixe, o parati é vendido a dois reais o quilo, e lá na feira de Pariquera ${ }^{229}$ estavam vendendo a cinco reais o quilo. É, e perto, agora imagino que se levar para fora é um preço grande.

\footnotetext{
${ }^{228}$ Instituto Brasileiro do Meio Ambiente e dos Recursos Naturais Renováveis.

${ }^{229}$ Pariquera-Açu, cidade vizinha e que precede Cananeia em relação à proximidade com a BR-116.
} 
No tempo, o primeiro florestal que eu conheci foi o Magalhães. Era quase só ele que fazia essa ronda, foi um dos primeiros policiais florestais que começaram a andar por aqui.

Naquele tempo o Cardoso já era parque, e aí começou, pega daqui, pega dali. Então ele saiu e entrou tal de Elizeu. Nossa se falavam para ele que lá em Itapanhapima ${ }^{230}$ estavam fazendo uma canoa, no dia seguinte ele pegava dois, três e obrigava levar ele no mato onde estavam fazendo à canoinha. Era triste. Foi então que começou, parece que ele abriu o caminho para os outros fazerem o que ele fazia! $O$ Magalhães vai quarenta anos. Eles também foram ao Cantagalo ${ }^{231}$ para multar quem estava fazendo queimada naquela época. A Izabel está com cinquenta e dois anos, eu estou com sessenta e oito. E naquele tempo os meninos eram crianças ainda. Esse era o Magalhães, mas esse Elizeu faz uns trinta anos. Ele trabalha às vezes de vigia para o pessoal, em mercado.

É então faz uns trinta, quarenta anos, porque quando o Magalhães estava aqui, esse Elizeu já estava junto. Depois o Magalhães saiu e ele ficou sozinho. Ele engrossou porque ele ficou sozinho. Nesse tempo a gente morava ali perto do Armando no Retiro ${ }^{232}$. Ali era quase a mesma coisa daqui. Tinham mais famílias no bairro, agora tá só o Armando ali, mas naquele tempo tinha cinco ou seis famílias. Mas só que a saída do pessoal do sítio não foi só porque a polícia florestal não deixou. Se eu estava fazendo uma canoa não era só o florestal que não deixava, era alguém que via e falava que não podia fazer e denunciava. Aí eles vinham em cima.

Eram vizinhos bobos... se você fizesse uma roça, cortasse uma madeira de 8, 10 metros - e precisava tirar porque ninguém vai plantar no mato - o cara ia lá denunciava que estava fazendo uma roça, porque se não podia para ele para mim também não podia e mandava eles virem aqui ver. Eles vinham aqui abrir uma multa em um coitado que não tinha nem dinheiro para comprar arroz!

No tempo do meu pai lá no Retiro, o Magalhães não multou porque ficou com dó! Estava o meu pai e a minha mãe trabalhando. Ele entrou falando com a minha mãe que falou um monte para ele, que disse: então a senhora pode plantar a sua rocinha que eu aqui não venho mais! Ele ficou com dó da velha, ela estava trabalhando naquela rocinha para tirar alguma coisa para comer! Ele ia largar uma multa em cima de quem ali? A

\footnotetext{
230 Área tradicional cujo nome dá origem à RDS Itapanhapima.

231 Bairro que compõe a RESEX Taquari.

${ }^{232}$ Uma das áreas tradicionais que compõem a RDS Itapanhapima.
} 
gente não tinha como pagar a multa. Então ele viu a necessidade e disse que não viria mais! Mas ele não foi por ele, mas os outros o chamavam, e até hoje acontece isso daí! Aqui na bica, eu fiz um barraquinho ${ }^{233}$ na beira do mar para trabalhar com ostra. Então um cara disse que não pode fazer nada lá porque a área era dele. Ele cuidava do terreno lá e ele chamou a polícia florestal. Ainda não era parque, estava começando o parque ainda.

I - Já tinha tempo que o barraco estava lá e depois virou parque Lagamar.

$\boldsymbol{G}$ - Então eles vieram aqui e ia sair uma multa pesada. Mas era época de eleição e eu chorei para um vereador e ele mandou retirar aquela coisa que ele fez para mim porque eu não tinha como pagar a multa. Então tiraram a multa. Esse que me denunciou mora em Cananéia.

I - Ele tem um barraco lá para baixo.

$\boldsymbol{G}$ - Tira caranguejo, ostra, pesca ele pega qualquer coisa. Nunca vi pegarem ele. Aqui, eu na minha parte nunca denunciei ninguém, mas tem gente aqui que não pode ver nada que já denuncia! Que nem esse pessoal que pesca baiacu, esse povo é enjoadinho, mas eu os deixava aí, amanhã eles já iam embora. Ah mas aqui é reserva! E eu digo: o pessoal vem lá do Paraná pescar baiacu para levar para lá e vender. São uns coitados, e passava dois, três dias eles iam embora. Então o pessoal lá do Mandira ${ }^{234}$ e do Itapitangui denunciaram ${ }^{235}$, então eles atendem. Lá no Mandira eles pegam pesado. Mandira pediu, eles atendem porque lá eles têm associação. Mas se eles pedem o cara atende porque lá é obrigado a atender.

I - Aqui acho que não querem ter associação.

$\boldsymbol{G}$ - A lei deles é uma coisa, mas na lei do pessoal pobre podia ter feito uma coisa diferente. Se eu tivesse denunciado os caras, ficavam em cima. Eu não denunciei, o cara veio aqui pegou e foi embora, não deu nada, não teve confusão. Então a coisa tem que ser assim. Como com o pessoal do manejo, também não sei porquê mas eles falaram: entre vocês, o parque e a reserva tem que entrar num entendimento muito grande. Vocês têm direito, o parque é do parque e a reserva também é da reserva, e vocês tem que conversar e se entender. O entendimento é isso aí. Se vai fazer uma roça é porque precisa,

\footnotetext{
${ }^{233}$ Barraco ou rancho de pesca é uma moradia de trabalho típica dos pescadores da região e que são construídas perto da área de trabalho.

${ }^{234}$ Quilombo do Mandira é uma Reserva Extrativista Federal (RESEX) que também fica em Cananeia continental.

${ }^{235}$ Itapitangui é um bairro de pescadores que fica em Cananeia continental.
} 
eu vou lá e já falo que eu preciso fazer uma roça. Se eu vou pegar ostra é porque eu preciso disso daí. Então eles têm que nos entender e nós temos que entender eles também.

Nós mudamos para cá para trabalhar e desde o primeiro mês trabalhamos para o Hélio. Nós ficamos 18 anos trabalhando para ele.

I - Agora não porque depois que virou parque ele abandonou e não pagou mais nada.

$\boldsymbol{G}$ - Ele não pagou mais faz uns oito ou dez anos já. Ele fica dizendo que aqui é dele, mas eu falo para ele: olha o que você fez... Eu sou o empregado, mas não recebo mais e então no caso, eu é que sou o dono! E ele fica rindo para mim! Ele tem uma raiva de mim. Eu falo pode ficar, você não quis mais me pagar e me deixou dentro da área, como é que fica? E fica uma confusão danada.

Quando isso aconteceu, a situação no Retiro era a mesma. Não adianta mudar daqui porque lá no Retiro não muda muita coisa, então eu fico aqui. Se fosse para eu ir lá para o Retiro ter um trabalho e um salário eu iria correndo.

Hoje está difícil de trabalhar, difícil para todo mundo. Lá no Retiro se eles querem trabalhar e ganhar algum dinheiro, eles têm que tirar ostra, caranguejo, eles acham que lá não pode abrir nenhuma roça, nem para plantar feijão, porque e se sai uma multa em cima de um coitado? Hoje em dia é quanto uma multa por desmatamento? Se tivesse autorização, eu faria. Eu ainda faço umas rocinhas escondidas, mas pequenininhas!

I - Hoje em dia só ser for pequenininha, aqui no mato baixo.

$\boldsymbol{G}$ - Por ali eu plantei um pouquinho de rama ${ }^{236 !}$ Ah porque eles dizem que capoeira que é esse mato baixo não tem nada, que esse pode plantar direto. Eles dizem assim: Se você faz uma roça sem liberar e eles virem por cima, eles vão mandar direto uma multa!

É e isso fica complicado até para o pessoal que cuida da reserva, afinal vão pensar que eles deram aquele mato grande ali para desmatar. Aqui está dentro do Lagamar. Lá no Retiro é reserva, desde o rio para lá já está na reserva.

A reserva passa ali costeando a casa. Eles aumentaram a reserva. A mulher falou: vamos dar $2 \%$ e então ficou do rio para cá. Mas a casa ficou ainda no parque, então não aumentou nada! Se pegasse a casa e ficasse pra lá era uma boa, mas não. É porque então fica tudo por conta do Osmar ${ }^{237}$ que é reserva e não tem nada a ver com o parque.

\footnotetext{
236 Mandioca

${ }^{237}$ Osmar Pontes, gestor na RESEX Taquari e RDS Itapanhapima no período da entrevista.
} 
Agora o Mario Nunes ${ }^{238}$ diz: Você está no parque, mas a sua saída, o porto, já é reserva, então vocês estão na reserva. Então ele disse que nós temos que ser da reserva. Mas eu digo: eu sou da reserva mas a minha casa está no parque como é isso? Não teve jeito porque o aumento que eles deram não pegou a casa, pegou beirando ali. Então não sei.

Outra vez veio uma japonesa na reunião e só uma primeira vez aqui. Depois veio só as colegas dela e deu a mesma coisa. Foi nesse plano de manejo ${ }^{239}$ que me morderam doído porque na lei deles nada pode!

Diz que depois de cinco anos eles voltam para ver como está e se pode mudar, se pode pegar mais pesado. Mas eu digo que podia ser amanhã mesmo porque não vai mudar nada!

No plano deles de manejo não pode nem criar um cachorro, não pode fazer um desmatamento, aparece tudo. Essa história de roça, de plantar, não pode nem falar para eles. Então eu achei que pudesse dar uma mãozinha para as pessoas, não precisa pegar tão pesado, para não deixar trabalhar. Ou já mandasse eu sair de uma vez porque daqui a pouco eles vão dizer que eu não posso mais morar nessa casa.

Teve um que falou: que tal criar um boizinho lá para você ganhar um dinheiro. Mas não pode! Animal não pode criar! No plano não tem nem galinha!

Isso aí foi da reserva agora o plano de manejo que veio é que nem eu falo, eles trazem um livro e tudo concreto. Chega aqui já está valendo, tudo não pode porque já está no livro deles e não pode pular por cima. Eu acho que eu peguei o plano de uso. Eu acho que está lá em Cananeia numa pastinha que eu deixei lá.

Vir aqui eles vieram. Quer dizer aqui não vieram, mas vieram no Retiro, fizeram uma reuniãozinha lá. Até veio o pessoal do Marujá ${ }^{240}$, Ariri ${ }^{241}$... quem pôde ir, foi. Mas como eu digo, não adianta falar se eles já estão com a coisa feita. Então eles só conversaram o que era para conversar e o pessoal assinou, e disseram que depois iam ver, mas não teve depois. Eles dizem que não pode isso, não pode aquilo e a gente vai dizer o quê? O cara vem em cima, dizer que não podia fazer e como que eu fiz? Pode sair uma multa ou qualquer coisa em cima da gente.

\footnotetext{
${ }^{238}$ Mário José Nunes de Souza, gestor do Parque Estadual Lagamar no período da entrevista.

${ }^{239}$ Plano de uso. As unidades ainda não possuem Plano de manejo.

${ }^{240}$ Comunidade do Marujá fica na Ilha do Cardoso e é beneficiária da RESEX Ilha do Tumba.

${ }^{241}$ Bairro de Cananeia Continental.
} 
Eu tenho cinco filhos. Um está em Cananeia e tem quatro aqui. Eles estão trabalhando com ostra, no mar, porque com desmatamento ninguém fez mais para evitar confusão. Quer dizer, evitar multa. Você saiu daqui tem o porto e a reserva, então todo mundo trabalha para lá no mar, aqui dentro do parque ninguém faz nada. Só eu que faço... diz que é uma roça né? Mas se o cachorro deitar fica o rabo dele de fora! (Risos) Não dá para dizer que é roça porque quando você fala roça, as pessoas acham que é uma coisa grande. Mas já de medo de levar uma multa né? Porque se for uma roça grande, o cara passa aí por cima e ele vê claro, pois ganha para esse trabalho mesmo.

Eles apertaram muito para o mar e a parte dos fundos ficou parque.

Eles faziam roça no fundo, beirando o morro onde tinha lugar alto. Agora só deixaram lugar baixo. Eu não sei, eu fiquei invocado por eles falarem que ali na porta da casa dele não podia plantar, então não pode em lugar nenhum porque é aqui que ele mora! Onde ele vai plantar? Lá no fundo também é parque, então a reclamação da divisa foi essa.

Eu fiz uma rocinha daqui dá acho que dá meio quilometro, mas fica dentro da reserva. Eu passei a linha do parque e fiz na reserva. No tempo do Wilde ${ }^{242}$ ele veio e perguntou se eu tinha roça. Eu disse tenho, vamos lá. Fomos lá e depois quando nós chegamos aqui em casa de novo ele falou que a minha rocinha estava na reserva. E eu disse claro, porque a divisa é rio. Eu passei o rio e plantei para lá e estava na reserva. A divisa mesmo do parque é aqui, você passou o rio você está na reserva. Só que a linha do mar para lá que eu não sei direito onde pegou. Eles dizem que é duzentos ou cento e cinquenta metros. Acho que é duzentos metros da beira do mangue para dentro. Então aqui já é do parque. A linha da reserva, se aqui tiver um morro e o morro descer, eles acompanharam com a linha do parque e acompanharam o morro e fizeram uma cobrinha, mas não foi uma linha reta igual o grileiro fazia. O grileiro chegava aqui e largava uma linha onde batesse era ali! Agora o parque não, eles vieram fazendo cobrinha defendendo os morros porque no morro não pode fazer nada.

Antes a lavoura era feita onde dava bem, onde era bom, porque não tinha lei que impedia. Então piorou um pouquinho, que nem no Retiro, eu não sei se é falta de coragem, mas eles não plantaram mais nada. Também eles ali, Armando e Dirce, naquela idade não precisam plantar mais nada. Mas eles tinham que ter um trabalho para não

\footnotetext{
${ }^{242}$ Wilde Itaborahy, gestor na RESEX Taquari e RDS Itapanhapima no período da realização do plano de
} uso. 
plantar roça e ter mais alguma coisa para fazer, mas não surgiu mais nada. Ele acabou de plantar as mudas do projeto $^{243}$ ?

Eu não peguei as mudas para plantar. Eles vieram aqui mas eu falei do Hélio porque eu estava pegando pesado naquela época. Eu disse: Aqui é meu, mas aqui se for fazer reflorestamento e o Hélio diz que é dele, então vamos pedir ordem para o Hélio. Eles ficaram ali, conversa daqui, conversa dali, e teve um que falou que falou: não, você não se incomoda? Porque ele diz que é dele mas a terra é do Estado, do parque. E eu disse: mas que diacho que é isso que eu não entendo? Vem Hélio e diz que é dele, vem outro e diz que é do parque e o outro da reserva e Hélio não larga a mão, ele está todo mês me procurando em Cananeia para ajudar ele. Ele diz que não abre mão, que ele comprou, que ele pagou e é dele, mas será que esse homem não conversou com o pessoal do parque? Eu acho que faz uns trinta anos que ele comprou. Parece que no caso dele, ele não tinha título. Parece que ele foi fazer o documento porque ele só tinha uma declaração de posse que ele comprou, então foram ver ele não pagava nada. E se ele não paga nada é porque não tem documento, então o parque chegou e falou: Hélio tem que ir embora daí. Ainda fiquei pensando: mas por quê?

Isso faz uns dez anos, quando eles começaram com as reuniões. A primeira foi do parque. Foi com o Mario, esse Mario Nunes. E não era falando da reserva, era do parque. Como o pessoal reclamou muito, veio depois o comunicado em outra reunião: Vocês não querem ir para o parque, tem a reserva. O pessoal por aí está fazendo a reserva. Que tal uma reserva? O pessoal não entendia de reserva e depois de um tempo eu chamei o João e o Armando ${ }^{244}$ e perguntei para eles: que tal a gente aceitar essa reserva? Para parar com essa confusão ninguém estava aceitando nada, ninguém queria nada, daqui a pouco fica tudo para o parque e vai ficar mais pesado para nós. Então fomos nós três e quando chegamos lá o Mario abraçou porque ele estava esperando apoio. Ele disse que se nós três assinássemos já funcionava, e depois vieram mais pessoas.

Mas eles aqui, esse pessoal daqui dos Pontes não aceitaram. O pessoal do Nildo que trabalhava lá junto com eles, não aceitou. Eu não sei se ele está aí porque ele vem trabalhar uns dois dias e vai embora para Cananeia. Vem pegar ostra, pesca... outro dia

\footnotetext{
${ }^{243}$ Projeto de reflorestamento implantado na região pela organização não governamental The Nature Conservancy - TNT. As populações locais foram contratadas para plantar as mudas de plantas nativas que o projeto oferecia. http://www.tnc.org.br/ Acesso em outubro de 2016

${ }^{244}$ João Xavier e Armando Davi são moradores da RDS Itapanhapima e também são colaboradores deste trabalho de pesquisa.
} 
ele disse que queria fazer roça e que ia pedir autorização. Acabou não pedindo e não fez. também a roça! A casa dele aqui é naquele porto um pouquinho mais para frente. Do porto daqui é cem, cento e cinquenta metros. A casa na cidade é pegado ali com o Armando no Acaraú. ${ }^{245}$

O canal ficou do lado de fora da Reserva, agora o que eu não entendi bem foi o do fundo porque eu não sei até vai... Eles têm o mapa, mas por aqui eu não sei quem ficou com o mapa. Agora no plano de manejo eles deixaram um mapinha no Retiro, o Nivaldo ${ }^{246}$ deve saber. Se você pegar o mapa ali embaixo, está nossa casa e é a última. O meu nome está escrito embaixo. O Marco ${ }^{247}$ que escreveu um bocado de coisa, aquele que trabalha com o Osmar.

Agora o Mario é difícil de entender. Tem gente que quer falar pouco e por isso não dá para conversar muito e tem outros que são mais abertos... Ele não, ele parece que é mais fechado um pouco. O que ele fala tem que ser assim...falou, tem que ser. Nas reuniões ele conversa um monte, mas fora assim não. Ele tem cara de boa gente, mas na lei dele ninguém passa por cima, porque não pode, né?

Quando foram falar de aumentar a área da reserva, foi só $2 \%$. Era ali do rio e não pegou a casa ainda. Ficou no parque, então isso não adiantou de nada. Ficou só em papo. Se você pega do rio para cá, não adiantou. Para mim não adiantou de nada, se aumentasse $10 \%$ tudo bem, mas $2 \%$ não dá! Isso quem fez foi o pessoal do plano de manejo que veio lá em Cananeia.

Todo mundo chiou por causa da divisa mas disse que não tinha jeito. Porque se é para ficar na área, alguma coisa tem que fazer. Agora você anda um pouquinho e já é o parque e o pessoal vai ficar debaixo do mangue, e vai plantar o quê? Mas quem quer plantar também, porque quem não quer pode morar em cima da pedra (risos). Tem um bocado de gente ali na Ilha do Filhote. Um tempo atrás eles falaram que tinha uma área no Bom Bicho e que lá no Cardoso também tinha uma área. Eu disse: vocês procuraram um monte de área de pedra para morar em cima! E o cara ficou com uma raiva de mim! Eles moram ali há quase cem anos, o pai morreu morando ali e agora ficou os filhos $e$ eles não saem, então fiquem ali... Ali teve uma reclamação das famílias. No tempo de um padre que tinha aí, o padre João. Ele levou para o fórum, eles brigaram e então tiraram aquela área para eles. Mas ali fica no meio do mar, dá um pulo está na beira de lá. Então

\footnotetext{
245 Bairro na cidade de Cananeia.

${ }^{246}$ Nivaldo é um dos filhos do seu Armando e também é morador da RDS Itapanhapima.

${ }^{247}$ Marco é funcionário da Fundação Florestal.
} 
disse que aquilo ficou livre para eles trabalharem. Mas também em cem metros você está no parque. Então eu acho que eles entraram nesse entendimento, vocês ficam trabalhando dentro do parque. O padre João Ele era nosso amigo, quando acontecia qualquer coisa pesada aí no sítio a gente ia falar para ele. Você não sabia para onde levar, se levava na polícia, se levava no cartório. E como ele falava dava certinho, ele não mentia. Ele ajudou naquela briga de terra que o Armando já deve ter contado... Veio o Ademício que era um baiano e que casou com uma mulher aqui do Retiro. Ele andou rodando por aqui, ele tinha uma cara meio feia... Mas ele arrumou uma mulher aqui no sítio. Casou com a filha do João Alves, um cara que morava aqui no Retiro ${ }^{248}$. Então ele chegou, casou e foi lá para Cananeia. Depois ele fez um barraco de madeira para morar para cá. Ele era pobre mesmo, só depois fez uma casinha melhor. Daí foi indo, foi indo, e depois ele veio aqui no Retiro e começou a perguntar das terras: esse sitio é de vocês? Como é que é? E o João Alves disse que era dele porque ele morava lá há setenta anos, mas ele não tinha documento das terras, nunca fez documento. Mas você mora aqui, dá para fazer o documento, ele dizia. E o João falava que não ia mexer com essas coisas porque para não dava, porque ele era analfabeto. E ele falou se você quiser eu faço o seu documento e depois podemos até vender. E o baiano começou a insistir, até que um dia o João Alves falou que podia fazer o documento. Só que no cartório, o cara costumam fazer o documento da área inteira. Ele fez o documento da posse do João e saiu todo o sítio do Retiro. Ele não tocou em nós que morávamos lá. Ele fez do João Alves e passou um tempinho: ah o documento está pronto só falta vender. O João Alves deu para ele e quando a gente soube já estava vendido e estavam fazendo a divisão: Ah, o Ademício ele vendeu o sítio e vocês tudo junto! Nós não sabíamos o que podia fazer. Então eles queriam impedir todo mundo de trabalhar para a gente sair. Eles diziam: O homem vendeu aí, tem que sair.

O Ademício vendeu com a ordem do João Alves. Ele deu um jeito de pegar o João Alves para dar para ele a posse. Então ele fez já no nome dele. O João era analfabeto, não sabia de nada e o Ademício fez no nome dele como se o sítio fosse dele. Ele procurou uma firma lá fora que pagou metade para ele e mandou sair todo mundo. E foi aí que o padre João entrou. Nós ficamos sem saber o que fazer, e o padre João foi ao cartório e viu que estava tudo vendido. O Padre veio e disse: Eles venderam vocês todos! Ele foi lá e tentou impedir a venda, mas o cara já tinha vendido. Então foi aí que brilhou a

\footnotetext{
${ }^{248}$ Umas das áreas tradicionais que compõem a RDS Itapanhapima.
} 
estrela do padre João porque ele levou para o Fórum. Teve uns três anos de briga e eles entraram num acordo. Eles não ganharam porque já tinham feito o registro da terra. As famílias, Ademício e todo mundo teve que entrar no acordo para cada um ficar com um pedacinho de a terra. Mas ficou também para a firma porque ela tinha comprado e registrado. Está até hoje no nome dessa firma!

Ficou uma possezinha para as famílias. E o sítio, o resto era da firma. Só que a firma vendo do jeito que estava não montou serviço, então ficou para os posseiros porque eles já moravam nela. O João Alves fez uma casinha lá que era de madeira, até já caiu.

O Durvalino que era caseiro ficou com a casa que era da firma. A da firma era uma casa de material, parece que tem o telhado lá ainda.

Mas tem gente que não larga a mão, depois de ficar registrado, aquilo tem uma força enorme. O povo fala que o nome da empresa é Sulcar, mas eu não lembro... o Armando que ficou com os papéis, se você for ao fórum está lá o registro.

Depois eles desistiram, não veio mais ninguém. Depois passou uns dez anos e teve um que veio até aqui, e eu falei: Naquele tempo vocês brigaram e foi cancelado aquilo lá, mas se vocês quiserem brigar de novo eu estou pronto. Porque já era o filho do cara que tinha comprado e que tinha morrido. Veio o filho falando que queria brigar. Mas eu disse para ele que foi entrado num acordo para um não atrapalhar o outro. A firma não podia entrar e atrapalhar e nós também não podíamos atrapalhar a firma em nada. No fim não fizeram nada.

Eu estava junto, quando eles trouxeram bastante gente para abrir picada ${ }^{249}$ por lá. Eles queriam impedir todo mundo. Eles ficavam no porto, um bocado de gente enfezada, eles não queriam que ninguém entrasse. Até a gente quando passava eles falavam alguma coisa porque eles queriam que a gente revidasse.

Porque nesse caso se surgisse uma confusão e daquilo saísse uma briga, uma discussão, pode ser que os posseiros acabassem perdendo: Esse cara vai agredir o meu empregado e vai perder a razão.

A gente abaixava a cabeça e passava, mas foi feio. Eu digo que o parque nesse ponto entrou bonito porque agora de certo não entram mais! Não dá para vender, mas eu não sei se eles têm força nesse ponto aí. A não ser que essa firma, que era bem rica, está pagando algum imposto. É porque aí nos fundos o Alfredo lá do Taquari ${ }^{250}$ disse que não tem mais como tocar em nada, eles impediram tudo, e ele era forte aqui. As terras

\footnotetext{
${ }^{249}$ Caminho por trilha na floresta.

${ }^{250} \mathrm{Um}$ dos maiores proprietários da região do Taquari.
} 
dele ficam bem nesses fundos aqui. Mas para chegar lá tem que andar umas quatro horas ou mais pelo mato... Não tem nada picada, nem trilha. E não dá para ir pelo canal! Só a estrada do Ariri que corta aqui os fundos, se for por aqui, sai na estrada e de lá desce. Ah mas vai cansar as pernas para chegar à estrada!

Às vezes tem umas picadas de algumas pessoas que caçam, mas você tem que ir a olho. Antes quando eu podia andar bem eu saía às vezes para lá. Desce por aqui e vai andar uma três ou quatro horas para chegar na estrada e ir para o Ariri. Essa estrada é boa com o um bom tempo... seca porque é barro né?

Tem outra, se eles interessarem em ajeitar as passagens do rio ${ }^{251}$, até o Taquari é boa a estrada. Mas nunca se interessaram. Lá no Taquari eu não sei como ficou, não sei se é Reserva. É porque eles pegaram lá no fundo as terras de um pessoal.

Talita - Aqui tem a roda ${ }^{252}$, você vai ver! Ela que faz a farinha gostosa!

Isabel - Não faço para vender, só para comer mesmo! A roça é pequenininha.

Talita - Eu que cobiço a farinha dela... (risos)

Gentil - Para vender tem que plantar bastante. Fazer uma roça grande! E como eu falei, a roça que nós fazemos se um cachorro deitar o rabo fica para fora!

Talita - Não tem pressa, mas por causa da maré seca ele foi levar o barco lá embaixo, vai ter que andar até mais longe para chegar... é lama...

I - Eu vou de bota no mangue...

$\boldsymbol{G}$ - A gente gosta de morar aqui porque a gente é do mato, foi criado no mato.

I - As crianças têm vontade de ir para Cananeia, meu senhor, como querem ir embora! Rapaziada é assim....

$\boldsymbol{G}$ - Lá eu fico uma semana eu me sinto preso, aqui eu acordo eu vou ao porto, eu saio por esse caminho. Lá não, é só os trintas metros da casa, parece que você está preso! Se você saiu ali já tem gente olhando!

I - Ele vai lá e fica rodando o tempo inteiro! Ele sai, entra em casa de novo!

I - Ah os meninos querem, o meu filho Valdir não gosta de ficar aqui, ele quer ir embora para a cidade.

$\boldsymbol{G}$ - Lá pelo menos tem TV para ver mas aqui não. Aqui não tem $T V$... Ah a rapaziada tem espírito para isso!

Talita - Igual nós né? Até que animou um pouco a TV.

\footnotetext{
${ }^{251}$ A estrada do Ariri é cortada por inúmeros rios da região que, quando sobem em decorrência da chuva, isolam os moradores.

${ }^{252}$ Roda da casa de farinha.
} 
I - Eu trouxe a televisão mas trouxe só que com o DVD, estragou a luz. E ficaram brigando comigo falando que foi a TV que estragou!

Talita - Faz uns seis, sete meses que a energia chegou. Dizem que quando essa daqui completar um ano vai vir trazer outra luz que vai ser elétrica e vai funcionar chuveiro, e eles vão dar uma geladeira porque vai funcionar. Diz que lá no Paraná já tem.

$\boldsymbol{G}$ - Espero que não seja só conversa! E que não seja igual essa luz que está aqui porque se não vai ser a mesma coisa! Essa luz que tem aqui não dá nem para um freezer. A não ser que tenha aparelhagem só para ele, ou vai tocar um rádio ou alguma outra coisa, o freezer não aguenta.

Talita - Final do ano diz que vem, no Paraná já trocaram a bateria! Tem chuveiro, geladeira e para nós aqui é bom! Porque funciona a geladeira para não estragar as coisas que compra na cidade, não estragar a mistura. Para quem mora direto aqui é bom geladeira.

I - A gente vai sempre para Cananéia.

$\boldsymbol{G}$ - Eu vou de quinze em quinze dias eu vou lá.

I - Nossa casa é perto do Armando também.

Talita- Ali por perto é tudo uma família só.

I - Os meninos só vão de vez em quando para Cananeia porque eles trabalham aqui né?

$\boldsymbol{G}$ - Quando vão eles ficam oito, dez dias e estão voltando já! Lá não tem como ganhar nada, você leva o dinheiro daqui para gastar lá! Depois que gasta todo o dinheiro, aí eles vêm embora. Lembram da casa do pai! (Risos)

I - Eles já pegaram serviço lá na cidade e não quiseram ficar.

$\boldsymbol{G}$ - Os dois não seguraram lá. Eu não sei o que é que tinha que acabaram saindo.

I - Estavam na Miami ${ }^{253}$, trabalhar com peixe. Não gostaram.

$\boldsymbol{G}$-Trabalhar com o peixe acho que eles tinham que acostumar mais, porque tem a mulherada que trabalha e eles não aguentam? O que pegou mais no caso deles também foi o horário, eles perdiam horário. Muita gente que trabalha aqui mora lá em Cananeia. Mas na época que tinha as famílias aqui a gente juntava quatro, cinco, seis famílias e tomava um bocado de pinga, tocava viola a noite inteira e dançava! Por um ponto era bom, mas tinha uns que faziam besteira porque tomavam pinga demais, e quando

\footnotetext{
${ }^{253}$ Empresa pesqueira de Cananeia.
} 
amanhecia brigava. Eu dizia: isso não é coisa de gente... beber pinga e depois brigar... Era bom que não fizesse aquilo nunca! Mas por um ponto era bom porque pelo menos tinha algo, distraía e a rapaziada jovem gostava. Eu gostava bastante, mas quando começou acontecer essas brigas eu não coloquei mais os meus pés em nenhum lugar assim. O pessoal vai se morder lá e vai ficar nervoso. Uma vez lá na Ilha do Filhote eu fui, um cara quase matou o outro lá, eu saí de lá tremendo e eu disse: eu nunca mais volto! O cara veio bêbado correndo para pegar o outro, acho que ele tinha raiva dele. $O$ outro cara chegou no porto, pegou o remo e soltou na cabeça dele. O cara caiu em cima da pedra e ficou no escuro caído, e o cara que bateu pegou uma canoa e sumiu. Foi um susto, o pessoal pegou esse homem pela canela, pelos braços, fomos pegar o pulso dele e vimos que ele estava vivo. Então ele foi voltando, respirando mais fundo. Não morreu, mas ele desacordou e caiu lá, passou uns trinta minutos ele levantou-se e ficou tonto, então não deixaram mais ele sair. Abriu a cabeça do cara e quase matou, que coisa louca! Mas o pessoal bebe demais, tem uns que bebem normal, mas tem alguns que tomam demais e podem até matar os outros!

Nós somos católicos e no tempo do padre João ele fez uma capelinha ali no Retiro e a gente fazia missa lá. Mas as famílias foram indo embora e nós fechamos. Às vezes a gente vai na missa, mas aqui é difícil de ir toda semana. Mas para ser alguma coisa a pessoa tem que frequentar aquilo né? Se a gente não frequenta a igreja a gente não pode nem dizer que é católico! A gente foi batizado na igreja católica né? Os filhos também foram batizados lá. Os mais velhos iam na missa e os mais novos iam porque a gente leva né? Eles foram na escola do Retiro e estudaram até a quarta série. Na minha época era até a terceira, na deles era até a quarta, depois tem que ir para Cananeia estudar. A escola fechou porque não tinha mais aluno.

Meus filhos foram um dos últimos, depois tinha que ir para Cananeia. Mas a gente não tinha casa lá ainda e tinha que alugar e não tinha como né? E para ficar na casa dos outros depois tinha reclamação. Eles também tinham pouco interesse em estudar, dizem que não tem estudo que preste. Pelo menos saíram do analfabeto. Eu também fui até a terceira série, a quarta tinha fazer em Cananeia e eu não fui.

Aqui vender a pesca é difícil porque uma vez o rapaz pegou gelo, a gente não pegou o peixe e estragou tudo o gelo, aí nunca mais. Mas com o gelo também dá.

Meus filhos pegam ostra e caranguejo. O caranguejo não pode, era uma coisa que poderia ser liberada, eles viram que o caranguejo dá mais que a ostra e proibiram, isso agora, esses tempos. 
Eles trabalham mas até agora ninguém atrapalhou ainda, mas se eles vêm a polícia florestal eles vão prender. Eles têm que trabalhar e ficar esperto porque se eles pegarem eles levam.

Isabel - Aqui é a casa de farinha. Nós não usamos o gás, e tem tanta lenha pra cá que nós jogamos o bujão de gás e o fogão fora! Aqui só no fogo no chão! O bujão velho foi embora! Essa prensa é para secar massa de mandioca, você põe o tipiti e põe a coisa em cima e põe lá. Você rala um bocado de mandioca e aquilo fica tudo em água, aí fica que nem um lodo. Chama mandiquera. Então ali é tipo um cesto bem cheio, e você coloca em cima daquela mesinha e coloca bastante peso, ele vai pesando e vai baixando. Então escorre a água, quando você vê que está seco você tira dali e leva para o forno e seca num instante. Agora não aproveita o caldo mas parece que tinha um tempo que usava não sei para quê. Aí essa daqui é a roda, ela rala e vai caindo aqui em baixo. O cesto é ele que faz. Deve ter sido o pai deles que ensinou.

Eu me criei com a minha mãe lá no Taquari e ela fazia farinha. Ela trabalhava só com farinha. Sou nascida lá também. O Gentil ia para lá e a gente se conheceu, ele morava lá no Retiro. Ele ia lá na barra do Taquari. No tempo nosso tinha moça lá.... Assim eles iam lá também! Eles iam acampavam para pescar e depois vinham embora para casa. E tinha forró a noite. A Dirce casou primeiro com o Armando e veio para o Retiro. Eu casei já faz tanto tempo que eu nem lembro mais! A Creuza já está com trinta anos a minha filha mais velha. Casei na igreja e no civil. Mas não fizemos festa. Nós casamos e fomos embora para casa! Tinha gente que fazia fandango, mas nós não fizemos.

Isso, você coloca o tipiti na mesinha e ele vai baixando até secar a massa, e eu torro nesse forninho. Eu ponho aqui nesse foguinho no chão e vai mexendo até torrar. $O$ pilão é para arroz, quando tem arroz para secar né? De primeiro plantávamos sim, mas agora não plantou mais. Você viu os passarinhos ali?

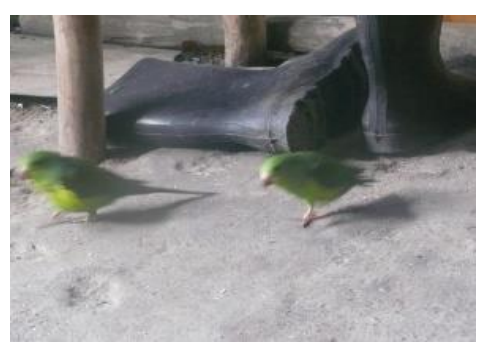




\section{Casa de farinha de Isabel}

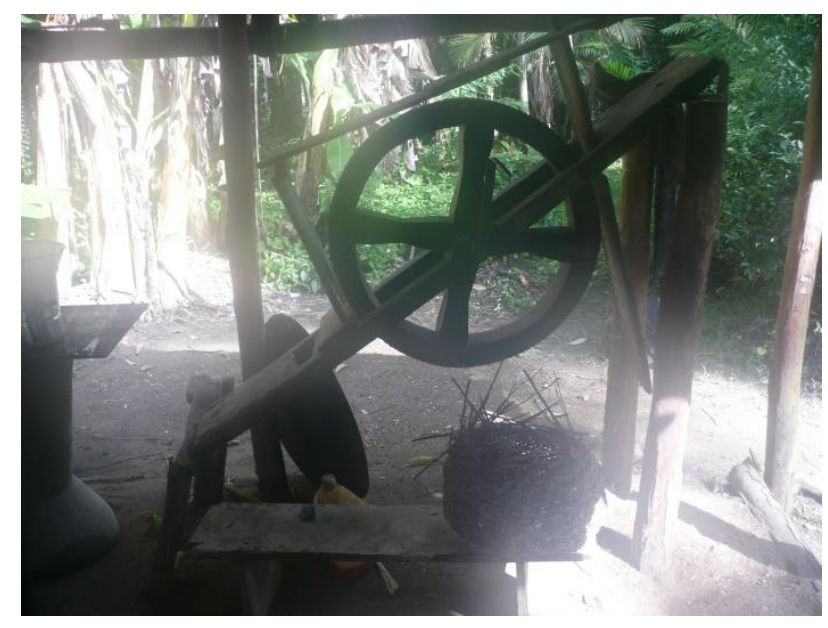

Acima, à esquerda: roda de moer mandioca; abaixo, à esquerda: fogão à lenha; à direita: peixes defumados.

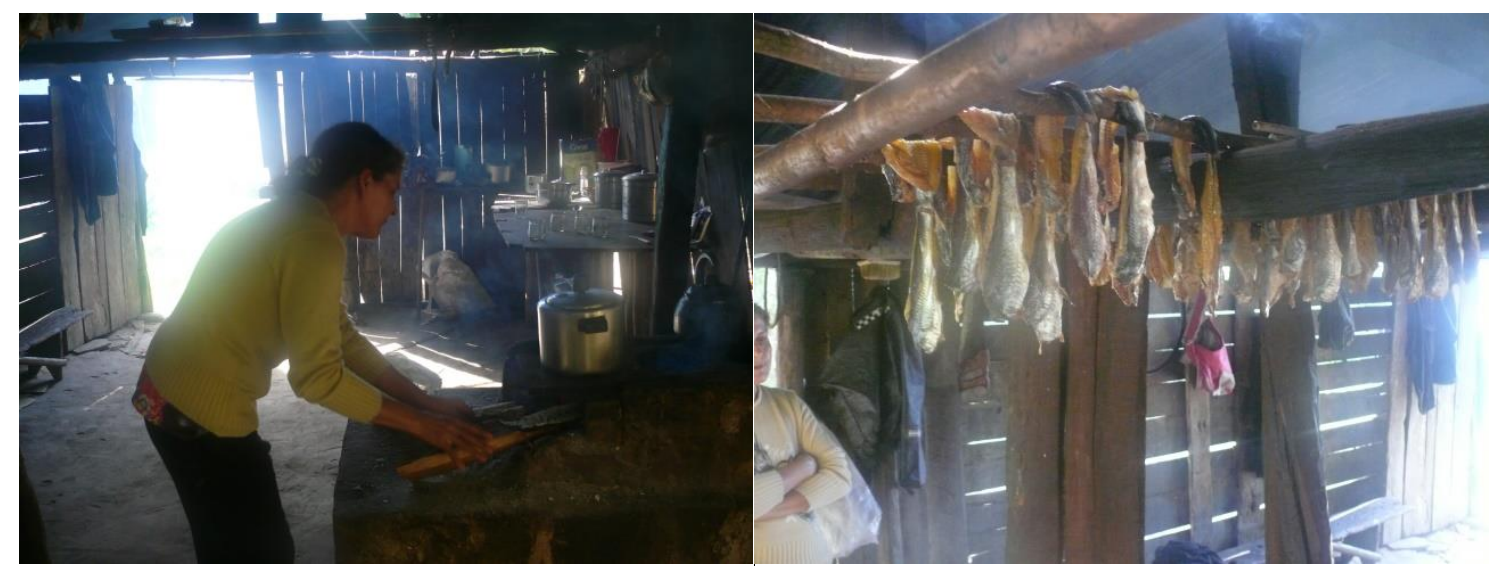

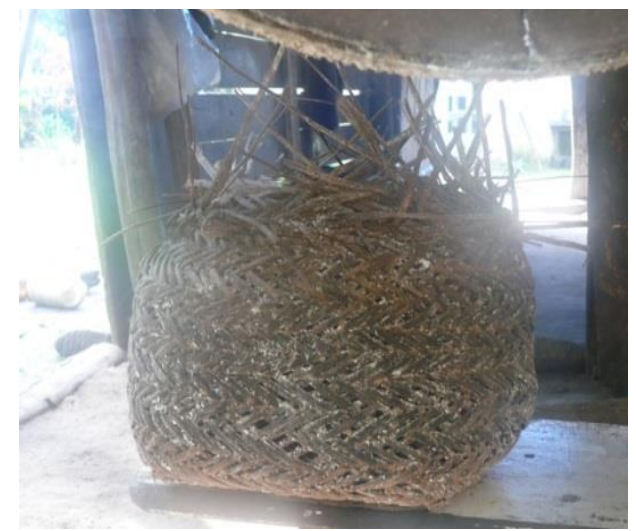

Tipiti

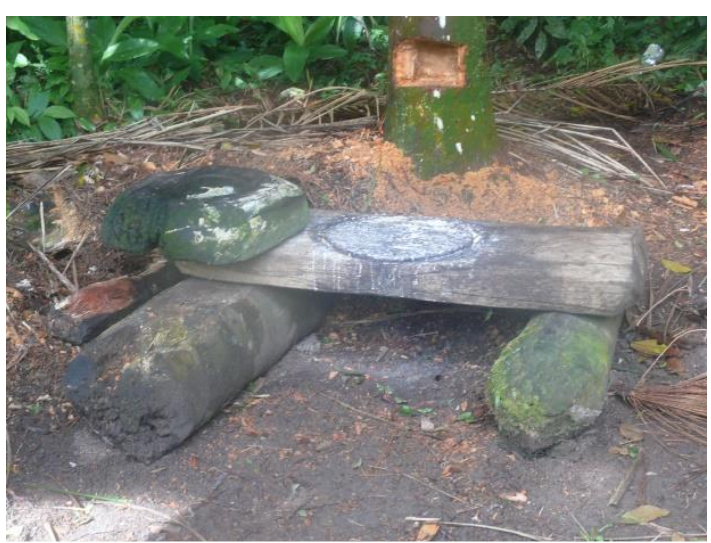

Prensa da mandiquera (massa de mandioca) no tipiti

Fotos: Cássia Milena Nunes Oliveira 


\subsection{Unidades de Conservação Sustentáveis: Construção autoritária e conflitos.}

O senhor Gentil foi o colaborador mais arredio de todo o trabalho de campo. Por meio de sua narrativa, podemos compreender que parte dessa postura explica-se pela forma como ele percebe a ideia de unidade de conservação, tanto o "parque" quanto a "reserva". Como morador do bairro Retiro, ele identifica duas fases de implementação da legislação ambiental pertinente às unidades de conservação na região. A primeira corresponde ao período de maior repressão e violência decorrente da criação do Parque Estadual da Ilha do Cardoso. Essa unidade de proteção integral criada em 1969 encontrase geograficamente próxima à RDS Itapanhapima e constitui parte da área de trabalho dos moradores. A segunda fase é a implementação da Reserva de Desenvolvimento Sustentável Itapanhapima associada a um período de promessas de que a presença do Estado na área não se daria apenas pela repressão, mas pela implementação de projetos sustentáveis e viáveis para a área que seria ambientalmente protegida. Segundo ele, a reserva foi uma alternativa aceita diante da ameaça de sobreposição de seu território pelo Parque Estadual Lagamar. A ideia de reserva parecia uma solução não ideal, mas que ao menos permitiria sua permanência. Além disso, a reserva apresentava um horizonte de trabalho pelos projetos sustentáveis que poderiam se desenvolver, mas não foram implementados. Para ele, a Fundação Florestal convenceu a ele e seu irmão Armando que aceitar a reserva seria um caminho para que as demandas locais fossem atendidas, o que posteriormente não aconteceu. Assim, segundo sua perspectiva, a Fundação Florestal propõe alternativas, mas não apresenta a estrutura para que os projetos se realizem, como no caso da criação de abelhas. Ele ressalta que tal atividade seria praticada por ele pela primeira vez e que, portanto, não possui conhecimentos (e recursos financeiros) para que pudesse começar e manter o empreendimento. Demonstra disposição, mas alega não saber como trabalhar dentro da lógica do órgão gestor e, portanto, este deveria investir na formação técnica e fornecimento de estrutura de forma a "criar um trabalho que não precisasse fazer desmatamento". Outra crítica se remete à forma como o plano de uso, chamado por ele de plano de manejo, foi elaborado. Ele acredita que o documento é uma mera burocracia que já veio pronta e baseada apenas nas leis do Estado, posto que suas demandas e dos demais beneficiários não foram satisfatoriamente cumpridas. A legislação das unidades de conservação sustentáveis prevê que se realize um plano de uso 
e posteriormente um plano de manejo para a área demarcada. Esses dois projetos de diagnóstico e uso sustentável, segundo a premissa legal, deveriam ser elaborados em conjunto com a população local. Porém, apenas o plano de uso foi realizado, e conforme evidenciado pelas narrativas e pelo pouco tempo dedicado a sua elaboração, trata-se de um documento de diagnóstico e de caracterização da área, além de buscar a identificação dos principais conflitos. Ainda que esse plano de uso aponte determinadas deficiências do processo de demarcação da área, ele não apresenta soluções ou encaminhamentos para as questões apresentadas. Nem ao menos chega a sugerir claramente a necessidade de revisão do espaço destinado à comunidade para que ela consiga reproduzir plenamente seus costumes culturais, como a produção de farinha de mandioca. No momento das entrevistas, fica claro que os moradores têm pouco acesso à condução do processo burocrático de uma possível revisão do espaço destinado aos moradores. Espaço sobre o qual existe uma memória afetiva, de uso e pertencimento que não foi levada em consideração no momento da demarcação.

Como podemos constatar pelas narrativas, as restrições ao uso da terra geram a maior parte das insatisfações dos moradores da RDS Itapanhapima, assim como na RESEX Taquari. Além da proibição do uso da coivara, as áreas destinadas ao plantio não são suficientes ou não apresentam características físico-geográficas compatíveis com as suas tradicionais culturas agrícolas como milho, feijão e mandioca. No caso de Gentil e Isabel, a produção de mandioca ocorre em uma pequena área afastada, o que proporciona uma certa quantidade de farinha para o consumo da família, com a utilização de técnicas e instrumentos tradicionais como a roda, a prensa e o tipiti. Dessa forma, o aumento da área da reserva é a solução por eles proposta para viabilizar a agricultura na área. Em relação a isso, o problema do senhor Gentil deixa ainda mais claro a falta de cuidado, por parte da equipe técnica, quanto aos rearranjos territoriais que garantissem a existência do Mosaico (MOJAC): a divisa entre a área do Parque Estadual Lagamar e a RDS Itapanhapima se localiza praticamente junto a sua casa. Esta casa, uma das únicas construídas com tijolos na área, era a moradia destinada ao caseiro de uma fazenda na área, cujo proprietário é identificado apenas como Hélio. Essa fazenda foi desapropriada pelo Estado e o proprietário deixou de pagar o devido salário a Gentil, que se apropriou da casa onde vive até hoje com a família.

Em relação à pesca, no caso de Gentil e Isabel (e também de outros colaboradores), a distância da cidade de Cananeia e a dificuldade de transporte, aliada ao fato de não possuírem energia elétrica capaz de suportar um freezer (e nem o próprio 
freezer), inviabilizam que a produção seja vendida na cidade. Portanto, as principais atividades econômicas da área são a roça e a coleta de ostras. Estas últimas podem ser comercializadas porque atraem empresas atravessadoras, que compram a produção local a um custo baixíssimo e a revendem, sobretudo em São Paulo. $\mathrm{O}$ atravessador mais antigo e constantemente citado pelos colaboradores é Jacques, dono de uma empresa, a Jacostra. A empresa regulamentada é a opção de venda, já que os moradores locais não possuem a estrutura exigida pelo mercado e pelo governo federal e estadual para circular sua mercadoria. Dentre as maiores exigências destacadas, estão a máquina depuradora, responsável pela limpeza das ostras, e as licenças e registros de venda e circulação emitidos pelo Estado por meio do SIF (Sistema de Inspeção Federal). Nossos colaboradores demonstram se sentirem explorados por essa relação estabelecida com o atravessador de sua produção, na medida em que possuem consciência de que os valores pagos são bem mais baixos do que os valores de revenda do produto pela empresa.

Como já mencionado, a legislação prevê que a gestão das unidades de conservação sustentáveis deve ser realizada de forma compartilhada, ou seja, em parceria com os beneficiários. Assim, segundo o SNUC:

\footnotetext{
Artigo 18

$\S$ 2 A Reserva Extrativista será gerida por um Conselho Deliberativo, presidido pelo órgão responsável por sua administração e constituído por representantes de órgãos públicos, de organizações da sociedade civil e das populações tradicionais residentes na área, conforme se dispuser em regulamento e no ato de criação da unidade.

Artigo 19

4ำ A Reserva de Desenvolvimento Sustentável será gerida por um Conselho Deliberativo, presidido pelo órgão responsável por sua administração e constituído por representantes de órgãos públicos, de organizações da sociedade civil e das populações tradicionais residentes na área, conforme se dispuser em regulamento e no ato de criação da unidade. ${ }^{254}$
}

A gestão das duas unidades é incumbida a um único gestor, que dessa forma promove conjuntamente as reuniões do Conselho Deliberativo Gestor. As primeiras reuniões ocorreram em 2011, dirigidas pelo gestor Osmar Pontes após a elaboração do plano de uso. Como já mencionado, a participação dos beneficiários era oscilante, sendo

${ }^{254}$ http://www.planalto.gov.br/ccivil_03/LEIS/L9985.htm Acesso em janeiro/2017. 
muitas vezes irrisória. Em alguns encontros, nem mesmo os conselheiros (representantes das unidades de conservação) compareciam, o que inviabilizava a tomada de decisões pela falta de quórum. No início desta pesquisa, as reuniões ocorriam a cada dois meses, e diversas estratégias foram testadas pelo gestor a fim de garantir maior participação dos beneficiários, como a mudança do local ou do horário. Entretanto, tais medidas não surtiram o efeito esperado, e as reuniões continuaram pouco frequentadas e mantendo sempre os mesmos participantes. A chegada da nova gestora Nathália Balloni, em 2015, dinamizou os espaços de discussão, posto que respostas, mesmo que nem sempre positivas, passaram a ser emitidas com maior rapidez. Além disso, ela aumentou o número de reuniões, que passaram a ser mensais, e criou grupos de trabalhos específicos, chamados de Câmaras Temáticas (CT), como o CT da Madeira e CT da Pesca, voltados para discutir as demandas dos beneficiários e esclarecer a legislação pertinente em cada caso. No entanto, é preciso ressaltar que, ainda que seja nítido o esforço em busca de uma solução para as questões apresentadas pelos beneficiários, os gestores enfrentam a falta de estrutura da Fundação Florestal para realizar vistorias e trabalhos técnico-burocráticos. Quando essa pesquisa se iniciou, o gestor contava com um funcionário da Fundação Florestal e um funcionário terceirizado que, embora contratado como monitor ambiental, realizava as mais diversas funções, como visitas de fiscalização, registro de atas, entrega de comunicados para as reuniões, etc. No final de 2016, o governo do Estado limitou o número de contratações terceirizadas e o "monitor" foi demitido. A escolha de qual unidade perderia um funcionário foi realizada pela diretoria local da Fundação Florestal em Cananeia, que também é responsável pela gestão do Parque Estadual da Ilha do Cardoso (PEIC), pelas três unidades de conservação de uso sustentável existentes na cidade (RDS Itapanhapima, RESEX Taquari e RESEX Ilha do Tumba) $e$ pela Área de Proteção Ambiental Marítima do Litoral Sul.

Diante desse quadro institucional e a partir do exposto pelas narrativas e pelas observações de campo, foi possível constatar que o espaço político representado pelo Conselho Gestor Deliberativo não se constitui, para os beneficiários, como um canal capaz de solucionar os conflitos. Segundo as evidências presentes nas narrativas, interpretamos que isso decorre de alguns fatores:

- O contexto de criação das unidades de conservação de uso sustentável colocou beneficiários e agentes públicos em uma situação de confronto. Isso se deu principalmente pelo fato de que a proposta de regulação do território, pautada pela legislação do SNUC, 
não partiu de uma demanda das comunidades locais, e sim como parte do projeto de criação do Mosaico de Unidades de Conservação do Jacupiranga (MOJAC).

- Os direitos vinculados à tradição dos beneficiários foram, em sua maioria, negligenciados e reprimidos pelo Estado durante a implementação da legislação ambiental proibitiva, entre os anos de 1970 e 1990. No período seguinte, sobretudo a partir dos anos 2000, a criação do SNUC e da Política Nacional de Desenvolvimento Sustentável dos Povos e Comunidades Tradicionais inseriu esses beneficiários numa esfera institucional orientada pela necessidade de participação política. Entretanto, salvo algumas exceções, como Carlos França, os beneficiários foram alocados como parte desse processo político sem que possuíssem qualquer experiência anterior ou fossem devidamente orientados sobre como realizar tal função. Sem o devido conhecimento formal exigido pelas diretrizes e leis que regem as unidades de conservação, os beneficiários não acreditam ser possível acessar seus direitos. Dessa forma, a Fundação Florestal se mantém, para esses colaboradores, como uma instituição responsável pela repressão do Estado, e as unidades de conservação continuam sendo os espaços em que nada pode ser feito. $\mathrm{O}$ medo das multas impede iniciativas e o pedido de licença não parece ser viável devido à burocracia e à demora para a obtenção de respostas.

- As práticas repressivas realizadas pelos órgãos do Estado, como a Fundação Florestal e a polícia militar, promoveram no passado uma interrupção temporal e cultural de práticas econômicas, em especial agrícolas. Dessa forma, a mudança legislativa não foi capaz de promover a retomada dessas atividades, e por isso poucos moradores acessam o conselho para a obtenção de licenças.

- Algumas das demandas dos beneficiários não podem ser resolvidas diretamente pelo órgão gestor, tais como: a revisão e ampliação da área da reserva, a permissão para praticar a coivara e para o plantio em áreas onde a vegetação já se encontra em estágio avançado de regeneração (o gestor apenas pode autorizar roças no caso de áreas de vegetação baixa e que já eram utilizadas para esse fim) e a melhora na estrutura dos bairros em relação as estradas, o transporte público, escolas, postos de saúde, etc. 


\section{4 - Unidades de Conservação e a reinvenção do cotidiano.}

As histórias de vida até aqui apresentadas narram experiências ressignificadas no presente e que em grande parte expressam a sensação de injustiça e violência vividas por nossos colaboradores. Grande parte dessa violência é identificada como uma ação unilateral do Estado que intervêm e transforma o cotidiano, dificultando a sobrevivência econômica e agredindo culturalmente as populações locais. Entretanto, ainda que se pretendam totalizantes, as estruturas de dominação não suprimem as novas formas do fazer a vida, ou seja, a emergência de iniciativas que buscam recriar a sobrevivência e os processos sociais reconstruídos no cotidiano. Segundo Certeau:

Se é verdade que por toda a parte se estende e se precisa a rede da "vigilância", mais urgente ainda é descobrir como é que uma sociedade inteira não se reduz a ela: que procedimentos populares (também "minúsculos" e cotidianos) jogam com os mecanismos da disciplina e não se conformam com ela a não ser para alterá-los; enfim, que "maneiras de fazer" formam a contrapartida, do lado dos consumidores (ou "dominados"?), dos processos mudos que organizam a ordenação sócio-política. ${ }^{255}$

Essas narrativas denotam portanto, a construção de processos de resistência elaborados na experiência do vivido e que demonstram como nossos colaboradores criaram estratégias que possibilitaram o enfrentamento dos novos dilemas impostos pelo contexto em que foram inseridos pela implementação das unidades de conservação. Dessa forma este capítulo apresenta algumas das iniciativas que foram criadas nestes espaços de forma a reconstruir o cotidiano e possibilitar novos projetos de vida. Para tanto, selecionamos duas narrativas que expressam o olhar crítico dirigido ao passado e ao presente, mas também vislumbram saídas de forma a não se resignar aos limites impostos pelo mundo em que vivem. Demonstram portanto o caráter dinâmico desses grupos sociais e a reinvenção de suas relações com o território, promovendo um rico diálogo em que tradição e modernidade se confrontam e delineiam novas críticas e possibilidades.

${ }^{255}$ CERTEAU, Michel de, A invenção do cotidiano, 15ed., Petrópolis, RJ: Vozes, 2008. p.41 


\section{$\underline{\text { Adelmo Davi Pontes }}$}

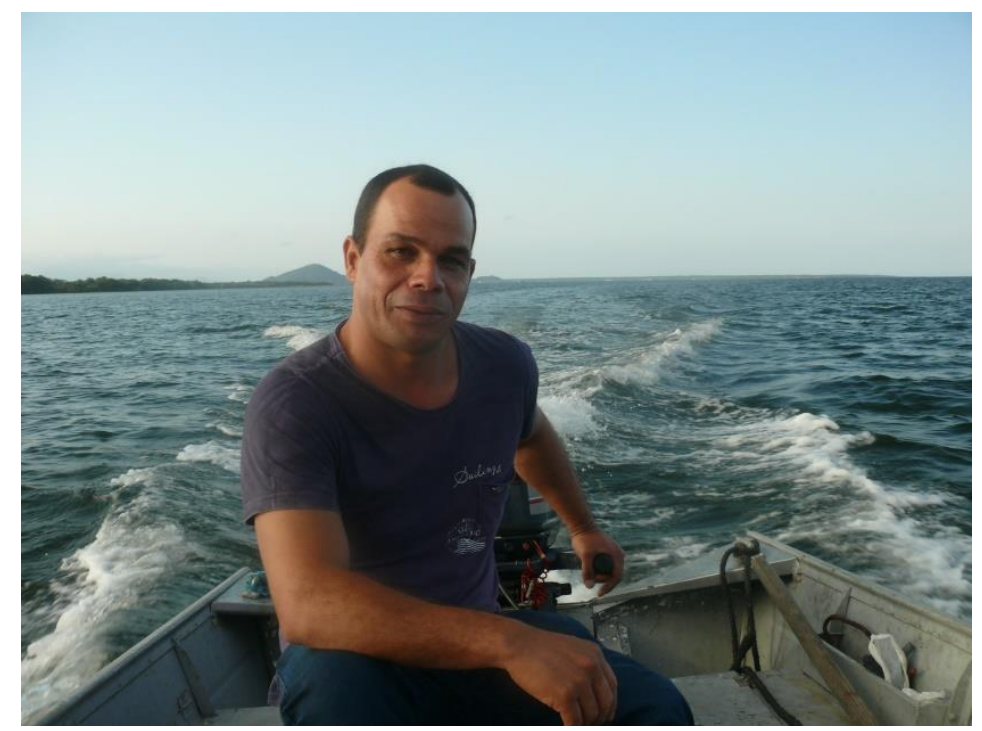

Adelmo é beneficiário de RDS Itapanhapima e um dos filhos de Armando e Dirce. Segundo relatos do gestor Osmar era um dos beneficiários que mais claramente demonstrava resistência à implementação da unidade de conservação sustentável em seu território. Incentivado pelo gestor, ele realizou um curso de formação e foi contratado de forma terceirizada como guarda-parque do Parque Estadual da Ilha do Cardoso (PEIC). Graças a proximidade estabelecida com a Fundação Florestal, tornou-se um dos membros mais atuantes do Conselho Gestor Deliberativo das unidades de conservação. Em relação a este trabalho de pesquisa foi um dos colaboradores com quem mais estabelecemos contato, sendo também o facilitador do acesso ao sítio de seus pais na RDS Itapanhapima. Entrevista realizada em agosto de 2015.

Então, fica a pergunta: porque as coisas são determinadas dessa forma, que torna tudo tão difícil para nossa sobrevivência?

Adelmo

Meu nome é Adelmo Pontes David, filho de Dirce Pontes David e Armando Pereira David. Minha esposa se chama Rosana Moraes Pontes; tivemos quatro filhos: o mais velho se chama Adelmo Pontes David Junior, depois nasceram o Douglas David Pontes, o Evandro David Pontes e o caçula, David Lucas, que tem um ano e dois meses. São quatro filhos... é que não tinha televisão lá onde eu morava! 
Para falar a verdade eu morei em vários lugares, dependendo da situação, nos deslocamos várias vezes. Já cheguei a morar próximo do Marujá, por causa das dificuldades, e arrumei trabalho como caseiro para um senhor chamado Ribas. O cara gostou do meu trabalho, mas mesmo assim em pouco tempo comecei a trabalhar para o senhor Eduardo Melão ${ }^{256}$, que é um homem muito conhecido na região. Mas foi por um curto tempo. Logo depois voltei de lá e voltei para o sítio, porque a gente não esquece o sistema da gente e lá era muito preso e não fui criado daquele jeito, sem liberdade, sem poder sair. Caseiro vive muito fechado, e por isso acabei voltando para o sítio.

Eu saí do sítio onde morava com meu pai porque tem hora que as coisas travam e eu não conseguia uma renda boa para viver, a vida estava muito difícil.

Não morávamos na casa onde meu pai mora atualmente; morávamos em uma casa que ficava acima da trilha, que eu acho que nem existe mais, a uns três quilômetros de onde meu pai mora hoje em dia, perto da nascente da cachoeira. Só que lá era difícil também. Éramos crianças quando moramos lá, tínhamos eu acho, uns cinco, seis, oito anos de idade. A gente ia para a escola, sem tênis, sem bota, saíamos muito cedo... Lembro como se fosse hoje... às vezes nem chinelo não tínhamos para calçar... Sinceramente, era muito difícil mesmo, mas a gente tem que contar a verdade...

A gente passava por lugares difíceis de passar, era brejo, muito ruim, tudo madeira, molhava o pé, não tinha como secar, chegavam a ficar vermelho de frio! Hoje não faz frio mais lá, mas naquela época fazia bastante. Um frio imenso, meu Deus! Era realmente muito difícil enfrentar tudo aquilo... Nossa infância foi difícil, papai era sozinho, e éramos dez irmãos para ele cuidar. Naquela época era permitido plantar, cultivar roças, mas nem isso nos ajudava muito, afinal demorava muito tempo para a plantação dar frutos, demorava muito para poder fazer a colheita, e éramos muitas bocas para se alimentar do pouco que conseguíamos colher.

Por exemplo, ele deixava de ganhar dinheiro de forma mais rápida para fazer roça. Mas na roça é preciso quase um ano para poder colher mandioca! Arroz, que é mais rápido, mesmo assim leva seis meses! Eu acho que por isso que logo percebi que não queria o mesmo para minha vida, e tentei seguir por outros caminhos: eu não consigo ficar esperando seis meses, ou até mais, para fazer uma colheita que nunca era suficiente para tanta gente da família poder comer!

\footnotetext{
${ }^{256}$ Ex-deputado estadual e veranista na Ilha do Cardoso, área de Parque Estadual.
} 
Naquela época eu ajudava na lida com o cultivo, lembro que cortava palmito... afinal era aquilo que tinha, né? Não tinha como fugir.... Era também uma tradição do pessoal que vivia nessa região, era possivel vender uma parte da colheita, e sempre havia quem comprasse... Era como uma lei da natureza, não havia opção, outro modo de levar a vida, mesmo com tantas dificuldades. Para o corte do palmito, desde que a gente tinha uns 13, 14 anos, nós íamos com ele para ajudar. Cortávamos o palmito e trazíamos pra casa nas canoas, remando... Mas já era uma atividade proibida, pelo que me lembro sempre foi. Só que tinha um senhor, dono de uma fábrica em Cananeia, que tinha uma máquina de transporte e conseguia o documento para poder fazer o transporte da mercadoria. O nome dele era Paulinho Micachessi, já falecido.

Todo o pessoal daqui todo mundo conheceu o seu Paulinho. A vigilância sanitária muitas vezes chegou a abordá-lo, mas ele sempre tinha as guias, os documentos, que ele obtinha tudo certinho, dentro da lei.

Muito de nós, da nossa gente, vendia para ele, pois a fábrica dele era justamente de palmito. Ficava aqui no centro da cidade, mas isso já faz muito tempo. Parece que ele também não conseguia se manter. Ele comprava da gente, de vários de nós, e sempre ia pagando certinho, mas com o passar do tempo, chegou uma hora que não tinha mais dinheiro para pagar ninguém, então acabou falindo. Foram chegando outros de fora, além das autoridades que começaram a aplicar multas no seu Paulinho..., e a "casa foi caindo”, ele já não conseguiu se manter. Ele morreu pobre, não sobrou nada, só ficou com a casa onde morava. Mais nada. A viúva dele herdou os processos e muitas dívidas para pagar.

Atualmente tenho 37 anos de idade, nasci em 1978. A maioria de nós adquiriu e cuidou de tudo isso aqui. Quando eu vim para cá para trabalhar aqui o que a gente fazia era isso: cortar palmito, vender palmito, para poder sobreviver...

É para isso a gente vai, fica no mato, faz acampamento, fica lá, enfrentando calor, bichos, mosquitos... as vezes o calor era tanto que alguns de nós aguentava no máximo três dias, além do que o palmito também começava a estragar. No inverno, dava para aguentar uns quatro dias, até porque o palmito aguenta mais no frio antes de começar a estragar depois de ser coletado. Com o tempo, cada vez mais e mais pessoas se dedicavam a essa atividade, e precisamos nos adaptar a isso. Surgiram algumas inimizades grandes, por que quando uma pessoa começa a trabalhar com o palmito ela não é muito conhecida, é preciso algum tempo para se tornar conhecido no ramo, além 
do que tem uma equipe trabalhando junto... e não é só você, são muitos, e só assim que cada um vai conhecendo pessoas que trabalham com a mercadoria, entendeu?

Os desentendimentos eram na maioria com os guarda-parque, eles eram nossos piores inimigos. Os caras eram guardas, nós não entendíamos que eles estavam fazendo o trabalho deles. Para nós, eles estavam errados em tudo, apenas nos perseguiam e víamos isso como uma coisa muito ruim, né?

Eu mesmo achava que eles estavam sempre errados, pura perseguição, porque ninguém ajuda ninguém... era como eu pensava na época...

Porque de fato parece que a lei não servia para ajudar ninguém. Lógico, a lei existe, não foram os guardas que a fizeram, e eles diziam que estavam apenas cumprindo suas funções de seguir o que diz a lei. Hoje eu entendo melhor tudo isso, só que antes eu sinceramente não entendia não.

Pensava assim: tem o nosso lado, né... a região virou parque, virou reserva, até aí tudo bem. Mas nós recebemos uma promessa, que iriamos receber uma indenização. E não foi qualquer pessoa que falou! Foi um deputado que nos disse! Eu não lembro o nome dele exatamente agora. Mas foi ele que falou que nós iríamos receber uma indenização, entendeu? Então, poxa, como faz isso, eu nasci naquele lugar. Eu e meus irmãos, nós nascemos lá. A lei tem que valer para a o nosso lado também, né?

Ai uma pessoa vem, e faz o negócio do jeito dele, entendeu? E nós como ficamos?

Lembro perfeitamente como foi. Eles simplesmente anunciaram que a partir daquele momento tudo isso passaria a ser uma reserva. Mas nos informaram que seriam demarcadas as áreas com a colaboração dos usuários, ou seja, nós. Mas não foi assim: eles vieram no avião, fizeram mapas aéreos, sem nem saber os locais que eram usados para roça, para o cultivo, para nossa sobrevivência. Ainda hoje, meu pai que está lá, meus irmãos, eles não conseguem autorização para fazer sequer uma canoa com as madeiras que têm lá, entendeu? Porque não existem árvores se não for nos morros. As árvores para fazer canoa você só consegue nos morros. Será que vai causar danos na natureza se no meio de cinquenta árvores, você tirar uma só? Ou duas, que seja? Então eu acho que isso é uma coisa bem mal estudada. Noutro dia eu estava na escola ${ }^{257} e$ assistimos um vídeo em que o pessoal caiçara daqui, vai derrubar uma árvore. Então um senhor que aparece no vídeo falou que a árvore tinha cinquenta anos, disse que era um especialista e podia assegurar isso. Ele falou: "essa árvore aqui, ela iria morrer, tem

${ }^{257}$ EJA- Educação de Jovens e Adultos. 
que derrubar". A árvore foi, então, cortada com motosserra. E pudemos ver o miolo da árvore. O senhor que aparecia no vídeo então explicou: "viu só, ela estava secando já". E estava mesmo! Mas a questão é: quem de nós, caiçaras, vai explicar isso para as autoridades? Aquela árvore já estava condenada, sem vida. Como essa, quantas mais estão ali, ou caídas no meio do mato ou prestes a cair? Mas a lei determina: é área do parque, então não pode mexer! Então, fica a pergunta: porque as coisas são determinadas dessa forma, que torna tudo tão difícil para nossa sobrevivência? Nós nascemos no meio daquilo tudo, fazendo as coisas dessa maneira, entendeu? E a lei como foi feita só aumenta nossas dificuldades.

A área da $R D S^{258}$ foi delimitada apenas na beira dos morros... É praticamente uma área formada só de restinga, e os morros todos estão protegidos pela área delimitada pelos Parques. E é dos morros que poderíamos extrair recursos para nossa sobrevivência.

Ou seja: todas as áreas dos morros ficaram protegidas dentro do parque ${ }^{259}$. O Osmar $^{260}$, que responde pela RDS, não consegue fazer nada a esse respeito pois isso não depende dele.... o Osmar não consegue dar qualquer ordem que mude essa regra.

Eu mesmo só consegui autorização para fazer canoa lá no parque da Ilha do Cardoso, que é uma área muito mais fácil para conseguir esse tipo de liberação das autoridades. A autoridade responsável chegou a assinar a autorização, o pessoal do conselho inclusive a aprovou, mas eu nem cheguei a retirar, porque nessa época eu me mudei de lá. Mas de toda forma eu consegui a autorização, o que nem sempre é fácil.

Tenho para mim que aqui a dificuldade é maior, por que diferente do parque lá da Ilha do Cardoso, onde tem muito mais madeira, muita madeira já caída, nessa região não tem mesmo tanta madeira, principalmente já caídas. Talvez se tivesse, a autorização e a liberação fosse mais fácil. Claro, também depende muito de cada um de nós, da nossa insistência. As pessoas que realmente precisam e querem fazer canoas para sua sobrevivência, tem que pegar no pé das autoridades, bater em cima. E se a autorização não vier de jeito nenhum, cabe às autoridades arrumar outra solução, tomar outra providência, como por exemplo disponibilizarem a quem de fato precisa uma embarcação de fibra, de metal, ou do que for, desde que ela chegue até o morador que faz a solicitação. No Conselho sempre nos dizem isso, mas o problema é que tudo isso é

\footnotetext{
${ }^{258}$ RDS Itapanhapima.

${ }^{259}$ Parque Estadual Lagamar que faz fronteira com a RDS.

${ }^{260}$ Osmar Pontes, gestor da RDS Itapanhapima e da RESEX Taquari e Ilha do Tumba.
} 
muito demorado e depende de muita insistência, o que faz com que muita gente acabe desistindo, e se acabar usando a madeira tirada da área de proteção, correm o risco de serem multados e punidos.

A maioria dos meus irmãos, por exemplo, já saíram dessas áreas de proteção, ficou difícil mesmo a sobrevivência e garantir o sustento. Atualmente quem está lá é o Nivaldo e também o Eliseu.

O Eliseu, por exemplo, saiu de lá, mas voltou. Na verdade, ele está o tempo inteiro indo e voltando, mas podemos dizer que sim, ele está lá. Ele chegou a fazer umas canoinhas. Dia desses, até deu uma para o meu filho. Era feita de madeira, a caixeta, que ele usa com autorização porque tem na restinga, fora da área de proteção. Para esse tipo de situação, é possível conseguir sim. Dia desses até que falei com o Marco ${ }^{261}$ sobre isso, e ele reafirmou que para usar a caxeta que tem na restinga é possível conseguir autorização com mais facilidade mesmo. Como estamos lidando com as ostras e graças a Deus o mercado se abriu para essa mercadoria, precisávamos de caixinhas para embalagem delas. Soube, mas não tenho certeza, que tem um cara que fabrica esse tipo de embalagem, e na verdade eu não sei nem se compensa nós mesmos fazê-las.

Com relação às ostras, posso afirmar que está vendendo bastante agora. Tem o lado bom disso, né? O Ricardo Magalhães se aproximou da gente para pegar amostras das nossas ostras. A gente começou a mandar de pouquinho, dez, cinco dúzias... Ele é o dono de uma empresa que se chama Guará Vermelho, de São Paulo, mas trabalham associados com o pessoal de Peruíbe, de Caraguatatuba, mas desses lugares eles negociam vieiras, não ostras. Vieira é um marisco muito com a ostra, pô! É redondo, quase igual a ostra. Mas aqui não tem. Então essa empresa de vieira, que começou no mercado comercializando apenas esse marisco, começou a expandir os negócios e as ostras se tornaram importantes para fazer a empresa crescer. Foi quando o Ricardo Magalhães fez um projeto e disponibilizou um dinheiro para essa finalidade, para que a gente conseguisse fornecer. Quando a verba acabou eles conseguiram tocar o projeto por eles mesmos. Eles ainda vieram aqui, pediram as amostras, e a gente começou a enviar.

O pessoal aqui do parque ajudou como pôde, principalmente com o transporte e com a coleta de ostras com a gente, basicamente essa foi a ajuda que tivemos. Começou

\footnotetext{
${ }^{261}$ Marco Oliveira é funcionário da Fundação Florestal.
} 
então a análise da mercadoria que enviamos como amostra, mas acho que já faz um ano que essa análise foi feita.

A gente mandava amostra para ir direto para o mercado, direto para os restaurantes. Mas antes sempre estavam fazendo análise da água, para ver se é boa ou não. Se não me engano era a fazia essa análise, e o Edson ${ }^{262}$ ajudou bastante com isso.

As análises foram feitas, mas agora as normas mudaram, tem que ser semanal, $e$ é caro para fazer toda semana.

Mas antes, era preciso obter o selo SIF ${ }^{263}$, agora não é mais obrigatório. Se você tiver o GTA, já pode comercializar. O GTA é um tipo de uma guia que autoriza o transporte de animais vivos. Mas para conseguir, é preciso passar por um veterinário, e isso é caro Na comercialização de vieiras eles não pagam direto para o veterinário, pois existe um convênio com o município de onde extraem e então eles conseguem a documentação praticamente de graça.

São dessas coisas aqui que nós precisamos aqui! Se não temos esse tipo de parceria, convênio, todo o processo vai travando... o comprador pede nota fiscal, exige documentos... A gente vende, só que os clientes vêm aqui visitar os viveiros das ostras, que ficam um pouco mais para frente da Ilha da Casca. Os viveiros são todos próximos uns dos outros. Aquele que visitamos era o viveiro de ostras do João ${ }^{264} \ldots$ O pessoal que vem são donos de redes de restaurantes, e se a gente não conseguir os documentos, eles não conseguem manter a compra, encerram o acordo. O principal documento do qual dependemos é mesmo o GTA; o segundo é o documento que atesta a análise e a qualidade da água e da ostra. Chegam a pedir até um quilo de carne de ostra por semana... eu acho que equivale a umas quinze dúzias, por baixo. Mas isso a gente consegue fornecer sem problemas. Existe perda, ou melhor, nem podemos chamar de perda, porque para quem vende as ostras por $R \$ 2,00$ a dúzia.... Se doamos quinze dúzias, para vender depois num preço bom, pode parecer que houve perda num primeiro momento, mas depois vem o ganho com as vendas, desde que a gente não perca o cliente.

\footnotetext{
${ }^{262}$ Edson Issao Sassamoto é engenheiro agrônomo e trabalha na secretaria municipal de agricultura de Cananeia.

${ }^{263}$ Selo do Serviço de Inspeção Federal (SIF)

http://www.agricultura.gov.br/comunicacao/noticias/2010/07/especial-sif-atesta-qualidade-de-produtosde-origem-animal Acesso em dezembro/2016.

${ }^{264}$ João Xavier, beneficiário da RDS Itapanhapima e também colaborador deste trabalho.
} 
Na verdade, aqui ninguém hoje tem mais esse documento, nem o Jacques ${ }^{265}$; desde que essa nova norma entrou em vigor, ninguém consegue obter, porque é muito caro. A norma, segundo o pessoal do parque falou, é de 2012, mas só entrou em vigor em 2015.

Como eu sou guarda parque, eu não consigo trabalhar, eu fico aqui para ter os contatos, e despachar as mercadorias do pessoal. Então eu ganho o meu também. Eu não consigo trabalhar lá nos viveiros, eu consigo ficar aqui, despachar mercadorias, porque é uma coisa que tem um compromisso grande, não pode ter furo. Porque se furar, o pessoal já fica cabreiro. Estou fazendo esse meio de campo para eles. Mas é difícil também, porque tem a classificação. É um mercado exigente, não é pegar qualquer mercadoria lá do mangue e mandar. O pessoal exige limpeza, não pode ter lama, tem que tirar tudo aquilo, não pode ter placa.

Agora tem outro mercado, o de peixes, também. Teve um senhor que veio aqui, esse mesmo da rede de restaurantes, querendo negociar a compra de peixes. Ele falou: “vamos pegar peixe também”. Ele gostou muito daqui, ficou apaixonado. Eu acho que o nome dele é Henri, ele é francês. Fizeram visitas, foram em um grupo de 19 pessoas fazer a negociação. Afinal, ele compra a ostra! Quer ir ao viveiro, saber se de fato existe, se é no local indicado mesmo, entender o funcionamento. Ele é o cliente, né?! Daí o interesse na visita, em conversar com o pessoal.

Contratamos duas lanchas e fomos lá. Custa caro alugar as lanchas: $R \$ 700,00$, mas eles têm dinheiro. Fizemos um passeio, ficamos no Pereirinha ${ }^{266}$, almoçamos lá, e trouxemos ostras. Os caras gostaram para caramba. Contou pra gente que a partir de 2016, 80\% da mercadoria dele precisam vir dessas áreas de conservação. Não é fácil se comunicar com eles, pois falam a língua portuguesa bem mal. Aos poucos fomos nos acostumando com essa dificuldade e as coisas foram melhorando bastante e com isso já estamos conseguindo ter sustento para duas famílias, a do João e do Joel ${ }^{267}$, que moram lá. Fiz questão de apresentar eles aos compradores, porque são pessoas que tem família para sustentar né?!

O meu pai também tem um pouco de ostra lá. Mas ele não está vendendo. Ele já tem uma renda como aposentado. Como agora é inverno, eu quero ajudá-los. Eu quero que eles vendam!

\footnotetext{
265 Jacques é um conhecido atravessador de ostras na região e que compra a produção de muitas das famílias da cidade de Cananeia.

${ }^{266}$ Praia da Ilha do Cardoso que fica próxima a Cananeia.

${ }^{267}$ Joel Xavier é irmão de João Xavier e morador da RDS Itapanhapima.
} 
Os meus irmãos estão pegando caranguejo. Eu conversei com eles e expliquei que vai abrir um mercado bom, se quiserem trabalhar com ostra com a gente.

No começo é difícil mesmo, então falei que se eles quiserem, devem fazer seus viveiros, e os interessados vão fazer as visitas. Mas eles dizem que não querem assumir esse compromisso. Quinta-feira é o dia que temos que mandar as ostras. Vende em torno de 300 dúzias no verão, mas já chegou a vender 400 dúzias por mês no ano passado, que é uma quantidade bastante grande. Eles têm interesse no caranguejo também, mas a gente não consegue fornecer, porque esse animal é mais difícil de mexer, de manusear. Morrem muitos no transporte, e não pode, eles têm que chegar vivo. Caranguejo é igual a siri: morreu, a carne dele serve só para jogar no lixo. O siri quando é capturado e morre, a carne dele já está podre e em pouco tempo já está catingando. No inverno, o caranguejo é mais forte, mas no verão é fraquinho. Capturamos, por exemplo, 100 dúzias, morrem 20, 30 dúzias na viagem, porque os caras transportam de qualquer jeito. Se colocassem num caminhão frigorífico, que tem resfriamento... mas não, levam de qualquer maneira, então morrem mesmo. O caranguejo que meus irmãos vendem vão, na grande maioria, para o [Vale do] Paraíba, para o Rio de Janeiro, tem bastante interesse nessas áreas. São levados dessa forma mesmo, com bastante perda, por $R \$ 4,00$ cada caranguejo. Paga 12 aqui uma dúzia, e vende quatro reais cada um; são atravessadores. E é preciso legalizar essa prática, para aprimorar.

Cuidar da água, aí a gente conversa na Ilha da Casca, pois lá seria um lugar bom para fazer. Tem também a questão da energia elétrica, que não tem. Como que vai colocar depuradora lá, se não tem energia? Depuradora é um tanque de água, que você coloca para nada mais do que purificar. Passa nos filtros, a ostra abre a boca, ela toma aquela água que está filtrada, e libera a água que tem resíduo nela. Não melhora nada na qualidade da ostra. Só que às vezes fica um resíduo, tem que limpar...Com energia solar, por exemplo, pode ser que ajude se for um painel potente, pode ser que funcione sim, para usar bomba de água.

No Instituto de Pesca, por exemplo, tem uns problemas... uns problemas entre eles, problemas pessoais, entendeu? Falam que é o Edson a raiz do problema, mas eu acredito que se a gente conversar com ele, a gente resolve. Tinha um projeto de fazer um píer, aproveitando o grande fluxo de pessoas que passam por ali no fim de semana, um ótimo ponto de venda, precisava ser limpo e preparado, construir um barracão para bater a ostra... Gente como o Jorge e o João por vezes batem a ostra embaixo de chuva forte! Tem gente que compra um trator de $R \$ 30$ mil, e deixa lá no parque parado, 
entendeu? $R \$ 250$ mil e deixa lá parado. Porque não usam esse dinheiro pra comunidade viver melhor, não é verdade? Como não tem dinheiro? Se tem dinheiro para investir e deixar parado no lugar? E fica lá, uma vez em três meses, o pessoal usa o trator para alguma coisa. E vale $R \$ 300$ mil! Poxa, investir $R \$ 300$ mil numa comunidade! Imagina o que não daria para fazer! Por isso que eu falo pra você, às vezes o erro vem das coisas mal planejadas. Porque se a pessoa olhar bem, porque esse cara está errando? "Ah, está errando porque esse cara começou errado!". Às vezes eu fico analisando isso. "Ah o cara trabalha de forma errada!' Bem, então nesse caso todo mundo está errado! Porque quem tem condições de ajudar, não é criativo, entendeu? Você acha que investe num patrimônio para ficar parado aqui. Sendo que tem um monte de família precisando daquilo ali. Vamos fazer o que é prioridade!

Houve, na verdade, umas oficinas que foram organizadas para instruir nesse processo. Nas que a gente pode ir, a gente foi, né? Teve oficina no Mandira, no Rio Branco, eu acho que teve até uma no sitio também, e o pessoal foi lá uma vez. Só que eu acho que quando o pessoal foi lá, participaram advogados, engenheiros... e informaram que pelas demarcações existentes que não podem ser alterados, o local de manejo não poderia ser aquele onde as oficinas ocorriam... Foi feito o levantamento relativo ao que o parque tinha tomado dos usuários, entendeu? Por exemplo, tinha área de roça, de plantio dentro do parque, ele foi fazer esse levantamento, ai ele falou que poderia ser alterado. Só que ninguém consegue alterar mais isso ai. A briga do Osmar para a mudar o limite até hoje não deu em nada. E aí começa a não compensar... E nossas demandas nunca são acatadas. O engenheiro, por exemplo, que fez a consultoria nas oficinas era lá da Casa da Floresta, que apresentou o plano de uso, mas nunca mais voltou.

Quando o parque foi feito, por exemplo, não fomos sequer consultados. Ficamos sabendo que éramos uma RDS quando um dia de manhã chegaram na minha casa avisando, os guarda parques foram lá e afirmaram que a partir daquele dia essa área virou uma reserva, e que se quiséssemos deveríamos procurar nossos direitos. Falei para meu pai que cabia a nós nos defendermos e ele não quis nem saber. Conversei com advogado, que disse que não compensava abrir processo judicial, que nós não receberíamos nada, mesmo sendo nosso direito. Sinto que fomos enganados aqui não assim pela $R D S$, porque eu falei para o Osmar "que criem então a RDS, e com a RDS criasse alguma forma de vida, de sustento." O Osmar bem que tenta, não vou falar pra você que ele é um cara ruim não, ele é um cara que tem boa vontade de ajudar, entendeu? 
Ele é a única pessoa que cedeu para o pessoal aqui, é ele. Ele se esforça. Mas o passo dele, ele é limitado, não consegue liberar nada.

Nessa época o gestor da RDS era o Wilde ${ }^{268}$, e com ele era diferente, era acostumado no Amazonas, chegou aqui e fez um projeto absurdo, sabe?! Ele falou "vamos legalizar tudo. Vamos legalizar pontos de pesca, vamos cadastrar o lugar aonde que usa, qual o nome da pessoa, me vamos fazer os barracos, refazer tudo novo". O projeto dele era isso, construir casas, banheiros que não tinha. Só que quando ele foi para o governo do Estado, e colocou essa proposta ai, ele viu que não era igual lá, porque isso lá é rápido para ele no Amazonas. O Estado lá, ele faz um projeto desse lá, os caras aceitam na hora, entendeu? E aqui fez, e ficou... O projeto era bem intencionado, propunha melhorias... mas não saiu do papel. Tipo, tem uma pesca ilegal, não é verdade? Aí tem um cara que vai e fica lá, não é de lá, ai sai fora, passa um mês volta, só para invadir uma casa vamos dizer. Ele não tem vínculo nenhum com ninguém lá. E isso não está regulamentado. Aí ao que você faz? A regulamentação facilitaria a vida da fiscalização, porque o cara chega aqui, tem 30 barracos, vamos dizer, como o cara vai identificar morador tradicional e invasor? Não tem como. Facilitaria a nossa vida também: o pessoal iria ter um cadastro, tirar tudo os pontos pelo GPS, tem um que não está no GPS, não tem ponto, esse cara invadiu aqui, entendeu?

Na ilha do Tumba, por exemplo, tem ainda bastante ponto de pesca, barracos de pescadores, mas muitos tiveram que se deslocar daquele lugar e conseguiram se estabelecer aqui, um pouco mais para baixo, pois estavam dentro do parque, que nunca existiu, por que não era parque ali, mas como é terra de ninguém o cara vai aumentando cada vez mais. Nem quando foi criado o parque, essa área não era restrita, isso aconteceu agora. Foram vendo que essa uma terra que estava perdida lá, e foram aumentando, eu acredito que foi assim...

Até o ano passado, ninguém nunca tinha se incomodado em relação ao lugar dos barracos de pesca. Porque você acha que só porque é parque, o cara demora tanto para ver assim? Eu acho que as coisas estão mudando mais ainda. Eu acho que eles enxergam como uma terra que não é de ninguém, “vamos tirar quem está aqui, para não ter vinculo nenhum”, e pronto. Pra eles tem outro lugar pra eles ficarem também, não é problema isso daí, como pro João e pro Joel, que estavam lá, no Itapanhapima, mas não era. Retiro é aonde meu pai está, o João está, e Itapanhapima é aonde está o seu Dito e meu tio

\footnotetext{
${ }^{268}$ Wilde Itaborahy foi o primeiro gestor da RDS e RESEX.
} 
Gentil, o Nildo, a família dele, o Dito, e o filho do senhor Dito, o pessoal deles lá. Umas 10 famílias no total. Ou melhor, família na verdade é uma só, porque o meu tio Gentil, o filho do Senhor Dito é casado com a filha dele, né? Tem o Pontes também, que é parente nosso, da minha avó, mas não sei se é o mesmo Pontes, mas eu acho que é sim. Dentro da RDS tem também o João, um senhor de lá também. Tem outro senhor perto da casca, tem um sitio também, não sei o nome dele, eu acho que é Tonhão.

Sobre a empresa que chegou, como minha mãe lhe contou, não foi exatamente uma compra. Havia um senhor que era morador de lá, o senhor João Alves, e a família dele, aí o pessoal fez uma proposta que ia pagar um dinheiro pra ele, que não sabe nem ler nem escrever. Ai o genro dele, passou uma procuração pra ele concordando com aquilo, sendo que o senhor nem sabe ler e escrever! Foi enganado pelo genro em conluio com o pessoal da empresa, Sulcar era o nome se não me engano. Há um processo correndo no Fórum, em nome do meu pai, do Armando, do Gentil, do Antônio Cordeiro e Antônio de Godoi, foram esses quatro posseiros que brigaram, junto com o padre João que é falecido. Foi ele que deu essa causa ai, senão ninguém ia conseguir. Esse padre João era um cara inteligente! Lembro bem dele, lutava pelo direito das pessoas, dos mais pobres. Já morreu, mas não me lembro quando. Mas era um homem importante pra nossa gente. Era um cara orientador, o pessoal ia lá, fazia festa, os caras queimando fogos. Ai meu tio uma vez encarnou, queria dar um tiro no cara. Ele chamou meu tio e falou: não faça nada, se você fizer isso, ai você vai agir sozinho, porque eu não vou agir com você mais. Então escuta o que eu estou falando, faça tudo como eu disser que vai dar certo, entendeu? Não é pela violência que vamos ganhar isso aqui. Tenha calma que eu vou ganhar, ele e aquela advogado Dr. Antônio, é ele mesmo, Dr. Antônio, mas não lembro o sobrenome dele....

O padre João falava, o juiz acatava, entendeu? O promotor também, todo mundo acatava o que ele falava. Ai ele foi orientando, senão acontecia uma tragédia mesmo, porque os caras chegavam lá atirando. Foi um momento mais difícil aquela fez. Ai nesse caminho que eu falei pra você que a gente ia pra escola, a pessoa cercou um lado e outro, ai deixou a cerca de arame, porque iam colocar búfalo, já pensou, nós iriamos passar não meio daquilo. A cerca veio e deixou um caminho só para passar. Ai o meu pai veio aqui e falou pra ele, agora fechou o cerco, porque o cara vai fechar o caminho. A hora que ele chegasse com os bichos ele fechava tudo, ai nós ia sair por onde? Ai ele falou “calma ai!”, ele foi direto e falou com o promotor. Ai deram autorização para cortar a cerca, ai todo mundo pegou alicate e foi. Tem até hoje cerca lá. Eu sei perfeitamente 
aonde tem a cerca ainda. Os caras falaram que o brejo era bom para colocar os búfalos, que o bicho tomava banho, né? Tem os brejos lá. Aí pegamos o alicate e cortamos toda a cerca em pedacinho pequeno. Aí começou a ficar feio pra eles, ele começou a entrar com a ação mais forte, mas foram oito anos de briga. E, meu pai tem lá a reintegração de posse, ele tem assinado, tivemos ganho de causa. Isso foi uma coisa que estragou mais o lugar, foi isso. Porque aquela família que era do nosso lado, eu sempre falo, o inimigo, quando está dentro da sua casa, é o pior inimigo. Depois, para poder conviver no mesmo lugar, eles pediram desculpas, quando eles viram, o genro mesmo do senhor João, o cara que vendeu, vendeu todos nós, porque ele passou pra eles que tinha uma área desabitada, ele falou isso, tem uma área desabitada que não tem morador. E os caras iam lá, e essas casas aqui? Os caras que comprou dele. Ah não, isso aqui os caras estão saindo fora já daí. E ai, ele não podia dizer para o cara que era morador, ai o padre João entrou com ação. Demorou, mas conseguiu. Antes de começar o processo judicial, teve muita briga. O Ademício, o cara que vendeu, trazia pessoas, faziam festas, eu acho que ele ganhou dinheiro... Mas o padre João também trouxe pessoas para ficar com a gente, chegaram a fazer uma cobertura lá, o pessoal tinha medo que agredissem nós lá. Porque a intenção deles era fazer alguma coisa pra pessoa sair, botar pressão. Ai faziam festas, queimavam fogos, para intimidar. Teve uma vez que pensaram em sair, ai o padre foi orientar. Não lembro direito mais, faz tempo pra caramba aquilo. Eu sei que ia um grupo de pessoas lá em casa, ficavam lá um dia dois dias, nos momentos mais difíceis, ai a gente foi superando, superando, até sair essa causa, né? Ai quando saiu essa causa, ai eles queriam ser amigos, os posseiros. Ai meu pai olhou e falou: "amigo igual você pra mim não interessa”, meu pai falou pra ele. Quando parecia resolvido esses problemas, chegou o parque. Eu falei mal do parque, mas eu fui uma das pessoas que eu aceitei isso. Porque essa empresa, a Sulcar, ela existia. E podia ser que ela entrasse com uma ação novamente, ela poderia entrar. Então se é para ter uma briga daquela que a gente teve uma vez, melhor da maneira que está. Eu estou falando pra você do passado, que era ruim, e tal, o limite do parque não é legal, porque atrapalha. Embora as pessoas não tenham mais pratica de roça, de fazer isso, e eu acho que ninguém vai ter.

O caminho da ostra é mais interessante do que da agricultura, é mais rápido, entendeu? Tem, a mercadoria é boa, a pesca, o caminho hoje é isso. E a pesca também. Eu só digo para ter o limite do parque, para as pessoas fazerem as canoas, continuar naquela atividade, que é uma coisa da cultura da pessoa, que eu acho que qualquer um tem direito. Algumas coisas foram prejudicadas, coisas da nossa cultura, nosso modo de 
vida. Eu acho que dessa maneira que está, cada um vai mudando a cultura da pessoa, porque ai a opção é construir outro tipo de embarcação, entendeu? Inventar outra arte. Porque você não vai ficar a vida inteira se deslocando, para vir conseguir uma autorização, que nunca sai, não é verdade? Você vem aqui, vai numa reunião, coloca e nunca aprova. Ai uma hora você também cansa de falar, eu acho que isso vai atrapalhar muito. Por isso que todos nós perdemos nossa cultura, as vezes por alguma coisa que está atravessando aquilo. Tipo madeira para fazer remo, está dentro do parque, cipó para fazer balaio, que coloca as outras dentro, está tudo dentro do parque. Daqui a pouco eu tenho que comprar balde de plástico para carregar as ostras. Que não tem como fazer. Porque para cortar tem que pedir autorização. Se você quer desviar da ilegalidade, pra que você vai fazer uma coisa que é ilegal na verdade. O remo também, que são as madeiras vermelhas que eles fazem, que é bom para passar a prensa que fala. Por isso que eu falo, não é falar para o cara, não faça desse aqui. O cara vai falar, "você pode fazer de outra madeira". Mas ai você já está tirando a tradição do cara, porque o cara já está acostumado a fazer daquela forma dele. Toda vida ele fez assim. Isso vai perder cada vez mais, e a pessoa com isso ele vai se deslocando entendeu? Porque é um lugar de difícil acesso. Você se depara com coisas que você não consegue resolver. Você tem que ir a reunião, e ficar batendo, ah tem que conseguir isso, aquilo.

Sabe, eu sou conselheiro ainda, mas nem todo mundo gosta disso. O costume das pessoas lá é ir no lugar e resolver a situação dele. Porque ele não tem tanto tempo para ficar correndo atrás daquilo. E quando ele pede, não é igual o cara da cidade aqui que é malandro, o pessoal de lá são simples, são honestos. Eles quando pedem alguma coisa, é porque sinceramente estão precisando daquilo, não é que estão pedindo, na malandragem. Não tem malicia, são pessoas sem malicia. Eu acho isso que vai perder cada vez mais. A canoa já não conseguem fazer mais, por esse motivo ai, por causa do parque, entendeu? Eu mesmo, quando eu saí de lá, eu já tinha três filhos. Naquela época eu não era de respeitar ninguém não. Mas eu saí de lá já faz uns cinco anos, mas nessa vida eu aprendi muita coisa. Meus irmãos não mudaram, eles são assim. Porque nós éramos juntos, aonde estava eu, estavam todos ali, risos. Porque dava certo, eles andavam comigo. Ai eu planejava, eu que terminava, eи que decidia, eu que pagava, eu era assim com eles. Tanto na época do palmito, como com a ostra, caranguejo... caranguejo eu peguei só uma beiradinha, que era muito difícil. Então eu vím pra cá, entrei na empresa para trabalhar como vigilante, antes da fundação. 
O Osmar dizia "eu vou dar força para você." Eu nem queria, entendeu? Porque até hoje eu ganho muito mais do que isso. Lógico que era uma atividade ilegal, mas tinha mês que eu andava com dez mil no bolso, entendeu? Não era só meu o dinheiro. Aí para ficar um mês esperando para eu ganhar 1500 reais, ai eu falei: não quero isso. Então de tanto insistir, mamãe falou, faça o curso, todo mundo dá uma força pra você. Todo mundo me ajudou. Eu fui, mas não fui para entrar de cabeça. Achei que era por um tempo, mas agora gosto bastante. Quero me aposentar lá! E outra, você aprende de outra forma, aprendi bastante coisas no curso, que é importante para vida da gente, né? Não é pelo dinheiro, mas pelo conhecimento, você vai conversando com as pessoas, entendeu? As pessoas que eu achava que eram meus inimigos, hoje almoçamos juntos... para mim é uma gratificação isso. Porque eu estava errado, e achava que eles eram pessoas ruins. Mas ninguém é ruim. Os caras me consideram para caramba, eles mesmos me defendem hoje. Esse é um camarada da gente, me defendem mais do que qualquer pessoa, entendeu? E eles gostam de mim, não só por falar, mas é verdade isso. Na época do palmito, teve um dia, eu fui ter um atrito com uma pessoa, igual eu tinha, entendeu? Eu estava no trabalho, o cara começou a caçar e tudo e eu falei: "pô, eu não acredito que eu vou ter que mexer com isso!'. Enquanto era só ele tudo bem, então ele começou a levar pessoas. O cara é valente, igual a mim! Eu me deparei com isso, o cara não acatava ninguém. Quando foi um dia, eu falei, vamos fazer um cerco e vamos dar um jeito nesse cara aqui. Ficam uns lá embaixo no pear, o cara não veio, sei lá se ligaram para ele. No outro dia que eu fui trabalhar, ele me chamou: chega aqui para nós conversamos. Ele falou: minha vontade é dar um soco na sua cara. Eu falei: isso não vai compensar para você. Tinha duas cadeiras lá, eu sentei na frente dele, ele nervoso, que saia água do olho até. Ele chorou de raiva. Sentei com ele, fui conversando.

Era um morador de lá. Mesma coisa que eu era, mas comigo não teve essa conversa. Eu falei: olha amigo, essa escola que você está fazendo, você está nela e eu já saí dessa escola, entendeu? Tudo isso eu já fiz e não me compensou. A única coisa que eu ganhei foi desamizade. Eu falei: você mora do lado da nossa guarita aqui, eu acredito que você não vai querer desamizade com a gente. "Ah não, para mim vocês são uma ameaça". Eu falei: "analise bem antes de você falar. Porque você falou para o gestor que eu te persigo". Porque ele falou assim, ele queria saber do nosso superintendente da empresa, qual era o nosso limite. Ele falou que a gente não tinha limite, se houver uma ocorrência a gente têm que ir lá. Aí que caiu a casa dele. Ele falou o cara está certo. Ele chegou a falar com meu supervisor, depois conversei e ele falou: "tudo bem cara, não 
vou trazer meu sogro mais", dai o cara entendeu e não trouxe mais. Mas porque eu pude controlar a situação, porque eu aprendi, se fosse em outra época eu jamais teria feito assim, entendeu? Quando eu estava do outro lado, do lado de cá, não tinha conversa. Eu cheguei a ir no parque, conversar com o diretor e disse: eu faço isso, porque é o caminho para sustentar minha família, eu não tenho opção. Agora matar um bicho, vocês têm um cartão, passam o cartão de vocês no mercado lá, pega o que vocês quiserem e vão embora. Eu a única coisa que eu tenho é o bicho na minha frente e ou eu como o bicho, ou eu morro de fome. Se vocês têm um caminho, me falem, eu não sou a pessoa ruim que vocês acham, eu só não tenho opção. Uma vez um cara, o cabeludo, queria cinquenta quilos de semente de guanandi. Eu me empenhei naquilo, dava cinquenta mil sementes, e vamos coletar, vender, porque era um caminho para eu desviar daquele palmito maldito, que azarava minha vida. Então o cara falou: é pior do que você pensa, porque tem uma portaria que cuida das florestas, é federal. Coletei um pouco, ele me pagou. Era assim: vai um dia embaixo de uma árvore e veja. Isso é pratica. Quantas sementes caem somente de um pé de guanandi? É incontável, entendeu? Quantas nascem? Por isso que eu falo, tem que ter a prática no meio. Às vezes o cara estuda, estuda, ele não tem a prática das coisas. Não nasce nem $30 \%$ da semente. Porque a semente, os animais tiram aquela polpa, o morcego, aquilo é mais fácil de germinar. E as outras que caem com a polpa não nascem. Porque não tirava de uma arvore só e você acha que vai fazer falta aonde tem 50, 100, 200, sei lá eu, é incontável as árvores que tem lá.

No plano de uso não tem coleta de semente permitida, porque não era uma prática isso, não existe isso lá, mas é um caminho. Ah não pode vender. Que fizessem uma troca com o cara, o cara tem outra coisa lá, leva guanandi e o cara da outra coisa. Mas não é assim que funciona. Mesmo a questão do guapuruvu, né? Lá aonde nascem os guapuruvu, a maioria que nasce, é aonde é roça, ela demora não sei quantos anos para germinar a semente. Ela é uma pedra pura, então ela cai, ela vai se enterrando na terra e quando o pessoal faz a roça e passa o fogo, ela estoura a semente, por causa da temperatura. Todos eles são em lugar de roça, aonde tem mais quantidade, é tudo lugar de roça. E hoje está tudo dentro do parque...

Meu tio Gentil, por exemplo falou de voltar a plantar porque ele tem um pouco de roça ainda. Ele consegue ainda plantar alguma coisa... só um pouquinho de coisa ele quer plantar. Já os filhos do Dito trabalham a maioria aqui na cidade, né? Vão para lá final de semana, às vezes pescar... a maioria trabalha com pesca. Alguns trabalham na cidade. Mas a atividade deles antes era roça. 
Eu já tinha uma casinha na cidade, porque na verdade eu tinha uma embarcação lá, eu vendi a comprei a casa. Eu tinha que vir aqui e ficar na casa de vovó, ela é velhinha, eu enchia o saco dela, porque eu era bagunceiro! Bem antes de vir para cá, a gente ficou lá um tempão.

A escola fechou há uns 12, 13 anos já. Foi bem antes dos meus filhos nascerem. Então quando eles nasceram já não tinha escola. Fechou por falta de aluno, não tinha aluno, então escola do Estado que fechou não abre mais, né? Quando meus filhos nasceram já dava para reabrir a escola! Meu irmão Nivaldo também tem duas filhas, o Eliseu não tem filhos e o Fábio tem duas, mas já são crescidas. Já estudaram... Mas não acho que a falta da escola tenha influenciado as pessoas a saírem de lá, porque o pessoal já não estava naquela animação de ficar, porque agora é diferente a situação. Até o Joel, o pessoal que estava trabalhando comigo lá, ele falou, eu vou tentar isso aqui, porque se a gente não conseguir, a gente vai sair para algum canto, alguma cidade, porque a gente não consegue se manter aqui mais. Não conseguia, é sério mesmo. Porque eles já não têm essa coragem de fazer um ato ilegal. Não sei se é coragem ou estupidez, entendeu?

O João vive de fazer pintura na cidade, quando está por aqui. E o Joel, vive só de lá mesmo, mas não vendem só para nós, vendem para outra pessoa, e só ostra mesmo. Só que eles vendem barato para o outro cara. Mas deixa o cara, que a hora que tiver faltando mercadoria ... Porque enquanto tiver suficiente para vender para nós e para ele, deixa ele. Ele já perguntou para eles várias vezes se vão continuar vendendo. Falaram que sim, mas a hora que crescer o mercado lá, não tem como. Aí aumenta o preço para eles também.

A gente antes trabalhava com palmito, mas trabalhava com ostra constante, entendeu? Porque tem o Fernando, um senhor lá e também sempre teve o Jacques ${ }^{269}$ para empresa de ostra, a gente chegava a levar 2 mil dúzias por semana. Hoje sai a mesma coisa se fosse trabalhar. Só que é um preço que não compensa nem tirar a ostra. Você vai vender a ostra, acho que é $R \$ 2,00$ a dúzia agora, mais ou menos. Para o pessoal de São Paulo, vendemos a $R \$$ 5,00 a dúzia. O preço é o que conseguimos cobrar, mas não é bom, pois sabemos que são revendidas a $R \$ 30,00$ a dúzia. Ou até mais! Uma dúzia de vieira é $R \$ 60,00$. Só que nós não temos como botar preço na nossa mercadoria, enquanto a gente não conseguir a nota disso. Na hora que a gente conseguir legalizar, a gente vai para cima da conversa, entendeu? Precisamos de uma nota de produtor, essa

\footnotetext{
${ }^{269} \mathrm{http}: / /$ revistagloborural.globo.com/Revista/Common/0,ERT148963-18283,00.html Acesso em março/2017.
} 
é importante, eu fui ver essa nota e a moça me deu os documentos que precisa para tirar, e precisa ter uma embarcação cadastrada na marinha, entendeu? Eu preciso dessa nota, eu tenho que ter um cadastro na Marinha, e eles não tem lá. E não posso fazer esse cadastro. Quem manda a aposentadoria, João, Joel, meu pai, e eles não tem documento de barco deles. É preciso ter embarcação, motor tudo com nota, certinho, mas a embarcação que eles usam é motor que não tem nem numeração mais, é tudo velho. Então agora precisa ver isso, isso, vou sentar com o Osmar, o gestor, e ver. Se o Osmar conseguisse um barco... com documentação. A RDS tem esse barco aqui, que usam para o deslocamento para trabalhar.

Se for um barco da RDS, e não pessoal, ele consegue esse documento porque se for preciso assina uma procuração, a gente faz. Eu acho que consegue sim, com empenho consegue. Ou colocar uma embarcação e documenta no seu nome, entendeu? De repente juntar todo mundo e tentar comprar... se bem que não adianta ter três embarcações $e$ não ter documento. Agora mesmo eu vou pegar uma, o Ricardo vai jogar uma embarcação na nossa mão. Vai ficar comigo, e se eu conseguisse uma autorização para deixar no Perequê ali uma quantidade de ostras, por exemplo, se alguém faz um pedido ou altera um pedido, eu não vou ter que ir lá buscar dez dúzias de ostras, botar 80 reais de gasolina para ir buscar. Eu tenho ali no Perequê que é mais perto. Mas não, não pode fazer viveiro... era só deixar uma quantidade para necessidade. E deixar guardado lá no Perequê, sem freezer, na água mesmo... Não é nem viveiro, porque não é de engorda, é só umas bolsas de tela, e coloca elas nas telas e coloca no furo, sem marcação, sem nada, depois vai com o gancho e pega. Talvez a gente consiga uma autorização provisória ele falou que vai me dar, para poder deixar lá. Mas só me deu de boca, nada por escrito, o que complica um pouco.

Daqui pra frente, pretendo trabalhar com a questão das ostras, buscar a certificação, pois com certeza é um caminho bom para o pessoal que precisa, porque o mercado lá é bom de trabalho. Que nem, cantina na beira de praia, você vende no verão, inverno você fica sem. Lá, o cardápio do cara sempre tem porção de ostras. A dificuldade é ter ostras, não ter furos, os caras não querem que fure. Para viabilizar os viveiros, a fundação doou as primeiras telas, outra a Cooperostra tinha lá na época. Uma pena que hoje não tem como trabalhar com a Cooperostra, pois na verdade ela nem existe mais. As pessoas ainda não sabem, mas não existe. Nem CNPJ ela tem, não tem mais nada! É como uma empresa fantasma. Nem os impostos ninguém consegue pagar! É tanto imposto que meu pai, e um monte de cooperado deles lá, receberam uma carta que 
deviam pra um cara lá, cada um quase $R \$ 50$ mil, e o nome dele estava no Serasa por esse motivo.

A cooperativa funcionava, mas funcionava assim, negócio que todo mundo mexe, e o cara quando vê o dinheiro, o dinheiro é a raiz de todos os males. Com o dinheiro vem uma outra intenção das pessoas, entendeu? Querer passar os outros para trás.

Pelo meи pai, o que eu vejo que aconteceu com ele é que vendia as ostras lá, e uma vez trouxeram a nota no valor de 4 mil, porque vendia bastante. É que era um negócio muito bom e trouxeram um valor de 4 mil, mas a parte dele não pagaram. $\mathrm{Na}$ verdade o papai entrou na Cooperostra para encher número, porque a Cooperostra era exclusiva do Mandira, eles não sabiam disso ai. Eu não me associei com eles, entendeu? E daí não pagaram meu pai. Aí eles ficaram com a renda, e foram vendo como ir tesourando os outros. Eu, no meu ponto de vista, vejo isso. Eles pensavam: esse cara está aqui, mas não deveriam estar. Eu fui fundador daqui, fomos nós que fizemos os primeiros esforços para fazer a cooperativa, eu e meus irmãos, então como vamos fazer para tesourar esses caras? Então vamos dando o golpe no cara que ele vai desanimar e sair fora. Ele veio com a nota para o meu pai de quatro mil, e falou, se o senhor quiser o senhor vai lá receber, em Peruíbe, Caraguatatuba, entendeu? Você falar para o papai ir para Caraguatatuba receber uma mercadoria, é você falar que ele não vai receber mais. Porque ele não vai mesmo.

Foi bom pra nós isso, porque os cooperados, na verdade, foram burros, todos eles, os cooperados e o fiscal da Cooperostra. Porque eu não vou confiar no cara, o cara não é da minha origem. Eles pegaram e colocaram o senhor Rudson, e depois o Zé Marcos um cara que já faleceu. O que o Zé Marcos fez, é que ele era vendedor, e foi conhecendo o campo, entendeu? O Zé Marcos saiu fora de lá. E montou uma empresa para ele de ostra. O cara conheceu o campo, montou uma empresa para ele, e falou: não, minha ostra é a mesma da Cooperostra, eu vou vender aí. A filha dele que toca hoje. Esse cara é para quem meu pai vende, que pega do Joel também, e não é bom para nós isso. Eu não sei o nome da empresa, mas ele morreu e ficou pra filha dele. Depois colocaram o senhor Rudson.

Esse processo que veio para eles e o senhor Rudson, deu um calote na Cooperostra, de não sei quantos mil, porque também não era um cara deles, e segundo eles o cara desviou o dinheiro da venda. Só que ninguém consegue provar. Ele entrou com ação contra os associados, que estavam acusando ele, do constrangimento que ele passou, porque ninguém tinha prova ... e não conseguiram provar mesmo. 
Eu acho que foi mal administrado, eu acho que se o gerente da cooperativa, tivesse autonomia assim: estamos vendendo a ostra a dois reais, vamos dizer, mas tem custo de energia e tal, todo mundo vai colaborar, custo é custo, combustível e tudo, mas não teve esse cara para fazer isso. Você pega um caminhão novo, dá na mão de todo mundo, os caras vão moendo, vão trocando os pneus, o dinheiro vai ficando ali, foi muita bagunça. Ai não tem como um negócio desse.

Meus pais e irmãos todos eles eram associados, mas meus irmãos não chegaram a vender, nunca venderam nada para eles. Meu pai vendeu bastante, então começaram pagando, depois começaram a enrolar, e ele foi indo e se irritou, e quis sair fora dali, mas ele chegou a ir no ministério público e não conseguiu sair. Porque o Chico que é presidente na Cooperostra falou que não podia tirar meu pai, se não tivesse outra pessoa para ficar no lugar. Você acha que é justo isso? Porque a cooperativa ela tem um total de pessoas para funcionar. Se sair um fora, não é cooperativa mais, e ele não tinha essa pessoa. Ele se desentendeu com o senhor Chico, papai deixou de ir lá e ficou assim, nem o promotor conseguiu dar jeito, talvez ele seja associado ainda. E tinha muitas ONGS que ajudavam eles, dava $R \$ 200,300$ mil tinha caminhão novo, tinha caminhões, tinha tudo para funcionar. Falta de ajuda não foi. Eles estavam preparados para trabalhar. Uma pena! Tinha tudo para dar certo.

Eu acho que de imediato, queremos fazer uma associação, porque tem que facilitar várias coisas. A gente quer abrir um box de mercado municipal, entendeu? Não vamos pagar, o Ricardo falou que paga, para a gente fazer a limpeza da ostra, para gente vender lá mesmo. E a depuradora ele dá para a gente fazer o nosso trabalho, ele é um cara legal nessa parte ai. Você já consegue, por exemplo, eu posso pedir uma carta, eu já falei para o Osmar fazer uma carta, para pedir um box lá, talvez de uma forma que não precisa pagar, tudo aquilo é para a comunidade. E até pensar num espaço que pudesse vender o produto das duas... porque não é meu, é nosso, é das pessoas que pegam mercadoria para vender, eles vão lá vender, eu não vou ficar lá, só que eu quero uma pessoa honesta lá, para o dia que for prestar conta, se o cara deixou lá, eu vou exigir isso. Associação não é muito difícil. O problema da associação, que é o medo de todos nós, eu também não quero ser, é o presidente, né? Porque sempre sobra para o presidente. O cara fez uma associação de veludo aqui em Cananeia aqui e depois ela devia mais de 15 mil. Sobrou para o cara a divida, porque gera juros isso. Isso que é o problema. Uma coisa que é de todos, eu vou assumir, ou outro cara vai assumir? 
Talvez seja essa a diferença de associação pra cooperativa, porque pela cooperativa talvez possa colocar no nome de todos cooperados.

Uma coisa que pega também, como eu já falei, não investem nas unidades ... lá não tem embarcação para socorro, não passa médico, isso é direito humano. Ter uma embarcação de socorro no lugar, ou passar e pelo menos perguntar, você está vivo aí? Lá, nós não estamos incluídos nos direitos humanos. Eu mesmo, a cobra me picou lá e meu primo que me socorreu. Não fui embora porque ela não tinha veneno suficiente, porque se não, em duas horas eu tinha morrido. Eu levei duas horas para chegar aqui. Cheguei de barco toque toque, eu com minha perna dessa grossura, e a dor, e eu cheguei a aguentar aquilo. Cheguei e o médico falou: se tivesse que ter matado você, tinha matado já. Quando ele me deu aquela injeção que são duas ampolas, eu senti um calor no rosto, no pescoço, veio descendo, e ele falou: agora dependendo você pode morrer, se você sentir um sufocamento na garganta, um aperto você me fala. E ele ficou com olho em mim assim.

Médico por exemplo nunca passa por lá. É um lugar de difícil acesso, pergunta para quem sabe, maré mês tal vai baixar, tem tudo isso. Mas eu acho que não tem desculpa não. A vida da pessoa é um patrimônio sem valor né? Osmar colocou uma antena lá, isso para nós hoje é mais importante, a saúde, um médico, uma antena pra comunicação, porque se o cara pedir socorro, eu não vou medir esforço, para ir, eu não vou pedir licença e nem falar para ninguém, não vai dar tempo de dizer. Agora se não tem comunicação, não consegue fazer isso. O Osmar colocou uma antena lá, ela pega, mas as vezes não pega. A altura é pouca, tem que ter uma altura melhor.

E agora para o nosso comércio, tem que ter comunicação entre nós. O cara tem que ficar aqui na quarta feira tal hora, tem que pegar o pedido tal hora para trazer, num minuto eu posso ligar para o cara, e falar, traz tanto de tal tamanho. E acho que se conseguir a ilha da casca para fazer os barracos, o pessoal limpar as ostras, não precisa deslocar até a casa do cara, para não trabalhar na chuva, entendeu? Eu acho que o Brasil está numa situação difícil, mas eu não acho que é impossível isso aí. Precisaria fazer um barracão, depois uns quiosques, minha ideia era essa. O cara tem ostra boa, o turista para, compra, vende direto, melhora a renda da cara lá. Mais para frente até abrir umas ostras lá, entendeu?

Não queremos a ilha para nós, é o uso dela, para melhorar as condições, porque o acesso ali que é fácil. Os viveiros eu falei para o Osmar que tinha que ser ali. Porque longe o cara vai e furta as ostras. Ali vai ser difícil do cara furtar. No meu tio, do meu 
pai também teve furto ... a maré seca, o cara vai. Eu falei: “João, vamos ver isso. Acho que sempre tem uma pessoa lá, do Instituto de Pesca, no final de semana também." Se tem a pessoa lá, ela já fiscalizaria os viveiros. O cara já estava ali e podia revezar com outro. Até eu ficaria lá. É gostoso ficar lá um dia.

Tem jeito de melhorar as coisas, tem muito jeito. Isso não vai gastar um milhão de reais, é só pegar o dinheiro e vir direto. A maior dificuldade é isso, porque achamos o mercado e ele não vai parar.. Mas temos que dar os pulos, uma maneira de conseguir trabalhar. Porque você iniciar uma coisa, daqui a pouco o cara pede nota, a origem do dinheiro, a associação tem que ter uma conta, porque eu não vou ficar depositando dinheiro na minha conta. Eu tenho que ir em Registro e sacar o dinheiro para pagar os caras, minha conta é lá. Eu não vou ficar abrindo conta em todos bancos.

A associação poderia ter uma conta, porque é um peso também para eu sair. $O$ primeiro passo é formar essa associação, mas muito deles não tem carteira de pesca. Eu falei para eles: "vocês vivem disso." Falaram que vão fazer. Nem o Joel tem a carteira, mas a esposa dele tem! Já o João não tem... e é fácil de fazer! Pega uma testemunha, isso é fácil, ninguém vai recusar isso. Tem que ver isso, quem toparia entrar, e quem não. $O$ Adilson, que é gente boa também, já foi da cooperativa e também saiu fora, ele era associado lá também. Mas a associação seria dos moradores da RDS, não teria nada a ver com Cooperostra. Eu posso perguntar, conversar com eles, mas ai vem associação, já vem o presidente... Se não tiver mesmo como não ter a figura do presidente, precisaríamos pensar em fazer um outro documento, em que ele não se comprometa sozinho e todo mundo assinar, como se fosse um presidente de fachada. Porque hoje está no vapor, amanhã pode ser que não seja, ai a hora que o barco figura, todo mundo quer pular pra um lado. E não é justo... E não da coragem de ninguém assumir a bronca. Não é que eu sou negativo, mas é pensando em possibilidades de coisas que podem ocorrer. Prevenção, né?! Porque sobra mesmo, e eu conheço vários presidentes que estão ferrados. Porque fica devendo, e vai aumentando, vira uma bola de neve.

Lembro do meu pai, vindo para cá... Ele produzia as coisas no sítio e vinha na cidade vender banana essas coisas... ele fazia isso, e vinha remando toda vida. Mas era legal até. Mas para vir para tudo, médico, tudo, era no remo! Mas isso faz tempo também. Depois eu tinha bastante embarcação. Porque hoje a gente é bem fechado mas é importante a gente conversar e dialogar com os outros, você consegue abrir caminho para as coisas. Porque se eu fico lá, eu vou conversar com o macaco, o macaco não sabe responder.... Então, quando eu saí, isso foi bom. Se eu fosse conversar com você antes, 
eu não conseguia conversar, eu ficava tremendo, nervoso, hoje eu fico nervoso um pouquinho, mas é normal. Às vezes o pessoal da USP vinha colocar as placas solares lá, eu não conseguia conversar, ficava nervoso, entendeu? Meus primos são tímidos, eles fogem da presença dos outros ainda. Não é maldade, eles não têm costume disso, é tipo índio. Então para mim foi bom quando vim para cidade, eu consigo conversar com os outros, entendo mais coisas que eu nem sabia, hoje eu sei. Eu estava estudando também, mas eu saí, não consegui esse ano, o segundo do Ensino Médio, muita correria, eu estava me matando, até pressão alta eu tive! Porque eu venho de lá sete horas, vou lá em casa, ai chego onze horas, e eu trabalho muito. Tem vezes de ficar três dias sem ir em casa... Porque eu faço esses corres da ostra, e faço a entrega lá em casa mesmo, aqui em Cananeia, na rua Piauí e o pessoal vai pegar lá. O João e o Joel trazem para mim, a gente vai buscar no portinho que fica perto de casa, mais ou menos $1 \mathrm{Km}$ de distância.

\subsection{O caminho das ostras}

Adelmo é filho de Armando e Dirce, e um dos mais jovens dentre os nossos colaboradores. Sua narrativa apresenta muitos dos aspectos citados anteriormente pelos outros colaboradores em relação às características da vida rural na região, como o deslocamento para a cidade e a dificuldade em obter renda e bens de consumo. Entretanto, diferentemente dos colaboradores mais velhos, que narram um passado de fartura, suas lembranças da infância são permeadas pela dificuldade do pai em criar dez filhos e a

rotina de trabalho estabelecida desde cedo. É o único que apresenta claramente a problemática da extração ilegal de palmito na região. Ele aponta o fato de que sempre soube tratar-se de uma atividade ilegal. Entretanto, reconhece a prática como parte de uma cultura local amplamente disseminada entre as populações rurais. Além disso, justifica a extração de palmito pela escassez de recursos e pela necessidade de sobrevivência em áreas com poucas ofertas de trabalho, e cuja renda gerada pelas roças é considerada insuficiente.

Para ele, a roça não constitui uma opção de vida, na medida em que exige muito tempo de dedicação e cujo retorno financeiro não contempla suas expectativas. Narrando as dificuldades da vida dos palmiteiros, ele destaca as privações dos acampamentos na 
floresta e principalmente a repressão dos guarda-parques que combatiam a extração ilegal de palmito: "Eram os nossos piores inimigos", nas palavras de Adelmo.

Ao refletir sobre a questão da imposição de leis e a atuação repressiva dos agentes do Estado, ele analisa que sua forma de pensar era decorrente de uma sensação de injustiça em função da transformação de seu território em área de conservação sem que nenhuma contrapartida fosse oferecida. Mesmo se mostrando atualmente mais compreensivo, suas críticas são similares à dos demais beneficiários: a criação da RDS Itapanhapima foi realizada de forma arbitrária e sem consulta aos afetados. Além disso, ele não concorda com o teor de algumas leis, sobretudo no que diz respeito à impossibilidade de retirar madeira para a produção de canoas. Para ele, "tudo foi muito mal estudado" e o resultado sempre foi desfavorável para as populações locais. Destaca também a necessidade de revisar os limites territoriais da reserva, a fim de permitir que as áreas de plantio sejam respeitadas. Mesmo não tendo intenção de trabalhar com a roça, acha que a medida é necessária para outras famílias. É importante destacar que a crítica de Adelmo se dá no mesmo sentido que a de Gentil: o problema não está apenas na forma autoritária como a RDS foi construída, mas também na inexistência de alternativas de trabalho e produção que pudessem substituir as atividades tradicionais que foram abandonadas forçosamente pelas famílias. Segundo Adelmo:

Quando o parque foi feito, por exemplo, não fomos sequer consultados. Ficamos sabendo que éramos uma RDS quando um dia de manhã chegaram na minha casa avisando, os guarda parques foram lá e afirmaram que a partir daquele dia essa área virou uma reserva, e que se quiséssemos deveríamos procurar nossos direitos. Falei para meu pai que cabia a nós nos defendermos e ele não quis nem saber. Conversei com advogado, que disse que não compensava abrir processo judicial, que nós não receberíamos nada, mesmo sendo nosso direito. Sinto que fomos enganados aqui não assim pela RDS, porque eu falei para o Osmar "que criem então a RDS, e com a RDS criasse alguma forma de vida, de sustento." O Osmar bem que tenta, não vou falar pra você que ele é um cara ruim não, ele é um cara que tem boa vontade de ajudar, entendeu? Ele é a única pessoa que cedeu para o pessoal aqui, é ele. Ele se esforça. Mas o passo dele, ele é limitado, não consegue liberar nada.

Apesar da manutenção das críticas, Adelmo, atualmente, busca construir caminhos para adaptar-se às normas e restrições impostas pela RDS. Segundo ele, a ostra é uma atividade viável porque já está prevista pelo plano de uso e por isso eles não 
precisam contar com a morosa emissão de licenças realizada pela Fundação Florestal. Graças a sua vivência na cidade, ele voltou a estudar e participa ativamente das discussões no órgão gestor. Também é guarda-parque do Parque Estadual, o que lhe permitiu entrar em contato com as leis ambientais restritivas e com o outro lado da história, já que ele atua como agente do Estado e portanto, como o repressor que tanto criticava. Com as informações obtidas a partir dessa nova experiência de vida, passou a conhecer os procedimentos que envolvem a comercialização direta da ostra. Assim como os demais produtores, a existência do atravessador (como a empresa Jacostra) é identificada por ele como um dos fatores que impedem a valorização do trabalho de coleta das ostras. Em parceria com outros beneficiários, como seu cunhado João Xavier ${ }^{270}$ e o irmão deste, Joel Xavier, pretendem formar uma associação e obter as licenças e autorizações necessárias à comercialização do produto. Vale ressaltar que os viveiros de ostras foram construídos graças a um projeto, talvez o único, implementado pela Fundação Florestal como resposta ao plano de uso. As telas para a construção dos viveiros foram fornecidas, e os beneficiários interessados passaram a realizar a engorda das ostras em locais específicos. Esta é uma experiência considerada positiva pelos beneficiários e que pode ser melhorada. Para Adelmo, o próximo passo é a criação de uma associação que possa organizar os produtores e obter conjuntamente as autorizações e estrutura necessárias para a venda da mercadoria. Para tanto, ele reconhece necessitar da Fundação Florestal. A instituição já realizou parceria parecida com a Cooperostra (Cooperativa dos Produtores de Ostras de Cananéia), trabalho que chegou a ser premiado pela "Conferência Rio+10, das Nações Unidas, em Johannesburgo (África do Sul), como uma das 27 melhores iniciativas no mundo de desenvolvimento sustentável e combate à pobreza". ${ }^{271}$ Infelizmente, trata-se de uma experiência que hoje não existe mais. Assim como outras iniciativas na região que não funcionaram, essa experiência acabou gerando uma visão negativa do trabalho associativo, e romper com ela também é um desafio. Apesar de não ter tido continuidade, a Cooperostra tornou-se um exemplo para Adelmo de que parcerias são possíveis, e que a Fundação Florestal pode ser um facilitador para o desenvolvimento de projetos voltados para as comunidades beneficiárias das unidades de conservação.

\footnotetext{
${ }^{270}$ João Xavier colaborou com muitas informações dessa pesquisa. Conheci sua área de trabalho e os viveiros de ostras, mas infelizmente não conseguimos formalizar a entrevista.

${ }^{271} \mathrm{http}: / / \mathrm{www} 1$. folha.uol.com.br/fsp/dinheiro/fi2110200329.htm Acesso em dezembro/2016.
} 


\section{Dona Tuca - Bertolina Penache.}

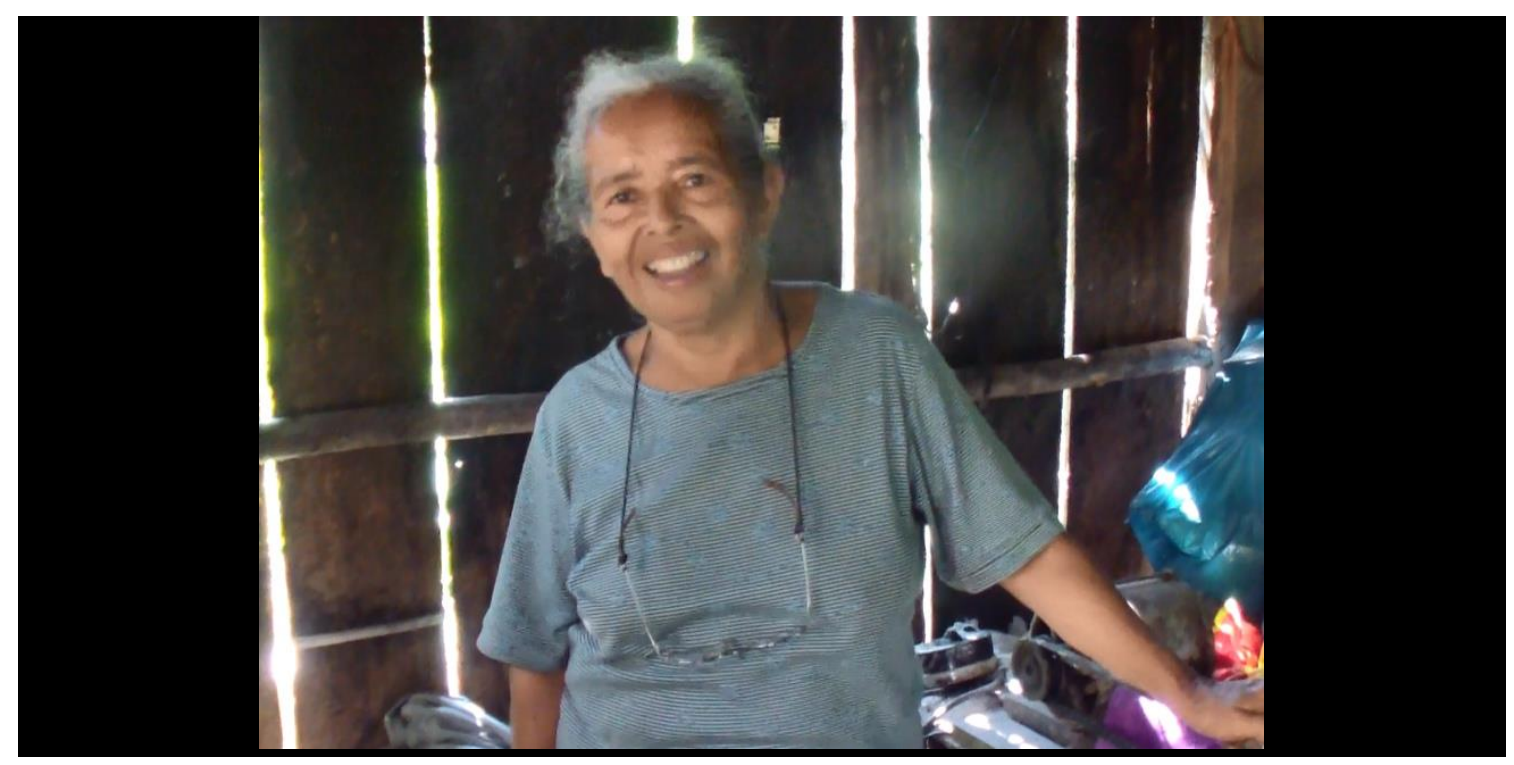

Dona Tuca é bastante conhecida na cidade de Cananeia, sobretudo por seus produtos de ótima qualidade, como a farinha. Moradora do bairro Santa Maria, ela é uma referência, uma espécie de avó de todos. Parteira e profunda conhecedora de muitos medicamentos tradicionais, ela continua a realizar pequenas roças no sítio, onde vive com seu marido Júlio e um dos filhos mais novos. Apesar de inicialmente pouco receptiva à ideia de gravar uma entrevista, sua recepção foi encantadora. Além de conhecer o seu rico quintal, pude provar seus bijus e o café que ela mesma planta.

\section{“Quem sempre conservou e ainda conserva essas terras somos nós! Nós não temos culpa do} que acontece lá fora, que eles acabam, destroem a terra e ficam sem nada.”

Tuca

Sou nascida em Santa Maria, criada desde criancinha e moro aqui até hoje. Só que hoje estou muito triste porque a gente morava com os pais da gente e se criava, né? E hoje, não. Hoje as mães vivem no bairro sozinhas. Com essa história do verde, de reflorestar e não deixar plantar, não deixa roçar e não deixar queimar, os meninos crescem e vão ficar fazendo o que aqui? Acabam indo para a cidade trabalhar... Só ficam 
os casais de velhos sofrendo por aqui, e isso me deixa muito triste. Eu me criei na casa dos meus pais, e a gente vivia só da lavoura, da caça ... Inclusive, a gente nem ia pra Cananeia, as compras que a gente fazia era no máximo umas duas vezes por ano. E a gente comprava num ano e só pagava no outro! Só no outro ano que ia pagar!

A gente comprava de tudo, tudo o que precisávamos, em Cananeia: roupa, calçado, carne seca... O meu pai comprava a carne seca em fardos grandes, não era um quilo e nem dois não... inclusive, a gente comprava lá naquela venda de Polo Paiva em Cananeia, que muita gente nem conheceu. Mas eu conheci! Ficava ali perto da CEAGESP. Íamos de canoa, remando, com a canoa cheia de arroz, de milho, de porco... Daí chegava lá, vendia tudo, pagava as contas pendentes e comprávamos tudo de novo, para pagar dali um ano. Hoje, se você comprar três meses, já não consegue pagar mais. E não tem quem forneça isso também. Lá, a gente ia comprar roupa, comprava pano de peça... Inclusive, os meus pais compravam muitas peças de pano só para fazer roupas das meninas, e outras peças de pano só para fazer roupas para os meninos. Era tudo igual. Sapato, nem era sapato na verdade, era um tipo de tamanco, e também aqueles tênis Conga. Os tamancos eram que nem esses que hoje estão moda, que tem só um courinho na frente onde enfiava o pé e pronto! Era o calçado que iria durar o ano todo!

A gente se criou em muitos, muitos irmãos. Éramos em seis da primeira família do meu pai, do primeiro casamento dele. A mulher dele faleceu, ele casou de novo com minha mãe e tiveram mais sete filhos, e eu era a mais velha entre esses sete.

E minha mãe criou todos os irmãos: os seis do primeiro casamento do meu pai e os sete que eles tiveram. Éramos em 13 irmãos! Mas isso não era um problema, a gente se criou com muita fartura. Todo mundo ajudava na roça, eu ajudava desde pequena.

Tinham também os mutirões para roçar e depois para colher. O mutirão era assim: todo mundo se juntava para trabalhar, alguns ficavam preparando a comida, fazia o almoço, a janta e de noite todo mundo se divertia no forró, né?! E todo mundo ia, todo mundo se ajudava, pra comer, dançar, dar risadas... e assim o serviço rendia muito.

Eu mesma não cheguei a participar desses mutirões não, mas os meus pais sim, fizeram muitos. E assim a gente se criou, desse jeito. Meu pai ia para o mato, matava dois ou três porcos-do-mato. E como a gente não tinha geladeira né, como agora temos geladeira e freezer, aí salgava a carne e colocava em cima do fogo para secar e colocar num cesto grande. A gente ia comendo no dia a dia, pegando de pedaço, cozinhava, fritava e até tomava com café. A mistura da gente não era pão e nem era essas coisas, era carne mesmo. Tirava os pedaços de carne, e como já estava seco, ia lá, macetava 
bem macetado e comia com farinha. A gente também fazia paçoca de carne de porco que meu pai caçava e secava. A gente tinha muita fartura de comida.

Naquele tempo o costume era cozinhar o feijão e o arroz junto. Não tinha essa história de cozinhar o arroz separado. A carne também, quando ela estava fresca, eles faziam aquele tique-tique, né? Cortava as carnes tudo em pedacinho, cozia e depois colocava o arroz junto, cozinhava todos os ingredientes juntos, juntava até o feijão, e sem panela de pressão. Era só a panela de ferro direto no fogo. E não demorava tanto, pois naquele tempo, comíamos o feijão da lavoura, que era bem molinho e novo, né?

Tinha tanta coisa... era tão bom aquele tempo... Meu pai trazia milho verde para gente naquele cesto grande que é usado para colocar no cavalo e carregar todo tipo de coisa. Então ele trazia toda aquela cestada cheia para gente comer. E não faltava nada, tinha de tudo. Era pouco, é verdade mas tinha e dava para todo mundo comer. Hoje em dia é tudo diferente. Agora quase ninguém sabe passar a mão numa enxada nem lidar com a lavoura.

Hoje em dia, os jovens não sabem trabalhar mesmo, não mexem com lavoura, plantação, colheita. Eles ficam o tempo todo na escola, e quando saem de lá eles já vão trabalhar fora. Aí ninguém aprende a trabalhar na roça... Mas o meu filho não, ele ficou até os 18 anos e só depois saiu para ir para Cananeia. Atualmente mora em Curitiba. Morou em Cananeia um tempo, depois foi fazer a vida em Curitiba. Minha filha também ficou comigo até os 18 anos, depois casou e foi morar em Cananeia, até hoje. Tem muita gente nossa, gente daqui, que foi morar em Cananeia, especialmente os mais moços. Isso acontece muito mesmo, por causa disso que estou falando. Não tem serviço aqui. E os meninos querem comprar as coisas, as meninas querem comprar, né? Por isso acabam mudando, por que aqui é tudo difícil para eles. Aqui tem que trabalhar na lavoura, e na lavoura não pode mais trabalhar como antigamente. E serviço de empregado não tem por aqui, né? Aqui não tem fazendeiro, por exemplo, que pega um monte de gente para trabalhar. Então aqui só ficam mesmo os aposentados, os mais velhos. Alguns conseguem emprego como caseiro, mas são muito poucos...

Bom, pra mim até que a vida é boa, né, porque sou aposentada e aífica mais fácil. Mas para o pessoal não é bom não. Amarrar esse mato e cortar palmito, é muito longe! A madeira, que tem bastante, não podemos mais tirar. Nem areia não pode mais tirar. Porque nós somos ricos em madeira e areia, mas aqui a gente não pode fazer disso uma forma de trabalho, para conseguir o sustento sem precisar se mudar para as cidades. As coisas mudaram muito de uns anos para cá, com certeza. Principalmente quando não 
tivemos mais licença para trabalhar, não pode nem mais fazer a queima. Não pode roçar, não pode derrubar e não pode queimar, então vai plantar o quê? Embaixo do mato só dá palmito juçara, café, banana branca, mas outra coisa não dá. Arroz, feijão e milho, isso não dá na goteira, não dá embaixo do mato.

As coisas mudaram muito mesmo principalmente quando não conseguimos mais essas licenças para fazer a roça e tudo o mais que é preciso para produzir na terra. Por muito tempo conseguimos fazer a roça, a queima e não dava problemas. Hoje, se você faz uma roça e queima, dizem que os guardas descobrem, pois acham por cima.

Fomos sim avisados sobre ofim das licenças para fazer nossa roça, numa reunião que muita gente queria participar para conseguir a licença e poder assim mexer com a terra. Eu mesma fui a primeira que fui lá e consegui a licença, mas agora não tem mais como. Como que a gente vai ficar sem poder plantar nada? Com um mundo de terra aí, a nossa terra dá de tudo, só produto bom, de qualidade. E temos que comer essas comidas que vem envenenadas de outros lugares. O pessoal da cidade só come porque precisa, não tem outro jeito. Eles não tem onde plantar na cidade, mas nós temos! E nós não vamos também acabar com a nossa terra, porque a terra é nossa e precisamos dela. Quem sempre conservou e ainda conserva essas terras somos nós! Nós não temos culpa do que acontece lá fora, que eles acabam, destroem a terra e ficam sem nada. Se outros não cuidaram né, nós cuidamos! Você acha que vamos estragar uma coisa que é da gente? Então, se eles viessem aqui e liberassem ao menos um pedaço pra gente poder trabalhar nele... depois passava um tempo, liberavam outro pedaço... e a gente ia vivendo do que a terra produz. Mas não, não tem como produzir mais. É que nem a pupunha, agora a novidade é plantar pupunha. Mas a pupunha não dá embaixo do mato, tem que cultivar num lugar aberto. Tem que roçar, derrubar e queimar tudo o que precisa, e não pode mais. Pro arroz, feijão, milho... tudo precisa queimar. Vai colocar esses entulhos aonde? Não tem como sem queimar.

Não tem uma ajuda do governo para fazer nada. Porque trabalhar com a terra crua é difícil demais, demorado. E durante esse tempo, o que a pessoa come? Eu faço porque eu mantenho esse pedacinho, e a gente é aposentado e pode pagar os camaradas para ir ajudar a carpir, mas e quem não pode? Aí não faz! Até os jovens estariam trabalhando. Eagora? Onde eles ficaram, piorou muito. Porque é na área da reserva e não podem fazer nada. 
Foi numa reunião que a gente foi com o agrônomo Sassamoto que soubemos que a partir daquele momento não poderia haver mais queimada, e então começou a ficar impossivel viver da roça.

A minha mãe era do Paraná, meu pai era daqui mesmo, era descendente de portugueses e minha mãe era descendente de índios. Muitos me chamam aqui de baiana, mas eu não sou da Bahia, sou descendente de índios e de portugueses, tudo aqui da região. Eles se conheceram porque ela veio com a família do Paraná morar aqui. E aí deu certo deles se juntarem e formarem sua família. De todos os filhos, só sobraram duas irmãs e eu. Os outros já se foram, e essas duas moram em Cananeia. Tem uma que trabalha na prefeitura, e a outra trabalha lá no mercado Takagi. Elas se criaram aqui e depois foram embora. E nesse tempo, o meu pai morreu, mas eu já era casada, e morava aqui mesmo.

Meu pai e minha mãe me ensinaram a lidar com a roça desde que era menina. A minha mãe era muito trabalhadeira, o meu pai era muito trabalhador e poupava muito, tudo que era possível. Inclusive, eu aprendi muito com ele, que falava assim: "vocês não estraguem as coisas, porque estragar não é fartura”. E não é mesmo! Todo mundo trabalhava na roça. E sempre desde bem cedo. Eu comecei a lidar na roça com 7 anos de idade. Eu tratava a roça, e já ia plantar o meu pedacinho. Meu pai sempre fazia a gente ir para roça plantar um pedacinho pra gente, a gente tinha o pouquinho da gente, a gente tinha a galinha da gente, cada um tinha a sua galinha e seu pato para ter cuidado. E a gente tinha que cuidar! No período da tarde, todo mundo ia pegar o seu e ia aprender, e deu certo! Todos aprenderam bem dessa maneira. Era até divertido! Às vezes tinha uns que eram mais descuidados, deixavam o pintinho solto e ele morria na chuva. Tinham outros mais cuidados, que ganhavam elogios. E a gente quer ser elogiado pelo pai e pela mãe, não é?!

Era um bom jeito de aprender. E de incentivar também as crianças a trabalharem e se responsabilizarem. Porque nesse tempo não tinha escola mesmo; no tempo da gente não tinha escola. Cheguei a ir à escola, mas estudei só por seis meses, depois abandonei.

A escola já era lá onde é agora, mas era uma escolinha de madeira e ficava muito longe de onde a gente morava, não dava para frequentar não... Morávamos na colônia Santa Maria, que era muito longe da escola. Daria uns dois ou três quilômetros embaixo do mato. Não tinha estrada, era caminho matado. E todo dia era no meio daquela lama. Foram meus pais mesmo que me tiraram da escola, por que era muito sacrifício. E naquele tempo podia tudo. Hoje não pode tirar da escola. Eu tinha muita vontade de 
estudar, mas era muito difícil seguir estudando. Quase todo mundo desistia. Até tentava, ia por um tempo, aprendia a fazer o nome e então desistiam. Era o que bastava, bastava assinar o nome e já estava bom. Aí vinha para a roça trabalhar.

Aprendi a fazer de tudo em casa com minha mãe. Farinha, torrar café, ir pra roça, fazer biju, cuscuz. A gente faz um cuscuz de arroz e fica soltinho. Pila o arroz e coloca de molho. Aí deixa escorrer, vai socar e vai peneirar. Aí depois coloca na cuscuzeira para fazer o cuscuz. Vira uma massa de arroz. É como faz do milho também. Você rala, põe de molho, solta e faz uma massa para o cuscuz. A gente fazia farinha de mandioca, farinha d'água...Era só colocar a mandioca de molho, deixar ela curtir até amolecer. Ela fica com aquele cheiro forte. Coloca então na prensa, voa e faz farinha. É uma farinha grossa. Essa dá para comer com comida. E a farinha d'água é mais para comer com café, com leite... A única diferença é que para fazer uma tem que deixar a mandioca de molho e para fazer a outra não precisa. Você traz a mandioca da roça, raspa e prepara. É fresquinha! Eu tenho até a massa para fazer a farinha dela. Está no freezer.

O café, depois de colhido, fica secando, e depois coloca no sol para ficar bem pururuquinha. Aí pila o café e depois vai para a torra. Soca numa máquina e vai peneirando até ficar parecido com esse aí. A mão de obra do café é bem grande. E a fumaça quando está torrando o café é muito forte. E a fumaça da farinha também. A farinha, além da fumaça, tem o calor do forno que é preciso encostar. Inclusive, quando forno está bem quente, eu costumo fornear com o rodo para não queimar a pele: coloca um rodo de cabo comprido e vai mexendo de longe. $O$ cheiro da farinha é bom, mas o cheiro do café é forte demais.

Para fazer o açúcar é preciso moera cana, coar bem num pano e colocar para ferver. E depois que ferve vai tirando toda aquela espuma preta e deixa só o caldo limpinho. Deixa apurar até chegar no ponto de açúcar mascavo. Faço açúcar, rapadura... Temos muita cana plantada aqui. E fazemos tudo aqui. Nós não comprávamos o café, a gente moía o café, torrava... De tarde era a vez da cana. Era comum fazer o café de garapa, misturando café com caldo de cana para beber um café mais gostoso. Eu nunca gostei muito. Mas as minhas crianças gostam. Todo fim de ano que eles vêm, tomam café com garapa. Você toma um copo de café e já sente o peso. Enche! É como um café bem pesado. E tem muitas visitas que chegam de Cananeia, que gostam de tomar café com garapa! 
Eu já pensei uma vez em morar em Cananeia sim, mas o Júlio ${ }^{272}$ não quis ir. E agora resolvi que só vou sair daqui no dia que não der para eu plantar mais nada, que eu não conseguir mais. Pensei em ir viver lá por que só tenho uma filha e era muito agarrada com os netos. Por isso pensei, mas depois ele não quis ir e não quis deixar. E por causa da cheia também, que aqui é muito alta... A cheia vai lá naquela marca daquela parede lá, e isso é complicado de lidar, mas não é todo ano. Demora. De seis em seis anos dá essa cheia. Daí tem que levantar tudo para cima e é um sacrifício danado. Já perdi minhas coisas por causa das cheias. Por isso que olha o tamanho da geladeira! Ela é pequenininha, e na hora da cheia a gente pega e coloca em cima da mesa para não estragar. Mas faz parte da vida... tudo é vida! Eu criei os meus três filhos aqui, e eles aprenderam todos a nadar. E eu mesma não sei nadar, nunca quis aprender, nunca fui de nadar. Meus filhos aprenderam com os camaradas daqui mesmo. A minha filha nada muito bem. O meu filho também, a minha neta também, o meu neto que mora em Curitiba também... Com a cheia aqui na porta, eles atravessam e vão embora. Eles gostam!

Uma vez, a cheia levou a ponte. Para sair daqui, tinha que fazer um caminho longo para chegar lá perto do Carlinhos. Caminho mesmo, não tem, né? Só que aqui, como é tudo limpo, a gente só faz uma picada e vai! E daí conseguimos nos deslocar durante esses períodos de cheia.

Eu já trabalhei muitos anos em feira. Foi junto com o pessoal daqui. E, eu acho que trabalhei uns dois anos sozinha, quando os demais não tinham o que levar e eu me mantive sozinha por dois anos, três talvez.

Eu carregava os produtos em um caminhão, fazia as coisas todas para levar na sexta feira. Dormia lá, e sábado trabalhava na feira. Tinha um caminhão pra isso. Depois fiquei ruim da perna, parei e entrou outro prefeito que tirou o caminhão e acabou a festa! Parei de levar as coisas, mas fiz as minhas freguesias, né? E falei: "olha, eu parei com a feira, mas na hora que vocês quiserem podem encomendar." Ontem mesmo, o meu genro ligou para encomendar vinte reais de biju. Não tem dia marcado não. Na hora que der, eu levo. E vendo café por encomenda, vendo biju... Até o mês passado eu vendia arroz. Agora acabou. Vendo inhame, cará... Só que agora não está na época de cará e inhame. Vendo abacaxi, geleia... de goiaba, de abacaxi, doce de carambola, geleia de carambola... Tudo de compota.

\footnotetext{
${ }^{272}$ Marido de Dona Tuca
} 
E farinha também. Mas eu parei de fazer, estou fazendo mais é biju. Porque fui fazer a conta, e não dá para ganhar nada. E a gente tem que vender algo que dá para ganhar alguma coisa. Eu vendo a oito reais o quilo da farinha, e é barato, muito barato. E é ruim de fazer farinha. E é muito quente, né? Deixo mais para fazer no frio.

Feijão eu planto pouco. O feijão era pra estar maduro em outubro, mas esse ano choveu muito e eu perdi todo o cultivo, mas era bem pouquinho. Milho também não vendo não. Eu até cultivo na roça, mas é só para comer, guardar, fazer polenta, bolo... No freezer tem bastante. Ovos, quando eu criava galinha, eu vendia. Agora não dá, porque o milho está muito caro. O milho está mais de $R \$ 50,00$ o saco. E não daria para cultivar em grande quantidade, o pasto que tenho é muito pequeno para plantar milho suficiente. A gente já criou porco, mas parou de criar por causa da cheia. Com a cheia, tudo tem que ser muito alto e a criação acaba perdida nessas épocas de cheia. Por causa disso que as casas aqui são todas altas, por conta das cheias mesmo. Ela começa encher de manhã, e quando é uma hora, duas horas, já está baixando. Mas fica a trabalheira. Muito barro, tem que jogar água e passar o rodo. Só que, a agua morta quando ela vem, ela não dá prejuízo. Porque tem lugar que leva a casa embora, né? E aqui, não. Ela só cresce e depois vai embora. Só é ruim porque ela tira muito os adubos da planta. E, eu costumo colocar muitas palhas da lavoura que a gente colhe, daí ela vem e leva.

Como adubo coloco também cinza do fogão. Eu aprendi a fazer a cinza com a casca do ovo! Eu sou muito curiosa! Outro dia a Viviam veio aqui, e ela é agrônoma. Saí com ela, a gente foi ver as plantas e ver o que estava precisando. A Viviam é uma que trabalha só com mulher. Que trabalha na DAP ${ }^{273}$, que pode fazer aquele empréstimo com carência. Ela vem só no barracão para fazer o negócio para o pessoal. Mas nesse dia ela veio trazer umas folhas da DAP que faltavam, e ela veio aqui em casa. É um direito que a gente tem, que está tudo escondidinho. Porque, no caso, as mulheres que mantêm as coisas em casa e o marido que planta. Mas ela também trabalha. Então agora nós temos direitos, e os nossos direitos estavam escondidos. E agora tem ela para mostrar que nós mulheres temos direito. Acho que ela trabalha para o estado. Todas as mulheres, vai tudo lá para o barracão fazer a reunião. Todas as vezes. Ela liga e já deixa marcado o dia que vem. Ai, a gente aqui, um comunica para o outro. "Olha, tal dia a Viviam vem." É aqui que ela faz, aqui no Mandira e no Ariri. É muito importante esse trabalho dela,

${ }^{273}$ A Declaração de Aptidão ao Pronaf (DAP) é um documento que identifica o produtor familiar e necessário para que esse agricultor possa participar das políticas públicas para a agricultura familiar, como financiamento da habitação rural e Programa de Aquisição de Alimentos do governo. 
muito mesmo. Porque mulher é sempre a parte mais fraca. Nem todas, mas tem umas que ainda são. E isso não podia ter né, porque o direito da mulher é o mesmo do homem. Só que tem homem que não aceita.

Graças a Deus eu vivo bem com meu marido. Aqui os dois mandam! Já temos 52 anos de casamento. A gente se conheceu aqui mesmo, porque ele era do bairro vizinho. Só tem uma diferença de idade. Ele tem 81 anos em julho vai fazer 82, e eu tenho 68 anos. Quando casamos, eu tinha 18, e ele tinha 32 eu acho. Ficou esperando! Tinha 16 anos quando comecei a trabalhar. E com 18 anos casei. $O$ casamento foi bem simples, porque naquele tempo não tinha essa coisa de festa. Eram só para os padrinhos e pronto. E a gente casou só no cartório mesmo, sem Igreja.

Antes eu era católica, e meu marido também. Agora sou da Assembleia de Madureira, e ele continua católico. Mas ele é católico daqueles que só vão na igreja quando são pequenininhos! Tem bastante evangélico por aqui hoje em dia. A minha mãe era evangélica também. No tempo da minha mãe era muito pouca gente evangélica. E ela não praticava por causa do meu pai, que era católico, e mulher naquele tempo não tinha voz ativa. Então, ela não ia na igreja. E a igreja dela não era aqui, era quase em Cananeia, muito longe, e o meu pai não aceitava. Daí depois, como ele morreu bem antes dela, ela começou a ir mais pra igreja e acabou mudando pra Cananeia. Mas ela sempre contava sobre os versículos da Bíblia pra gente, ela contava as histórias de Pedro, de João, de Tomé, de todos! Mas isso era quando o meu pai não estava em casa, pois ele não gostava. Antigamente os homens eram muito mais machistas. Ainda são! Mas um pouco menos, eu acho. Como ele não gostava, ela preferia não aborrecer ele. Mas quando ele saia de casa, ela contava para gente. Meu pai era bem machista sim.

A gente só podia sair se tivesse a permissão dele. Ela não podia decidir nada. Ela tinha vontade, mas não mandava, só ele. Quando saíamos, só podia ir para os vizinhos. Quando ele saia e ela sabia que ele não ia chegar tão rápido, aí ela deixava a gente ir brincar com as outras meninas. O negócio era ficar em casa e trabalhar, e não ficar andando pra casa dos outros, era o que ele pensava. E que eu não acho certo, porque criança tem mais é que brincar. Os meus filhos, eu criei diferente, do meu jeito. E deu certo: eles faziam as coisas, trabalhavam, mas na hora de sair para brincar, era para brincar mesmo, com os amigos, com as amiguinhas, podia trazer os amiguinhos em casa para dormir... Um dia ela ia dormir lá com as amigas dela, e faziam troca, né?! Um sempre ajudou o outro. Às vezes tinha um sentado lá no rio olhando, falando: "ó, cuidado! Saia daí porque o rio está cheio, e você pode morrer!" 
A maioria aqui tem algum parentesco. O Antunes ali em baixo, o Raymundo e a esposa dele.... O Raymundo é de Goiás, pensa numa pessoa boa?! Eu tenho muitos parentes aqui: primo, muitos sobrinhos, muitos netos... Você viu aquela moça que estava aqui? Ela não é nada minha, mas em chama de vó. Acho que é porque eu sou a parteira. Eu tinha muita facilidade de ser parteira porque a minha avó era parteira, a minha mãe era parteira, e aí acho que aprendi. E fui só eu da minha geração que virei parteira. E com 20 anos já comecei a fazer parto. E aí fui fazendo. Toda essa criançada grande aí, e com filho, fui eu que fiz parto deles. Nem tenho a conta de quantos partos eu fiz. Ser parteira é muito bom. É muito bom você ajudar a colocar um ser no mundo! Os partos sempre eram feitos de noite, de madrugada, porque filho só nasce na hora que é feito! E é difícil fazer filho de dia! É isso mesmo! Filho só nasce na hora que é feito: de madrugada, na boca da noite, de manhã cedo...

Eu fiz estudo, eu fiz seis meses lá no CEDAVALl ${ }^{274}$, em Registro. É um acampamento que vem muita gente para fazer estudo. Era com um padre. E fiquei uns seis meses lá, estudando. Como eu já era parteira e sem ter curso de nada, daí fui para lá. Teve reunião, me chamou, e fui. E foi melhor, porque tinha todos os preparos para fazer. Mas a gente ouve na barriga da mãe, e dá para sentir onde que está a cabeça, onde que estão os pés. Você vai apalpando, tem bastante movimento que facilita o parto.

As mães daqui, elas andam muito. Elas lavavam muita roupa agachada, sobe morro, anda a cavalo... O padre João Trinta que nos levou para o curso. Ele era um padre muito bom na cidade, ele era uma pessoa que ajudava muito. Inclusive, aqui na terra que vinha os grileiros de terra, ele ajudava muito.

Os fazendeiros que chegaram aí queriam pegar o terreno dos Paulas e era um terreno muito grande. Ele entrou em ação, e o cara perdeu. Fica onde você está aqui, até lá na última casa embaixo do mato.

O Júlio mesmo, meu marido, é um Paula. Você viu uma casinha de dois andares ali? Ali é dos Paulas também. É de vários irmãos. O grileiro não chegou com documento, ele achou que a área dele batia até ali, e queria cortar. Só que foi levado para justiça, e ele perdeu. O padre João sabia muitas leis. Então ele ia lá, procurava e reivindicava as leis, e a gente ia atrás! Mas nem foi nós que corremos, foi o outro pessoal lá de baixo que fizeram. E ele perdeu. E o cara era advogado e mesmo assim perdeu! .

\footnotetext{
${ }^{274}$ Centro de Desenvolvimento Agrícola do Vale do Ribeira que fica em Pariquera-Açu.
} 
Todo mês ele vinha. Inclusive, tem a igreja dele. A igreja é perto do postinho ali, para baixo da casa de dois andares. Porque a Santa Maria mesmo, ela é bem mais para frente. A Santa Maria ficou ali na casa da padroeira, que ele trouxe. Ele trouxe a padroeira e a Santa Maria. Era Taquari. Só Taquari. Foi o padre João mesmo! E quase todos os alemães eram católicos. E Santa Maria é longe daqui, dá uns sete ou oito quilômetros para chegar lá. Quando vi, eles já estavam aí, já tinha bastantes alemães aqui. Eu nasci em 1 de janeiro de 1948, e quando cheguei eles já estavam aqui. Já faz muitos anos.

Meus conhecimentos de parteira eu não transmiti a ninguém não, porque ninguém quis aprender. Na verdade, só alguns homens que viram, né? Porque eu fazia questão que o pai assistisse o parto, achava que era tão legal eles assistirem, e só dois pais quiseram acompanhar e não quiseram aprender. Teve dois, o Henri Camargo e o Francisco. Assistiram o parto da primeira filha. O pessoal tem muito aquele tabu né, aquela vergonha. E o pessoal não pode ter, não podemos ter vergonha das coisas que são tão bonitas!

Nunca aconteceu de haver complicação em nenhum parto. Graças a Deus, nunca! Só teve uma que morreu no parto por causa do marido, né? Ele deixou ela falecer. Ela estava grávida, e ele deixou ela ia apanhar lenha, e era longe. Ela foi levar comida na roça, e trouxe um feixe de lenha, e quando ela chegou numa ponte, ela cain com a barriga assim, e o feixe foi parar nas costas. E ela estava perto de ganhar, e ele deixou ela em casa muitos dias. E não avisou que ela tinha caído. Ele só veio em cima da hora. Veio aqui para eu ver que ela não estava boa. Mas teve muita gente que viu ela cair. Ele deixou e aconteceu. Ela teve descolamento de placenta, e na hora que eu cheguei, ela estava se esvaindo... Deu hemorragia e não deu tempo. E não tinha carro e não tinha nada para levar, e ele também não quis levar não. E sei que ela acabou falecendo. A criança já estava morta, já fazia uns doze dias que estava morta. Bem triste mesmo. Mas agora não fazem mais. Agora eles vão para Cananéia, e já vão bem antes. Só que tem aqueles partos de risco que não dá tempo, aí tenho que ir e fazer. Agora faz tempo que não tenho feito. $O$ último que eu fiz, eu acho que a menina está com 9 anos. A gente começou a levar a mãe, porque não estava bem. Mas não deu tempo de chegar, e a gente fez na sala do postinho. Não deu nem tempo de entrar pra dentro e colocar na maca, a sala que fechou e fiz o parto dela. E ela segurou até no carro. Eu fiz tudo. E tinha uma enfermeira lá, que ficou muito assustada. Aí fiz, e de lá, ela foi embora para Cananeia. Mas já estava tudo bem, e no outro dia ela já estava em casa. 
O mau de sete dias é que antes, eles colocavam muita coisa no umbigo da criança... antigamente eles colocavam teia de aranha queimada, pano queimado e um monte de coisa. E não precisa fazer nada disso para cicatrizar rápido. Aquilo ali vai sair. Amarrou, lavou bem com água e sábado, não precisa fazer mais nada.

Não tem mais essa história não. Há muitos anos não tem mais esse mau de sete dias. E não lavava também, ficava com medo. E é uma coisa que tem que ser lavado, passado um pouquinho de álcool e secado muito bem sequinho o local. Tem que cortar uma média de três dedinhos. E amarra primeiro para depois cortar. Mas o parto, eu gosto muito de fazer. Eu gosto, mas na hora que a criança nasce, é um ser morto. Antes do Espírito Santo entrar nele. Você pega ele ali, e ele não chora. Aí você dá um tapinha na bunda dele, e ele dá aquele respiro, daí chora. É muito bom. É a gente que tem que tranquilizar a mãe. "Não é nada. Daqui a pouco você ganha!”. Tem que verificar a dilatação né, se está aumentando ou não. Até na hora de ganhar. Tem que ser pelo menos uns treze dedos de dilatação. No hospital é tudo cesárea. Eu ficava à disposição. E fazia muita simpatia. Tinha que pegar a cinta do marido e amarrar pela cintura dela. E funciona sim! A simpatia era: no tempo frio vocêfazia um banho de assento de erva bem quente. Eu fazia muito desse pé de galinha, mentrasto... uma erva que tem aqui no quintal. Na hora que não sai a placenta, tem que fazer simpatia também. A simpatia, você procura a bolinha da placenta e faz a massagem. Você vê ali e vai apertando só com uma mão,e na outra mão vai vendo. E a placenta quando não sai, tem que assoprar dentro de um litro. Dizem que a simpatia é um litro branco, mas afinal não é simpatia, é fazer esforço, Aí é na hora que desce. Eu já sabia bastante. Eaprendi mais as coisas técnicas de hoje. Porque, eu fazia parto sem nada, sem luva e sem nada. Mas, Deus me iluminou que tenho essa saúde até hoje, né? Hoje ninguém mais faz, e nem é preciso fazer, né? Mas eu fazia sem nada. Esterilizar já tinha que fazer mesmo. Eu já deixava uma chaleira com uma agua lá no fogo, colocava a tesoura e tirava com um garfinho e deixava ela esterilizada sem pegar nela.

Eu acho que, o que eu mais gostei foi do filho do Carlinhos. Foi um parto que marcou a minha vida. Porque ele nasceu com uma renda. Ele nasceu limpinho, ele não pegou um sangue da mãe. E depois que ele nasceu, que eu fui rasgar aquela renda para tirar ele. E limpinho. Eu não sei que significado tem. Mostrei para a mãe: olha como nasceu o seu filho, com uma renda, encapado. Protegido. Era o quarto filho dela. Pena que nesse tempo não existia pelo menos um celular para tirar uma foto. Mas esse parto me marcou. Foi o mais bonito. Foi uma coisa diferente que fiquei sem entender até hoje. 
Porque todas as crianças nascem borradinhas. Nasce sempre borrada. É que vem de lá do meio da sujeira. E esse foi engraçado. Pergunta um dia para ela, pra você ver.

O meu parto foi a minha avó que fez. E dos meus filhos foi a minha mãe, tudo minha mãe. O da minha filha foi no hospital. Ela já estava pra Cananeia. Foi no hospital. Mas a natureza é muito esperta, a natureza pode ficar grande, mas ela pode diminuir também. É como eles fazem para operar que você vê que eles não operam, é amarrado. E pelo tempo, desata. Eu já vi bastante caso que desatou e a mulher engravidou de volta. Em Cananéia tem muitos casos. A natureza é muito esperta.

Aqui é para fazer uma lenha. A lenha eu fazia uma vez por ano, quando eu podia plantar e podia derrubar. Hoje não faço mais. Eu tirava toda aquela lenha e colocava dentro do barraco e ia queimando o ano inteiro. Hoje, não. Hoje tenho que ir pegando uns galhinhos aqui, outros galhinhos ali... Eu acho que tenho o direito de cortar a madeira para fazer uma lenha em casa, para fazer uma cerca. Eu vou correr atrás disso, para reformar casa, fazer galinheiro...

Eu tenho que mandar o pessoal cerrar, mas aqui eles têm medo de cerrar, alguém vir e ferrar com eles. Tem que pedir autorização. Tem que pedir lá no florestal. Eu nem sei aonde, eu ainda vou ver aonde é que vou pedir. Nem sei direito. Não frequento muito as reuniões. Muito pouco, porque eles não têm vindo aqui. Eles têm feito a reunião, mas é lá no Itapitangui. Eu não fui na que teve aqui. Eu acho que não estava aqui. Quando estou aqui, eu vou. Aquele ali são os óleos de fritura que não pode comer, eu deixo ali e guardo para virar sabão. Vira sabão. Esse aqui é o sabão. É, do óleo de fritura. Esse eu faço só para o uso. Tenho uma panela de ferro, que é de pressão. Não tem borracha, mas coloca a agua aqui para segurar a pressão. Faz um tempinho. Comprei em Cananeia. Paguei 120 reais nessa panela. Aqui é meu pó de café da lavoura. Aqui tudo é café. Aqui não se estraga nada. Isso aqui é uma mesa de uma porta de geladeira. Aquele fiz ofogão, do casco. Esses aqui é tudo vidro que faço compotas. Eu faço conserva também. Eu faço conserva de batatinha, de cenoura, de chuchu...Vai sal, loro, orégano e vinagre ou limão.

Isso aqui é um negócio para guardar mercadoria de comida, eu faço tudo aqui. Hoje mesmo vou fazer uma geleia de abacaxi. Daqui mesmo. Vai só o abacaxi e açúcar. E coloca no fogo, na panela para apurar. Às vezes a gente faz um para deixar porque aparece sempre alguém para comprar. O abacaxi fica tudo na plantação.

Aqui são as minhas plantas, que não fico sem planta, né? Aquilo ali é mexerica. Aqui é jabuticaba que sempre tem. Também dá geleia. Aqui é minha hortinha Aqui é meu 
lixo que ainda tem que queimar... eu queimo só uma coisinha. Muito pouco. Aproveito a cinza para colocar no pé da planta.

Na horta tem cebola, loro, manjericão, pimenta, inhame, milho, pimenta cumbari que é nativa do mato... Pimenta cumbari. Ela é boa para fazer remédio. Ela é boa para enxaqueca. Também dá para fazer conserva. Tem muda de limão branco, que também fica dentro da horta, tem pé de café, tem coco para cima. E quando os netos vêm, é só tomar a água. Tem água e tem carne, já nele. Aqui é um pé de café. Porque ele nasceu por acaso, e eu não quis cortar ele. E agora tem que colher ele para depois tirar. Está atrapalhando a jabuticaba. Ali tem um pé de banana ouro com um enorme de um cacho. Aqui são minhas pimentinhas doce, ela não é ardida, ela é doce. Porque não arde, é um pimentão. Você pode comer com comida. É bonitinha a pimenta, né?

Aqui é um galinheiro. O galinheiro é alto por causa da cheia. Esse aqui é lima, esse é um pé de lima. Ali é cereja. Não, é lima mesmo. A lima não tem muito doce. Aqui é tudo mato. Aqui é a floresta, e para lá tem as plantas grandes. Ali tem manga... Isso aqui é um pé de caqui, que já está com fruta. Esse caqui é gostoso. Tem banana, café, pé de laranja... Para lá é só café. Arroz é para outro lado. Milho agora não tem, mas ele fica para lá. Ali é bonito, ó. É gostoso. Isso aqui é um pé de cará amarelo. E o arraço dele vai pra cima, mas o tronco dele é em baixo. E o cará que a gente planta e que fica lá no mato. É bem amarelinho a fruta dele.

Tenho manga, jaca, conde... Tem bastante conde pra lá. Para cá é só café. Vamos ver os troncos do café. É muito louco. Daqui pra lá são os cafés mais pequenos. Eu me divirto com essas coisas. Pena que não tenho espaço para fazer mais. Esses estão aqui. Os cafés pequenos estão pra cá. Esse aqui é conde também. É a mesma planta. É uma vez por ano. Esse é pé de café velho. Agora não está colhendo. Ele tem uns três a quatro anos produzindo. Vai embora. Para lá tem os cafés pequenos. Sempre tem os pés de banana no meio, sabe? Aí tenho uma portinha de abertura, e a gente planta um pé de qualquer coisa. Esse aqui já é café do pequeno, mas só que já estão grandes também. Olha o tamanho do pau! Aí o florestal acha que só nós que vamos consumir café. E se a terra é nossa, nós cuidamos, não é verdade? Se fosse para destruir, nós já tínhamos destruído tudo.

Os policiais nunca pediram para ver. Ali é palmito no meio. Só que embaixo de um mato desses, não dá para plantar nada. Não dá para plantar arroz, não dá para plantar milho, não dá para plantar feijão, porque não dá na goteira. É só café, as 
bananas... Aqui dá para plantar os pés de banana, mas daqui a pouco já dá uns galhos que acaba com tudo também. Olha o tamanho do pau. Olha a Jussara cheia de frutas. Esse é a Jussara. Esse é o que está em extinção. Mas eu cato tudo os matos daqui, porque os passarinhos vêm, carrega e leva tudo para o vizinho. Tenho pupunha. O de lá, um dia a gente tira para comer. A gente planta só para não deixar mato, porque para vender a gente sabe que não pode. Mas para comer, a gente corta. Esses cachos que sai dele. De vez em quando meus netos vêm, tira as cascas para eles comerem, que está molinha. Mas a maioria fica tudo para o passarinho comer. O governo não deixa as pessoas derrubarem e nem plantarem, e os passarinhos estão passando fome. Eles dizem que estão cuidando da natureza, mas não estão cuidando nada! Quem cuida é a gente. Tem muito passarinho que precisa das frutas e do que a gente planta. Precisa de banana, precisa de arroz, precisa do milho... Tinha muito o Ubaitaba aqui, mas acabou a comida e eles foram embora, porque é isso que eles comem.

O tié que come arroz... São os passarinhos miúdos que comem arroz. E como só ficou umas roças para plantar, eles vêm e comem tudo. E eles acham que estão ajudando o bichinho. Não estão nada, estão é acabando. O café eles comem também. É cheio de passarinho. É tucano, sabiá e tudo quando é tipo de passarinho. Esse aqui é um pé de jambo vermelho bem rosa. Aqui estava cheio de fruta, e o passarinho comeu tudo e não deixou nada.

Eles não deixam madurar, eles comem. Então, eu acho que quem cuida dos passarinhos e dos bichos sou eu mesmo. Aqui é abacaxi. Tem bastante. A maioria eu já cortei tudo. E ainda tirei um saco lá para minha filha. Mas apodreceu bastante, porque fiquei doente e não tinha quem tirar o abacaxi. Conde é o que não falta. Isso aqui são os passarinhos que comem. Esse aqui é um o pé de carambola. Esse quando é o tempo, ele fica cheio. Está cheio de frutinha pra cá, ó.

Isso aqui dá uma geleia gostosa, dá um doce muito bonito, que é um doce tudo cheio de estrelinha. Aquele ali é um pé de lichia, tem dois pés de lichia. Aqui é o pé de mexerica.

Ali tem abelha africana. Tem essa caixa e mais aquela ali que está chegando para cá. É a bravinha. De uma caixa sai uns vinte quilos. Já era pra eu ter tirado, e eu não tirei. Ela está com pouco. Mas dá para tirar duas vezes por ano. Não dá trabalho, mas tem que ter coragem. Tem que estar com a roupinha. Eu tenho a roupinha, eu e meu marido. Tem que ter muito cuidado para tirar. 
Coloca tudo no vidro e vende. Só deixa um pouco para usar, e o resto vende. Pego e levo lá para a casa da minha filha, e deixo lá. Aviso para todo mundo que deixei na casa da minha filha, e todo mundo vai lá comprar.

Tem também as pupunhas que é para lá, tem a roça de mandioca, tem arroz... Isso aqui é um pé de limão branco. Aqui, já vou tirando as mudas e vou plantando o abacaxi. Ele demora, ele leva mais de ano para dar. Os abacaxis aqui, não tem espinho. Pode lixar a mão neles. Agora nesses aqui não dá para fazer. Olha o cacho grosso. Aqui tem um mais bonito. Isso aqui chama-se pratinha. Olha que fresquinho, olha que gostoso. Não é bom viver dentro da natureza? Por isso que a gente dentro do sitio tem muita vida. E o governo quer que a gente vá para cidade para morrer mais rápido. Chega lá para comer coisa envenenada que a gente não precisa! Aqui se faz de tudo. Aqui só não pode fazer o sal, mas o resto... Eles tinham que mudar essa lei, né? Só que a lei não é mudada.

O que mais atrapalha na lei é que o governo com tanta terra que tem, que podia trazer muita gente para colocar para trabalhar, não. E até a gente pobre que tem terra, gente não pode fazer nada, então é isso que atrapalha. Eles querem que a gente viva do que? Vai lá para a cidade, vai esse monte de gente, e vai fazer o quê? Vai virar tudo bandido e ladrão? E não dá para sobreviver numa cidade pequenininha que nem Cananeia, não tem serviço. E numa cidade grande a gente nem pode ir porque não tem estudo, não tem como arrumar serviço. Hoje para arrumar serviço tem que ter escolaridade. Por isso que vira essa bandidagem.

Muita gente foi embora, e está indo. Cada vez está saindo mais. Inclusive, o meu neto que tem 23 anos, ele está lá pra Paranaguá trabalhando. Ele diz assim: ah, se eu pudesse trabalhar no sítio, eu ia investir na pupunha. Mas como não dá para investir, tem que sair. E eles gostam daqui, eles foram criados aqui em casa.

Eu não tenho assim base, porque eu planto um pouquinho aqui, um pouquinho ali... Mas, eu precisava de mais área para poder plantar. Mas eu não falo por mim, eu falo pelos outros! Porque eu sou aposentada, mas e quem não é? Isso aqui da de tudo. Olha essas toras de banana. Aqui dá de tudo. Tem água, e se deixar madurar fica com carne! Bonito. Foi a primeira fruta que vingou. Ele só morria, morria... Isso é madeira fraca, é madeira que vai apodrecer aí. E coloco bastante cinza. Lembra queima. Olha o café madurando, já está na época. Esse aqui é uma goiaba araça que dá um iogurte muito gostoso que se faz com leite. Inclusive, eu acho que ainda tenho uma fruta lá na geladeira, que já madurou. Isso aqui, eu consegui muda lá em Paranaguá. Eu consigo muda assim, bem de longe. Olha que linda. Ela fica até arcada porque não aguenta o peso da fruta. 
Você viu que sombra gostosa? Isso é inhame. Tem muito inhame na roça. Esse aqui é meu buraco de colocar as coisas da cozinha. Tenho que tirar daqui para pôr nas plantas. Eu não perco uma casca de banana, vai tudo para a composteira. Agora vou tirar, que já está na hora de tirar, e vou colocar o outro.

Tudo vem direto da cozinha para cá. Ali é um buraco de colocar lata. Mas antes de colocar ali, eu furo ela. Aqui não tem nenhuma coleta. Porque, eu sei fazer, mas tem muita gente que não sabe. Deixa eu tirar uma lata para você ver. É tudo furadinha. E mesmo que ela encha de água, não vai transbordar. Aqui não tem plástico, é só orgânico. De três em três meses, de dois em dois meses tem que mexer, tirar. Tira e coloca outro. Vai tudo para as plantas aquele pózinho. Esse aí é um pé de banana da terra, aquela maranhão, sabe? É de fritar. Isso aqui é o burro, de prensar e secar a massa. Massa de mandioca, de fazer farinha. Aqui vai a massa, aqui prensa o tipiti... E aqui coloca as pedras para ela apertar. Esse aqui é o tipiti de secar a massa para fazer a farinha, e esse aqui é a prensa. Coloca a massa no tipiti e coloca o capacete. Aí coloca aqui, e depois coloca os calços e tudo, arria esse ganho e carrega de pedra. Aí fica uma hora, duas horas e já está enxuta a massa, e é só fornear.

O forno é lá em casa, é lá no rancho. Para mim isso aí é muito importante porque foi onde eu fiz a farinha para criar os meus filhos, e como até hoje. Eu faço para comer, para vender de vez em quando... eu não fico sem farinha. É mais para comer mesmo, não é para vender. Eu mando pra minha filha em Cananeia, para a minha neta...

Remédio agora só tenho o boldo para estômago. Amargo que só ele. Isso aqui é para dor de barriga, dor de estômago. Olha as minhas mudas. Isso aqui é tudo muda de limão branco. Só estou esperando uma chuva para levar eles para as pessoas plantarem. Está tudo no saquinho. Ele tem um galhadinho aqui, bem bonitinho.

Aqui é o rancho da farinha. Aqui no forno fica a massa e mexe... É aquela massa que sai daquele tipiti lá. E depois que ela está muito quente, eu ponho ela aqui para não pegar fumaça. Esse aqui é uma moenda de moer cana. Com motor. Só que hoje está meio estragado, queimou o filtro e não tem jeito de fazer. Aqui é a roda de ralar a mandioca para fazer a farinha. É elétrica também, porque quando a gente está cansada, aí é mais fácil. Antes era tudo na mão. Esses são todos café. Tem um que está com dois anos, outro com três anos... Aqui também tudo é café. E aqui é o ninho de galinhas em cima do café, que elas querem botar é aqui! 


\section{O quintal de Dona Tuca}

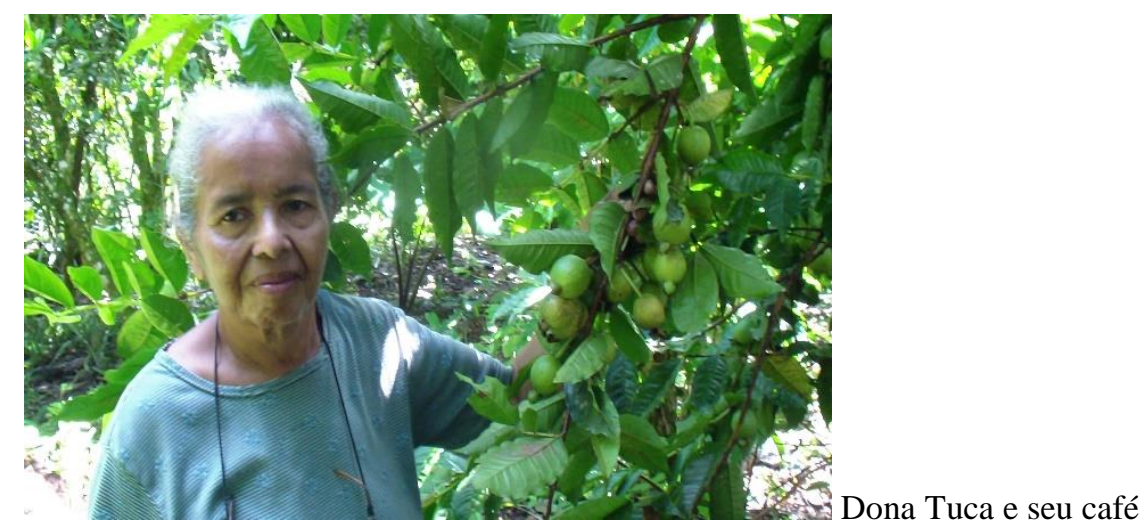

Pequena apicultura de abelhas africanas
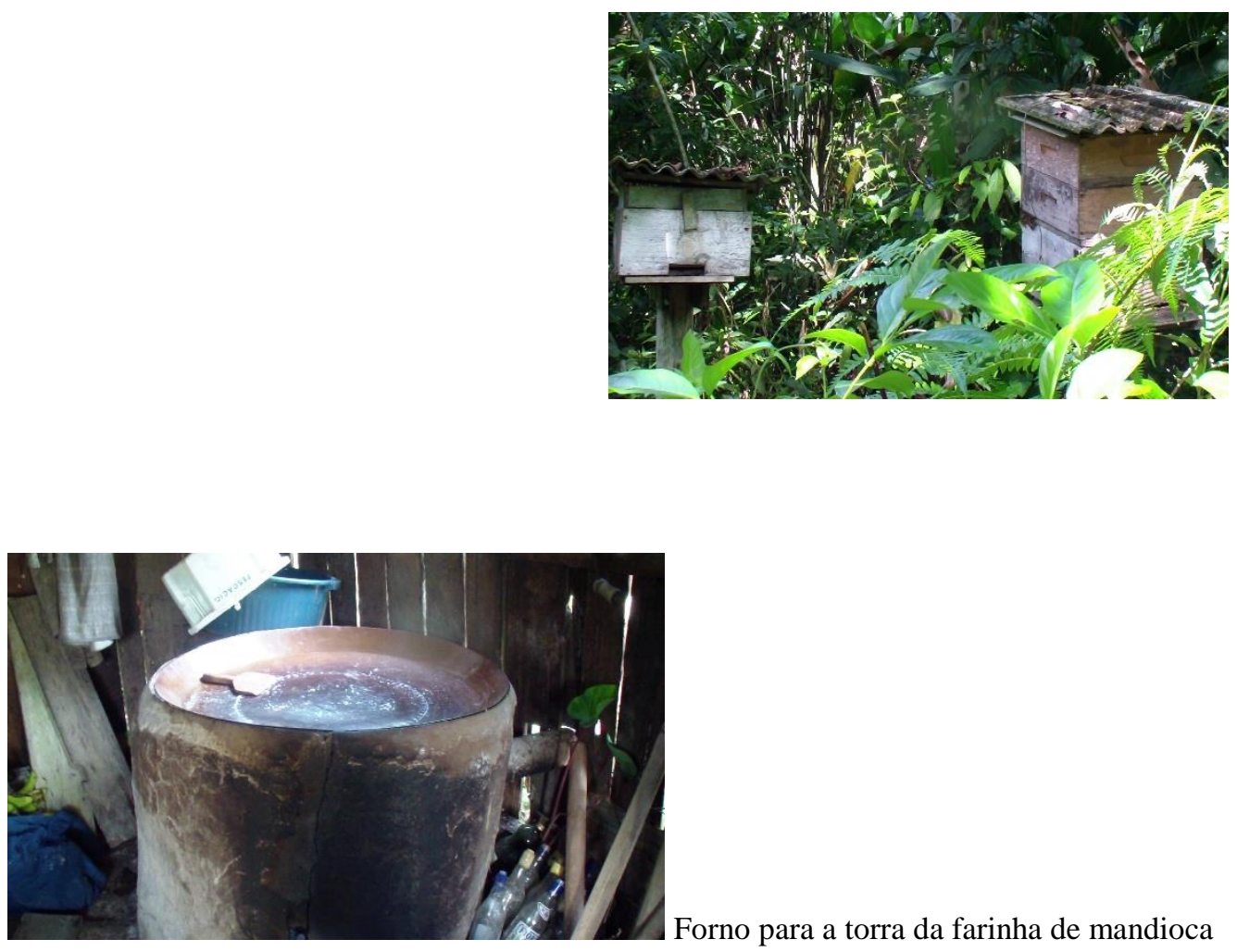

Fotos: Cássia Milena Nunes Oliveira 


\subsection{A RESEX Taquari e a agricultura: Antigos caminhos para novos caminhos.}

A narrativa de Dona Tuca apresenta muitas questões já apresentadas pelos demais colaboradores. Também para ela, a questão do direito de plantar é fundamental para viabilizar a vida de todos que moram no bairro. Em consonância com as demais narrativas, sua infância foi marcada pelo trabalho na roça ao lado dos pais, com quem aprendeu técnicas de cultivo e de manejo dos demais recursos naturais da área. No entanto, ela não vê sua criação de forma idealizada e afirma que, com seus filhos, ela buscou ser menos dura, já que o direito de brincar é fundamental. Assim como Noêmia, ela critica o machismo do pai e as formas de controle por ele exercidas, em especial sobre as filhas e a esposa. Destaca que entre ela e seu marido as coisas são diferentes, pois os dois têm voz na relação. Como os demais beneficiários, ela constrói uma visão negativa da unidade de conservação implementada na área, especialmente em função da negligência do Estado quanto às licenças de plantio, associando restrições de uso do território à falta de trabalho, sobretudo para os jovens. Demonstra também compreensão sobre o fato destes pertencerem a uma geração com expectativas e desejos diferentes, sobretudo no que diz respeito ao consumo. Assim como Noêmia, Carlos e a família de Armando, reconhece e reafirma seu papel como defensora de seu território, alegando que cuidar e conservar o meio em que vivem é inerente à vida de pessoas que vivem na natureza.

Apesar de tantas proximidades de ponto de vista, Dona Tuca centra grande parte de sua narrativa na valorização da produção local que ainda pode ser realizada. Respeitando - e criticando - a proibição da queima para a preparação da área de plantio, ela encontra outros caminhos para continuar produzindo. Apesar do termo agrofloresta já estar bem disseminado entre populações tradicionais da região graças às experiências realizadas na cidade - como no sítio Bela Vista, de propriedade de Clodoaldo, que produz em Sistemas Agroflorestais (SAF’s) ${ }^{275}$ - Dona Tuca não o utiliza. Entretanto, quando entramos em seu quintal, logo percebemos que é a lógica de integração e associação entre espécies que ela utiliza de forma eficiente. Sobre a definição de Sistemas Agroflorestais:

\footnotetext{
${ }^{275}$ http://www.mda.gov.br/sitemda/sites/sitemda/files/user_arquivos_64/Revista_Proter_totalmente_corrig
} ida.pdf Acesso em janeiro/2017. 
Sistemas agroflorestais são formas de uso ou manejo da terra, nos quais se combinam espécies arbóreas (frutíferas e/ou madeireiras) com cultivos agrícolas e/ou criação de animais, de forma simultânea ou em sequiência temporal e que promovem benefícios econômicos e ecológicos. Os sistemas agroflorestais ou agroflorestas apresentam como principais vantagens, frente a agricultura convencional, a fácil recuperação da fertilidade dos solos, o fornecimento de adubos verdes, o controle de ervas daninhas, entre outras coisas. ${ }^{276}$

No quintal de Dona Tuca encontramos café, cana, banana, abacaxi, mandioca, e outros produzidos de forma associada e diversificada em todo o entorno de sua casa. Segundo ela, só não é possível produzir ali “arroz, feijão e milho, isso não dá na goteira, não dá embaixo do mato". Também integrado ao quintal, existe um pequeno apiário que produz o suficiente para seu consumo e ocasionalmente para venda. Dona Tuca se orgulha de sua produção orgânica, pois esta reflete um cuidado com sua saúde e a dos demais, já que assim evita-se o consumo de alimentos avaliados por ela como envenenados. Além de produzi-los, Dona Tuca também conhece as mais diversas técnicas de beneficiamento desses alimentos, produzindo farinha, bijus, café torrado e moído, doces em compota, geleias, etc. Todos esses produtos eram semanalmente oferecidos na feira da cidade que ocorria aos sábados. Muitos moradores da cidade mencionavam a existência da feira da agricultura familiar e a figura de Dona Tuca. Apesar da feira ainda existir, os moradores do Santa Maria e do Taquari não participam mais. Em relação à feira e sua importância para a economia local, ela nos conta que:

Eu carregava os produtos em um caminhão, fazia as coisas todas para levar na
sexta feira. Dormia lá, e sábado trabalhava na feira. Tinha um caminhão pra
isso. Depois fiquei ruim da perna, parei e entrou outro prefeito que tirou o
caminhão e acabou a festa! Parei de levar as coisas, mas fiz as minhas
freguesias, né? E falei: "olha, eu parei com a feira, mas na hora que vocês
quiserem podem encomendar." Ontem mesmo, o meu genro ligou para
encomendar vinte reais de biju. Não tem dia marcado não. Na hora que der, eu
levo. E vendo café por encomenda, vendo biju... Até o mês passado eu vendia
arroz. Agora acabou. Vendo inhame, cará... Só que agora não está na época de
cará e inhame. Vendo abacaxi, geleia... de goiaba, de abacaxi, doce de
carambola, geleia de carambola... Tudo de compota.

A feira a que Dona Tuca se refere foi uma das experiências recentes mais benéficas vividas pela população no tocante aos projetos de desenvolvimento local. Segundo Carlos França e Noêmia, a feira garantia trabalho e renda para muitas famílias

${ }^{276}$ http://www.ciflorestas.com.br/texto.php?p=sistemas Acesso em setembro/2016. 
da região, pois permitia que a produção local fosse estimulada e vendida. Segundo Noêmia:

\begin{abstract}
Nessa época eu vinha trabalhar na feira aqui na cidade. Eu plantava lá no sítio e vinha vender aqui na feira que era no sábado. Eu vinha e vendia feijão, farinha que eu plantava lá. Nessa época a gente trabalhava com pedido de licença, que foi um tal de Joaquim, quer dizer, nem sei se é Joaquim mas é diretor lá de Santos. Só sei que o Marcelo conseguiu muitas licenças. E nós trabalhávamos porque nós tínhamos licença.
\end{abstract}

Segundo os colaboradores da RESEX Taquari, o que viabilizava a existência da feira era a permissão de plantio por meio das licenças. Além disso, existia um caminhão cedido pela prefeitura, que ficava sob posse da comunidade e semanalmente levava os produtos para serem expostos e vendidos na cidade. Segundo Carlos França, a mudança de gestão na prefeitura tirou o caminhão das mãos das famílias participantes da feira, inviabilizando a continuidade do projeto. Assim:

\begin{abstract}
Nós formamos uma associação e não chegamos a registrar ela, e eu tenho ata dela ainda. Só que a gente tinha o sindicato da agricultura familiar da Vale ${ }^{277}$, que dava muito apoio para nós. E também tínhamos o caminhão da prefeitura que vinha buscar a mercadoria.

Isso aí foi feito através de mim e do próprio prefeito. Eu juntei todas as comunidades e conversamos entre nós, de Taquari, Santa Maria, Rio das Minas, Rio Branco, Aroeira... A gente formou um grupo grande, e tinha mais de vinte pessoas que fazia a feira. E entramos em conversa com o prefeito, porque a gente pediu e foi uma promessa na campanha dele. Então a gente foi cobrar e ele cumpriu essa promessa. Durante os quatro anos dele foi excelente, a gente teve a feira normal, aí na hora que mudou de prefeito tiraram o caminhão.

Umas vinte famílias participavam da Feira. Todas elas produziam de tudo e vendiam de tudo.
\end{abstract}

As evidências apresentadas pelas narrativas de nossos colaboradores nos permitem compreender que eles são parte de uma comunidade voltada sobretudo para a produção agrícola. Poderíamos pensar que trata-se de uma vocação forjada na memória pela imagem de um passado de liberdade e abundância alimentícia propiciadas pela agricultura. Entretanto, a existência da feira em um passado bem recente demonstra que, para nossos colaboradores, esta é uma cultura ainda presente na região e que pode ser reavivada por meio de estímulos, tais como:

\footnotetext{
277 Sindicato Dos Trabalhadores da Agricultura Familiar do Vale do Ribeira e Litoral Sul. http://www.cnpjsaopaulo.com/s/empresa/sintravale/18700372000196 Acesso em janeiro/2017.
} 
- Materiais: O caminhão e a manutenção correta da estrada são elementos fundamentais para que a produção possa ser escoada para a cidade;

-Burocracia: A emissão de licenças é importante não apenas para garantir a legalidade das roças, como para encorajar os moradores a fazê-las sem medo de multas ou retaliações por parte do Estado ou da polícia ambiental. Também seria importante a obtenção do certificado de produção orgânica, o que ampliaria o mercado para esses produtores.

-Técnicas e educacionais: A introdução de novas técnicas de produção vinculadas às especifidades da região e das áreas de plantio pode ser estimulada por meio de trocas de saberes entre técnicos agroflorestais e populações tradicionais locais.

- Políticas: Carlos França vem tentando criar a associação do bairro e enfrenta diversas dificuldades, o que poderia fortalecer os laços políticos da comunidade e sua ação frente ao Estado, sobretudo em relação à Fundação Florestal. Segundo Ferreira, tais ações coletivas têm se mostrado como fatores mais importantes para o sucesso de iniciativas políticas voltadas para a proteção da biodiversidade do que as caraterísticas culturais dos usuários dos recursos naturais. ${ }^{278}$

A experiência de Dona Tuca também demonstra como a tradição cultural pode ser dinâmica e frequentemente reinventada em diferentes contextos. Diante das restrições ao plantio impostas pela legislação ambiental, e da sua idade já avançada, que inviabiliza seu deslocamento para áreas afastadas de roça como fazia antigamente, ela manteve sua produção em uma área pequena e vista como pouco adequada. No entanto, ela não apenas produz alimentos orgânicos, para os quais já existe um mercado novo e significativo, como aliou antigas técnicas de beneficiamento às máquinas novas, como o ralador de mandioca, o moedor de cana e o torrador de café elétricos. Dessa forma, sua vivência e criatividade nos permitem vislumbrar um encontro entre os saberes tradicionais e técnicas e melhoramentos atuais.

\footnotetext{
${ }^{278}$ FERREIRA, op.cit.p10
} 


\section{Considerações finais}

A pesquisa realizada nas unidades de conservação ambiental de uso sustentável RDS Itapanhapima e RESEX Taquari partiu das histórias de vida dos beneficiários destas unidades, excetuando-se Maria Aparecida Rangel, cuja narrativa nos parece fundamental para compreender o processo histórico e social da cidade de Cananeia e seus moradores. O processo de elaboração das narrativas e o trabalho de campo inerentes ao conjunto de procedimentos que caracterizam a história oral nos aproximaram do complexo debate socioambiental que envolve o cotidiano dos colaboradores deste estudo. Nesse sentido, o amplo debate que envolve a noção de populações tradicionais e sua permanência em unidades de conservação tem se mostrado uma arena de disputas teóricas e políticas que aproximam cada vez mais as ciências humanas dos debates ambientais. Trata-se de uma questão fundamental e ampla que abrange várias vertentes teóricas. Para alguns autores, as populações possuem uma maneira de interpretar e se relacionar com o mundo que os alça à condição de preservacionistas culturais, cujas técnicas de manejo e o profundo conhecimento sobre o meio que habitam estabelecem um estreito vínculo entre o modo vida e a conservação da biodiversidade. Um dos grandes expoentes dessa vertente é Antônio Carlos Diegues, cujo trabalho está associado à luta das populações tradicionais do Vale do Ribeira, em especial à organização da comunidade do Mandira, hoje reconhecida como quilombola, cujo território tradicional se insere na primeira reserva extrativista federal do estado de São Paulo. Diegues também contribuiu e influenciou o debate dos anos de 1990 em torno da elaboração do Sistema Nacional de Unidades de Conservação. Sua militância de dava sobretudo em prol da criação da Reserva de Desenvolvimento Sustentável (RDS) ${ }^{279}$, o que de fato ocorre com a promulgação desse conjunto de leis que sistematiza nacionalmente as normas e diretrizes legislativas que regem as unidades de conservação ambiental. Seu posicionamento é criticado por autores que questionam o caráter inerentemente conservacionista das populações tradicionais. Dentre esses, destacamos aqueles para quem a categoria populações tradicionais não constitui um conceito heurístico, mas sim ideológico. Tal conceito teria sido construído pelos movimentos sociais, que nos anos de 1980 começam a esboçar a aliança entre as demandas por reforma agrária e conservação ambiental por meio das lutas dos

\footnotetext{
${ }^{279}$ DIEGUES, Antônio Carlos, Da Reserva Ecológico-Cultural (REC) à Reserva de Desenvolvimento Sustentável (RDS): um pouco da história recente. Pesquisado em file:///C:/Users/Usuario/Desktop/RDSDiegues.pdf
} 
seringueiros amazônicos em prol da criação das reservas extrativistas. Para esses autores, o termo populações tradicionais muitas vezes é atribuído às variadas sociedades rurais para as quais a categoria "população tradicional" tornou-se um meio de garantir o acesso à terra. Dessa forma, o conceito deve ser aplicado de forma cautelosa, posto que pode "comprometer a autonomia e a qualidade de vida dessas populações e, de outro, a própria conservação ambiental". ${ }^{280}$ Adams $^{281}$ complementa que muitas dessas populações consideradas tradicionais são na verdade grupos cuja integração com os recursos naturais decorre da necessidade de sobrevivência, posto que são historicamente excluídos política e socialmente. Dessa forma, muitos dos estudos que relacionam seu modo de vida à conservação ambiental seriam de cunho político-ideológico com pouca precisão científica do ponto de vista da ecologia. Como parte desse debate, Cunha e Almeida ${ }^{282}$ sinalizam duas das principais críticas dirigidas às populações tradicionais: em primeiro lugar, nem todas as populações tradicionais são conservacionistas e, em segundo, as que hoje são podem ser tornar predatórias a partir da inserção no mercado. Para os autores, as populações tradicionais não podem ser vistas como naturalmente conservacionistas, posto que são sociedades dinâmicas e cuja identificação com o conceito, propositalmente abrangente, dá-se por um processo de autoconstituição que inclui o estabelecimento de regras de conservação. Dessa forma, eles podem ser vistos como neoconservacionistas sob a perspectiva de que os grupos inseridos na categoria “populações tradicionais" são sujeitos políticos dispostos a conferir substância ao conceito.

Em relação às populações tradicionais que colaboraram com este estudo, pudemos constatar que essas pessoas foram duplamente punidas, pois além de serem submetidas à violência da concentração de terras decorrente da ação de grileiros, vivenciaram a opressão do Estado por meio das restrições de uso e manejo dos recursos naturais de seu território impostas pela legislação ambiental. De suas narrativas emergem aspectos específicos relacionados à conservação ambiental, mas imersos em uma problemática antiga e atual do cenário político-social brasileiro: a questão agrária marcada pela concentração de terras e ausência de regularização fundiária. Dessa forma, as conquistas territoriais asseguradas pelos direitos fundiários diferenciados que reconhecem as

\footnotetext{
${ }^{280}$ VIANNA, op.cit.31.

${ }^{281}$ ADAMS, Cristina, As populações caiçaras e o mito do bom selvagem: a necessidade de uma nova abordagem interdisciplinar. Revista de Antropologia, São Paulo, USP, 2000, V. 43 nº 1.

${ }^{282}$ CUNHA, Manuela Carneiro da, ALMEIDA, Mauro W.B. Populações Tradicionais e Conservação Ambiental. In: Cultura com Aspas e outros ensaios. São Paulo: Cosac Naify, 2009 p.300
} 
populações tradicionais e seus territórios historicamente ocupados, é vista por autores como Little ${ }^{283}$ como parte da reforma agrária brasileira. Para alguns de nossos colaboradores, como Adelmo e Dirce, umas das conquistas trazidas pelas unidades de conservação sustentáveis foi a regularização de suas terras de forma a afastar o risco de invasões e grilagens. Além disso, as narrativas remetem a aspectos que reafirmam o compromisso ambiental, sendo grande parte das críticas dirigidas não ao uso sustentável do território, mas à ineficiência na forma de fazê-lo. Mostram-se, portanto, dispostos ao pacto social e ao seu papel como agentes locais de proteção ambiental, mas alegam necessitar de apoio para que possam construir relações de cunho conservacionista com o território que habitam. Ou seja, a rejeição à unidade de conservação não decorre apenas das restrições impostas, mas, sobretudo, pela forma unilateral e pouco participativa com que foram inseridos no projeto. Assim, se pretende-se exigir que tais populações consigam de fato tornar-se guardiãs de espaços de conservação ambiental, a parceria deve ser estabelecida de forma a considerar os conhecimentos e demandas dessas populações, que demonstram um grande potencial para o desenvolvimento de projetos sustentáveis.

Não pretendemos, portanto, concluir sobre o tema ou classificar nossos colaboradores como conservacionistas ambientais ou não. Mas concordamos com a posição de Dona Tuca que condena o fato de que as populações moradoras de áreas ambientalmente bem preservadas acabam por arcar com grande parte do ônus da destruição ambiental em larga escala causada pelo modo de produção capitalista e o uso desenfreado de recursos naturais que o caracteriza. Constituem, portanto, mais um dos muitos grupos afetados por situações de injustiça ambiental, atualmente cada vez mais frequentes.

${ }^{283}$ LITTLE, p.09 


\section{Bibliografia}

ADAMS, Cristina. Caiçaras na Mata Atlântica, pesquisa cientifica versus planejamento e gestão ambiental. São Paulo: Annablume/Fapesp, 2000.

As populações caiçaras e o mito do bom selvagem: a necessidade de uma nova abordagem interdisciplinar. Revista de Antropologia, São Paulo, USP, 2000, V. $43 n^{\circ} 1$.

ALMEIDA, Mauro W. Barbosa de Almeida. A Criação da Reserva Extrativista do Alto Juruá. Conflitos e Alternativas para Conservação. Departamento de Antropologia. Universidade Estadual de Campinas, agosto/1993.

ALMEIDA, Alfredo Wagner Berno de Almeida. Terras Tradicionalmente Ocupadas. Processos de Territorialização e Movimentos Sociais. Revista Brasileira Estudos Urbanos e Regionais, v.6, maio/2004.

AMARANTES, Caroline Bastos do. Reconhecimento Jurídico-Normativo das Populações Tradicionais Pelo Estado Brasileiro: Uma Revisão. Enciclopédia Biosfera, Centro Científico Conhecer- Goiânia, vol.7, nº 12, 2011.

ANDRELLO, Geraldo (org.). Rotas de Criação e Transformação. Narrativas de Origem dos Povos Indígenas do Rio Negro. São Paulo, Instituto Socioambiental; São Gabriel da Cachoeira, Amazonas, Federação das Organizações Indígenas do Rio Negro, 2012.

ARRUDA, Rinaldo. Populações 'Tradicionais e a proteção dos recursos naturais em Unidades de Conservação. In: Anais do Primeiro Congresso Brasileiro de Unidades de Conservação. Vol. 1, Conferências e Palestras, p. 262-276. Curitiba, Brasil, 1997.

ARRUTI, José Maurício Andion. A emergência dos "remanescentes": notas para o diálogo entre Indígenas e Quilombolas. Mana, vol.3, nº 2, Rio de Janeiro: 1997.

ATAIDE, Yara Dulce Bandeira de Ataide. Clamor do presente, história oral de famílias em busca da cidadania. São Paulo: Edições Loyola, 2002.

BAUMAN, Z. Identidade. Rio de Janeiro: Jorge Zahar Editor, 2005. Comunidade. Rio de Janeiro: Jorge Zahar Editor, 2005.

BARBOSA, Talita dos Santos, GUSSONATO, Leon, SUSUKI, Júlio César. Divergências Conceituais nas Políticas Públicas de Conservação Ambiental: O Caso da Comunidade de Peropava. Anais XVI Encontro Nacional de Geógrafos. Porto Alegre: 2010. 
BENJAMIN, Walter. O Narrador. In: Magia e técnica, arte e política. São Paulo. Ed. Brasiliense, vol. 01, 1987, pp. 197-221 (Obras Escolhidas).

BERNINI, Carina Inserra. A produção da natureza conservada na sociedade moderna: uma análise do Mosaico de Unidades de Conservação do Jacupiranga, Vale do Ribeira - SP. Dissertação (mestrado), Faculdade de Filosofia, Letras e Ciências Humanas. Universidade de São Paulo: 2010.

BIM, Ocimar José Batista. Mosaico do Jacupiranga - Vale do Ribeira. Conservação, conflitos e soluções socioambientais. Dissertação (mestrado). São Paulo: Faculdade de Filosofia, Letras e Ciências Humanas da Universidade de São Paulo, 2012.

BOSI, Ecléa. O tempo vivo da memória - Ensaios sobre psicologia social. São Paulo: Atelier Editorial, 2003.

Memória e sociedade: lembranças de velhos. São Paulo: Companhia das

Letras, 1994.

CALVIMONTES, Jorge. Bandidos na Serra do Mar: conflitos, estratégias e usos múltiplos dos recursos naturais na Mata Atlântica. Tese de doutorado, Instituto de Filosofia e Ciências Humanas - IFCH, Universidade de Campinas: 2013.

CANCLINI, Nestor Garcia. Culturas híbridas. 4ed. São Paulo: EDUSP, 2003.

CANDIDO, Antônio. Os parceiros do Rio Bonito. 9ed. São Paulo: Editora 34, 2001.

CARTA SÃO PAULO. Workshop sobre Populações e Parques. Instituto Florestal, 1994.

CERTEAU, Michel de, A invenção do cotidiano, 15ed., Petrópolis, RJ: Vozes, 2008.

CHIQUINHO, Cléber Rocha. Saberes Caiçaras - A cultura Caiçara na História de Cananéia. São Paulo: Páginas \& Letras, 2007.

CUNHA, Manuela Carneiro da, ALMEIDA, Mauro W. Barbosa de. Populações Indígenas, Povos Tradicionais e preservação na Amazônia. In: CAPOBIANCO, João P., R.et al (orgs). Biodiversidade na Amazônia Brasileira - Avaliação e Ações Prioritárias para a Conservação, Uso Sustentável e Repartição de Benefícios. São Paulo: Instituto Socioambiental e Estação Liberdade, 2001

Cultura com Aspas e outros ensaios. São Paulo: Cosac Naify, 2009

DEAN, Warren. A Ferro e Fogo. A História e a Devastação da Mata Atlântica Brasileira, São Paulo: Companhia das Letras, 1996.

DIEGUES, Antônio Carlos. Biodiversidade e Comunidades Tradicionais no Brasil. São Paulo: NUPAUB-USP, 1999. 
(org). Etnoconservação: novos rumos para a proteção da natureza nos trópicos. São Paulo: Hucitec/Nupaub, 2000.

Diversidade biológica e cultural no Complexo Estuarino

Lagunar de Iguape-Cananeia-Paranaguá. FFLCH-USP, NUPAUB-USP, São Paulo, 1991.

VIANA, Virgílio M. Viana. Comunidades tradicionais e manejo dos recursos Naturais da Mata Atlântica São Paulo. 2ed. São Paulo: Hucitec - Nupaub, 2004.

O mito moderno da natureza intocada, 5ed. São Paulo:

5ed. Hucitec-Nupaub, 2004.

PEREIRA, Bárbara Elisa. Conhecimento de Populações

Tradicionais como Possibilidade de Conservação da Natureza: Uma Reflexão Sobre a Perspectiva da Etnoconservação. Desenvolvimento e Meio Ambiente, n.22, p. 37-50. Editora UFPR: jul./dez.2010.

O Vale do Ribeira e Litoral de São Paulo: meio-ambiente, história e população. Relatório produzido para o CENPEC. Março/2007.

DUARTE, Mara Grazzoli, Conflitos Fundiários e a Questão Ambiental: Estudo de Caso do Mosaico de Unidades de Conservação do Jacupiranga. Revista Geográfica da América Central. Número especial, EGAL. Costa Rica: 2011.

FERNANDES-PINTO, E. As RESEX e RDS e a Política Nacional de Povos e Comunidades Tradicionais - Interfaces com a Etnobiologia e Etnoecologia - Resumo expandido apresentado no VII Simpósio Nacional de Etnobiologia e Etnoecologia (VII SBEE), Belém/Pará, dezembro de 2008.

FERREIRA, Marieta de Moraes, AMADO, Janaína. Usos e Abusos da História Oral. 8ed. Rio de Janeiro: Editora FGV, 2006.

FERREIRA, Lucia da Costa. Dimensões humanas da biodiversidade: mudanças sociais e conflitos em torno de áreas protegidas no Vale do Ribeira, SP, Brasil. In: Ambiente e Sociedade. Vol.7, $\mathrm{n}^{\mathrm{o}} 1,2004$.

FERREIRA, Maria Lucia, OLIVEIRA, Simone de, SIVIERO, Simone Vieira de Campos, SILVEIRA, Pedro Castelo Branco, OLIVEIRA, Vivian Gladys de, MENDES, Ana Beatriz Vianna, PINTO, Anaisa de Oliveira. Conflitos Sociais em Áreas Protegidas no Brasil: Moradores, Instituições e Ong's no Vale do Ribeira e Litoral Sul. SP, Revista Idéias, 2001.

FERRERO, Cínthia B. Entre a natureza e a cultura: a relação entre políticas públicas ambientais e o fandango de Iguape e Cananéia (SP). XVI Congresso da Associação Nacional de Pesquisa e Pós-graduação em Música (ANPPOM). Brasília, 2006. 
FURLAN, Sueli Angelo, MARINHO, Maurício de Alcântara. Gestão Compartilhada e Comunitária em Áreas Protegidas: Reflexões no Vale do Ribeira. Revista Geográfica da América Central, número especial. Costa Rica, 2011.

Florestas Culturais: Manejo sociocultural, territorialidades e sustentabilidade. Agrária, n. 3. São Paulo, 2006.

GADELHA, Crismere. Proibido trabalhar: problema socioambiental dos filhos da Ilha do Cardoso. Unicamp e IFCH: Campinas, 2008.

GALINDO-LEAL, Carlos, CÂMARA, Ibsen de Gusmão (ed.) / LAMAS, Edma Reis. Mata Atlântica: biodiversidade, ameaças e perspectivas. São Paulo : Fundação SOS Mata Atlântica - Belo Horizonte : Conservação Internacional, 2005.

GERHARDT, Clayton. Pesquisadores e suas táticas discursivas no debate sobre populações tradicionais e proteção à biodiversidade. Desenvolvimento e Meio Ambiente, n. 21, p. 43-67, jan./jun. Editora UFPR, 2010.

GOHN, Maria da Glória. Teoria dos Movimentos Sociais - Paradigmas clássicos e contemporâneos. São Paulo: Edições Loyola, 1997.

HALBWACHS, Maurice. A memória coletiva. São Paulo: Vértice, 1990.

HERCUliani, Sueli. Uma Proposta de Política para a Gestão de Conflitos: Populações Tradicionais em Áreas Protegidas de Uso Indireto. II Congreso de Parques y Otras Áreas Protegidas. Anais. Bariloche: Argentina, 2007.

IOKOI, Zilda M. G. Igreja e Camponeses: Teologia da Libertação e Movimentos Sociais no Campo - Brasil e Peru - 1964/1986. São Paulo: Hucitec, 1997.

JOUTARD, Philippe. Desafios à História Oral do século XXI. In: FERREIRA, Marieta de Moraes (org.). História Oral: desafios para o século XXI. Rio de Janeiro: Editora Fiocruz/Casa de Oswaldo Cruz/CPDOC - Fundação Getúlio Vargas: 2000

LABURTHE-TOLRA, Phillippe, WARNIER, Jean-Pierre. Etnologia e Antropologia. Petrópolis: Vozes, 2010.

LANDER, Edgardo. Ciências Sociais: Saberes Coloniais e Eurocêntricos. In: (org.). A Colonialidade do Saber: Eurocentrismo e Ciências Sociais - perspectivas latino-americanas. Buenos Aires: CLACSO, 2005.

LEFEBVRE, Henri. Perspectivas da sociologia rural. In: MARTINS, José de Souza (org.). Introdução Crítica à Sociologia Rural. 2ed. São Paulo: Hucitec, 1986, p.173.

LIMA, Rodrigo Araújo de, SUSUKI, Júlio César. Geografia da Oralidade - Um Resgate da Tradição da Roça no Quilombo do Mandira. 2012. 
LITTLE, Paul. Territórios sociais e povos tradicionais no Brasil: por uma antropologia da territorialidade. Série Antropologia n 322, p.32. Brasília: UnB, 2002.

LOZANO, Jorge Eduardo Aceve. La Historia Oral contemporânea uma mirada plural. In: Historia Oral: ensayosya aportes de investigación. México: Ciesas, 2000.

MAGDALENA, Bianca Cruz. Reza a Lenda. A Cultura Caiçara de Cananeia vivenciada no Bairro Rural de Santa Maria. Londrina: Idealiza Gráfica e Editora, 2008.

MARCÍLIO, Maria Luiza. Caiçara, Terra e população. 2ed. São Paulo: Edusp, 2006.

MARTINS, José de Souza. A sociabilidade do homem simples. 2ed. São Paulo: Contexto, 2008.

Expropriação e violência, a questão política no campo.

São Paulo: Editora Hucitec, 1980.

. Exclusão social e a Nova desigualdade. São Paulo:

Paulus, 1997.

. Os camponeses e a política no Brasil. Petrópolis: Vozes, 1981.

MEDEIROS, Rodrigo, ARAÚJO, Fábio França Silva. Dez anos do Sistema Nacional de Unidades de Conservação da Natureza: lições do passado, realizações presentes e perspectivas para o futuro. Brasília: MMA, 2011.

MEIHY, José Carlos Sebe Bom. Manual de História Oral. 5ed. São Paulo: Loyola, 2005 .

,HOLANDA, Fabíola. História Oral: como fazer, como pensar. São Paulo, Contexto, 2007.

. (Re) Introduzindo História Oral no Brasil. São Paulo: Xamã, 1996.

Canto de Morte Kaiowá - História Oral de Vida. São Paulo: Loyola, 1991.

RIBEIRO, Suzana L. Salgado. Guia Prático de História Oral: para empresas, universidades, famílias. São Paulo: Contexto, 2011

MONTENEGRO, Antônio Torres. História Oral e Memória, a cultura popular revisitada. São Paulo: Contexto, 2001. 
MORAES, Marilia Britto Rodrigues de. Área de Proteção Ambiental - APA como agência de desenvolvimento sustentável: APA Cananéia- Iguape- Peruíbe. São Paulo, 2001.

MOURÃO, Fernando Augusto Albuquerque Mourão. Os Pescadores do Litoral Sul: um estudo de sociologia diferencial. São Paulo: Hucitec/NUPAUB/CEC, 2003.

Mussolini, Gioconda. Ensaios de Antropologia Indígena e Caiçara. Rio de Janeiro: Paz e Terra, 1980

NEDER, Ricardo Toledo. Crise Socioambiental, Estado e Sociedade Civil no Brasil (1982-1998). São Paulo: Annablume/FAPESP, 2002.

OLMOS, Fabio. Populações Tradicionais e Biodiversidade. http://www.oeco.org.br/colunas/fabio-olmos/21088-populacoes-tradicionais-e-abiodiversidade/ Acesso em fevereiro/2017.

Plano de Manejo, Parque Estadual da Ilha do Cardoso, Cooperação Financeira Brasil Alemanha Kreditanstalt für Wiederaufbau - KfW, 1995-2002.

Plano de Manejo, Reserva Extrativista do Mandira, 2010.

Plano de uso Reserva Extrativista do Taquari, 2010

Plano de uso Reserva Extrativista da Ilha do Tumba, 2010

Plano de uso Reserva de Desenvolvimento Sustentável do Itapanhapima, 2010

Plano de Ação, Mosaico do Jacupiranga, 2008.

RANGEL, Katia Souza. De Bairro Rural a Território Quilombola: Um estudo da Comunidade do Mandira. Dissertação (mestrado), Universidade de São Paulo, 2011.

Relatório Técnico-científico sobre os remanescentes da Comunidade de Quilombo de São Pedro, no Vale do Ribeira/Itesp. São Paulo: 1998.

ROCHA, Ana Flavia (org). A Defesa dos Direitos Socioambientais no Judiciário. São Paulo: Instituto Socioambiental, 2003.

SALES, R.J.R, MOREIRA, A.C.C. Reservas Extrativistas no Complexo EstuarinoLagunar de Iguape e Cananeia - domínio Mata Atlântica. Série documentos e relatórios de pesquisa n $^{\circ} 22$. São Paulo: NUPAUB, 1996.

SANTOS, Boaventura de Sousa MENESES, Maria Paula. (Orgs.) Epistemologias do Sul. São Paulo: Editora Cortez, 2010.

SANCHES, Rosely Alvim. Caiçaras e a estação ecológica de Juréia- Itatins, litoral sul de São Paulo. São Paulo: ANNABLUME/Fapesp, 2004. 
SANTILLI, Juliana. Socioambientalismo e novos direitos. São Paulo: Peirópolis,2005.

SARLO, Beatriz. Tempo Passado, Cultura da Memória e Guinada Subjetiva. São

Paulo: Companhia das Letras, 2005.

SEMPRINI, Andrea. Multiculturalismo. Bauru: EDUSC, 1999.

SILVA, Simone Resende da. Comunidades Quilombolas e a Política Ambiental e Territorial na Mata Atlântica. São Paulo: Geografia em Questão, v.05, 2012.

SILVA, André Luiz Ferreira. Reservas de Desenvolvimento Sustentável (RDS) e Reservas Extrativistas (RESEX) no Vale do Ribeira: Inovação ou Outra Forma de Fazer as Mesmas Coisas em Territórios Tradicionais no Estado de São Paulo? In: V Encontro Nacional da Anppas. Florianópolis, 2010.

SILVA, Fabio. Terra de Quilombo, arqueologia da resistência e etnoarqueologia no território Mandira, munícipio de Cananéia-SP. Dissertação (mestrado). Museu de Arqueologia e Etnologia, Universidade de São Paulo, 2012.

SNUC. Sistema Nacional de Unidades de Conservação. Reserva da Biosfera da Mata Atlântica. Caderno 18. São Paulo: 2000.

SÉRIE CADERNOS DA

RESERVA DA BIOSFERA. Número 18: Conselho Nacional da Reserva da Biosfera da Mata Atlântica, 2000.

TABARELlI, Marcelo, PINTO, Luiz Paulo, CARDOSO DA SILVA, José Maria, COSTA, Cláudia Maria Rocha. Espécies ameaçadas e planejamento da conservação. In: Mata Atlântica: biodiversidade, ameaças e perspectiva, 2005.

TAYRA, Flavio. Subdesenvolvimento e Sustentabilidade: o caso do Vale do Ribeira (SP). $\quad$ http://www.registro.unesp.br/sites/museu/basededados/arquivos/00000307.pdf Acesso em janeiro/2017.

TATTO, Nilto, SANTOS, Kátia Pacheco (ed.). Agenda socioambiental de comunidades quilombolas do Vale do Ribeira. São Paulo: Instituto Socioambiental, 2008.

THOMPSON, Paul. A Voz do Passado. 2ed. São Paulo: Paz e Terra, 1998.

VALENTIN, Agnaldo. Uma civilização do arroz, agricultura, comércio e substência no Vale do Ribeira. Tese de doutorado defendida na Faculdade de Filosofia, Letras e Ciências Humanas. São Paulo: Universidade de São Paulo, 2006.

VIANNA, Lucila Pinsard. De invisíveis a Protagonistas: populações tradicionais e unidades de conservação. São Paulo: Annablume/Fapesp, 2008. 
WARNIER, Jean-Pierre. A mundialização da cultura. 2ed. Bauru: EDUSC, 2000.

WALLERSTEIN, Immanuel. O Universalismo Europeu - a retórica do poder. São Paulo: Boitempo Editorial, 2007.

\section{Sites consultados}

http://www.mabnacional.org.br/noticia/guerra-no-vale-do-ribeira-contra-uma-hidreltrica Acesso em janeiro/2015.

http://www.conservation.org.br/publicacoes/files/CapituloVIIIEspeciesameacadaseplan ejamentodaconservacao.pdf Acesso em fevereiro/2017.

http://www.camara.gov.br/sileg/integras/566305.pdf PROJETO DE LEI No /08. Autor: Deputado IVAN VALENTE. Declara como Patrimônio Histórico, Cultural e Ambiental do Brasil o rio Ribeira de Iguape e dá outras providências. Acesso em dexembro/2016.

http://amp-pr.jusbrasil.com.br/noticias/253076/vale-do-ribeira-tenta-acabar-compobreza-cronica Acesso em fevereiro/2017

http://www.planalto.gov.br/ccivil_03/_ato2007-2010/2007/decreto/d6040.htm Acesso em março/2017.

http://www.caritas.org/es/dondeestamos/europa/irlanda/ Acesso em fevereiro/2016.

http://www.mundoamazonia.com.br/arquivos/conhecimento-tradicional-contribui-paranovo-metodo-de-pesquisa-para-busca-e-captura-de-pacas-na-amazonia-2/ Acesso em outubro/2016.

http://www.oocities.org/gerabrasil/artigo_reproduc_pacas.html Acesso em outubro/2016.

http://nomeiodopovo.blogspot.com.br/2011_03_01_archive.html Acesso em outubro/2016.

http://www.bioclimatico.com.br/pdf/entrevistas/SOS_HV007_\%20PadreJoaoXXX.pdf Acesso em outubro/2016.

http://www.planalto.gov.br/ccivil_03/leis/L9985.htm Acesso em fevereiro/2017.

http://www.planalto.gov.br/ccivil_03/_ato2007-2010/2007/decreto/d6040.htm Acesso em setembro/2016.

http://www.al.sp.gov.br/norma/?id=76411 Acesso em fevereiro/2017.

http://www.planalto.gov.br/ccivil_03/leis/L9985.htm Capítulo III, artigo 7. Acesso em janeiro/2017. 
http://www.ambiente.sp.gov.br/2017/02/20/mosaico-do-jacupiranga-mojac-completanove-anos/ Acesso em março/2017.

http://www.incra.gov.br/oqueegrilagem Acesso em dezembro/2015.

http://www.ambiente.sp.gov.br/ilha-do-cardoso/ Acesso em julho/2016.

http://www.bioclimatico.com.br/pdf/entrevistas/SOS_HV013_\%20AntonioTeleginski.p df Acesso em fevereiro/2015.

http://www.museudapessoa.net/pt/conteudo/pessoa/ezequiel-de-oliveira-24375 Acesso em maio/2016.

http://ww3.panaftosa.org.br/Comp/MAPA/5321322.pdf Acesso em janeiro/2017.

http://sao-paulo.estadao.com.br/noticias/geral,tj-ve-corrupcao-em-hotel-apos-16-anosimp-, 1030912 Acesso em janeiro/2017.

http://www.arquivoestado.sp.gov.br/uploads/acervo/textual/deops/prontuarios/BR_SP APESP_DEOPS_SAN_P003676_01.pdf Acesso em maio/2016.

www.sosma.org.br Acesso em janeiro/2017.

http://www.bioclimatico.com.br/ Acesso em março/2017.

http://www.diocesedesantos.com.br Acesso em fevereiro/2016.

http://cidadeilustre.blogspot.com.br/2013/05/o-caso-do-hotel-gloria-estadao.html Acesso em março/2017.

http://www.icmbio.gov.br/cairucu/quem-somos/perguntas-frequentes/20-perguntasfrequentes/73-qual-a-diferenca-entre-ibama-e-icmbio.html Acesso em dezembro/2016.

http://www.cetesb.sp.gov.br Acesso em dezembro/2016.

http://www.ambiente.sp.gov.br/parque-lagamar-de-cananeia/informacoes-ao-usuario/ Acesso dezembro/2016.

http://www2.camara.leg.br/legin/fed/lei/1980-1987/lei-6902-27-abril-1981-371587publicacaooriginal-1-pl.html Acesso em setembro/2016.

https://documentacao.socioambiental.org/ato_normativo/UC/1561_20140806_151342.p df Acesso em setembro/2016.

http://www.socioambiental.org/inst/esp/consulta_previa/?q=convencao-169-da-oit-nobrasil/a-convencao-169-da-oit Acesso em fevereiro/2017.

http://www.planalto.gov.br/ccivil_03/_ato2007-2010/2007/decreto/d6040.htm Acesso em março/2017. 
http://www.cnpjsaopaulo.com/s/empresa/sintravale/18700372000196 Acesso em janeiro/2017.

http://www.al.sp.gov.br/repositorio/legislacao/decreto.lei.complementar/1969/decreto.le i.complementar-4-01.09.1969.html Acesso em janeiro/2017.

http://noticiasdecananeia.com.br/noticia/366/protesto-acaba-em-tumulto-em-frente-aprefeitura-de-cananeia-virando-caso-de-policia- Acesso em janeiro/2017.

http://g1.globo.com/sp/santos-regiao/noticia/moradores-de-cananeia-sp-fazem-protestopor-melhorias-no-acesso-ao-bairro-ariri.ghtml Acesso em fevereiro/2017.

http://www.rbma.org.br/mab/unesco_01_oprograma.asp Acesso em dezembro/2016.

http://www.rbma.org.br/rbma/pdf/caderno_37.pdf Acesso em dezembro/2016.

http://arquivos.ambiente.sp.gov.br/cpla/2011/05/2016-icms-valores-repassados.pdf

Acesso em fevereiro/2017.

http://coloniaz9depescadores.blogspot.com.br/2013/04/mercado-municipal-decananeia.html Acesso em março/2017.

http://www.redecananeia.org.br/COLONIA-DE-PESCADORES Acesso em setembro/2016.

http://www.tnc.org.br Acesso em outubro de 2016

http://www.icmbio.gov.br/cepsul/images/stories/artes_de_pesca/artesanal/arrasto/geriva 1.pdf Acesso em fevereiro/2017.

http://canoacaicarabrasil.blogspot.com.br/ Acesso em março/2017.

http://www.agricultura.gov.br/comunicacao/noticias/2010/07/especial-sif-atesta-

qualidade-de-produtos-de-origem-animal Acesso em dezembro/2016.

http://revistagloborural.globo.com/Revista/Common/0,ERT148963-18283,00.html

Acesso em março/2017.

http://www1.folha.uol.com.br/fsp/dinheiro/fi2110200329.htm Acesso em dezembro/2016.

http://www.etecagricoladeiguape.com.br/projetousp/Sub6.php Acesso em fevereiro/2017.

http://www.mda.gov.br/sitemda/sites/sitemda/files/user_arquivos_64/Revista_Proter_totalmente corrigida.pdf Acesso em janeiro/2017.

http://www.ciflorestas.com.br/texto.php?p=sistemas Acesso em setembro/2016. 
